\title{
RELEVANT RESEARCH OF HISTORICAL SCIENCES
}

Monograph

$\underbrace{1256}_{\text {LIHA-PRES }} \begin{aligned} & \text { Lviv-Toruń } \\ & \text { Liha-Pres } \\ & 2019\end{aligned}$ 


\section{Reviewers:}

Prof. nadzw., dr hab. Stanistaw Kunikowski, Rektor of Cuiavian University in Wloclawek (Republic of Poland);

Prof. dr hab. Joanna Marszalek-Kawa, Uniwersytet Mikołaja Kopernika w Toruniu / Nicolaus Copernicus University (Republic of Poland).

Relevant research of historical sciences : collective monograph / V. M. Andreyev, R. V. Bey, I. S. Borodai, H. Z. Hrytsenko, etc. - Lviv-Toruń : Liha-Pres, 2019. - 300 s.

Liha-Pres is an international publishing house which belongs to the category „C" according to the classification of Research School for Socio-Economic and Natural Sciences of the Environment (SENSE) [isn: 3943, 1705, 1704, 1703, 1702, 1701; prefixMetCode: 978966397]. Official website - www.sense.nl. 


\section{CONTENTS}

VIKTOR PETROV'S “EPOCH THEORY”:

THE PHENOMENON IN THE NATIONAL HISTORIOGRAPHY

OF THE MIDDLE TWENTIETH CENTURY

Andreyev V. M.

DEVELOPMENT OF HYGIENE OF FARM ANIMALS

IN UKRAINE (THE SECOND HALF OF THE 19th EARLY 21th CENTURIES)

Bey R. V.

FORMATION AND DEVELOPMENT OF THE SCIENCE

OF ANIMAL FARM FEEDING (THE SECOND HALF OF 19th EARLY OF THE 21st CENTURIES)

Borodai I. S.

THE BELARUSIAN-UKRAINIAN SOCIO-CULTURAL

RELATIONS IN THE SECOND HALF OF XIX ${ }^{\mathrm{TH}}{ }_{-}$

EARLY XX ${ }^{\text {th }}$ CENTURY

Hrytsenko H. Z.

PECULIARITIES OF SCIENTIFIC SCHOOLS' ACTIVITY

DIRECTIONS TO IMPROVE AGROECOSYSTEMS IN FOREST-

STEPPE OF UKRAINE (SECOND HALF OF THE XIXth -

BEGINNING OF THE XXIst CENTURIES)

Kovalenko N. P.

STAGES OF POULTRY FARMING DEVELOPMENT IN

UKRAINE OF THE SECOND HALF OF 20th - AT THE BEGINING

OF THE 21st CENTURIES

Melnyk V. V.

AGRARIAN SCIENCE DEVELOPMENT TO INCREASE THE EFFICIENCY OF IMPLEMENTATION OF ORGANIC AGRICULTURE TECHNOLOGY IN UKRAINE (1990-2015)

Orekhivskyi V. D.

CENTRALIZATION OF AGRICULTURAL RESEARCH CASE IN UKRAINE IN THE FIELD OF POLITICAL AND SOCIAL-ECONOMIC CONDITIONS (20-30th OF XX CENTURY)

Shchebetyuk N. B. 
MONASTERIES OF WESTERN DIOCESES OF KYIV UNION

METROPOLIYA (90th YEARS OF XVII - 90th YEARS

OF XVIII CENTURES): JURISDICTIONAL CONVERSIONS

Stetsyk Y. O.

RUSSIAN-UKRAINIAN WAR 2014-2019 YEARS

AS THE DECISIVE STAGE OF THE STRUGGLE

FOR THE UKRAINIAN INDEPENDENT STATE

Sytnyk O. M.

PERCEPTION OF MYKHAILO HRUSHEVSKY'S WORKS

DURING INTERWAR PERIOD

Telvak V.P. 201

HISTORY OF AGRICULTURE IN UKRAINE DURING

THE INTEGRATION OF STATE REGULATION SYSTEMS

Vergunov V. A. 220

THE INTRODUCTION OF STATISTICAL RESEARCH

BY PROVINCIAL AND DISTRICT ZEMSTVOS

FOR AGRARIAN BRANCHES

Vergunova I. M

STATE ARCHIVE OF LVIV OBLAST:

SOURCE POTENTIAL FOR THE HISTORY

OF UKRAINIAN CULTURE

Yanyshyn B. M.

POLITICIZATION OF HISTORY: TERMS, METHODS, SIGNIFICANCE

Yaremchuk V.P. 280 
DOI https://doi.org/10.36059/978-966-397-100-1/5-30

\section{VIKTOR PETROV'S “EPOCH THEORY": THE PHENOMENON IN THE NATIONAL HISTORIOGRAPHY OF THE MIDDLE TWENTIETH CENTURY}

\section{Andreyev V. M.}

\section{INTRODUCTION}

Viktor Platonovych Petrov (pseudonyms - V. Ber, Borys Verigo, V. Domontovych, V. Plyat and other; 1894-1969) was one of the brightest Ukrainian intellectuals of his time - an outstanding scientist of encyclopedic erudition (historian, anthropologist, archaeologist, literary scholar, linguist, folklorist, and philosopher), organizer of science, public figure and writer of the circle of neoclassicists and Soviet intelligence agent.

V. Petrov was considered to be an outstanding, original and even brilliant philosopher and scientist at the Ukrainian literary and academic circles of «golden age» of Ukrainian humanities of 1920-s and «immigrant renaissance» of the second half of the 1940-s. However, due to various circumstances and life collisions, his multifaceted scientific potential was «deleted» from the intellectual space of the USSR and Ukrainian diaspora, underestimated and forgotten for a long time. So today V. Petrov remains little-known not only in the world, but also at home.

Almost all his life, since 1919, excluding a forced interruption in 1942-1956 s., V. Petrov devoted himself to the Academy of Sciences of Ukraine. He was one of the first scientists of All-Ukrainian Academy of Sciences, actively and productive working in various academic institutions. In 1919-1920s V. Petrov was a Secretary of the Commission for Ukrainian historical dictionary making. Since January 1920 he started working as a researcher and later as a secretary (1923-1927) and a head (1927-1933) of Ethnographic Commission attached to All-Ukrainian Academy of Sciences, edited various publications of the institution. In 1927 the Russian Geographical Society, recognizing the merits of V. Petrov in organization of ethnographic science in Ukraine, vigorous activity in studying of folk culture and everyday life, awarded him a silver medal. In 1928 the scientist was elected as an existing member of this society. In 1930 the scientist 
took a degree of Doctor of Philology for the monograph about P. Kulish. Since 1933 V. Petrov held the position of the researcher, and since 1939 he was a head of the sector of pre-feudal and feudal archeology of the Union of Institutions of Material Culture (the Institute of History of Material Culture since 1934, which was later reorganized into the Institute of Archaeology attached to the Academy of Sciences of the Ukrainian Soviet Socialist Republic (IA AS USSR). Since February 1941 the scientist became a director of the newly established Institute of Ukrainian Folklore attached to the Academy of Sciences of the USSR. This period of his research activity is presented by a fairly significant scientific achievements (especially in the field of ethnography) - more than 100 works.

During the Soviet-German War Viktor Platonovych served in the Red Army - he was a reconnaissance man. In 1945-1949s., performing the tasks of the Soviet reconnaissance, he worked among Ukrainian emigration in Bavaria. He was one of the founders of Ukrainian Art Movement (UAM), Ukrainian Free Academy of Sciences, editor of periodical literature, teacher at institutions of higher education of Ukrainian emigration (Ukrainian Free University, Theological Academy of Ukrainian Autocephalous Orthodox Church, Ukrainian Technical and Economic Institution, etc.), worked a lot in the field of science. Officially V. Petrov was employed by the Ministry of Foreign Trade of the USSR as a researcher till 1950. In 1950-1956s., after mysterious return from Germany, the scientist worked as a researcher at the Institute of History of Material Culture of the USSR in Moscow, and since December 1956 until his death he worked at the Institute of Archaeology attached to the Academy of Sciences of the USSR.

V. Petrov's top achievement as an intellectual and versatile scholar is his "epoch theory". The thinker suggested an original conception of ancient history of Ukraine, which became an important theoretical and practical contribution to Ukrainian historiography. His concept was based on the discrete, cyclical vision of the historical process and was in the line with the main trends of European historiosophical thought of 1920-1940, it was directly in the context of intellectual ideasof M. Berdyaev, V. Velflin, N. Danilevsky, A. J. Toynbee, S. Freud, M. Foucault, M. Khvylovy, D. Chyzhevsky, F. Schmitt, O. Spengler and the existentialists.

On the basis of the «epoch theory» the scientist developed a scheme of ancient history of Ukraine («prehistory of Ukrainian people») and a 
scheme of ethnogenesis of Ukrainian people as a part of European history. This opened a new way for the development of national historical science and could cause a «revolution» in Ukrainian historical writing. However, intellectual initiative of the scientist was not accepted by his contemporaries and to this day it remains outside the main directions of theoretical and practical search of historians.

This article deals with the phenomenon of Victor Petrov in the national historiography of the twentieth century. Although the polymath was working for decades within the framework of the Soviet historical science and its academic institutions and Marxist discourse played a certain role in its formation, in my opinion, we should talk about alternativeness of views of V. Petrov concerning Marxism, which was prevailing in the Soviet science. The Marxist conception as an explanatory model of the historical process and methodological tool of scientific research did not satisfy the scientist.

There are several stages in the formation of historical conception of V. Petrov. However, it was not enunciated in a distinct and final way due to different reasons.

\section{Familiarity and Creative Mastering of European, Russian and Ukrainian Philosophical and Historiosophical Thought}

The first stage -1910 -th - early 1930-th. - familiarity and creative mastering of European, Russian and Ukrainian philosophical and historiosophical thought (G. Lotze, G. Hegel, V. Velflin, N. Danilevsky, O. Spengler, F. Schmitt, M. Khvylovy, early existentialists, classical scholars of Marxism and others).

In the 1920s the ideas of German philosopher O. Spengler were known in Ukraine, they became popular in the forefront of cataclysms of World War I and post-war poverty. He was sympathized, admired and even for some time there was an intellectual fashion for O. Spengler. «The Decline of the West» was repeatedly discussed on the pages of Soviet publications ${ }^{1}$. Therefore naturally, his concept was embraced and transformed in the works of a number of Ukrainian intellectuals.

Ukrainian national communists $M$. Khvylovy created his own historical and philosophical conception of culture (Asian Renaissance

\footnotetext{
1 Базаров В. О. Шпенглер и его критики. Красная Новь. 1922. № 2. Ст. 212-225; Пятаков Г. Философия современного империализма (Этюд о Шпенглере). Красная новь. 1922. № 3. Ст. 182-197.
} 
theory) based on the theories of local civilizations of N. Danilevsky, O. Spengler and Marxism. It was formulated in the context of the social and literary discussions in the Soviet Ukraine of mid-1920-th, in the center of which stood the prospects of development of Ukrainian culture. The last, seventh chapter of the pamphlet «Ukraine or Little Russia?» (1926) is devoted to the presentation of the conceptual foundations of the theory of the Asian Renaissance ${ }^{2}$. M. Khvylovy took the original thesis that every nation is going through childhood, cultural and civilizational stages; the latter is the final chord of every culture and the beginning of its end. But historical types of cultures are not locked in a «spontaneous frames ... that come under the sign of their fate» (as presented in the concepts of «idealistic intuitionalism» of N. Danilevsky and O. Spengler), but framed in the patriarchal, feudal, bourgeois and proletarian time. Every single one of these types is original, but the element of «natural inheritance» is still compulsive.

According to the ideas expressed by M. Khvylovy, almost all cultures of patriarchal period (Mycenaean, Indian, Egyptian, Babylonian, Arabic) were formed by peoples who inhabited the territory of Asia, or were geographically adjacent to it. The «Human material» of Asia exhausted its «creative energy», solving problems of patriarchal period, and feudal type manifested itself on the European territory. The energy of the population of Europe, which they were accumulating for centuries, was enough to create a culture of the third type - the bourgeois type. At the present stage the bourgeois type dies, Western society is in decline and therefore new proletarian cultural-historical type is being created on the territory of Asia.

This cultural-historical type that M. Khvylovy calls «Asian Renaissance» will be determined by high classical erudition and will be based on the achievements of Asian as well as European cultures. One of the conditions of Asian Renaissance is the presence of Bolshevik state model. Since Ukraine is situated on the border of Europe and Asia and has the ability to use energy potential of one as well as the other, it should be at the forefront of the fourth cultural-historical type.

The views of M. Khvylovy had considerable attention in the Soviet Ukraine; he entered the national history not only as a writer, literary figure, but as a representative of the original philosophical thought as well ${ }^{3}$.

\footnotetext{
2 Хвильовий М. Україна чи Малоросія? Хвильовий М. Санаторійна зона: оповідання, новели, повісті, памфлети. Харків: Фоліо, 2008. Ст. 334-381.

${ }^{3}$ Горський В. С. Історія української філософії. 3-е вид.. К.: Наукова думка, 1997. Ст. 255-258.
} 
It should be noted that the concept of M. Khvylovy was presented in a popular form, did not have justified terminology, it called for discussion to a greater extent than it was giving answers. The Asian Renaissance theory concerned the problems associated with philosophical comprehension of Ukrainian national idea directly, for the author it actedas means of addressing spiritual progress of Ukrainian people through the dilemma «Russia - Europe», but it did not play an independent role. V. Petrov thought highly of the pamphlets of M. Khvylovy and considered him to be «a true European», who meant not «Europe in general», not «the machinery», not «the proletariat», but a «western intellectual», a high type of spiritual culture ${ }^{4}$.

V. Petrov as a direct participant of literary and cultural debates during 1925-1928 was certainly familiar with the research of O. Spengler and its reception in the works of $\mathrm{M}$. Khvylovy. However, it should be noted that the scientist could independently come to an understanding of discontinuity of the historical process through the studies in the field of German philosophy, in particular -the works of R.G. Lotze, who developed the ideas that were close to the doctrine of monads of G.W. Leibniz. It is known that the theory of local civilizations emerged in the context of the philosophical tradition of Leibniz in Germany (civilization - a kind of historical process monads) ${ }^{5}$.

However, in 1919, a famous Russian art historian and archaeologist F. Schmitt, whose life for quite a long time was associated with Ukraine (Kharkiv, Kyiv), set out his ideas of cyclical development of art («Laws of history» (1916), «Art - its psychology, its stylistics, its evolution» $(1919))^{6}$. There upon in due course time he was often compared to A. J. Toynbee and called a «Russian Spengler» ${ }^{7}$. In his memoirs V. Petrov noted that a lecture of Fyodor Ivanovych delivered in Kiev in 1919 imposed a strong impression on him.

\footnotetext{
4 Петров В. Діячі української культури (1920-1940рр.) - жертви більшовицького терору. К.: Воскресіння, 1992. Ст. 41.

5 Зашкільняк Л. Методологія історії від давнини до сучасності. Львів: Львів. держ. ун-т ім. І. Франка, 1999. Ст. 172-175; Ионов И. Н. Теория цивилизаций. Этапы становления. Новая $и$ новейшая история. 1994. № 4/5. Ст. 33-50; Ионов И. Н. Рождение теории локальных цивилизаций и смена научных парадигм. Образы историографии. М., 2001. Ст. 59-84; Космина В. Г. Проблеми методології цивілізаційного аналізу історичного процесу. Запоріжжя: Запоріз. нац. ун-т, 2011. 310 ст.; Репина Л. П., Зверева В.В., Парамонова М.Ю. История исторического знания. М.: Дрофа, 2004. Ст. 217-220; Яковенко Н. Вступ до історії. К.: Критика, 2007. Ст. 253 тощо.

${ }^{6}$ Шмит Ф. И. Законы истории. Введение к всеобщей истории искусств. Харьков, 1916. 198 с.; Шмит Ф. И. Искусство - его психология, его стилистика, его эволюция. Харьков, 1919. 328 ст.

${ }^{7}$ Михайловский И. Б. Архитектурные ордера. М, 1925. Ст. 25.
} 
Similar thoughts on the discreteness of art history were also expressed by a Swiss Scientist G. Wolfflin ${ }^{8}$ (his book «Renaissance and Baroque») was translated into Russian in 1913 and also had a considerable impact on V. Petrov - a student of Kiev University $)^{9}$.

To the factors forming historiosophical views of $\mathrm{V}$. Petrov a modern researcher of his life and work V. Bryukhovetsky also joins the influence of his father's works - the works of Platon Petrov on the history of the church and prominent representatives of the so-called «Kiev philosophical circles» of the first decades of the twentieth century (M. Berdyaev, A. Gilyarov, V. Zenkovsky, Lev Shestov, D. Chyzhevsky) ${ }^{10}$.

Since the 1920s V. Petrov fruit fully worked in the field of history of philosophy, methodology of different humanities, history and theory of culture, he became acquainted with classical and modern philosophical systems, approbated them in different subject areas of historical research. Professional skills of V. Petrov allowed him to realize himself in specific historical, as well as theoretical studies.

During the 1930s the scientist was working within the limits of Marxist methodology and Marrism in the field of history of material culture and formed his own perception of objective laws of historical development of Eastern Europe ${ }^{11}$.

\section{Formation of V. Petrov's Historiosophical Views and His Historical Concept's Basis}

The second stage - the first half of 1940-s - attempts to present ideas in popular scientific and artistic works (during the administration of exploratory mission on the territory of the occupied Ukraine). The first fragmentary attempts to express their views on the history as the process of changing of epochs was carried out by the scientist in 1942 on the pages of literary magazine «Ukrainian sowing» in the article «The Goths in Ukraine and the culture of fields graves» (characteristics of ancient period on Ukrainian territory) and in the novel «Without soil»» ${ }^{12}$.

8 Вёльфлин Г. Ренессанс и барокко. [пер. с нем. Е. Г. Лундберга]. СПб.: Азбука-классика, 2004. 288 ст.

9 Домонтович В. Болотяна Лукроза. Київькі неокласики. К.: Факт, 2003. Ст. 295.

${ }^{10}$ Брюховецький В. Віктор Петров: верхи долі - верхи і долі. К.: Темпора, 2013. Ст. 33-35.

11 Андрєєв В. М. Віктор Петров: Нариси інтелектуальної біографії вченого : монографія. Дніпропетровськ: Герда, 2012. Ст. 91-106.

12 Домонтович В. Без грунту. Украӥнський засів. Х., 1942. Чис. 2. Ст. 30-57; Домонтович В. Без грунту. Продовження. Украӥнський засів. Х., 1943. Чис. 4. Ст. 49-71; Петров В. Готи на Україні та культура полів поховань. Український засів. Х., 1942. Чис. 1. Ст. 61-65. 
The third stage - the second half of 1940-s - historiosophical execution of principles of "epoch theory", its application to the understanding of European history, and an attempt to put the theory into historical specificity of ancient history of Ukraine. Formation of conception of $\mathrm{V}$. Petrov took place during his presence in the Western zones of occupation in Germany in a closed environment of Ukrainian intellectual elite in emigration.

The main socio-cultural factors that influenced V. Petrov's historiosophical understanding of the basic laws of historical process were the conditions of post-war ruins, ideological crisis of West European society, inability of the existing concepts to explain the historical reality of the totalitarian era, the appeal of European public opinion to cyclic theories and concepts in search of a way out of the cognitive crisis. Sharp society's reaction to the atomic bombings of 1945, his own intellectual experience, rueful feelings about the fate of Ukrainian and European culture, about the future of the world and humanity resulted in humanistic character of philosophical views of V. Petrov; moral values have precedence over the technical progress, the scientist appeals to Christianity.

In the second half of 1940-san outstanding Ukrainian philosopher and scientist D. Chyzhevsky works on the theory of cultural-historical epochs in the history of art. As far back as 1920-s he was schooled by European philosophic thought, the scientist listened to the lectures of K. Jaspers, E. Husserl, M. Heidegger and others, but he did not become a supporter of a certain school. In post-war Germany, he, like other members of the second wave of Ukrainian immigration appeared in the close sociocultural, organizational and scientific contact with the intellectual elite of the Third Wave ${ }^{13}$. The fruitful scientific collaboration of D. Chyzhevsky and V. Petrov inter alia, manifested on the background of literature, they became co-authors of a textbook on the history of Ukrainian literature, they were like-minded on the issue of historical periodization of Ukrainian literature $^{14}$.

D. Chyzhevsky stated his theory in the research «Culture-historical epochs» $(1948)^{15}$ [53]. In this research the scientist contradicted the

\footnotetext{
${ }^{13}$ Горський В. С. Історія української філософії... Ст. 272-277.

14 Петров В., Чижевський Д., Глобенко М. Українська література. Iсторія української культури. Мюнхен; Львів: Укр. вільний ун-т, 1994. 380 ст.

15 Чижевський Д. Культурно-історичні епохи. 2-ге вид.. Авгсбург-Монреаль: Накладом Тов-ва прихильників УВАН, 1978. 16 ст. (Slavistica; № 78).
} 
«theory of progress», which described the historical development «as a way of gradual improvement, accumulation of cultural acquisitions» ${ }^{16}$. He divided the cultural history of Europe into «epochs» - Romance, Gothic, Renaissance, Baroque, «Enlightenment» (Classicism), Romanticism, Realism («New Enlightenment»), neoromantism. Every epoch, in the opinion of the researcher, is «the wholeness, a system of movements and changes, all of which have a certain direction», every epoch has its own character, «style». D. Chyzhevsky emphasized that the basic unit of historical study is the epoch, and the primary task of the historian is studying of the «style of the epoch». Moreover, the historian, «... achieving this goal or approaching to it, does not invent, does not form a certain picture, but discovers the wholeness of epoch's image, which is really the foundation of this epoch, which belongs to objective historical reality» ${ }^{17}$.

D. Chyzhevsky put an increased focus on «regularity» of periods' change, which are embodied in the change of styles. He called his concept the "theory of cultural waves" and associated its forthcoming with the works of V. Velflin ${ }^{18}$. The main idea of the «theory waves» of D. Chyzhevsky lies in the fact that every succeeding epoch denies, repudiates the main ideas, features of the previous one, at the same time forming its own style, it revives to some extent the ideals of the epoch, which preceded its antecessor. Thus, according to the scientist, «in any case earlier Middle Ages are more consistent with aesthetic ideals of the Renaissance than the later Middle Ages, which resemble Baroque by composing and dynamics of its works» and so on. Consequently, D. Chyzhevsky graphically depicts the scheme of historical development of European culture by a wavy line ${ }^{19}$.

D. Chyzhevsky considered the correlation between the concept of «epoch» and historical time the most vulnerable part of his conception; moreover he left the question of historicity/ahistoricity of epochs open.

It should be noted that D. Chyzhevsky presented the «theory of cultural waves» as a hypothesis, which, according to the author, required verification by the actual material. The concept of D. Chyzhevsky arose in the context of debate about the fate of Ukrainian culture in literary circles of emigration in Germany (V. Derzhavyn and others).

\footnotetext{
16 Там само. Ст. 5-6.

17 Там само. С. 7.

${ }^{18}$ Вёльфлин Г. Ренессанс и барокко.

${ }^{19}$ Чижевський Д. Культурно-історичні епохи. С. 12-13.
} 
D. Chyzhevsky believed that the use of cultural-historical method and pan-European scheme of development of culture of the Ukrainian material allows one to look at the history of Ukrainian culture as a part of "Pan-European integrity"20.

The views of V. Petrovon the historical process were described in various publications of Ukrainian emigration in Germany: historiosophical sketches "Historiosophical Essays", "Our Time, as it is», "Fundamentals of History", "Problems of the Epoch», "Modern Image of the World: the Crisis of Classical Physics",, "Principles of Poetics», "Christianity and Modernity", "Spiritual Currents of Europe of the New Age», "Modern Spiritual Currents in Europe», "The Masses, Machinery and Liberalism», etc., and theoretical excursions to historical and journalistic writings ("The Origin of the Ukrainian People», "Ukrainian Activists - Victims of Bolshevik Terror» and others), literary works («Francois Villon», "Lone Traveler Walks along a Lonely Road», "Tamed Gaydamak», "Professor Expresses his Views», "Pre-Easter», "Without the Ground», etc.) ${ }^{21}$.

The main core of the concept of V. Petrov was "the discreteness of time», "the isolation of individual of epochs»" and the relationship between them on the basis of denial and rejection of the idea of development. V. Petrov denied the principle of continuity of history: "The historical process is not a continuous flow of being. This flow is divided into specific gradations of time ${ }^{22}$. Thus, the epoch is a self-contained and enclosed in itself by the frames of dominant ideology "period of time". Therefore, the

\footnotetext{
${ }^{20}$ Ibid. C. 9.

21 Бер В. Наш час, як він є (3 приводу статті Нормана Казнса «Несучасність сучасної людини» «The Saturday Review of Literature. New York. 1946). Рідне слово: вісн. літератури, мистецтвва $i$ науки. Мюнхен; Бер В. Засади поетики. Від «Ars poetica» С. Маланюка до «Ars роеtica» доби розкладеного атома. МУР: зб. літературно-мистеиької проблематики. Мюнхен; Карлсфельд, 1946. 3б. 1. Ст. 7-23; Бер В. Сучасні духові течії в Свропі (1. Новіші вчення про всесвіт). Час. Фюрт, 1946. Чис. 42. Ст. 2-3; Бер В. Сучасні духові течії в Європі (2. Новіші вчення про походження людини). Час. Фюрт, 1946. Чис. 43. Ст. 2-3; Бер В. Сучасний образ світу: Криза класичної фізики. Арка. Мюнхен, 1947. Чис. 1. Ст. 2-6; Веріго Борис. [Віктор Петров] Маси, техніка й лібералізм (з приводу книги Хозе Ортеги і Гассет «Повстання мас»). Орлик: місячник культури $і$ суспільного життя. Берхтесхгаден, 1948. Чис. 3 (Березень). Ст. 33-35; Домонтович В. Самотній мандрівник простує по самотній дорозі. Вінсент Ван Гог (1833-1890): Біографічна новеля. Арка. Мюнхен, 1948. Чис. 5 (11). Ст. 25-34; Домонтович В. Самотній мандрівник простує по самотній дорозі. Вінсент Ван Гог (1833-1890): Біографічна новеля. Арка. Мюнхен, 1948. Чис. 5 (11). Ст. 25-34; Домонтович В. Приборканий гайдамака. Оповідання про Саву Чалого (розділи 1-2). Похід. Гайденав, 1947. Чис. 1. С. 7-11; Петров В. Історіософічні етюди. МУР : зб. літературно-мистецької проблематики. Мюнхен; Карлсфельд, 1946. Зб. 2. Ст. 7-19; Петров В. Християнство і сучасність. Орлик: місячник культури і суспільного життя. Берхтесхгаден, 1947. Чис. 2 (Лютий). Ст. 15-18; Петров В. Діячі української культури (1920-1940рр.) - жертви більшовицького терору. Украйнська літературна газета. Мюнхен. 1955. Чис. 1 (Липень); Петров В. Походження українського народу. К.: МП «Фенікс», 1992. 192 ст.

${ }^{22}$ Петров В. Історіософічні етюди. Ст. 7.
} 
historical process, the history of mankind, according to V. Petrov, is a successive change of epochs within the limits of which there are unique, peculiar only to them processes.

From the context of the works of V. Petrov it becomes clear that the epoch is a certain component of the historical process, which is recognized as the structural integrity, which is characterized by: the presence of the dominant ideology, sustainable correlation of the certain interdependent forms of economy, social institutions and cultural phenomena. V. Petrov understood the history as a process of being and changing of different selfsufficient epochs, each of which is characterized by its own affinity, different from affinity of other epoch. History is discrete, discontinuous; it includes inter epoch "fractures". The transition from one epoch to another through the fractures means that next to the processes of destruction, displacement, resettlement and migration, there also occurred a process of diffusion, deformation, inheritance, and learning. Furthermore, important factors of transformations are also external influences such as expansion, wars, disasters, destructions, cultural and economic relations and influences, natural factor and so on. Accordingly, the main subject of historical study of V. Petrov is the epoch, and the objective of the research is determination of methodology of epoch change.

The researcher tried to give an explanation of how one epoch became a different one. He believed that the change of epochs was due to the function of «overcoming», "contrasting", re-embodiment of the epoch into its contrast, not in terms of time. He was even speaking about "laws of epoch change ${ }^{23}$. However, according to V. Petrov, there are other forms of relations, presumably inherent to non-European civilizations. Whence, he mentions the connection of "Chinese type", which is an unchanging, sustainable existence. Unfortunately, the scientist did not develop this idea. But, everything seems to suggest that V. Petrov had an idea and his own vision of non-European, Oriental cultures, which is evidenced by some "remarks" in his works.

To some extent "the epoch" of V. Petrov corresponds to the "culturalhistorical type" in the theory of local civilizations, which is supra-ethnic socio-cultural communities, idiosyncratic "blocks" of world history, whose interaction determines the course of historical process.

${ }^{23}$ Ibid. Cт. 20, 26. 
Thus wise, the ideas of denial of world progress, discreteness of history (rejection of traditional notions of historical time), isolation and self-sufficiency of an epoch / culture syncretize researches of V. Petrov and O. Spengler. The epoch of V. Petrov as well as the "cultural-historical type" of O. Spengler, is bound to disappearance, which is peculiar to its nature. However, unlike O. Spengler, Ukrainian thinker saw a certain connection between the epochs/cultures, which reconciled his vision of history with the one of A. J. Toynbee. Thus, Toynbee captures «parentchild» relationship between particular civilizations. In other words, civilizations, changing each other, may form a sequence. For example, the Minoan civilization is followed by the Hellenic civilization and it is followed by Medieval Western civilization and so on. For Toynbee it is essential that some societies, joining the others, thereby provide a continuity of the historical process. We see similar thoughts about contacts of cultures in the works of V. Petrov. According to V. Petrov, there is a relationship between the epochs (Antiquity - Middle Ages - Modern Age - Present). For Toynbee, the link between different civilizations was a man - a permanent and regular element in history. In V. Petrov's theory, it is observed that the man is the mediator and the custodian of epoch's acquisitions.

The ideas of destruction of civilizations/the end of epochs which occur as a result of internal crisis and external factors (military defeats, destroyed, natural disasters, etc.) are somewhat similar in viewpoints of V. Petrov and A. J. Toynbee. Looking for the causes of decline and end of civilizations, A. J. Toynbee concluded that the growth of civilization is accompanied by its self-determination, and the main criterion and fundamental cause of the fracture is an internal explosion, through which the society loses the feature the self-determination. A. J. Toynbee tried to see certain patterns in the history of local civilizations, while the only law for V. Petrov was the change one era into another, the individuum and the unique were in the center of his attention. It is unlikely that V. Petrov was familiar with the works of A. J. Toynbee, but both thinkers were in the common scientific paradigm and could reach similar views on the historical process.

According to V. Petrov, the content of individual epochs is primarily determined by the dominant ideology. Accordingly, the change epochs is accompanied by the crisis of ideology. Middle Ages, Modern age and 
Modernity ("Our Time") are three eras of European history, which were in the thinker's center of attention. He considered theologism to be the ideological content of the Middle Ages, humanism - of the Renaissance, and rationalism, subjectivism, relativism, pluralism, and skepticism - of the Modern age ${ }^{24}$.

He has represented Ukrainian culture as a rightful and self-contained part of European civilization, which is «enduring» all those epochs that Europe has gone through.

Comprehension of different historical epochs, according to V. Petrov, occurs through the ideology, inner world, life and activities of specific individuals, typical representatives of their time. According to V. Petrov, each era has a certain type of personality (ideal figure of his time). Specific characters of literature and fictionalized images of his scientific, works that combine norms of life, morality, stereotypes of two epochs or reject the certain ones in favor of others, correspond to the catastrophic fractures of time ${ }^{25}$.

"Epoch theory" represents one of the possible variants of civilizational analysis of world history, but, unlike the majority of other civilizational theories it goes beyond purely historical and philosophical exposition and offers methodology of concrete historical material analysis. V. Petrov put the idea of epoch change on historical specificity of ancient history of Ukraine, the essence of historiosophical concepts of "the epoch", "the fracture", "the epoch change", "objection" was demonstrated in the published university lecture of V. Petrov "Origin of Ukrainian people" (Regensburg 1947).

Considerations of V. Petrov regarding the differences of the epochs, the principle of their objection, fracture, change and self-organization of the society also correspond to the latest methodological approaches in understanding of the historical process. A look at the history in terms of the idea of self-organization brings the concept of V. Petrov closer to synergistic approach, which considers the society be a complex system, all elements of which are interrelated. Changing of one of the backbone elements or implementation of newor even alien elements into the system

${ }^{24}$ Петров В. Історіософічні етюди. МУР: зб. літературно-мистецької проблематики. Мюнхен; Карлсфельд, 1946. Зб. 2. Ст. 7-19; Петров В. Історіософічні етюди. МУР: зб. літературно-мистецької проблематики. Мюнхен; Карлсфельд, 1947. 3б. 3. Ст. 7-10.

25 Мішеніна Н. Історіософський мотив зміни епох як модель внутрішнього інтертексту (проза Віктора Петрова-Домонтовича). Слово і час. 2002. № 11. Ст. 32. 
may lead to a qualitative degeneration of the entire system, especially if it is in unbalanced, unstable condition ${ }^{26}$.

\section{3. «Epoch Theory» in the Realities of the Soviet Science}

The fourth stage-extension and specification of the concept of ancient history of Ukraine (ethnogenesis of the Slavs) after returning to the Soviet Union, when the scientist was forced to adapt his «epoch theory» to the realities of the Soviet science.

In the 1960s the scientist continued his theoretical and practical researches in the field archeology, history, linguistics, ethnography, that allowed him to detail his conception of ancient history of Ukraine, to expand the source base and to include the latest scientific discoveries into it. At the same time V. Petrov implemented the theoretical and methodological principles of his conception in a veiled form on specific problems and periods in the works: «Ancient Slavs and their origin: the issue Slavic ethnogenesis» (1963), «Historical topography of Kyiv. The archeof the city. The city of Vladimir, structure and origin» (1964), "The Slavs and Byzantium. On the change of archaeological cultures on the territory of Ukraine in V-VII centuries A.D." (1965), "The Scythians. Language and ethnicity" (1968) and others ${ }^{27}$. He adapted his conception to the realities of the Soviet science, paid more attention to the socioeconomic component "the epoch".

V. Petrov's erstwhile achievements illustrate the breadth of the subject field and methodological approaches of national historical science which was made possible under the conditions of the Khrushchev Thaw. Decrease of ideological pressure on science was the result of the Thaw and "quiet" revision of the theory of historical materialism, a development of the ideas of "late" K. Marx on differentiation of mainstream of historical development in ancient times. For example, the so-called "second" discussion about the "Asiatic mode of production" unfolded in the Soviet and world science (the "first" took place in the Soviet Union in the second half of the 1920s - early 1930s.); this discussion eventually led to many discussions of urgent problems of the theory of historical process.

\footnotetext{
${ }^{26}$ Пригожин И., Стенгерс И. Порядок из хаоса. Новый диалог человека с природой. М.: Вектра, 2001. 420 ст.

27 Петров В. Давні слов'яни та їх походження: До проблеми слов'янського етногенезу. Украйнський історичний журнал. 1963. № 4. С. 36-44; Петров В. Слов’яни і Візантія. Про зміну археологічних культур на території України в V-VII ст. н. е. Археологія. 1965. Т. 18. Ст. 3-13; Петров В. Скіфи. Мова і етнос. К.: Наук. думка, 1968. 149 ст.
} 
Scientists expressed interesting ideas, including those concerning nonlinearity and polyvariety of the historical process ${ }^{28}$.

Today it becomes clear that the Soviet historiography was not a methodological monolith. But certain interpretations of Marxism, national romanticism, structuralism, the school «Annals» concealed under the veil with quotations of "classics", and even something so original and individual, that it is hard to define ${ }^{29}$.

V. Petrov's concept was presented in a relatively complete form in his work "Ethnogenesis of the Slavs" (Kyiv, 1972). Qualitative stages of Slavic ethnogenesis were matched with the scheme of division into the "epochs" of ancient history of Ukraine (from Tripillya to historical times of Slavdom). According to references in the work to the editions of 1966-1967 it is possible to determine the final phase of author's work at the text of the research «Ethnogenesis of the Slavs». From its abstract of 1966 it is clear that the structure of the proposed monograph «The Problem of Slavic Ethnogenesis. Ancient Slavs and their Origin» involved chapters on Byzantium and the Slavs, cultural and ethnic unity of Slavs in the V - VII centuries; which were not included in the publication. V. Petrov also planned monographic works on the ancient history of Kyiv and Slavic writing system at least up to XI century ${ }^{30}$.

$\mathrm{V}$. Petrov died finishing the main text of the work «Ethnogenesis of the Slavs». This research was published in 1972, thus it did not take into account relevant achievements of various branches of archeology and other sciences, materials of global new-building expeditions. This monograph was published (although it was incomplete and unedited by the author) during the ideological reaction that increased in the early 1970 s. Changes in the senior headquarters of the republic blocked the development of ethnogenetical studies, which did not meet a concept of the common Old Russian nation. M. Braichevsky, O. Kompan and O. Apanovych were fired

28 Семенов Ю. И. Теория общественно-экономических формаций и всемирный исторический процесс. Народы Азии и Африки. 1970. № 5. Ст. 82-95; Семенов Ю. И. Марксистско-ленинская теория общественно-экономических формаций и всемирная история. Актуальные проблемы марксистсколенинского учения об общественно-экономических формациях. М., 1975. Ст. 53-87; Семенов Ю. И. Разработка проблем истории первобытного общества в Институте этнографии АН СССР в «эпоху» Бромлея (воспоминания и размышления). Этнографическое обозрение. 2001.№ 6. Ст. 3-20; Хазанов А. М. О связи линейности и локальности с образом жизни. Советская этнография. 1974 . № 6. Ст. 58-61.

${ }^{29}$ Бойцов М. А. Вперед, к Геродоту! Казус: индивидуальное и уникальное в истории. М.: Российск. гос. гуманит. ун-т, 1999. Вып. 2. С. 31.

${ }^{30}$ Петров В. П. Язык. Этнос. Фольклор : автореф. по совокупности работ на соискание ученой степени кандидата филол. наук. К., 1966. Ст. 60. 
from the Institute of History of the Academy of Science of the USSR. The research of K. Guslysty "Historical Development of Ukrainian Nation" and multi-authored monograph «Ukrainians» were forbidden for publishing in 1972. But the censorship did not notice the sedition, especially since author's presentation ended in V-VI centuries, videlicet in "pre-Kyiv" period.

The monograph «Ethnogenesis of the Slavs» was the result of scientist's years-long researches, but at the same time it was expanded and revised version of his research "Origin of the Ukrainian people" (1947). The concept of epoch in "Ethnogenesis of the Slavs" was not presented as vividly as it was in 1947. It can be observed even from the contents of the book $^{31}$. However, based on the structure of the text and logic of presentation, it is clear that the author followed his concept. Clearly highlighted by V. Petrov in "The Origin of the Ukrainian people» epochs do not correspond to formational periodization of history: Trypolian, Aftertrypolian (Pre-scythian), Scythian, ancient (the first period), ancient (the second period). This scheme generally corresponds to structural sections of the research «Ethnogenesis of the Slavs»: «Trypolian culture» corresponds to Trypolian epoch, "the era of Urban-Usatove culture" and "the Middle Dnieper culture" correspond to After-trypolian epoch; "Scythians" corresponds to Scythian epoch; "Zarubintsy era» and "Chernyakhov culture» correspond to periods of ancient epoch.

V. Petrov's conception of ancient history of Ukraine captures the period starting from Eneolithic Period up to the times of Historic Slavdom (IV century B. C. - VI century C. E.). According to V. Pertrov, the history of Ukraine is discrete, discontinuous, «fractures» between the epochs are peculiar to it (between Trypolian and After-trypolian, Zarubintsy and Chernyakhov (Ancient), and Slavic). The transition from one epoch to another through the fractures means that «next to the processes of destruction, displacement, resettlement and migration, there also occurred a process of diffusion, deformation, inheritance, and learning. There appeared not only exclusion, but inclusion as well. There was a fracture as well as percussion» ${ }^{32}$. The scientist illustrates his statement about the ambiguity of time through the analysis of archaeological sources according to which After-trypolian epoch was more primitive than the previous one -

\footnotetext{
${ }^{31}$ Петров В. Етногенез слов'ян. Джерела, стан розвитку і проблематика. К., 1972. Ст. 214.

${ }^{32}$ Ibid. CT. 38.
} 
Trypolian, and Chernyakhov epoch was higher than the historical Slavdom culture before the creation of Kievan Rus ${ }^{33}$.

V. Petrov studies the overall pattern of change of epochs on the territory of Ukraine in the general European context. In ancient European history as well as in the history of Middle Ages and Modern Times, the historian distinguishes the main "gradations of time": the old non-IndoEuropean world and the new one - the era of Indo-European peoples domination that continues to the present. There was a fracture between these epochs, a catastrophe which falls at II millennium B.C. It's not just about the linguistic aspect, but also about the structure of historical existence. For V. Petrov, a man, a leading figure, is an indication of the epoch: "A farmer is replaced by a rider. A peaceful settler is replaced by a warrior". He believed, that during After-trypolian (Pre-scythian) and Scythian epoch «a rider becomes a leading figure of the time, at this very time he extrudes a farmer and pushes him on the back burner». Moreover, he highlighted that he means "economy as well as the social structure of the country", that it «equally concerns economic, social, political and public life ${ }^{34}$. According to V. Petrov, ancient history of Ukraine is a successive change offarmer and rider epochs ${ }^{35}$.

For V. Petrov, «Epoch theory» became a methodological basis for solving the problems of ethnogenesis, understanding the concept of «ethnos» and correlation between the epochs change with the stages of ethnogenesis. The scientist outlined his concept of the origin of Slavs and the origins of the Ukrainian people in the monographs "The Origin of the Ukrainian people" ${ }^{\text {"36 }}$ and «Ethnogenesis of the Slavs. Sources, stages of development and problematic» $(1972)^{37}$, and in the articles "Anthropological features of the Ukrainian people",38 and others.

V. Petrov considered the concept of ethnos to be historical, and therefore the process of ethnogenesis is historical as well and takes place within the limits of anall-sufficient epoch, and therefore is discrete. Ethnos of one epoch is not the ethnos of some other epoch; every epoch has "its

${ }^{33}$ Ibid. CT. 28.

${ }^{34}$ Ibid. CT. 36-40.

${ }^{35}$ Ibid. Ст. 46.

${ }^{36}$ Петров В. Походження українського народу. К.: МП «Фенікс», 1992. 192 ст.

${ }^{37}$ Петров В. Етногенез слов'ян...

38 Петров В. Антропологічні особливості українського народу (Початок). Орлик: місячник культури $і$ суспільного життя. Берхтесхгаден, 1947. Чис. 5 (Травень). Ст. 15-18; Петров В. Антропологічні особливості українського народу (Закінчення). Орлик: місячник культури $і$ суспільного життя. Берхтесхгаден, 1947. Чис. 6 (Червень). Ст. 16-19. 
direction of ethnos-creating" according to its properties, so ethnos of different epochs are not identical. Within the limits of each epoch ethnogenesis of a separate nation has its own peculiarities and differences. Therefore, the researcher believes that characteristic feature of an ethnic history is continuity of its progressive development.

Later, in $1970 \mathrm{~s}$, the ethnogenetical provisions about the discreteness of processes were elaborated in the works of Soviet ethnographers. Ethnic processes associated with the "fracture" in the development, were called «ethno-discrete». Their special role is that they lead humanity to move into a new ethnic state. In contrast to the ethno-evolutionary processes that are associated only with changes in individual components of ethnic system, $\mathrm{J}$. Bromley noted that it is the discrete processes that caused the emergence of the first ethnic communities ${ }^{39}$.

Ethnogenesis of the Ukrainians, according V. Petrov, occurred within the limits of several epochs that changed one another. The relationship between these epochs was not a correlation of "Chinese type" and was carried out in the shifts, through changes, disasters and crises. "This relationship is subject to laws of epoch change. History of Ukraine passed through several epochs. That is why the concept of epoch as structural integrity is one of the key, guiding principles in our modern historiosophical concepts and studies", - wrote V. Petrov ${ }^{40}$.

Of course, the scientist was not released from compulsory quotations of classics of Marxism-Leninism and made the necessary references, but mainly to F. Engels and only when it was appropriate, and coincided with the logic of his scientific conclusions.

Developments of V.Petrov remained neglected by the experts, because there was no author's presentation of theoretical principles and terminological apparatus for methodologically unilaterally trained Soviet scientists. They were practically the accumulation of factual material (outdated to some extent).

On the other hand, Marxism - "camouflaged" concept of V. Petrov is mechanically perceived as Marxism even to this day, and sometimes it distorts the meaning of scientific achievements of the researcher. Thus, in the «Comments» to republication of the work "The Origin of the Ukrainian people" in 1992 the authors (N. Kravchenko and Y. Pavlenko) proposed

39 Абашина Н. С. Вивчення етногенезу слов’ян в працях В. П. Петрова. Археологія. 1986. Вип. 9. Ст. 10-11; Бромлей Ю. В. Этнос и этнография. М., 1973. Ст. 153-154.

${ }^{40}$ Петров В. Етногенез слов'ян. Ст. 21. 
not completely correct attempt of construction of the concept "epoch": "From the context of work it is implied that the epoch is not a formation in its Marxist sense, although according to a number of features these categories come near. In understanding of the researcher the "epoch" is a certain stage of human development, which is recognized as a structural integrity, which is characterized by a constant relationship (correlation) of certain, interrelated forms of economy, social institutions, cultural phenomena, etc ${ }^{41}$. I believe that terminological addressing to stability does not correlate with the principle of epoch changing and understanding of historical progress in the concept of V. Petrov.

Y. Pavlenko was one of the first national historians, who started to use the civilizational approach starting in the late 1980s, combining it with the theory of formations. In the views of V. Petrov he saw Marxist basis, and in the works published after returning of the scientist to Ukraine he saw the use of exclusively formational theory that prevailed in the Soviet social sciences $^{42}$. Here is how Y. Pavlenko briefly stated the essence of the approach, that was affirmed by V. Petrov, and that was acceptable for him as a moderate version of formational theory application in new methodological paradigms: a systematic understanding of the historical process involves selection of qualitative stages of Slavic ethnogenesis relevant to special forms of social and economic organization (pre-class, early class and so on) and reflected in the specifics of archaeological materials ${ }^{43}$.

However, the fundamental work of Y. Pavlenko «Prehistory of old Russians in the global context» $(1994)^{44}$ demonstrates not only the influence of Y. Braychevsky, whom the author expresses thanks in the preface, but also the influences of $\mathrm{V}$. Petrov. The fact of the matter is not only in numerous references to specific historical conclusions and results of field studies of V. Petrov, but also in general perception of his understanding of schematic-dynamic changes of ancient stages of Slavogenesis. The research of Y. Pavlenko is performed on the modern scientific level, on the relevant terminological and theoretical basis, on the grounds

\footnotetext{
41 Кравченко Н., Павленко Ю. Коментар до праці «Походження українського народу». Походження украӥнського народу. К.: МП «Фенікс», 1992. Ст. 115.

${ }^{42}$ Там само.

43 Павленко Ю. В. Раннеклассовые общества (генезис и пути развития). К.: Наук. думка, 1989. Ст. 206-207.

${ }^{44}$ Павленко Ю. В. Передісторія давніх русів у світовому контексті. К.: Фенікс, 1994. 400 ст.
} 
of new source complexes. It covered the "prehistory of Russes» (the period from the third millennium B. C. tolate first millennium C. E.).

\section{CONCLUSIONS}

Incompatibility of theoretical views of V. Petrov with stadially linear, deterministic, incrementally progressive vision of the historical process, which was dominant in Soviet science, is evident. Epoch theory of V. Petrov is an individual phenomenon of national historiography, but not an example of "soft revision of Marxism". However, this does not exclude recognition of socio-economic component in the concept of «epoch» as structural integrity by the academic.

The main tool for cognition of the past for the philosopher is his "epoch theory", which is quite flexible and provides identification of unique internal laws for each of the epochs, it does not recognize the constant laws in their changing, and therefore allows enough flexibility to generalize specific historical material. V. Petrov's conception of the ancient history of Ukraine is a holistic, thorough and functional explanatory model. V. Petrov's scientific heritage of 1940-1950's, the essence of his ideas can be understood only through his "epoch theory", because the internal logic of presentation, scientific argumentation and conclusions of the researcher are based on such concepts as "era", "epoch", "fracture", "discreteness" and others.

Conception of V. Petrov was not accepted by his contemporaries and to this day it remains obscure to most researchers. Why? The most common causes are ambiguity of terminology and the lack of a holistic presentation of the conception. Its basic theoretical principles were formulated during DP and published in Ukrainian short-run camp publications in post-war Germany, and fundamental works based on specific historical material were published after two decades in Soviet Ukraine without a systematic presentation of their theoretical principles.

Moreover, V. Petrov's views could not be perceived in the USSR due to their nonconformity with formational scheme of historical process. In the West-due to language barriers and poor awareness with his work, in the environment Ukrainian emigration -due to odiousness of the author (Soviet spy) and nonconformity of their conceptual and methodological principles with the scheme of continuous national history by M. Hrushevsky. 
The lack of attention in modern science can be explained by a complex of reasons. First of all, it is the lack of a general analysis of scientific achievements of Viktor Petrov, debates around personality of the scientist and the writer, sometimes exclusively in the plane of the ideological, political and moral evaluations. Secondly, it is the sustainability of historiographic «templates» and «cliché» (through the formal indicator V. Petrov is automatically reckoned among a cohort of Marxist Historians). Thirdly, what can be considered as an advantage of "epoch theory" in comparison with other historiosophical concepts, namely application to of specific historical material, became its weakness. From the perspective of the modern science the range of archaeological sources of V. Petrov seems too narrow, the findings on specific problems of ancient history of Ukraine are outdated, there is an underestimation of migration processes in ethnogenetical processes, the actual exception from the general scheme of the Bronze Age seems unclear and, therefore, interest in the concept itself is lost. By contrast a historiosofic concept, such as A. J. Toynbee's, this is not burdened with suchparticularities and it is "not threatened" by new scientific discoveries and it remains popular for decades.

However, complex reconstruction of conceptual positions, terminology, instrumentarium and methodological foundations of "epoch theory", practical realization of creative potential of world and national history study in the works of V. Petrov may be important for the creation of modern theoretical models of national history.

Also, no less important today for the Ukrainian historical science is the answer to the question of the meaning of V. Petrov's concept in the light of M. Hrushevsky's canonical scheme of the history of Ukraine. The principle of continuity of national history, justified by M. Hrushevsky, has always had an ideological significance; modern society and scientific environment are not ready to opt for a new-fangled versions of discontinuous national history. At the same time, there are more and more calls to pay particular attention to the moments of breaks, which contain much more powerful heuristic potential and are important for understanding of the hypothetical "historical inheritance" and social genealogy than insistence on ideologically motivated continuity ${ }^{45}$. Among

\footnotetext{
${ }^{45}$ Касьянов Г. В., Толочко О.П. Національні історії та сучасна історіографія : виклики й небезпеки при написанні нової історії України. Украӥнський історичний журнал. 2012. № 6. Ст. 21.
} 
other things the structural-synergistic model of Ukrainian history is $\operatorname{proposed}^{46}$.

It should be noted, that since the principles of "epoch theory" were applied by V. Petrov for organizing specific historical material of ancient history of Ukraine, this meant differentiation from the "History of UkraineRus" by M. Hrushevsky in chronological terms: when M. Hrushevsky started Ukrainian history with the Antes, V. Petrov's presentation of early stages of Ukrainian ethnogenesis ended with the Antes. The picture of Slavo-genesis at the turn of Millennium - the first half of the first millennium C.E., as it is depicted in the works of V.Petrov and M. Braychevsky, provides compelling evidence in support of early versions Ukraino-genesis, the supporter of which was M. Hrushevsky ${ }^{47}$.

Therefore, V. Petrov's concept of the ancient history of Ukraine was based on his "epoch theory", which rejected the idea of continuous progress and emphasized the discreteness of historical process. Independently developed, based on personal experience, observations and emotions, it discovers the greatest resemblance to the theory of local civilizations of O. Spengler and A.J. Toynbee. The expression of national identity as a philosopher and a scientist, an appeal to the spiritual culture of the Ukrainian people is observed in the views of V. Petrov, as well as in the views of other prominent thinkers - his contemporaries (M. Khvylovy, D. Chyzhevsky and others). At the same time it can be argued that approaches of $\mathrm{V}$. Petrov exhibit a certain correspondence to synergistic paradigm of understanding of the historical process, they were in unison with the latest scientific theories and far ahead of their time.

However, the historical scheme of V. Petrov is detached from the history of Ukrainian historical thought, as it has not been assessed in historiography; it remained out of sight of scientists and has no direct followers.

\section{SUMMARY}

Viktor Petrov (1894-1969) was one of the brightest Ukrainian intellectuals of his time - an outstanding scientist of encyclopedic erudition (historian, ethnographer, archaeologist, literary scholar, linguist, folklorist

\footnotetext{
${ }^{46}$ Колесник I. Український гранд-наратив. Ретроспективи та перспективи. Ейдос: альманах теорї та історії історичної науки. К.: Ін-т історії НАН України, 2008. Вип. 3. Ст. 175-177.

Залізняк Л. Українці: витоки та історичні долі. К.: Темпора, 2011. Ст. 218; Павленко Ю. В. Раннеклассовые общества... Ст. 115.
} 
and philosopher), science manager, public figure and writer of the circle of neoclassicists and Soviet intelligence agent. V. Petrov's top achievement as an intellectual and versatile scholar is his "epoch theory". The thinker suggested an original conception of ancient history of Ukraine, which became an important theoretical and practical contribution to Ukrainian historiography. His concept was based on the discrete, cyclical vision of the historical process and was in the line with the main trends of European historiosophical thought of 1920-1940, it was directly in the context of intellectual ideasof N. Berdyaev, V. Velflin, N. Danilevsky, A.J. Toynbee, S. Freud, M. Foucault, M. Khvylovy, D. Chyzhevsky, F. Schmitt, O. Spengler and the existentialists. On the basis of the «epoch theory» the scientist developed a scheme of ancient history of Ukraine ("prehistory of Ukrainian people") and a scheme of ethnogenesis of Ukrainian people as a part of European history. This opened a new way for the development of national historical science and could cause a «revolution» in Ukrainian historical writing. However, intellectual initiative of the scientist was not accepted by his contemporaries and to this day it remains outside the main directions of theoretical and practical search of historians.

This article deals with the content and the genesis of Petrov's «epoch theory».

\section{REFERENCES}

1. Абашина Н. С. Вивчення етногенезу слов'ян в працях В.П. Петрова. Археологія. 1986. Вип. 9. Ст. 6-13.

2. Андрєєв В. М. Віктор Петров: Нариси інтелектуальної біографії вченого: монографія. Дніпропетровськ: Герда, 2012. 476 с.

3. Базаров В. О. Шпенглер и его критики. Красная Новь. 1922. № 2. Ст. 212-225.

4. Бер В. Сучасні духові течії в Свропі (1. Новіші вчення про всесвіт). Час. Фюрт, 1946. Чис. 42. Ст. 2-3.

5. Бер В. Засади поетики. Від «Arspoetica» Є. Маланюка до «Arspoetica» доби розкладеного атома. МУР: зб. літературномистецької проблематики. Мюнхен: Карлсфельд, 1946. Зб. 1. Ст. 7-23.

6. Бер В. Наш час, як він є (3 приводу статті Нормана Казнса «Несучасність сучасної людини» «Тhe Saturday Reviewof Literature. 
New York. 1946). Рідне слово: вісн. літератури, мистеџтва і науки. Мюнхен: Карлсфельд, 1946. Чис. 8. Ст. 28-40.

7. Бер В. Сучасні духові течії в Європі (2. Новіші вчення про походження людини). Час. Фюрт, 1946. Чис. 43. Ст. 28-40.

8. Бер В. Сучасний образ світу: Криза класичної фізики. Арка. Мюнхен, 1947. Чис. 1. Ст. 2-6.

9. Бойцов М.А. Вперед, к Геродоту! Казус: индивидуальное и уникальное в истории. М.: Российск. гос. гуманит. ун-т, 1999. Вып. 2. Ст. 17-41.

10. Бромлей Ю. В. Этнос и этнография. М., 1973. 284 ст.

11. Брюховецький В. Віктор Петров: верхи долі - верхи і долі. К.: Темпора, 2013. 168 ст.

12. Вёльфлин Г. Ренессанс и барокко; [пер. снем. Е. Г. Лундберга]. СПб.: Азбука-классика, 2004. 288 ст.

13. Веріго Борис [Віктор Петров] Маси, техніка й лібералізм (з приводу книги ХозеОртеги і Гассет «Повстання мас»). Орлик: місячник культури і суспільного життя. Берхтесхгаден, 1948. Чис. 3 (Березень). Ст. 33-35.

14. Горський В.С.Історія української філософії. 3-е вид.. К.: Наукова думка, 1997. 287 ст.

15. Домонтович В. Приборканий гайдамака. Оповідання про Саву Чалого (розділи 1-2). Похід. Гайденав, 1947. Чис. 1. Ст. 7-11.

16. Домонтович В. Самотній мандрівник простує по самотній дорозі. Вінсент Ван Гог (1833-1890): Біографічна новеля. Арка. Мюнхен, 1948. Чис. 5 (11). Ст. 25-34.

17. Домонтович В. Без грунту. Украӥнський засів. Х., 1942. Чис. 2. Ст. $30-57$.

18. Домонтович В. Без грунту. Продовження. Украйнський засів. Х., 1943. Чис. 4. Ст. 49-71.

19. Домонтович В. Болотяна Лукроза. Київські неокласики. К.: Факт, 2003. Ст. 271-301.

20. Залізняк Л. Українці: витоки та історичні долі. К.: Темпора, 2011.424 ст.

21. Зашкільняк Л. Методологія історії від давнини до сучасності. Львів: Львів. держ. ун-т ім. І. Франка, 1999. 224 ст.

22. Ионов И. Н. Рождение теории локальных цивилизаций и смена научных парадигм. Образы историографии. М., 2001. Ст. 59-84. 
23. Ионов И. Н. Теория цивилизаций. Этапы становления. Новая и новейшая история. 1994. № 4/5. Ст. 33-50.

24. Касьянов Г. В., Толочко О. П. Національні історії та сучасна історіографія : виклики й небезпеки при написанні нової історії України. Украӥнський історичний журнал. 2012. № 6. Ст. 4-24.

25. Колесник I. Український гранд-наратив. Ретроспективи та перспективи. Ейдос: альманах теорії та історії історичної науки. К.: Ін-т історії НАН України, 2008. Вип. 3. С. 153-177.

26. Космина В. Г. Проблеми методології цивілізаційного аналізу історичного процесу. Запоріжжя: Запоріз. нац. ун-т, 2011. 310 ст.

27. Кравченко Н., Павленко Ю. Коментар до праці «Походження українського народу». Походження українського народу. К.: МП «Фенікс», 1992. Ст. 114-164.

28. Михайловский И. Б. Архитектурные ордера. М, 1925. 125 ст.

29. Мішеніна Н. Історіософський мотив зміни епох як модель внутрішнього інтертексту (проза Віктора Петрова-Домонтовича). Слово і час. 2002. № 11. Ст. 26-32.

30. Павленко Ю. В. Передісторія давніх русів у світовому контексті. К.: Фенікс, 1994. 400 ст.

31. Павленко Ю. В. Раннеклассовые общества (генезис и пути развития). К.: Наук. думка, 1989. 288 ст.

32. Петров В. Антропологічні особливості українського народу (Початок). Орлик: місячник культури $і$ суспільного життя. Берхтесхгаден, 1947. Чис. 5 (Травень). Ст. 15-18.

33. Петров В. Антропологічні особливості українського народу (Закінчення). Орлик: місячник культури $і$ суспільного життя. Берхтесхгаден, 1947. Чис. 6 (Червень). Ст. 16-19.

34. Петров В. Готи на Україні та культура полів поховань. Украӥнський засів. Х., 1942. Чис. 1. Ст. 61-65.

35. Петров В. Давні слов'яни та їх походження: До проблеми слов'янського етногенезу. Украӥнський історичний журнал. 1963. № 4. Ст. 36-44.

36. Петров В. Діячі української культури (1920-1940рр.) жертви більшовицького терору. Українська літературна газета. Мюнхен, 1955. Чис. 1 (Липень).

37. Петров В. Етногенез слов'ян. Джерела, стан розвитку i проблематика. К., 1972. 214 ст. 
38. Петров В. Історіософічні етюди. МУР: зб. літературномистецької проблематики. Мюнхен; Карлсфельд, 1946. Зб. 2. Ст. 7-19.

39. Петров В. Походження українського народу. К.: МП «Фенікс», 1992. 19 ст.

40. Петров В. Скіфи. Мова і етнос. К.: Наук. думка, 1968. 149 с.

41. Петров В. Слов'яни і Візантія. Про зміну археологічних культур на території України в V-VII ст. н. е. Археологія. 1965. Т. 18. Ст. 3-13.

42. Петров В., Чижевський Д., Глобенко М. Українська література. Історія украӥнської культури. Мюнхен; Львів: Укр. вільний ун-т, 1994. 380 ст.

43. Петров В. Християнство і сучасність. Орлик: місячник культури і суспільного життя. Берхтесхгаден, 1947. Чис. 2 (Лютий). Ст. $15-18$.

44. Петров В. П. Язык. Этнос. Фольклор : автореф. по совокупности работ на соискание ученой степени кандидата филол. наук. К., 1966. 61 ст.

45. Пригожин И., Стенгерс И. Порядок из хаоса. Новый диалог человека с природой. М.: Вектра, 2001. 420 ст.

46. Пятаков Г. Философия современного империализма (Этюд о Шпенглере). Красная новь. 1922. № 3. Ст. 182-197.

47. Репина Л. П., Зверева В. В., Парамонова М. Ю. История исторического знания. М.: Дрофа, 2004. 288 ст.

48. Семенов Ю. И. Марксистско-ленинская теория общественноэкономических формаций и всемирная история. Актуальные проблемы марксистско-ленинского учения об общественноэкономических формациях. М., 1975. Ст. 53-87.

49. Семенов Ю. И. Разработка проблем истории первобытного общества в Институте этнографии АН СССР в «эпоху» Бромлея (воспоминания и размышления). Этнографическое обозрение. 2001. № 6. СТ. 3-20.

50. Семенов Ю. И. Теория общественно-экономических формаций и всемирный исторический процесс. Hapoдbl Азии и Африки. 1970. № 5. Ст. 82-95.

51. Хвильовий М. Україна чи Малоросія? Санаторійна зона: оповідання, новели, повісті, памфлет. Харків: Фоліо, 2008. Ст. 334-381. 
52. Хазанов А. М. О связи линейности и локальности с образом жизни. Советская этнография. 1974. № 6. Ст. 58-61.

53. Чижевський Д. Культурно-історичні епохи. 2-гевид. Авгсбург-Монреаль: Накладом Тов-ва прихильників УВАН, 1978. 16 ст. (Slavistica № 78).

54. Шмит Ф. И. Искусство - его психология, его стилистика, его эволюция. Харьков, 1919. 328 ст.

55. Шмит Ф. И. Законы истории. Введение к всеобщей истории искусств. Вып. 1. Харьков, 1916. 198 ст.

56. Яковенко Н. Вступ до історії. К.: Критика, 2007. 375 ст.

\section{Information about the author:} Andryeyev V. M., PhD hab. (History), Professor, Professor at the Department of Ukraine's History, Borys Grinchenko Kyiv University 18/2, Bulvarno-Kudriavska St., Kyiv, 04053, Ukraine 


\section{DEVELOPMENT OF HYGIENE OF FARM ANIMALS \\ IN UKRAINE (THE SECOND HALF OF THE 19th - EARLY 21th CENTURIES)}

\section{Bey R. V.}

\section{INTRODUCTION}

In recent conditions the solving the problem of food independence of Ukraine, the priority is given to the growth of the level of scientific support of the livestock industry. Among the complex of animal sciences, which are called to promote qualitative improvement of the tribal resources of the country, a special place is devoted to zoo-hygiene, the main task of which is to provide health care and high productivity of farm animals on the basis of development and introduction of rational methods of their feeding, breeding and keeping.

Zoo-hygiene as a component of animal science studies the interaction of the organism of farm animals and the environment for the development of scientifically based methods of hygiene of their keeping, care and feeding; reducing the negative impact of environmental factors on animals and maximizing the positive effects of external factors on health and improving their productivity. Thus, regulation of the influence of external conditions, managed by a person with the help of certain methods of animal keeping and care, makes it possible to achieve both the preservation and improvement of livestock, and further increase its productivity.

The achievements of scientists in the field of farm animal hygiene confirm the real scientific potential of the Ukrainian community. They are a powerful theoretical and methodological basis for developing a further strategy for animal husbandry development in Ukraine. Despite the importance of this direction, by this time, a comprehensive research of the history of its development has not yet been held. Previous researches (Alikaiev V.A. ${ }^{1}$, Demchuk M.V. ${ }^{2}$, Kalitaiev M.V. ${ }^{3}$, Krasyi V.V.,

\footnotetext{
${ }^{1}$ Аликаев В. А. Достижения советской зоогигиены и ее дальнейшие задачи. Гигиена сельскохозяйственных животных: тр. XXIX пленума ветеринарной секции Академии. М.: Сельхозгиз, 1950. C. 8-22.
} 
Chornyi M.V. ${ }^{5}$, Borodai I.S. ${ }^{6}$, etc.) have considered some aspects of the formation of hygiene of animal feeding, keeping, care.

During the period of development of statehood in Ukraine, fundamental research was not carried out which would comprehensively cover the formation and development of the scientific foundations of farm animal hygiene as a basis for the growth of profitability and competitiveness of the livestock industry. In view of this, this research has a theoretical and applied value.

The article is prepared in accordance with the tasks of the state budget topic 0116U002102 "Scientific-organizational and regulatory bases of innovative activity in the system of agrarian science: theoretical and methodological, historical and scientific studies, archival, bibliographic aspects of the research".

The purpose of the research is to analyze the history and the periods of formation of hygiene of farm animals in the context of the development of world branch scientific thought. The general scientific and interdisciplinary methods used to solve research tasks. Particular attention paid to special historical methods, source analysis. The source base of the research includes a complex of diverse documents, the basis of which are archival materials.

\section{Formation of Farm Animal Hygiene as a Researching Direction and Discipline}

The study and application of hygienic methods for farm animal keeping and care, as well as the development of measures for the protection of their health, have begun before the BC in India, Babylon, Ancient Egypt, Greece, Rome. Already at the beginning of the $17^{\text {th }}$ century for the protection of human and animal health in the Russian Empire, state regulations namely orders for the placement of cattle mammals in special

\footnotetext{
${ }^{2}$ Демчук М. В. Основні досягнення і перспективи розвитку гігієни тварин в Україні (в світлі розвитку наукових ідей професора А.К. Скороходька). Науковий вісник Начіонального аграрного університету. К, 1998. Вип. 12. С. 25-28.

${ }^{3}$ Калитаев М. В. О некоторых проблемах развития зоогигиены. Ветеринария. 1966. № 1. С. 90-92.

${ }^{4}$ Красій В. В. Роль і значення дисципліни «гігієна тварин» у підготовці сучасних фахівців тваринництва. Науковий вісник Національного аграрного університету. К, 1998. Вип. 12. С. $32-36$.

${ }^{5}$ Чорний М. В. Зоогігієна: історія, проблеми і завдання курсу при підготовці зооветспеціалістів. Науковий вісник Національного аграрного університету. К, 1998. Вип. 12. С. 26-32.

${ }^{6}$ Бородай І. С. Теоретико-методологічні основи становлення та розвитку вітчизняної зоотехнічної науки. Вінниця, 2012. 416 с.
} 
areas on base sanitary considerations, the deep burial of animal carcasses, the ways of their transportation, etc. were adopted.

At the beginning of the $18^{\text {th }}$ century, Peter I's reforms touched upon political, cultural and economic life, matters relating to the animal keeping and care. His name is associated with the development of dairy cattle farming in the north, horse breeding and fine-grained sheep. In the history of Russian legislation, the order of the Emperor of August 19, 1723, with the addition of «Кондиціï про утримання овець багатовотчинних людей» of July 30, 1722, was received special significance. These rules described certain methods of feeding, drinking, equipment for saving and development of fine-grained sheep in the farms .

The best practices of the animal keeping, care and feeding were developed by the St. Petersburg Academy of Sciences, organized in 1724. On the basis of the Academy's proposals, formulated as a result of the study of the methods of animal keeping and feeding in the Russian farms, the Senate Order «O содержании скота в удобных хлевах и на хорошем корме в предосторожность от болезней и падежа» was prepared on April 12, $1770^{8}$.

The first scientific works on farm animal hygiene have published in Russian at the end of the $18^{\text {th }}$ century. One of them is the monograph «Руководство к размножению и поправлению домашнего скота» (1794) by Professor M.G. Livanov that summarizes the main zoo-hygiene rules. In the middle of the 19th century the books and manuals on farm animal hygiene have been published by a number of authors, in particular S. M. Khodetskyi's «Руководство к размножению и поправлению домашнего скота» (1851) and others. After the land reform of 1861, a state order for the production of agricultural products was formed, attention was paid to the spread of agricultural knowledge, the purchase of equipment, seeds and cattle from the West. During this period, the translated manuals on zoology by Wilkens (1880), Damman (1884), Gaubner (1878), Roeff (1878), and others were especially distributed in Russian Empire.

It should be noted that in the early $20^{\text {th }}$ century the teaching of the farm animal hygiene course was mainly carried out according to textbooks

\footnotetext{
${ }^{7}$ Аликаев В. А. Достижения советской зоогигиены и ее дальнейшие задачи. Гигиена сельскохозяйственных животных: тр. XXIX пленума ветеринарной секции Академии. Москва : Сельхозгиз, 1950. С. 8-22.

${ }^{8}$ Аликаев В. А. Зоогигиена. Москва : «Колос», 1976. 256 с.
} 
prepared by German scientists. In particular, a textbook writing by Professor of Elden Agricultural Academy, Director of the Hanover Veterinary School K. Damman became very popular. Its part was translated in Russian by Y. Shmulevych and published under the title «Гигиена сельскохозяйственных домашних животных» (1884). The textbook contained 11 lectures that covered the concept of farm animal hygiene, which at that time was called "veterinary police". The German scientist M. Climmer in famous monograph «Ветеринарна гігієна» (1908) for the first time identified the hygiene of farm animals as an independent science, systematized and synthesized its foundations ${ }^{9}$.

By that time, the first domestic zootechnical guides by I. Popov, G. Svetlov, M. Chyrvinskyi, M. Ivanov, who consider this branch of knowledge as a component of zootechnics, had already published. Thus, texbook "Общедоступный лечебник домашних животных" (1904) by Ya. Shmulevych contains a chapter entitled "Zoo Hygiene", where the author states that farm animal hygiene is intended to study all conditions conducive to the saving of the health of domestic animals. In this sense, it includes not only immediate care, but also the conditions for rational feeding and the study of all measures to prevent the action of pathogens. The chapter consists of the following subchapters: 1) dieta; 2) caring for livestock; 3) poultry care ${ }^{10}$.

After the organization of higher veterinary schools in Russia, some information on farm animal hygiene taught in the course "General Livestock". This information was most fully included in the textbook «Курс общего скотоводства» by Professor I. Popov - one of the founders of farm animal hygiene, published in 1894. According to his definition, the main task of farm animal hygiene is the study of various external conditions and its impact on the organism of the animals. Since external conditions can be unfavorable, farm animal hygiene develops the most appropriate measures to weaken its actions. The book «Зоогигиена. Краткий очерк разумного использования домашних животных» by G.I. Svetlov, published in 1911, played a major role in promoting farm animal hygiene information. The book «Загальне тваринництво» by

\footnotetext{
${ }^{9}$ Бородай I. С. Теоретико-методологічні основи становлення та розвитку вітчизняної зоотехнічної науки. Вінниця, 2012. 416 с. C. 7-10.

10 Коропов В. М. Из истории ветеринарного образования в России. Ветеринария. 1947. № 9.
} 
M.P. Chyrvinskyi, published in 1912, consists detailed information, provided to students on farm animal hygiene ${ }^{11}$.

In pre-revolutionary period, agriculture and animal husbandry did not create favorable conditions for introducing new rational methods of animal care, keeping and feeding. The scientific development of issues of farm animal hygiene was carried out not enough, mainly, it concerned the conditions and characteristics of landowner farms. The study of the conditions for animal keeping, care of them in the peasant farms and the scientific development of farm animal hygiene issues regarding their inquiries were casual and carried out concurrently. Research work on farm animal hygiene was carried out, as a rule, at the personal initiative of veterinarians and agronomists, employees of departments of higher educational establishments and agricultural research institutions. The attempts of some zemstvo veterinarians and agronomists to introduce into the peasant farms the rules and norms of hygiene of farm animal keeping and rational care for them did not contribute to a noticeable improvement in the sanitary state of livestock ${ }^{12}$.

The state of hygiene of farm animals as a research direct and as a discipline in higher education improved somewhat after the revolution in 1917. In 1921-1929, Soviet farm animal hygiene and popularization of industry knowledge was the forming, the restoration of the destroyed agriculture after imperialist and civil war continued, the existing small private and the collective livestock was in need of qualified assistance for creating the normal conditions of farm animal keeping and feeding, providing care of them ${ }^{13}$.

The introduction of the rules and norms of farm animal hygiene into production became possible in the 20 's of the $20^{\text {th }}$ century. However, during these years research work in the field of hygiene of farm animals was conducted less intensively than the promotion of zoo-hygienic knowledge through books, pamphlets, posters, various mass courses and schools. Domestic scientists M.F. Ivanov (1922), I.A. Dobromyslov (1924) and G.I. Gurin (1927) published the textbooks and teaching manual, which played an important role in the training of students of higher educational institutions and specialists in the field of farm animal hygiene and

\footnotetext{
${ }^{11}$ Артюх И. А. Развитие ветеринарной науки на Украине. Ветеринария. 1954. № 1. С. 10-16.

${ }^{12}$ Бородай I. С. Теоретико-методологічні основи становлення та розвитку вітчизняної зоотехнічної науки. Вінниця, 2012. 416 с.

${ }^{13}$ Аликаев В. А. Зоогигиена. Москва : «Колос», 1976. 256 с.
} 
veterinary medicine. Thus, in particular, I.A. Dobromislov defined farm animal hygiene as a science that studies the causes and conditions affecting animal health, preventing diseases on basis appropriate care and keeping, and developing measures to improve of animal resistance. G.I. Gurin in his book «Зоогигиена. Уход за сельскохозяйственными животными» (1927) defines farm animal hygiene as a science whose main task is to prevent animal diseases. It addresses the tasks of developing measures for the prevention and control of diseases, namely isolation, disinfection, quarantine, diagnostics, therapeutic vaccinations and insurance of cattle ${ }^{14}$.

A special need for obtaining scientifically substantiated data on the animal keeping and care appeared during the period of the so-called socialist reconstruction of agriculture, which covered 1929-1937, the organization of socialized livestock and the creation of large specialized livestock farms, that required the development of standards for the construction of the livestock premises, water supply and placement of animals, care for them, their production exploitation, raising of young animals, etc.

In this period intensive research work and organization of the farm animal hygiene departments at veterinary research institutes and research stations, in particular at the All-Union Institute of Experimental Veterinary Medicine, the All-Union Scientific Research Institute of Animal Husbandry, the Ukrainian Institute of Experimental Veterinary Medicine, the Poltava Scientific Research Institute of Pigs, Leningrad ScientificResearch Veterinary Institute, Kazan Veterinary Research Institute, Omsk Scientific Research Veterinary Institute, Belorussian, Voronezh, Rostov, Sverdlovsk veterinary research stations, some zootechnical research institutions and others, were characteristic trend ${ }^{15}$.

The research on the field of farm animal hygiene were also carried out by the departments of higher educational institutions. In the veterinary and zootechnical universities the farm animal chairs were organized in the early 30's. During this period, textbooks on farm animal hygiene by A.K. Skorohodko (1930), F.M. Ozhogin (1932), A. Ozerov (1934), V.A. Alikaiev (1936) and also a large number of popular science literature for institutes and technical schools were published. The rules for the

\footnotetext{
${ }^{14}$ Гурин Г. И. Зоогигиена. Уход за сельскохозяйственными животными. Москва: «Новый агроном», 1927. $197 \mathrm{c}$.

${ }^{15}$ Всесоюзный институт экспериментальной ветеринарии ВАСХНИЛ : краткий очерк / сост. Ф. А. Терентьев ; ред. Я. Р. Коваленко. Москва, 1958. 28 с.
} 
keeping of all types and age groups of farm animals with the regulation of the minimum required for zootechnical, zoo-hygienic, veterinary and sanitary measures were proposed. The teaching of farm animal hygiene at that time became one of the main parts of the programs for the production training of livestock farmers ${ }^{16}$.

On September 14-16, 1936, an expanded meeting of the Scientific Council of All-Union Institute of Experimental Veterinary Medicine on the issues of farm animal hygiene took place. This meeting, as noted by A.K. Skorohodko, was an important event in organizational and thematic format, which showed that research work on farm animal hygienic, despite the small number of staff, has increased significantly. There were reports and speeches on microclimate and livestock hygiene, feeding and drinking hygiene, hygiene of keeping and exploitation, and hygiene of reproduction and breeding of young animals ${ }^{17}$.

On this basis the Scientific Council formed the first norms of the temperature-humidity regime in the heating and non-heating premises, the introduction of dried carrots and dried yeast in the ration of pigs in order to increase their resistance to the infectious and gastrointestinal diseases. It suggested the mineral supplements for dry cows and piglets with indication of the corresponding equivalents of acids to alkali, phosphorus to calcium, sodium and potassium. It was noted that for the sanitary-hygienic purpose, it is necessary to develop a number of measures to improve the quality of water, and, above all, the publication in the legislative procedure of the rules of sanitary protection of water supply sources in the livestock farms, as well as the preparation of a special instruction on the keeping and exploitation of livestock premises for the creation optimum conditions of the air mode in the stall period.

In December 1936 in Gorky, the Seventh plenum of the Veterinary Section All-Union Agricultural Academy of Sciences named after V. Lenin was held, which was completely devoted to the issues of farm animal hygiene. The state of scientific and research work on farm animal hygiene was evaluated. The harmful effects of high humidity on the organism of farm animals, especially at low temperatures, have been established. It was

\footnotetext{
${ }^{16}$ Коропов В. М. Из истории ветеринарного образования в России. Ветеринария. 1947. № 9. C. $7-10$.

${ }^{17}$ Всесоюзный институт экспериментальной ветеринарии ВАСХНИЛ : краткий очерк / сост. Ф. А. Терентьев ; ред. Я. Р. Коваленко. Москва, 1958. 28 с.
} 
proved that to prevent high humidity should be used ventilation in combination with heating premises or blowing heated air.

The plenum also noted a number of shortcomings: insufficient study of the problems of farm animal hygiene despite the rapidly growing needs of animal husbandry; lack of planning of zoo-hygienic subjects in scientific research institutions; underestimation of farm animal hygiene as a science and, as a result, a weak development of the network of farm animal hygiene departments at peripheral veterinary research stations; insufficient number of hours in the course of farm animal hygiene in the curriculum of universities, etc. ${ }^{18}$.

During the Second World War development of farm animal hygiene issues was suspended, the lack of staff in research institutions and higher educational institutions was tangible. Despite this, domestic scientists in the field of farm animal hygiene have gained some achievements. The most important of these were the refinement and definition of goals and objectives of farm animal hygiene studies, its formation as a branch of research and compulsory discipline in veterinary and zootechnic educational institutions ${ }^{19}$.

\section{Development of Hygiene of Farm Animals in Ukraine in the Second Half of the 40's - at the Beginning of the $21^{\text {th }}$ Century}

The period 1947-1953 is characterized by the expansion of scientific research on farm animal hygiene and the implementation of its recommendations in the production of livestock products. For this period, livestock specialists are widespread use of scientifically substantiated measures for the care, keeping and feeding of farm animals. For the first time, the norms of building designing for livestock and veterinary establishments, as well as «Примерные зоотехнические и ветеринарные правила по уходу, кормлению, содержанию и воспроизводству сельскохозяйственных животных и птицы» (1950) were issued ${ }^{20}$.

Domestic scientists have conducted a research on the effects of climatic factors and gas composition of air on the organism of farm animals. V.A. Alikaiev, M.V. Kalitaiev, B.G. Levitskyi, A.K. Skorohodko have established the dynamics and character of temperature changes, humidity in

\footnotetext{
${ }^{18}$ Бородай I. C. Теоретико-методологічні основи становлення та розвитку вітчизняної зоотехнічної науки. Вінниця, 2012. 416 с.

${ }^{19}$ Аликаев В. А., Бурксер Г. В. Зоогигиена. Ветеринария. 1977. № 12. С. 33-35.

${ }^{20}$ Аликаев В. А. Зоогигиена. Москва : «Колос», 1976. 256 с.
} 
the premises. G.I. Alekseiev, A.A. Kudriavtsev investigated the influence of climatic factors on metabolism and productivity, A.P. Zozulia, A.K. Skorohodko, A.O. Shylov studied the reactions of the organism to the change of climatic factors and the importance of these factors in the etiology of the farm animal diseases. The dynamics of changes in the gas composition of air in the buildings was studied by V.A. Alikaev, F.A. Ishchukov, P.E. Kravchenko, Ye.E. Shumakovych and others.

The performed research on the air environment of farm animals made it possible to develop standards for temperature, humidity, velocity and air composition in the buildings for different species and age groups, to formulate zoo-hygienic requirements for the construction of livestock constructions $^{21}$.

The research of domestic scientists by M.M. Saltykov, V.A. Zingovatov have proved the efficiency of ventilation systems of stalks, barns, pig farms, and sheepfolds. A.A. Kudryavtsev, V. E. Parunin, V.P. Ryzhkov, M. M. Saltykov have provided physiological substantiation and calculations of requirements for the air volume of ventilation, V.V. Bokov, M.V. Kalitaev, E.I. Rybchinskyi tested new ventilation systems and installations, V.A. Alikaiev, V.M. Pichugin, T.K. Starov, D.P. Troyanovskyi established the norms of the space cubic and the methods of the most hygienic placement of farm animals. The samples of interior equipment of the buildings were proposed in accordance with the requirements of farm animal hygiene by G.K. Grigoriev, Ye.I. Rybchinskyi and other scientists. The research by A. Orlov, A. Sidorovskyi, A.K. Skorohodko, V.A. Skvortsov, M. F. Tommé, who studied zoo-hygienic properties of various litter materials, have a significant scientific significance.

In the postwar years, the questions of the evaluation of the quality of feed were studied comprehensively by I.A. Gusin, M.A. Golubev, A.K. Skorohodko, P.Y. Kravchenko, A.K. Reinfeld, the influence of mineral and vitamin feeding of farm animals on the increase of resistance organism to diseases - by V.A. Alikaiev, B.G. Levitskyi, A.P. Onegov, I.F. Soldatenkov, the dietary prophylaxis of farm animal diseases - by M.I. Aizatullov, B.G. Levitskyi, A.P. Onegov and others. Some data on the hygiene of feeding, obtained by domestic scientists, made it possible to significantly prevent diseases of the digestive system and feed poisoning,

\footnotetext{
${ }^{21}$ Калитаев М. В. О некоторых проблемах развития зоогигиены. Ветеринария. 1966. № 1. С. 90-92.
} 
to organize dietary prophylaxis of various diseases and to use the influence of full feeding to increase the resistance of the organism of farm animals to infectious diseases ${ }^{22}$.

System research on the sanitary state of water supply sources was initiated by M.A. Golubev, F.A. Ishukova, K.A. Kotliar, K.A. Pokrovskyi, V.A. Tsingovatov and others. Quantitative norms of water supply of livestock farms for maintenance of the necessary sanitary condition were developed by K.M. Vasilieva, D.V. Yelpateievskyi, A.P. Markushin, V.P. Fediushin, while the issues of zoo-hygienic organization of water supply of farm animals by V.K. Bauman, C.V. Ivanitskyi, P.F. Kuiatkin and others. Some data on hygiene of water supply and water drinking of animals have found industrial application.

Particularly valuable researches have carried out on the hygiene of breeding young farm animals. V.A. Alikaiev, I.A. Lebedev, V.F. Matusevich, P.D. Pshenychny, A.S. Solun have determined the importance and influence of the conditions of feeding and keeping of mothers during pregnancy on their resistance to diseases and the development of the born young. A.A. Kudriavtsev, P.Ye. Kravchenko, A.K. Skorohodko, T.K. Starov have investigated the influence of climatic factors on the state of health, growth and development of young farm animals. A. Aizatulov, V.A. Alikaiev, A.P. Onegov, A.K. Skorohodko, A.P. Yurmalat have used effective hygienic methods and norms of young animal feeding. The issues on keeping and newborn animal care were subject of scientific research of P.P. Vishnevsky, F.A. Ishukova, V.S. Litash, P.M. Tikhonov ${ }^{23}$.

The scientific researches and production observations on animal care and their exploitation became the basis for the introduction of a number of new animal husbandry techniques into the practice of livestock farms. Among the main scientific studies of this field should be noted works by F.K. Borysovych, K.N. Vasiliev and A.K. Skorohodko on the rationalization of animal skin care; V.A. Alikaiev, S.F. Mironov, N.F. Myshkin, P.N. Tikhonov, D.P. Troianskyi on the hygiene of milking (including mechanical type); V.A. Alikaiev, F.A. Amfiteatrov, V.M. Onisimov, M.M. Shpaier on the hygienic normalization of harnesses and methods of use of working animals. Professors V.A. Alikaiev and P.T. Lebedev first proposed norms for the content of carotene, phosphorus

\footnotetext{
${ }^{22}$ Муромцев С. Н. О новых задачах в работе по зоогигиене. Ветеринария. 1949. № 7. С. 4.

${ }^{23}$ Артюх И. А. Развитие ветеринарной науки на Украине. Ветеринария. 1954. № 1. С. 10-16.
} 
and calcium in serum of animals and fodder, that played an important role in organizing extensive studies on the diagnosis of metabolic disorders in farm animals and assessments nutritional value of feed in $1953-1956^{24}$.

A new period in the development of farm animal hygiene began in the 60 's of the 20th century. Its new tasks consisted in the creation of a material and technical base, the transition to a new technology of animal husbandry, the implementation of integrated mechanization, automation of work on animal care, the introduction of group methods of keeping, chemicalization and electrification of agriculture, irrigation and melioration of land and specialization of production processes. Under such conditions, farm animal hygiene was directed on studying the modes of animal keeping in the changed conditions of livestock industry, improving methods of zoo-hygienic assessment of the new systems and methods of keeping, clarifying the norms of the construction of farms and premises, substantiating the farm animal hygienic norms of feeding and keeping, caring for them, finding out the causes and the laws of increasing and reducing the resistance of animals to diseases and other issues ${ }^{25}$.

These issues were considered in the recommendations of the Ministry of Agriculture of the USSR «Основные условия и требования при переводе крупного рогатого скота на беспривязное содержание» (1963), «Рекомендации по машинному доению коров» (1964), «Рекомендации по повышению эффективности крупногруппового содержания свиней» (1964), as well as in the norms of technological design of livestock farms and veterinary facilities (1966-1967), rules of testing and exploitation of the ventilation systems (1959) and methodical instructions on air ionization in livestock buildings (1965). In these years, the effective means of saving and automatic control of optimal microclimate in new modern buildings have developed, issues on zonal specificity of the conditions of keeping and evaluation of the means of mechanization of animal care processes have solved ${ }^{26}$.

Domestic scientists have tested the principle of the allocation of "white" and "black" zones on the territory of the farms, which had different conditions and possibilities of shops of the different zones with

\footnotetext{
${ }^{24}$ Аликаев В. А. Достижения советской зоогигиены и ее дальнейшие задачи. Гигиена сельскохозяйственных животных: тр. XXIX пленума ветеринарной секции Академии. Москва: Сельхозгиз, 1950. С. 8-22.

${ }^{25}$ Калитаев М. В. О некоторых проблемах развития зоогигиены. Ветеринария. 1966. № 1. С. 90-92.

${ }^{26}$ Аликаев В. А. Зоогигиена. Москва : «Колос», 1976. 256 с.
} 
outdoor lighting. They have tested the zoo-hygiene breaks between some shops and buildings in different zones and in relation to farms with different composition and number of farm animals. F.F. Porokhov, S.S. Abramov, S. Stoyanovskyi, I. Melnyk have received satisfactory results on the regulation of the impact on the organism of the animals of the environment for the use of ultraviolet irradiation. S.I. Plyaschenko, V.I. Cherniak, V.S. Dolgov, K.V. Melnikov have developed ways of manure removal on the basis of the application of lattice-slit floor, hydrosmiling, methods of manure disinfection and sewage. The name of I.F. Khrabustovskyi is related to studies on the resistance of animal organisms. He is co-author of the textbook «Гигиена сельскохозяйственных животных», which was reissued three times ${ }^{27}$.

In 1971, in Budapest took place the first congress of the International Zoo-Hygienic Society. In the subsequent society held congresses and working symposiums, which considered the achievements of zoohygienists in most countries of the world. In the 70's - 80's, domestic scientists have conducted an experimental and natural assessment of the main types of buildings for different species of the animals and poultry. G.K. Volkov, A.T. Semeniuta, I.F. Khrabustovskyi theoretically substantiated and tested reliable sanitary breaks in poultry farms and complexes, zoning of the territory of the farm, norms of veterinary and sanitary protection, etc. ${ }^{28}$.

Scientists of the All-Union Institute of Experimental Veterinary Medicine K.P. Andreiev, S.D. Pavlov, T.I. Yanovich have conducted research on farm animal protection from ticks. I.I. Arkhangelskyi, N.A. Spesivtsev, I.P. Danilenko have proposed means and methods for increasing the sanitary quality of milk and feed. M.M. Komarov, A.A. Polyakov, V.S. Yarnych had developed and implemented means for mechanization of sanitary, hygienic, disinsection, disinfection works on the livestock farms ${ }^{29}$.

In this period an important role in the development of farm animal hygiene was played by academician K.I.Scriabin. Developing helminthiasis control, he has pointed to the need to strictly adhere to the

\footnotetext{
27 Аликаев В. А., Бурксер Г. В. Зоогигиена. Ветеринария. 1977. № 12. С. 33-35.

${ }^{28}$ Зоогігієна i профілактика захворювань сільськогосподарських тварин/ за ред. I. Ф. Храбустовського, В. К. Чернуха. Київ: Урожай, 1981. 224 с.

29 Всесоюзный институт экспериментальной ветеринарии ВАСХНИЛ : краткий очерк / сост. Ф. А. Терентьев ; ред. Я. Р. Коваленко. Москва, 1958. 28 с.
} 
principles of farm animal hygiene, since resistance to helminths can be enhanced by rational care of animals and their full feeding ${ }^{30}$.

Domestic scientists have investigated the quantitative and qualitative (typical) characterization of the microflora inhabiting livestock buildings, developed the methods of microbiosis control, it has a fundamental importance for modern farms and complexes. In particular, Yu.M. Markov has found new, generalizing approaches and tests to assess the conditions of animal keeping, namely the parameters of the microclimate, developed its comprehensive score (1988). Other scientists have suggested recommendations for the use of winter and summer systems of animal keeping, methods of litter use and manure storage and disinfection. The works relating to the study of the sanitary quality of feed and its toxicological evaluation, the impact of full feeding on the increase of resistance of farm animals, especially for young animals, have special practical importance ${ }^{31}$.

In the post-Soviet period, scientists in the field of farm animal hygiene have received valuable data of biogeochemical zones with a shortage or excess of macro- and microelements in soil, feed and water, the emergence of epizootic diseases in farm animals and the development of effective measures for their prevention; introduced a new direction in farm animal hygiene - dietary feeding for the prevention of a number of diseases and diet therapy for the treatment of sick animals. These works are basis for introducing into practice the control of the full value of animal feeding by the study of feeds on the content of protein, minerals and carotene, as well as the state of protein, mineral and vitamin metabolism in productive animals ${ }^{32}$.

Ukrainian scientists have performed a research to find out the norms of the light regime in the premises, the effect of natural and artificial light on reproductive functions, productivity and resistance of farm animals, as well as the use of their ultraviolet and infrared radiation, ionization in the premises in order to stimulate growth of young animals, increase their productivity, prevent diseases and improvement of the sanitary-hygienic regime of stool keeping.

30 Зоогігієна і профілактика захворювань сільськогосподарських тварин/ за ред. І. Ф. Храбустовського, В. К. Чернуха. Київ: Урожай, 1981. 224 с.

${ }^{31}$ Чорний М. В. Зоогігієна : наука і навчальна дисципліна. Ветеринарна медицина Украйни. 1998. № 7. С. 32-33.

${ }^{32}$ Бородай I. C. Теоретико-методологічні основи становлення та розвитку вітчизняної зоотехнічної науки. Вінниця, 2012. 416 с. 
They studied the effects on the body of such factors: natural and artificial radiation, noise, electric and magnetic fields, ozone. Thanks to the research of Ukrainian scientists, a zoo-hygienic and veterinary-sanitary assessment of the most common technologies in cattle, pig, sheep, sheep, horse breeding, poultry, fur and pond fish farming and beekeeping was conducted; the influence of hypodynamics as one of the negative consequences of a number of intensive technologies on the functional state of the organism of animals was revealed. The study of technological, transport, climatic and other stresses, which often have a negative impact on animals, is also important. On the basis of the obtained data, they have proposed methods of disease prevention and control $^{33}$.

Ukrainian scientists have developed veterinary measures and included them in technology of the modern farms, most of which have a preventive or so-called hygienic and veterinary-sanitary character in particular the conditions for selection, transportation, displacement of animals, sectionalization of buildings, including quarantine, its preparation, use, principles of completing, cleaning and disinfection, etc. They have worked out improved technology options in both industrial and breeding livestock, where for the first time began to pay attention to the natural resistance of animals to diseases.

In the modern farms, the possibility of an individual approach, care and clinical examination of animals is practically excluded. The method to determine the clinical healthy herd proposed by Professor I. Kalikh in 1995 is widely used now. It is based on not only determining the main parameters of the clinical status of each animal, but also the ability of all animals of the herd to produce products in accordance with their genetic potential $^{34}$.

At present, farm animal hygiene develops new scientific direction on hygiene and biochemistry of forages in order to increase the their productivity, obtaining products with high dietary properties, searches for promising directions and effective ways to reduce ecological pressures on the environment of livestock industry, technical and economic justification of local raw material base use for agricultural construction ${ }^{35}$.

\footnotetext{
33 Красій В. В. Роль і значення дисципліни «гігієна тварин» у підготовці сучасних фахівців тваринництва. Науковий вісник Національного аграрного університету. Київ, 1998. Вип. 12. С. 32-36.

${ }^{34}$ Чорний М. В. Зоогігієна : історія, проблеми і завдання курсу при підготовці зооветспеціалістів. Науковий вісник Національного аграрного університету. К, 1998. Вип. 12. С. 26-32.

${ }^{35}$ Чорний М. В. Зоогігієна : наука і навчальна дисципліна. Ветеринарна медицина Украӥни. 1998. № 7. C. $32-33$.
} 
In the future, it is necessary to continue theoretical, methodological and applied research on farm animal hygiene. It should be combined with zoo-ecology and veterinary sanitation, as integral components. All of them have a practical prophylactic orientation, and only in a complex able to carry out current and new, constantly emerging, orders of animal husbandry practices.

\section{CONCLUSIONS}

1. The formation and development of domestic farm animal hygiene was carried out in stages. Its becoming in the $18^{\text {th }}-19^{\text {th }}$ centuries was provided with scientific works of domestic scientists M.G. Livanov, S.M. Khodetsky, I.P. Popov, G.I. Svetlov, M.P. Chyrvinskyi and others who studied the influence of animal breeding and feeding conditions on their performance and health. The forerunner of its in the 20's -30 's of the 20th century was the socialization of animal husbandry and the organization of large specialized livestock farms, that required the development of standards for the construction of livestock buildings, water supply and placement of farm animals, care for them, their production exploitation, raising of young animals, etc.

2. The development of these issues ensured with the organization of farm animal hygienic chairs at the branch universities and zoo-hygienic laboratories. In the Soviet era, the domestic scientists have proposed some priority developments on farm animal hygiene of keeping, feeding and care, sanitary and hygienic standards, norms for the construction of animal premises, etc. V.A. Alikaiev, P.T. Lebedev, B.G. Levytskyi, A.P. Onegov, A.K. Skorohodko, I.F. Khrabustovskyi, Yu.M. Markov made a decisive contribution in the formation and development of scientific principles of zoo-hygiene. In the post-Soviet period, zoo-hygiene developed in complex with zoo-ecology and veterinary sanitation as integral components that have a practical prophylactic orientation, and able to perform existing and new, constantly emerging, orders of animal husbandry practices.

\section{SUMMARY}

The purpose of the article is to highlight the main directions and periods of the establishment and development of domestic zoo-hygiene, generalize the most significant achievements of the scientists in the development of hygienic norms of feeding and drinking, keeping and care 
of animals. The research is based on the comprehensive use of general scientific, special historical methods, source analysis. The historiographic analysis of this problem showed that certain aspects of the formation and development of zoo-hygienic research in Ukraine were developed by V.A. Alikaev, M.V. Demchuk, M.V. Kalitaev, V.M. Koropov, V.V. Krasiy, M.V. Chornyi, I.S. Borodai and others.

It is proved that among the complex of agricultural sciences, which promote the improvement of tribal resources, a special place belongs to zoo-hygiene science, the main task of which is to provide health care and high productivity of farm animals, obtaining products with high dietary properties, finding effective ways to reduce ecological pressures on the environment of the livestock industry.

The author shows that the origin of zoo-hygiene in the $18^{\text {th }}-19^{\text {th }}$ centuries was provided by the emergence of scientific works of domestic scientists M.G. Livanov, S.M. Kodetsky, I. Popov, G.I. Svetlov, M.P. Chyrvinsky and others who studied the influence of breeding and feeding conditions on productivity indices and state of animal health.

The establishment of zoo-hygiene in the 20-30's of the 20th century contributed to the socialization of animal husbandry and the organization of large specialized livestock farms, that required the development of standards for the construction of livestock buildings, water supply and placement of animals, care for them, their production exploitation, raising young animals, etc. The development of these issues was ensured with the organization of zoo-hygienic chairs at branch higher educational institutions and zoo-hygienic laboratories. In the Soviet era, domestic scientists have proposed same priority developments on hygiene of animal keeping and feeding, care, sanitary and hygienic standards and norms for the construction of the premises for animals, etc. The V.A. Alikayev, P.T. Lebedev, B.G. Levytsky, A.P. Onegov, A.K. Skorohodko, I.F. Khrabustovsky, Yu.M. Markov et al. made a decisive contribution in the establishment and development of scientific principles of zoo-hygiene in this period.

It was established that in the post-Soviet period, zoo-hygiene is developed simultaneously with zoo-ecology and veterinary sanitation as a related component which has a practical prophylactic orientation and able to fulfill existing and new orders of livestock practices in the complex. At present, priority is given to the development of such scientific direction 
as the study of feed hygiene and biochemistry for improving the productivity of farm animals, the production of products with high dietary properties, active search for promising directions and effective ways to reduce ecological pressures on the environment objects of the livestock industry, ecological, technical and economic justification of using a local raw material base for agricultural construction.

\section{REFERENCES}

1. Аликаев В. А. Зоогигиена. Москва : «Колос», 1976. 256 с.

2. Аликаев В. А. Достижения советской зоогигиены и ее дальнейшие задачи. Гигиена сельскохозяйственных животных: тр. XXIX пленума ветеринарной секции Академии. Москва : Сельхозгиз, 1950. C. 8-22.

3. Аликаев В. А., Бурксер Г. В. Зоогигиена. Ветеринария. 1977. № 12. С. 33-35.

4. Артюх И. А. Развитие ветеринарной науки на Украине. Ветеринария. 1954. № 1. С. 10-16.

5. Бородай I. С. Теоретико-методологічні основи становлення та розвитку вітчизняної зоотехнічної науки. Вінниця, 2012. 416 с.

6. Всесоюзный институт экспериментальной ветеринарии ВАСХНИЛ : краткий очерк / сост. Ф.А. Терентьев ; ред. Я. Р. Коваленко. Москва, 1958. 28 с.

7. Гурин Г. И. Зоогигиена. Уход за сельскохозяйственными животными. Москва: «Новый агроном», 1927. 197 с.

8. Демчук М. В. Основні досягнення і перспективи розвитку гігієни тварин в Україні (в світлі розвитку наукових ідей професора А.К. Скороходька). Науковий вісник Національного аграрного університету. К, 1998. Вип. 12. С. 25-28.

9. Зоогігієна і профілактика захворювань сільськогосподарських тварин / за ред. І. Ф. Храбустовського, В. К. Чернуха. Київ: Урожай, 1981. $224 \mathrm{c}$.

10. Калитаев М. В. О некоторых проблемах развития зоогигиены. Ветеринария. 1966. № 1. С. 90-92.

11. Коропов В. М. Из истории ветеринарного образования в России. Ветеринария. 1947. № 9. С. 7-10. 
12. Красій В. В. Роль і значення дисципліни «гігієна тварин»у підготовці сучасних фахівців тваринництва. Науковий вісник Національного аграрного університету. Київ, 1998. Вип. 12. С. 32-36.

13. Муромцев С. Н. О новых задачах в работе по зоогигиене. Ветеринария. 1949. № 7. С. 4.

14. Чорний М. В. Зоогігієна: наука i навчальна дисципліна. Ветеринарна медииина України. 1998. № 7. С. 32-33.

15. Чорний М. В. Зоогігієна: історія, проблеми і завдання курсу при підготовці зооветспеціалістів. Науковий вісник Національного аграрного університету. К, 1998. Вип. 12. С. 26-32.

\section{Information about the author:} Bey R. V.,

Doctor of Historical Sciences, Senior Researcher, Chief Scientist of the Scientific Bibliography and Biography Study, National Scientific Agricultural Library of NAAS 10, Heroiv Oborony St., Kyiv, 03127, Ukraine 


\section{FORMATION AND DEVELOPMENT OF THE SCIENCE OF ANIMAL FARM FEEDING (THE SECOND HALF OF 19th - EARLY OF THE 21st CENTURIES)}

\section{Borodai I. S.}

\section{INTRODUCTION}

At the present stage, the guarantor of food security and stability of the national economic complex of Ukraine is the further development of animal husbandry, which, while meeting the needs of the population in food, contributes to the preservation of the health of the nation. Basis for raising the competitiveness of livestock, the growth of the export potential of the country is the feeding of farm animals, which encompasses, in the first instance, theoretical developments and technological methods of providing a rational nutrition that promote normal growth and development, achievement of the genetically determined level of productivity of farm animals and the necessary quality of products, health and a high reproductive ability for eco-friendly feed consumption

Ukrainian scientists have developed the basics for determining the nutritional value of forages, balanced feeding standards and feed rations for different types of farm animals, optimized feeding techniques and organization, and so on. The achievements of scientists in the field of feeding farm animals show the real cultural potential of the Ukrainian community, its ability to self-representations in the world of science and information space. That is a powerful theoretical and methodological basis for developing a further strategy for animal husbandry development in Ukraine.

During the statehood in Ukraine, there were no fundamental researches, which would comprehensively cover the formation and development of scientific foundations for the farm animal feeding as a basis for increasing their productivity, profitability of the livestock industry. It determines the theoretical and practical significance of our research.

On the basis historiographical analysis it was established that certain issues of the formation and development of scientific knowledge about the feeding of farm animals are covered in the scientific works of 
G. Bogdanov ${ }^{1}$, M. Tomme ${ }^{2}$, V. Kandyba ${ }^{3}$, in our previous publications ${ }^{4}$. The aim of the research is to integrate scientific and historical analysis and to allocate periods of formation and development of farm animal feeding in the context of the world industry scientific thought. General scientific and interdisciplinary methods used to solve research tasks. Particular attention paid to special historical methods, source analysis. The source base of the study includes a complex of diverse documents, the basis of which are archival materials.

The article is prepared in accordance with the tasks of the state budget theme 0116U002102 "Scientific-organizational and regulatory bases of innovative activity in the system of agrarian science: theoretical and methodological, historical and scientific studies, archival, bibliographic aspects of research".

\section{Prerequisites for the Forming of Scientific Concepts of Farm Animal Feeding}

As the analysis showed, the prerequisite for the formation and development of the science of farm animal feeding was the development of foreign and domestic scientists in the fields of physics, chemistry, physiology, biology, biochemistry and other related sciences, which formed its theoretical and methodological basis. In particular, the discovery of oxygen by Pristlie and Sherl, clarifying its significance for life by Lavoisier made it possible to formulate the notion of the organism and its livelihoods. The role of protein was first investigated by F. Maghandi in 1816, initiating the development of scientific foundations of protein feeding of animals. The animal need in mineral substances was substantiated by O. Rubets. M. Lunin and K. Funk have established the presence of vitamins in products that have became indispensable in the feeding of farm animals ${ }^{5}$.

The scientific schools of domestic physiologists and biochemists also made a decisive contribution to the formation of the theory of farm

\footnotetext{
${ }^{1}$ Богданов Г. А. Кормление сельскохозяйственных животных. Москва, 1990. 624 с.

${ }^{2}$ Томмэ М. Ф. Кормление сельскохозяйственных животных. Больщая Советская Энииклопедия. 3-е изд. Москва, 1973. Т. 13. С. 530-533.

${ }^{3}$ Кандиба В. М. Досягнення вчених інституту тваринництва УААН в розвитку науки про повноцінну нормовану годівлю сільськогосподарських тварин і пріоритетні напрями досліджень у сучасних умовах. Науково-технічний бюлетень. Харків, 2009. Вип. 100. С. 269-277.

${ }^{4}$ Бородай І. С. Теоретико-методологічні основи становлення та розвитку вітчизняної зоотехнічної науки. Вінниця, 2012. 416 с.

${ }_{5}^{5}$ Богданов Г. А. Кормление сельскохозяйственных животных. Москва, 1990. 624 с.
} 
animal feeding. In particular, the problems of physiology of feeding were developed in the research by I. Pavlov and his pupils who discovered the mechanism of digestion and the most favorable conditions for the passage of this process. I. Sechenov substantiated the connection of the organism with the external environment. During the $19^{\text {th }}$ - early $20^{\text {th }}$ centuries German scientists made decisive contribution in formation of the theoretical foundations of the science of farm animal feeding. Its founder was A. Teyer, who formulated the theory of "hay equivalents". In the book "Basis of rational agriculture" (1809), he first expressed farm animals need in feeds in uniform rules, while its nutritional value brought in the calculation of hay. He has developed feed tables and norms for fattening cattle ${ }^{6}$.

The intensive development of organic chemistry in the $19^{\text {th }}$ century contributed to the study of the chemical composition of plants and the theory of nutritional assessment of feed. In 1836, J. Bussengho proved the importance of feed nitrogen and offered to take its percentage for the nutritional value of feed. In the middle of the nineteenth century. Yu. Libich divided all the substances of feed into plastic and respiratory, substantiated the role of proteins, carbohydrates and fats in feeding. In 1866, Pettencofer and K. Voith, conducting experiments under conditions of nitrogen balance, formulated the concept of nitrogen balance. G. Gruven determined the rates of dry organic matter, protein, fat and carbohydrates for different types of farm animals, began to evaluate the nutrition content of feeds. V. Henneberg and F. Stomann proved the importance of the assimilated part of the feed compared to the nutrient, due to this E. Wolf developed the nutrient tables of the feed digestible nutrients ${ }^{7}$.

In assessing the nutrition of feeds, much attention was paid to the method developed by $\mathrm{O}$. Kelner. The scientist proposed to assess the nutrition of the feed in starch equivalents, based on the fact that $1 \mathrm{~kg}$ of starch fed to adult oxen, can provide an average of $0.25 \mathrm{~kg}$ of delayed fatty tissues. In assessing the nutrition of feed and rationing of feeding a significant contribution also made by G. Armsby. He developed a scheme of energy balance of animal organism, introduced the concept of gross,

\footnotetext{
${ }^{6}$ Бородай I. С. Теоретико-методологічні основи становлення та розвитку вітчизняної зоотехнічної науки. Вінниця, 2012. 416 с.

${ }^{7}$ Томмэ М.Ф. Кормление сельскохозяйственных животных. Большая Советская Энциклопедия. 3-е изд. Москва, 1973. Т. 13. С. 530-533.
} 
digestible, physiologically useful and pure energy, proposed to estimate the total nutrition of feed in units of pure energy deposited in the body in the form of protein and fat. At the same time, N. Fjord and N. Hanson used a Scandinavian feed unit for assessing the nutritional value of feed, for which they took $1 \mathrm{~kg}$ of dry barley, or 0.72 of starch equivalent ${ }^{8}$.

In 1914, L. Mendel and T. Osborne discovered the need in essential amino acids for laboratory animals, that created the basis for the development of norms for its consumption for farm animals. Since then, research on mineral nutrition has become systematic, its resulted in the determination of the indispensability of about 70 substances, elements, factors in feeding animals. Since then, research on mineral nutrition has become systematic, its result was the determination of the irreplaceability of about 70 substances, elements, factors in animal feeding 9 .

In the Russian Empire at the end of the $19^{\text {th }}$ - early $20^{\text {th }}$ centuries scientists used fodder rules for various types of farm animals developed by German scientists. Poor funding and technical equipment of research institutions did not contribute to the establishment and development of this scientific direction.

According to the results of our research, on the Ukrainian lands the issues of farm animal feeding was raised for the first time by agricultural societies. So, the Imperial Society of Agriculture in Southern Russia developed the issues of feeding and drinking merino sheep, the best owners were given a premium for well-fed cattle. Poltava Agricultural Society carried out the first experiments on fattening pigs, on its basis they developed technologies of their bacon fattening. Kharkiv and Kyiev associations of agriculture and agricultural industry in the late $19^{\text {th }}$ - early $20^{\text {th }}$ centuries conducted a series of studies on control of fattening of cattle, the influence of the feed rations on the level of livestock, and so on.

As one of the most important research on feeding farm animals conducted in this period in the Ukrainian lands, we consider the master's thesis by P. Shyrokych, who studied the chemical composition of the 139 samples of winter wheat and 45 rye straw ${ }^{10}$. The second important work was the analysis of 150 samples of forage plants, conducted at the Poltava Researching field in 1900-1908, which took into account the influence of the terms of its harvest on yield and chemical composition.

\footnotetext{
${ }^{8}$ Ханссон Н. Кормление сельскохозяйственных животных. Москва: Сельхозгиз, 1936. 124 с.

${ }^{9}$ Богданов Г. А. Кормление сельскохозяйственных животных. Москва, 1990. 624 с.

${ }^{10}$ Особова справа П. О. Широких // Державний архів м. Києва. Ф. 18. Оп. 2. Спр. 290. 80 арк.
} 
In our opinion, it is interesting to study the research by F. Rurikov of the chemical composition of steppe pirache hay, which includes the data of analysis of 36 samples of pyrite with an admixture of other herbs collected in the steppe zone of the Ukraine. The achievement of the scientist was also the first method of studying local feeds ${ }^{11}$.

At the beginning of the $20^{\text {th }}$ century the research of the nutritional and chemical composition of local feeds, its influence on the formation of farm animal productivity in various natural-climatic zones on Ukrainian lands were also conducted by I. Bel'govsky, O. Bondarenko, I. Kalugin, A. Redkin, I. Shirokykh and others.

As the analysis showed, during this period, domestic scientists had a priority in solving some problems of farm animal feeding. In our opinion, especially important were the M. Chyrvinskyi`s developments, who in 1882 proved the possibility of formation of fat from carbohydrates, that contributed to the improvement of systems for assessing the productive effect of feed. Another significant achievement of the scientist was the substantiation of the influence of the level of feeding on the growth and development of animals. It should be noted that M. Chyrvinskyi was the first who raised the question of the need of farm animal feeding in Russia at the First Congress of Agricultural Experimental Affairs in $1901^{12}$.

No less important achievement of this period was the experimental establishment of direct and indirect participation of protein feed in the formation of fat in animal body by Ye. Bogdanov in 1903-1908. The scientist has shown that along with the overall nutritional value of the food, it is necessary to consider the protein and vitamin ones. He developed the doctrine of normalized feeding, taking into account the physiological state of animals, ecological and economic characteristics of the livestock sector of various natural and climatic zones of the country ${ }^{13}$.

The decisive role of feeding in the breed creation of farm animals has been proved by the scientific work of M. Ivanov, who repeatedly noted that the main failure of our mass improvement of livestock breeding is in the poor quality and quantitative lack of feed. The scientist thoroughly studied the features of feeding Karakul sheep in the south of the Ukrainian SSR.

\footnotetext{
${ }^{11}$ Бородай І. С. Теоретико-методологічні основи становлення та розвитку вітчизняної зоотехнічної науки. Вінниця, 2012. 416 с.

${ }_{12}^{12}$ Особова справа М. П.Чирвинського // Державний архів м. Києва. Ф. 18. Спр. 284. Оп. 2. 240 арк.

${ }^{13}$ Богданов Е. А. Составление кормовых дач для молочного скота. С приложением таблиц для быстрого составления кормовых дач по наиболее простому и точному способу. Москва, 1916. 72 с.
} 
He developed the basis for fattening pigs to meat conditions for different diets and methods of keeping. He investigated the chemical composition and nutrition of local feeds, the influence of vitamins on the growth and development of farm animals ${ }^{14}$.

Thus, prerequisite for the formation and development of the science of farm animal feeding was the development of foreign and domestic scientists in the fields of physics, chemistry, physiology, biology, biochemistry and other related sciences. The greatest achievements of farm animal feeding in the pre-Soviet period are the development of systems for assessing the productive effect of feed, the justification of the impact of feeding on growth and development of animals, the experimental establishment of direct and indirect participation of feed protein in the formation of fat in the body of animals, etc.

\section{Development of Scientific Principles of Farm Animal Feeding in the Soviet Period}

We found that in the Soviet Union systematic study of problem of farm animal feeding was started in 1929, when, on the initiative by Yu. Lyskun, the theme "Study of the composition and nutrition of local feeds,"All-Union Academy of Agricultural Sciences named after Lenin established as obligatory for implementation in all branch research institutions. Since then, the efforts of specialized research institutes and universities have been directed at the development of such problems: 1) the establishment of requirements for feed rations for different species, age, sex, economic use of farm animals; 2) determination of the chemical composition of feed and development of the most economically beneficial types of feeding for different natural and climatic zones; 3) the development of mixed fodders, etc. ${ }^{15}$.

It is important to note that the complex socio-economic situation, systematic droughts and crop failure did not contribute to rational feeding of cattle. As noted by V. Ustiantsev at the first session of the Scientific Advisory Board of the People's Commissariat of Land Affairs of the Ukrainian SSR, held April 4-7, 1928, monotony and imbalance of feed caused low productivity of livestock. The main percentage of feed rations

\footnotetext{
${ }^{14}$ Бородай I. C. Теоретико-методологічні основи становлення та розвитку вітчизняної зоотехнічної науки. Вінниця, 2012. 416 с.

${ }^{15}$ Всесоюзная академия сельскохозяйственных наук им. В. И. Ленина. Ее организация, деятельность и план исследовательской работы на 1934 г. Москва, 1934. 57 с.
} 
of farm animals was roughage $(57.8 \%)$, which consisted mainly of straw [678]. The analysis of the development of the theory of farm animal feeding showed that during this period the studies focused on increasing the nutritional value of roughage on the basis of its silage, yeast, fermentation, biological and chemical processing, and others. Straw as the most economical and accessible feed steamed, quaffed, treated with quenched lime and other chemicals, enriched with minerals and microorganisms ${ }^{16}$.

In accordance with the resolution of the Council of People's Commissars of the USSR "On the work of All-Union Academy of Agricultural Sciences named after Lenin" (July 16, 1934), the primary importance was given to the use of industrial wastes in farm animal feeding. Considerable attention was also paid to increasing efficiency of use of natural and the creation of artificial pasture during fattening of cattle. To the achievements of domestic scientists in this direction we include: 1) the development of rational methods for the use of pasture and methods for assessing of herb stock by G. Chuchko; determination of the nutritional value of local meadows and pastures, justification of efficiency of the use of lupine as a feed for livestock by I. Sytenko; introduction of schemes of green conveyor for provision of cattle with feed in spring, summer and autumn by Y. Danylenko, V. Medvedev, M. Starovierov. The foundations of the flower-nectar conveyor for the practical needs of beekeeping were also developed by N. Rotmistrov and J. Savchenko. In our opinion, the greatest achievement of this period was the development of the theoretical foundations of yeast feeding as a method of its biological preparation for feeding by B. Levitskyi in 1932. Yeast fodder in comparison with usual ones was characterized by higher fodder value, protein content and vitamins, taste qualities ${ }^{17}$.

The successes in farm animal feeding of this period were largely attributed to advances in the technology of production, storage and processing of feed. Particular importance has been obtained research of silage forage. It is worth noting that the method of silage was known in Sweden and the Baltic countries as early as the 18th century, in Prussia and Germany in the 30's of the 19th century. It was used to store beet and sugar production waste, and in the 50's to preserve green fodder.

\footnotetext{
${ }^{16}$ Бородай І. С. Теоретико-методологічні основи становлення та розвитку вітчизняної зоотехнічної науки. Вінниця, 2012. 416 с.

${ }^{17}$ Левитский Б. Г. Дрожжевание кормов. Москва, 1936. 64 с.
} 
Silage became widespread in the 70's when fodder corn became widely used in France. We consider as developers of the method of silage forage the foreign scientists Lemm, Gofar. At the end of the 19th - early 20th centuries silage has spread rapidly in America, Russia, Switzerland and England ${ }^{18}$. In the Ukrainian lands, the first experiments on silage forage were conducted by K. Veresenko, I. Kalugin, F. Rubin, F. Rurikov, S. Serapin, V. Ustiantsev, they proved the effectiveness of local feed ensilage ensilage, developed technologies of combined and long-term ensilage. O. Zubrilin, a scientifically based system for preserving green fodder, developed the theory of "sugar minimum". To his achievements should also include the theoretical substantiation of the "haymaking"19.

At development of rations balanced with nutrients, minerals and biologically active substances, the idea of its replacing with mixed fodders was implemented. In the USSR the first recipes of mixed fodders at the beginning of the 20th century were proposed I. Bel'govskyi, A. Redkin, V. Smirnov, I. Shirokykh. Thus, I. Belgovskyi developed general questions of the theory and practice of production of mixed fodders, the development of the mixed fodders industry, the neutralization of some waste products for the purpose of its use in farm animal feeding. A. Redkin made a significant contribution to the development of mixed fodders for different ages and groups of pigs, their types of fattening. Most of his proposed recipes after the test were accepted as state standards and intensively used in industry ${ }^{20}$.

In prewar years the domestic scientists have studied the chemical composition, digestibility, caloric content of local feeds, established the nutritional requirements for farm animals. I. Popov initiated a study on the nutritional value assessment, and he published the book "The USSR's fodder, composition and nutrition" in 1933. M. Bogoyavlenskyi and P. Pshenychnyi in 1936 studied and developed methods of assessing the nutritional value of forages for the Forest-Steppe of the Ukrainian SSR, I. Zakharchenko and E. Kalenych for whole republic in 1948. These studies allowed to find out the change in the composition and nutrition of

\footnotetext{
${ }^{18}$ Герчиков Н. П. Силосование и его роль в системе кормодобывания сельскохозяйственных мероприятий. Вестник сельского хозяйства. 1929. № 1-2. С. 20-22.

${ }^{19}$ Зубрилин А. А. Научные основы консервирования зеленых кормов. Москва, 1947. С. 47-59. C. 23-34.

${ }^{20}$ Овсянников А. И. Пятьдесят лет советской зоотехнической науки. Животноводство. 1967. № 10.
} 
feeds under the influence of climatic conditions and agrotechnics of cultivation, methods of harvesting, preservation and storage $\mathrm{e}^{21}$.

In the 30-40s, Ukrainian scientists set requirements for feed rations of farm animals of some species, age, sex, and economic use. They studied the ability of some breeds to fatten, developed standard terms for some types of fattening. The norms and rations of cattle feeding were developed by M. Bazylevych, S. Erler, I. Zaderius, M. Starovierov and others. Priority studies on digestion of feeds, peculiarities of gastric secretion and pig nutrition, which became the theoretical basis for the development of feeding norms and rations for these species, were conducted by O. Bakieva, V. Borovskyi, O. Kvasnitskyi and etc. O. Bondarenko offered the first technology of bacon fattening pigs in the USSR.

Research on normalized feeding in livestock farming has become systematic in the first half of the $20^{\text {th }}$ century. It should be noted that scholars and specialists in feeding their rationulas used the reference "Fodder Norms and Feed Tables" (1932), prepared by I. Popov. They calculated the need for feed on the factorial principle, developed on the basis of classical studies of foreign and domestic scientists G. Armsby, E. Bogdanov, M. Dyakov, O. Kelner, K. Nering, M. Rubner et al. It provided the determination of daily standards on energy, protein, calcium and phosphorus based on the need for them to support basic metabolism, milk production, pregnancy, changes in live weight during lactation, and so on ${ }^{22}$.

We found that in the second half of the $20^{\text {th }}$ century Ukrainian scientists paid special attention to the development of problems of amino acid nutrition, protein feeding of animals, studying the possibilities of using non-protein nitrogen feed. Valuable developments in this direction were proposed by G. Bogdanov, M. Guly, O. Dmytrochenko, M. Dyakov, I. Popov, P. Pshenichny, M. Tomme and others. In particular, Ukrainian scientists have investigated the effectiveness of daily rations of ruminants which included mineral and organic salts of ammonium (sulfate, bicarbonate, acetate, lactate), urea, biuret, and others. Experiments on feeding bicarbonate of sodium with the addition of trace elements as a rich

21 Кандиба В. М. Досягнення вчених інституту тваринництва УААН в розвитку науки про повноцінну нормовану годівлю сільськогосподарських тварин і пріоритетні напрями досліджень у сучасних умовах. Науково-технічний бюлетень. Харків, 2009. Вип. 100. С. 269-277.

22 Бородай I. С. Теоретико-методологічні основи становлення та розвитку вітчизняної зоотехнічної науки. Вінниця, 2012. 416 с. 
source of $\mathrm{CO}_{2}$, used for organic synthesis in the body of animals, conducted by M. Gully.

It is worth noting that for the first post-war decades, as in the previous stage, scientific searches for additional sources of compensatory feeding of animals were characteristic. Scientists worked at the time of nearly total seizure of grain in the union fund. That is why scientists gave increased attention to scientific topics on the use of urea, phosphate shale, defecate in feeding animals. Not compatible with the satisfaction of the biological needs of animals, they sometimes caused their death. Under such conditions feeding, animals should not only survive, but also increase their productivity in accordance with the developed five-year plans.

A characteristic trend of this period is the search for new methods for assessing the overall nutrition of the feed. Thus, after the critique of bourgeois biological science at the $35^{\text {th }}$ plenum of the Animal Husbandry Section of All-Union Academy of Agricultural Sciences named after Lenin in 1951, which became a kind of continuation of the July session of the Academy in 1948, there was a refusal from the factorial and the transition to unified norms. In 1959 the manual "Fodder Norms and Tables" was edited by M. Tomme and published, in which the daily norm in feed units, the digestible protein was expressed in total, without its distribution for the maintenance of animal life, for the production of products and reproduction $^{23}$.

By the decision of March Plenum of the Animal Husbandry Section in 1963, they considered it expedient to assess the total nutrition of the feed by exchange energy. The development of a new system for assessing feed and rationing for animal feeding was carried out by P. Victorov, V. Georgievskyi, M. Denisov, M. Kleimenov, V. Kulikov, K. Solntsev, V. Fisinin, V. Shcheglov under the leadership of Academicians O. Dmytrochenko and O. Kalashnikov. In 1983, new norms were developed and approved by the Presidium of All-Union Academy of Agricultural Sciences named after Lenin, and in 1985 they were published in the manual "Norms and diets of feeding farm animals". Since then, the main indicator of energy nutrition of feeds and rations is the content of exchange energy expressed in megajoules, in the unit of natural feed and dry matter of feed or ration. By the decision of March 1963 to the plenum

\footnotetext{
23 Томмэ М. Ф. Кормление сельскохозяйственных животных. Большая Советская Энщиклопедия. 3-е изд. Москва, 1973. Т. 13. С. 530-533.
} 
of the Animal Husbandry Section, they considered it expedient to assess the total nutrition of the feed by exchange energy. The development of a new system for assessing feed and rationing for animal feeding was carried out by P.I. Victorov, V.I. Georgievsky, M.I. Denisov, M.I. Kleimenov, V.M. Kulikov, K.M. Solntsev, V.I. Fisinin, V.V. Shcheglov, for the leadership of Academicians All-Union Academy of Agricultural Sciences named after Lenin O.P. Dmytrochenko and O.P. Kalashnikov. In 1983, new norms were developed and approved by the Presidium of VASHNIL, and in 1985 they were published in the manual "Norms and diets of feeding farm animals". Since then, the main indicator of energy nutrition of feeds and rations is the content of exchange energy expressed in megajoules, in the unit of natural feed and dry matter of feed or ration ${ }^{24}$.

Thus, in the Soviet period, domestic scientists have made significant progress in the development of scientific foundations for feeding farm animals. They set the requirements for feed rations for different species, age, sex, economic use of farm animals; determined the chemical composition of forages and developed the most economically advantageous types of feeding for different natural and climatic zones; developed methods for assessing the total nutrition of feeds, etc.

\section{Development of Theoretical and Methodological Foundations for the Farm Animal Feeding of During the Period of Ukraine's Independence}

In recent decades, Ukrainian scientists have developed the basics of mineral nutrition in animal husbandry. In particular, the metabolism of phosphorus and calcium in the body, the influence of microelements on animal development was studied by G. Bogdanov. G. Klytsenko investigated the influence of salt and phosphorous feeding on cattle productivity. According to the results of many years of research, he published a monograph "Mineral Food of Agricultural Animals" (1980), in which he proposed new rules for feeding various types of farm animals of macro- and microelements, and determined its impact on productivity, growth, development and reproduction functions ${ }^{25}$.

\footnotetext{
${ }^{24}$ Томмэ М. Ф. Кормление сельскохозяйственных животных. Больщая Советская Энщиклопедия. 3е изд. Москва, 1973. Т. 13. С. 530-533.

${ }^{25}$ Клиценко Г. Т. Минеральное питание сельскохозяйственных животных. Киев: Урожай, 1980. $167 \mathrm{c}$.
} 
The influence of mineral compounds on the health and productivity of poultry was substantiated by I. Ratuch, on stimulation of the synthesis of biologically active compounds (vitamins, amino acids, antibiotics, etc.) by symbiotic microbial associations in the prehistoric ruminants by F. Palfyi. Research on the effects of quantitative changes of phosphorus compounds in the cow's rumen fluid during the feeding of essential amino acids on the metabolic processes in the pig's body and their productivity, conducted by J. Slabitskyi, have not lost its significance to our days. The scientific work of G.P. Zapadniuk and P.Z. Labodiuk was directed at the development and implementation of technologies of high-grade protein nutrition of various types of farm animals, and the study of the possibility of replenishing protein deficiency in rations of lactational cows due to the use of synthetic non-protein nitrogen compounds. The influence of lysine and methionine on the health and productivity of poultry was investigated by I. Ratych ${ }^{26}$.

M. Karpus, Yu. Savchenko and others made a significant contribution to the development of the theory of carbohydrate feeding. Thus, Yu. Savchenko found the need for sugars of different age and physiological groups of cattle, the effect of sugar content and the type of sugars on metabolism and cattle productivity. M. Karpus has developed standards for feeding different age groups of pigs of sugar feed for different levels and quality of protein, fiber and minerals.

The research on the development of the bases of vitamin nutrition of farm animals, the influence of vitamins on their health and the formation of productive qualities were conducted by I. Avramenko, G. Bogdanov, A. Zverev, I. Ionov, G. Kiseliov, S. Payenok, I. Ros, M. Sakhackyi and others. Thus S. Payrnok studied the influence of different sources of carotene and vitamin $\mathrm{A}$ on metabolic processes and meat productivity of pigs. He introduced into the production of forage forms of vitamins and developed water dispersants of fat-soluble vitamins. I. Ionov developed the theoretical bases of vitamin feeding in poultry, the principles of rationing of vitamins in rations and recipes of vitamin and mineral premixes, new methods for analyzing the content of vitamins in feed and biological material.

In our opinion, the above-mentioned works constitute the basis for the implementation of control over the full value of farm animal feeding on the

\footnotetext{
${ }^{26}$ Влізло В. В. Федорук Р. С., Ратич І. Б. та ін. Історія Інституту біології тварин (1960-2010). ЛьвівДрогобич, 2010. 324 с.
} 
basis of the study of feeds on the content of protein, minerals and carotene, as well as the state of protein, mineral and vitamin metabolism in productive farm animals.

At the end of the $20^{\text {th }}$ century, the study on normalized farm animal feeding has also been intensified. For the first time, detailed norms for farm animals feeding for the Polissya, Forest-Steppe and Steppe regions of Ukraine have been developed, according to which the dietary ratios of cattle are monitored for 20-24, pigs for 27-30 indicators. Rationing of feeding allowed to significantly increase the efficiency of nutrient use of rations and reduce feed costs per unit production by $10-15 \%{ }^{27}$. In the development of the theory of normalized feeding significant contributions were made by G. Bogdanov, V. Karavashenko, M. Karpus, M. Lapa, G. Martynyuk, M. Noszdrin, G. Provatorov, V. Slavov and others.

Ukrainian scientists established the peculiarities of rationing feeding of farm animals of various age and sex groups, of economic purpose. Thus, the system of rational feeding and keeping of bulls was developed by M. Volkoboi, E. Danilevskyi, S. Efimenko, D. Savchuk and others. The norms of consumption of carbohydrates, fats and other components in dairy cow diets were proposed by M. Knyga. Progressive technologies of intensive fattening of young cattle were introduced by R. Kavka, V. Koshelev, P. Stoliarchuk, A. Zvigun and others.

M. Kovalenko, M. Noszdrin, I. Tronchuk and other scientists developed the theory of full feeding of pigs. T. Gorb, O. Gorlov substantiated the rational system of feeding sheep for various naturalclimatic zones. The bases of complete feeding of poultry as an important factor of increasing its productivity were proposed by Yu. Batyuzhevskyi, M. Dakhnovskyi, V. Karavashenko and others. Yu. Zheltov, V. Movchan, V. Prosyany, G. Shpet performed a considerable amount of research on the development of the foundations of full feeding in fish farming ${ }^{28}$.

Ukrainian scientists conducted a series of studies on the effects of limited, variable and other types of feeding. In particular, Yu. Batyuzhevskyi for the first time in the poultry farming of Ukraine organized a multifaceted research on the limited feeding of young animals of various kinds of poultry that provides a significant saving of feed on its breeding without adversely affecting future productivity. The technology of forced

\footnotetext{
${ }^{27}$ Бородай І. С. Теоретико-методологічні основи становлення та розвитку вітчизняної зоотехнічної науки / І. С. Бородай. Вінниця, 2012. 416 с.

${ }^{28}$ Інститут рибного господарства / за ред. І. І. Грициняка. К., 2010. 352 с.
} 
fattening of waterfowl poultry was developed by E. Dyunov, I. Ivko, V. Melnyk and others.

In recent decades, new, effective recipes of feed additives, premixes and feed supplements have developed. So, L. Podobed offered compound feed and feed supplements for cattle, pigs and poultry, as well as the technology of preparation soy substitutes for milk feed for calves. Regional premixes for beef cattle, taking into account the peculiarities of the natural climatic and soil zones of Ukraine, the zoo chemical composition of feed and the type of animal feeding; contribute to lower feed costs, increase average daily increments, were developed by V. Kebko, V. Slavov, G. Shkurin and others.

The recipes of feed additives for pigs, which take into account peculiarities of metabolism and energy in farm animals, provide maximum manifestation of productivity, were developed by M. Nozdryn. Fodder with a limited content of protein of animal origin, substitutes of whole milk, as well as the technology of production of protein concentrate from juice of green plants was proposed by O. Zverev. In poultry farming physiologically substantiated norms of feeding full-fodder mixed fodders contributing to increased nutrient assimilation in the bird organism, were developed by M. Lemesheva ${ }^{29}$. The methods of improving the quality of granules of mixed fodders for growing fish in ponds, basins and gardens were grounded by Yu. Zheltov, who conducted experiments with nontraditional components suitable for fish feeding in compound fodders ${ }^{30}$.

The author has established that during this period a new direction of scientific research was substantiated namely the substantiation of the effectiveness of dietary feeding, the study of its effect on increased resistance in animals. Theoretical and methodological basis for its development is the scientific works of domestic scientists V. Alikaiev, B. Levitskyi, A. Onegov, A. Solun, I. Khrabustovskyi and others. In particular, I. Khrabustovskyi prepared "Methodological recommendations for determining the natural resistance of animals in conditions of their intensive use" (1974), in the formation of which he devoted an important role to feeding ${ }^{31}$.

In recent decades, comprehensive study have launched on the assessment of the quality of farm animal fodder. In our opinion,

\footnotetext{
${ }^{29}$ Головко В. О. Історія Харківської державної зооветеринарної академії. 155 років. Х., 2006. 500 с.

${ }^{30}$ Інститут рибного господарства / за ред. I. І. Грициняка. К., 2010. 352 с.

${ }^{31}$ Головко В. О. Історія Харківської державної зооветеринарної академії. 155 років. Х., 2006. 500 с.
} 
V.I. Gnoyevyi made important contribution on the formation of this direction, determined the quality indices of coarse and concentrated feeds in relation to its supramolecular physico-chemical and anatomical-morphological structure by zootechnical, physiological and biochemical methods. He investigated the relationship between the biomorphological structure of feed and its energy nutrition, the laws of improving the feed quality and developed methods for increasing the effectiveness of its use by ruminants ${ }^{32}$.

For further development of farm animal feeding the scientific developments by V. Kebko, O. Mamenko, Yu. Savchenko, V. Slavov, T. Shkurin, on the study of the possibility of using livestock in zones affected after the accident at the Chernobyl Nuclear Power Plant, fodder crops accumulated radionuclides are practically significant. The scientists have substantiated the effective technological methods of reducing the level of contamination of livestock products with radioactive cesium to environmentally safe norms.

Thus, the last decades are the most fruitful period of development of scientific principles of farm animal feeding. Its introduction into the practice of livestock breeding contributes to the achievement of the genetically determined level of productivity of farm animals and the necessary quality of products, ensures their health and high reproductive ability for the economical consumption of feed.

The analysis of the development of the science of farm animal feeding has shown the following directions need to study in today's extreme conditions:

1. The improvement and wide-scale introduction of stable annual system of the same type, balanced on the detailed norms of farm animal feeding with high-quality feeds from storage tanks in the farms of different zones of Ukraine.

2. The introduction into the production of domestic premixes of a new generation with increased biological and productive effects, antistress, immunostimulants, antiradionuclide qualities.

3. The development of zonal prescriptions of available proteinvitamin and mineral supplements using local vegetable protein feeds, slowly cleavable protein scavengers in synthetic sources, heat-treated legumes.

${ }^{32}$ Русько М. П. Гноєвий Віктор Іванович // Вчені у галузі тваринництва. Київ : Аграрна наука, 1999. С. 95-97. (Серія «Українські вчені-аграрії ХХ ст.»; кн. 2). 
4. The solving the problem of normalizing the amino acid nutrition of highly productive dairy and beef cattle using scarred proteins and protected indigenous amino acids.

5. The search for alternative, ecologically clean, energy, land and resource saving, using the energy of the sun, wind and biodegradable manure, a system of stable all-year-round, biologically complete, dietary feeding of animals with green fodders grown without the use of land from grain-growing crops for biohydroponic technology.

\section{CONCLUSIONS}

Thus, prerequisite for the formation and development of the science of farm animal feeding was the development of foreign and domestic scientists in the fields of physics, chemistry, physiology, biology, biochemistry and other related sciences, which formed its theoretical and methodological basis. The foundation for the establishment of farm animal feeding of in the Ukrainian lands was laid in the late $19^{\text {th }}$ century - at the beginning of the $20^{\text {th }}$ centuries. In the first half of the $20^{\text {th }}$ century domestic scientists developed the basics of assessing the nutritional value and chemical composition of local feeds, its influence on the formation of farm animal productivity was studied, the requirements for the rational composition of feed rations for animals of different species, age, gender, economic use were established. The research on mineral, amino acid, carbohydrate and vitamin feeding of cattle was initiated; the concept of balanced and normalized feeding was formed. In the second half of the $20^{\text {th }}$ century study on the effects of protein feeding, the possibility of using non-protein nitrogen feed, the growth of the biological value of protein, the role of amino acids and mineral nutrition in feeding animals was carried out. In recent decades, the study on the assessment of feed quality, the study of the effects of feeding on the formation of resistances in animals have become systematic. Detailed norms and economically profitable types of livestock feeding for various natural and climatic zones of Ukraine have been developed.

Ukrainian scientists have developed the theoretical foundations of balanced, rational feeding of farm animals which based on the determination of nutritional value of forages, the establishment of feeding standards, the development of feed rations, the optimization of equipment and organization of feeding, etc. In today's extreme 
conditions the following directions need to study: the introduction of stable annual system of the same type, balanced on the detailed norms of farm animal feeding; the production of domestic premixes of a new generation with increased biological and productive effects, the development of zonal prescriptions of available protein-vitamin and mineral supplements; the search for alternative, ecologically clean, energy, dietary feeding of animals.

\section{SUMMARY}

The aim of the research is to integrate scientific and historical analysis and to allocate periods of formation and development of farm animal feeding in the context of the world industry scientific thought. Author used the general scientific and interdisciplinary methods to solve research tasks. Particular attention paid to special historical methods, source analysis. The source base of the study includes a complex of diverse documents, the basis of which are archival materials.

The author argues that the foundation for the establishment of feeding of farm animals on Ukrainian lands was laid in the late $19^{\text {th }}$ century - at the beginning of the $20^{\text {th }}$ centuries, identifies the main periods of its development. Theoretical and methodological basis for the formation and development of the science of farm animal feeding are research of domestic and foreign scientists in the fields of physics, chemistry, physiology, biology, biochemistry and other related sciences.

It was shown that the basics of assessing the nutritional value and the chemical composition of local feeds were developed by Ukrainian scientists in the first half of the $20^{\text {th }}$ century, and its impact on the production of farm animals was studied. One of the directions of scientific development of this period was the establishment of requirements for the rational composition of feed rations for animals of different species, age, sex, economic use. Generalized research on mineral, amino acid, carbohydrate and vitamin feeding of cattle, which formed the basis of balanced nutrition. It was established that for the second half of the $20^{\text {th }}$ century. There were characteristic studies on the effects of protein feeding, the use of non-protein nitrogen feed, the growth of the biological value of protein, the role of amino acids and mineral nutrition in feeding animals. 


\section{REFERENCES}

1. Богданов Г. А. Кормление сельскохозяйственных животных. Москва, 1990. 624 с.

2. Богданов Е. А. Составление кормовых дач для молочного скота. С приложением таблиц для быстрого составления кормовых дач по наиболее простому и точному способу. Москва, 1916. 72 с.

3. Бородай I. С. Теоретико-методологічні основи становлення та розвитку вітчизняної зоотехнічної науки. Вінниця, 2012. 416 с.

4. Влізло В. В. Федорук Р. С., Ратич І. Б. та ін. Історія Інституту біології тварин (1960-2010). Львів-Дрогобич, 2010. 324 с.

5. Всесоюзная академия сельскохозяйственных наук им. В. И. Ленина. Ее организация, деятельность и план исследовательской работы на 1934 г. Москва, 1934. 57 с.

6. Герчиков Н. П. Силосование и его роль в системе кормодобывания сельскохозяйственных мероприятий. Вестник сельского хозяйства. 1929. № 1-2. С. 20-22.

7. Головко В. О. Історія Харківської державної зооветеринарної академії. 155 років. Х., 2006. 500 с.

8. Зубрилин А. А. Научные основы консервирования зеленых кормов. Москва, 1947. С. 47-59.

9. Інститут рибного господарства / за ред. І. І. Грициняка. К., 2010. 352 c.

10. Кандиба В.М.Досягнення вчених інституту тваринництва УААН в розвитку науки про повноцінну нормовану годівлю сільськогосподарських тварин і пріоритетні напрями досліджень у сучасних умовах. Науково-технічний бюлетень. Харків, 2009. Вип. 100. С. 269-277.

11. Клиценко Г. Т. Минеральное питание сельскохозяйственных животных. Киев: Урожай, 1980. 167 с.

12. Левитский Б. Г. Дрожжевание кормов. Москва, 1936. 64 с.

13. Овсянников А. И. Пятьдесят лет советской зоотехнической науки. Животноводство. 1967. № 10. С. 23-34.

14. Особова справа М. П.Чирвинського // Державний архів м. Києва. Ф. 18. Спр. 284. Оп. 2. 240 арк.

15. Особова справа П. О. Широких // Державний архів м. Києва. Ф. 18. Оп. 2. Спр. 290. 80 арк. 
16. Русько М. П. Гноєвий Віктор Іванович. // Вчені у галузі тваринництва. Київ : Аграрна наука, 1999. С. 95-97. (Серія «Українські вчені-аграрії ХX ст.»; кн. 2).

17. Томмэ М. Ф. Кормление сельскохозяйственных животных. Большая Советская Энииклопедия. 3-е изд. Москва, 1973. Т. 13. C. $530-533$.

18. Ханссон Н. Кормление сельскохозяйственных животных. Москва: Сельхозгиз, 1936. 124 с.

Information about the author: Boroday I. S., Doctor of Historical Sciences, Professor, Depute Director, National Scientific Agricultural Library of NAAS 10, Heroiv Oborony St., Kyiv, 03127, Ukraine 


\section{THE BELARUSIAN-UKRAINIAN SOCIO-CULTURAL RELATIONS IN THE SECOND HALF OF XIX ${ }^{\mathrm{TH}}$ EARLY XX ${ }^{\mathrm{TH}}$ CENTURY}

\section{Hrytsenko H. Z.}

\section{INTRODUCTION}

Mutual rapprochement of peoples at all stages of historical development depends on the intensity of their constant and diverse communication. Cultural exchange plays an important role in the spectrum of various contacts as a means of cognition of the world and spiritual development.

This period is quite important in the development of relations between two Slavic peoples, as since the $\mathrm{XIX}^{\text {th }}$ century a new concept of common language and culture has begun to emerge. In their history it was one of the most interesting and creative. It should be taken into account that the Ukrainian-Belarusian relations were established and developed in the conditions of stateless existence of the two peoples in the monarchies of the Romanovs and Habsburgs, where their lands were at different times and under different circumstances. The conditions for cultural development were also different, and this influenced the processes of national and cultural revival of Ukrainians and Belarusians. With the development of national self-consciousness in all areas of cultural interaction, there have been qualitative changes that have led to the mutual enrichment of the cultures of the two peoples. Their traditional communication has become an important part of the nation-building process.

During the periods of national revival the national idea was developed most actively. In addition, public attention was drawn to the origins of national statehood, to historical events and personalities who played this or that role in it.

In recent decades, the issues of national and cultural self-identification of Belarusians have become the most acute. The political and philosophical heritage of the Belarusian people can serve as a basis for the development of the ideological sphere of the Belarusian state, formed throughout the 
history of public thought of the Belarusian people. Public opinion is a part of the spiritual life of society, spiritual production and public consciousness, which in their content and form have a historical character ${ }^{1}$.

The exchange of universal human values has become a catalyst for national cultural growth. Through them the political tasks were also set. The introduction of broad ranges of readers, viewers and listeners to the treasure of the Slavic cultures has enabled a deeper understanding of the world around us. It can be considered that it was one of the ways of intellectual and aesthetic elevation of the Slavs.

The general Slavic thought generated by internal needs of development of separate people, has shaded the common features of their cultures and provided specifics to them. Under such conditions, UkrainianBelarusian relations in the public sphere have acquired new content.

Numerous bans by the tsarist regime of the Ukrainian printed word automatically affected the Belarusian press, as the officials of that time were afraid that with the appearance of works in the Belarusian language there was no tendency "except for the "little Russian" to create "Belarusian" literature and thus weaken the literary and national unity, and consequently the political power of the Russian people ${ }^{2}$.

Organizational registration of the Belarusian national liberation movement fell to the turning point of $\mathrm{XIX}^{\text {th }}-\mathrm{XX}^{\text {th }}$ century. By the social composition and orientation, this movement included two currents (liberal and revolutionary). This is largely due to the diversity of social sources of forming the Belarusian national intelligentsia - the basis of the ideological and organizational core of the national liberation movement. Their activities were particularly important during this period, as the ruling circles of the Russian Empire carried out a policy of consistent Russification on the Belarusian lands. Their main goal was not the welfare of the people, but the preservation of the existing political system - the guarantor of perpetuating the system of human exploitation, social and national oppression of peoples. This could not but narrow the sphere of cultural influence of Belarusian national culture on the great mass of the

\footnotetext{
${ }^{1}$ Токць С. Беларускі нацыянальны рух XIX - пачатку XX ст. у кантэксце нацыянальных рухаў народаў Цэнтральна-Усходняй Еўропы. Нацыянальныя питанні : матэрыялы III Міжнароднага кангрэса беларусістаў. Мн., 2001. С. 22.

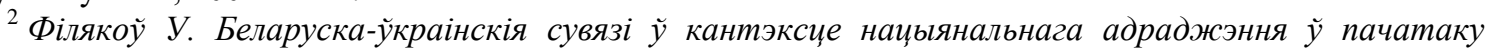
XX cm. // Беларусь-Украіна: гістарычны вопыт узаемаадносін. Мн., 2004. С. 190.
} 
population of the region. That is why the expansion of social and ethnic consciousness among the masses was slow ${ }^{3}$.

Changes in the cultural sphere, which took place in the second half of the $\mathrm{XIX}^{\mathrm{th}}$ century, contributed to the development of the national educational movement, the organizers were writers, publicists, historians, organizers of circles for the study of Belarusian-Ukrainian national problems and finding ways to overcome them. In the absence of Belarusians' statehood, independent forms of political and economic life, culture was the most important unifying factor. It ensured the preservation of ethnic identity, led to the awakening and maturation of national selfconsciousness.

\section{Belarusian National Movementin the Perception of Ukrainian Public-cultural Figures}

Ukrainian public men have always been interested in the destiny of the Belarusian people. For example, many warm words about Belarus, its people, history, culture and language were said by a prominent figure of the populist movement and a scientist of the second half of the XIX $^{\text {th }}$ century Mykhailo Drahomanov (1841-1895). One of the greatest achievements was the recognition of the equality of all peoples, including Belarusians, whose rights to independent development were defended by M. Drahomanov.

The Ukrainian Democrat did not consider the absence of the Belarusian national movement as a sign of its hibernation and passivity. Only Democrats could raise the masses of the Belarusian people to broad liberation activity. M. Drahomanov called on the ideologists of populism, who carried out extensive propaganda work in the $70 \mathrm{~s}$, to address the Belarusian people in their native language, to tell them about the causes of poverty, to point to the enemies and to raise the fight for social justice ${ }^{4} \mathrm{He}$ convinced "homans" that Belarusians can be guaranteed the equality and self-government only in the Federal building for a future state.

\footnotetext{
${ }^{3}$ Карев Д. В. Белорусская и украинская историография конца XVIII - начала 20-х гг. XX в. в процессе генезиса и развития национального исторического сознания белорусов и украинцев. Вильнюс, 2007. C. 171-172.

4 Злупко С. М. Драгоманов пра Беларусь і беларусаў. Матэрыяль першай навуковай канферэнцылі па вывучэнню беларуска-ўкраінскіх літаратурных і фальклорных сув'язей. Гомель, 1969. С. 46.

5 "Homans" were the first in Belarus, who announced the existence of the Belarusian nation. Belarusian question was openly put and theoretically justified by the populists magazine "Homan" for the first time (1884).
} 
In June 1885 in Lviv, under the influence of M. Drahomanov, the Ukrainian public figures M. Pavlyk and I. Franko made the project of activity of "Ukrainian-Polish-Lithuanian-Belarusian brotherhood" and "Publishing Union", according to which each nation had equal rights. This was the first project of the democratic program, according to which the Belarusian people were given an equal place with other neighbouring Nations. This was the main merit of M. Drahomanov, who always defended the historical rights of the Belarusian people, exposed falsifiers of history, culture and public views of the Belarusian native masses ${ }^{6}$. Scientific heritage and practical activities of M. Drahomanov testifies that Belarus and the Belarusian people had him as a sincere defender, fighter for social equality, political freedom and national independence.

An interesting page in the history of Ukrainian-Belarusian public relations is a correspondence between Voinislav Savych Zabolotskyi (1850 - after 1893) and M. Drahomanov, Lesya Ukrainka's uncle.

In letters to M. Drahomanov from the second half of the 80 -ies of the XIX $^{\text {th }}$ century written in Belarusian, V. Savych Zabolotskyi recalled some moments of his life, expressed the thought of Belarusian and Ukrainian cultures and languages, the destiny of the Slavic peoples. The writer appears in letters to M. Drahomanov as an ardent supporter of the idea of Slavic unity. As for the situation of Belarusians in the second half of the XIX ${ }^{\text {th }}$ century, he stated: "We, the primeval Rus, are now driven by God into peasantry" ". In a letter dated November 19, 1886 Belarusian figure said: "Your Ukrainian literature is very original, has a lot of interest for everyone. I have never seen such complete realism and public opinion as in

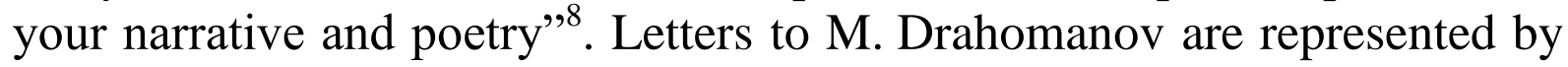
V. Savych-Zabolotskyi as a citizen and patriot concerned about the fate of his native land.

The official activity of F. Bohushevych in Ukraine was marked by civil adherence to principles, honesty, attention to ordinary people, in particular to the poor part of the peasantry. In the post-reform period, especially often, there were land conflicts between landowners and peasants. Archival documents affirm that he was a conscious defender of

\footnotetext{
6 Злупко С. М. Драгоманов пра Беларусь і беларусаў Матэрыялы периай навуковай канферэнцыьі па вывучэнню беларуска-ўкраінскіх літаратурных і фальклорных сув'язей. Гомель, 1969. С. 46-47.

${ }^{7}$ Нацыянальная бібліятэка Беларусі. Аддзел рукапісаў, старадрукаваных і рэдкіх выданняў. Ф. 178. Оп. 1. Спр. 381. Арк. 8.

${ }^{8}$ The same source. Арк. 11.
} 
the interests of Ukrainian peasants ${ }^{9}$. The struggle of F. Bohushevych against the national oppression of Belarusians by tsarism, for their national freedom was progressive, because it was a competition for democracy, native language and politic freedom of the Belarusian people.

F. Bohushevych was one of the outstanding representatives of the advanced public thought in Belarus of the last quarter of the XIX ${ }^{\text {th }}$ century. His worldview was formed under the powerful ideological influence of democratic Ukrainian culture. Most of his works hold the idea that autocracy is a heavy chain of oppression and the shackles that delay the progressive development of citizenship. The poet believed that the whole system of tsarism is lawlessness and wild wilfulness, bureaucracy, oppression and enslavement of workers. F. Bohushevych's assessment of autocracy is clearly and fully formulated in the works "The Dark Kingdom", "How to seek the truth", etc. ${ }^{10}$

In F. Bohushevych's interpretation, Belarusian nationalism is primarily a cultural nationalism based on concern "for our primeval native language" as the foundation of national culture.

Here, for example, are the words that one of the Ukrainian intellectuals, D. Doroshenko, whose house in Vilna he often visited, told about the poet: "In the spring of 1898 I got acquainted with Frantishek Bohushevych. One day, having returned from an official trip near Minsk, my father enthusiastically told me about a very interesting acquaintance... He went to Bohushevych with a visit to invite him to us... I showed the guest "The Dawn" (a journal of liberal direction, which was published in Ukrainian in Lviv); it was probably known to the guest, and he realized what the fact of getting a banned journal by a small grammar-school student in Vilna meant. He kissed my head and said that every person should love his people, respect his language and do the work of his land. These were the first words I heard in my life... from an adult, "solid" person about the national duty, and these words have forever engraved in my memory. Our guest started talking about the Belarusian people.... about the hard life of this people, about the decline of education and culture. $\mathrm{He}$ read us one poem - it was his famous "Truth"... My father and I were deeply impressed and sat in silence for several hours. Only then we

\footnotetext{
9 ДАЧО. Ф. 806. Оп. 1. Спр. 164. 29 арк.

${ }^{10}$ Лушчыцикі І. Грамадска-палітычныя і філасофскія ідэі твораў Ф. Багушэвіча. Польмля. 1955. № 8. C. 132-133.
} 
understood the beauty of the Belarusian language..."" "I hide this bright image of F. Bohushevych in my soul as one of the dearest memories: I am grateful to Bohushevych for the fact that he supported in my soul the impulse to work for the benefit of the native Ukrainian people, and since that time the fate of the Belarusian national revival has become no less expensive for me, as the fate of the Ukrainian revival"12.

Creativity and life of Aloiza Pashkevych (also known under the pseudonym Tsotka) is a vivid example of serving the people, the cause of their release from national and social oppression. The Tsotka's patriotism was based on boundless love for her Motherland and deep respect for other nationalities.

In the poem "To Neighbours in Captivity", developing Taras Shevchenko's views on the Slavic issue, she called on the Ukrainian people to fight together against social and national oppression. To Ukrainians she addressed, as to her own brothers who should lend a helping hand to Belarusians ${ }^{13}$.

The Tsotka's works, full of revolutionary pathos, could not but affect those who got acquainted with them. And these, first of all, were Lviv writers and scientists, individual employees of the "Literary and Scientific Bulletin" (LSB) and "Shevchenko Scientific Society" of that time. Founded on the occasion of the century of national revival, "LSB" promoted the idea of originality of the Ukrainian people, Ukrainian statehood, inclusion in the circle of European Nations, because, as it was noted in his program, "for our intelligent community that range of ideas, in which the cultural world lives now, the issues that interest advanced people, their competition and interests remain largely alien and unknown... The magazine will be interesting for us" ${ }^{\text {". }}$. As I. Sventsitsky remembered, Tsotka "always brought a special public pathos and direction of thought into circles in which she appeared... she performed everywhere as an ardent revolutionary against all oppression, and all untruth". The poetess "in conversations with friends uttered her national views" ". Tsotka, together with Lviv social democrats of that time brought to the minds of the workers the idea of a revolutionary renewal of life.

\footnotetext{
${ }^{11}$ Дорошенко Д. 3 Віленських вражень. Рада. 1909. № 114. С. 8-13.

12 Дарашэнка Д. Старонка з маіх успамінаў. Запісы Беларускага навуковага таварыства. Вільня, 1938. Сшыток I. С. 33.

${ }_{13}$ Арабей Л. У вигнанні. Маладосць. 1976. № 7. С. 169.

${ }^{14}$ Шаповал Ю. “Літературно-Науковий Вістник” (1898 - 1932 рр.) : Творення державницької ідеології українства. Л., 2000. С. 3.

${ }^{15}$ Свєнціцький І. Розквіт культурно-національного життя Східної Білорусі. Л., 1928. С. 21-22.
} 
Ukrainians, like Belarusians, led the revival of national consciousness in line with the mighty general democratic movement, which covered all the peoples of Russia. The pathos of appeals with which the intelligentsia appealed to the people, depended on how much the authors were really connected with the workers, personified their aspirations, revealed their vital interests ${ }^{16}$. The process of forming the Ukrainian and Belarusian nations pronounced the greatest impact only in the early twentieth century and passed at the time when international relations within the multinational Russian Empire were no less important than intra-ethnic communication.

The first Belarusian party called the Belarusian revolutionary community was founded in 1902 in St. Petersburg on the initiative and active participation of the Lutskevych Brothers (Anton and Ivan). Since the time of study in Vilna gymnasium, they were close friends of D. Doroshenko, closely associated with the Belarusian movement. A. Lutskevich wrote: "These were our two friends, who played a particularly prominent role among the student youth in general, and whose names for certain reasons are not given here: so they have left the region since 1904" $"$. He meant Dmitro Doroshenko and his friend Ivan Kraskovskyi (1880-1955), a well-known figure of the Belarusian movement.

It is interesting, that Chernihiv Belarusians gave out more illegal literature than Belarusian parties on the territory of the very Belarus ${ }^{18}$. This active publishing activity was possible thanks to the help of the Revolutionary Ukrainian party.

At the beginning of the $\mathrm{XX}^{\text {th }}$ century, with the emergence of more or less permanent political organizations, book publishing and periodicals, the Belarusian national movement really turns into a socially significant movement, that is, a progressive, continuous process ${ }^{19}$. As a result of the revolutionary events of 1905-1907, Russian tsarism made certain concessions to Belarusians: the national press, printing, the activities of cultural and educational societies were allowed.

Since the first years of their existence, close ties have been established between individual Ukrainian and Belarusian publications.

${ }^{16}$ Кабржыцкая Т. В., Рагойша В. П. Карані дружбы. Мн., 1976. С. 46.

17 Луцкевіч А. За дваццаць пяць гадоў (1903 - 1928). Мн., 1991. С. 10.

18 Ільїн О. Білоруська соціал-демократична громада Чернігівщини. Сіверянський літопис. 2012. № 1-2. C. 63 .

19 Терешкович П. В. Этническая история Беларуси ХІХ - начала ХХ в.: в контексте ЦентральноВосточной Европы. Мн., 2004. С. 181. 
On September 1, 1906 the first (official) Belarusian newspaper "Nasha dolia" ("Our destiny") appeared. No sooner had the second issue of "Nasha dolia" come out-of-print, as the Ukrainian Kyiv newspaper "Rada" (19 September) informed the readers: "On September 1st the newspaper "Nasha dolia" came out in Vilna... The direction of the newspaper is clearly indicated by the following: the first issue was confiscated by the Governor's order.... 5,000 copies were sold, 5,000 were banned by the police".

"Nasha dolia" came out in extremely difficult conditions: four of the five issued numbers were confiscated. For "calling for an armed uprising to change the state system", the court decided to "ban the publication of the newspaper "Our destiny" forever", and to put the editor of the newspaper Olexandr Vlasav (1874-1941) into prison for one year. In November, in hot pursuit of events, "Rada" prints the information about the publication of a new Belarusian newspaper. Since then, between these two newspapers a close contact has established.

Analysing the cultural life of the Belarusian people, the Kyiv newspaper "Rada" in 1907 noted that "Belarusians came to the path that will lead them into a loose, wide world between the cultural peoples, and Ukrainians, who are doing the same thing among their people, can only congratulate the educational activities of the Belarusian intelligentsia and wish success. Good luck!". Lviv edition "Ruslan" reprinted on its pages the materials of "ukrainics" from "Nasha niva" ("Our field") (Author's note: "ukrainics" is a notion which means the totality of anything that relates to history, economy, culture of Ukraine etc.). In particular, in 1910, in "Ruslan" an article "Closer to Ukrainians" appeared, which was about friendly relations of Belarusians and Ukrainians since dateless antiquity ${ }^{20}$.

Such close attention to Belarus and its people was peculiar to many publications brought out in Kyiv and Lviv. The newspapers "Ukrainska Khata" ("Ukrainian house"), "Ridnyi krai" ("Native land"), ("Dniprovi khvyli" ("Dnipro waves") actively offered the Belarusian topic to its readers.

A significant role in the cultural unity of Belarusians with the Ukrainian people was played by the materials of the daily public-political, scientific and educational literary and artistic newspaper "Nasha Niva" (1906-1915).

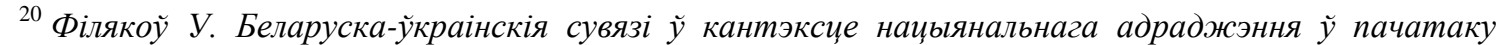
XX cm. // Беларусь-Украіна: гістарычны вопыт узаемаадносін. Мн., 2004. С. 192.
} 
From the very first issue, the weekly newspaper announced its main goal: "To all Belarusians, who do not know who they are, to understand that they are Belarusians and people, to know their right and help us in our work... And now we call on everyone who understands our ideas, feels what we hear, and wants to help us: support us in our work!"21.

"Nasha Niva" celebrated all most important events in the cultural and public life of Belarus. Thus, in the issue of November 10, 1906, it is reported that the newspaper will serve "all the Belarusian offended people" regardless of class. And two weeks later, the editors called their audience "are not the landlords and factory owners, but working people",2 . Nasha Niva" has set itself the goal to awaken the self-consciousness of Belarusians, and in this sense it has done a $\operatorname{lot}^{23}$.

The Belarusian national idea developed on the pages of "Nasha Niva" helped the intelligentsia to master the categories of the modern nation, contributed to the expansion of its social activity. The immediate result of the publication of the newspaper was that it was much more difficult for the opponents to deny the recognition of the rights to independence of the Belarusian nation, language, literature and culture ${ }^{24}$.

The main result of this cultural and educational activity is the formation of a modern understanding of the Belarusian nation.

\section{Belarusian Public About Ukrainians}

Belarusians, taking the example of Ukrainians, followed them in the same basic ways in the creation of new Belarusian literature and literary language on a national basis, in the struggle for the national printed word, in the formation of the national professional theatre, etc.

In the information sections of "Nasha Niva" often appeared Ukrainian materials, and they were selected, as a rule, from a democratic position. Local censorship let them pass only because they were not directly related to Belarus. This shows that Belarusian intellectuals were influenced by the events that took place in Ukraine. The advanced Belarusian intelligentsia in protection for an independent place of their language in the family of

\footnotetext{
${ }^{21}$ Исторические корни дружбы и единения белорусского и украинского народов. К., 1978. С. 115.

${ }^{22}$ Унучак А. "Наша Ніва" і ідейнае выхаванне беларускай інтэлігенцыі. Беларускі гістарычны yaconic. 2005. № 4. C. 20.

${ }^{23}$ Цуба М. Беларускі нацылянальны рух на пачатку ХХ ст. Беларускі гістарычны часопіс. 1996. № 1. C. 189

${ }^{24}$ Унучак А. "Нашаніўства” і “заходнерусізм”: да пытаньня ідэйнай барацьбы за беларускую інтэлігенцыю на пачатку 20 ст.. Гістарычны альманах. 2006. Т. 12. С. 118-119.
} 
other Slavic languages consolidated with progressive forces of the Ukrainian people.

"Nasha Niva", widely using Ukrainian materials, introduced the society to social life in the country in general. In every issue they gave the information on tsarist repressions, printed messages from Kyiv, Kharkiv, Odessa, Poltava and other Ukrainian cities. For example, in one of the issues of 1910 there was information that in Odessa by order of the Minister of education Kaso many students, who organized protests at the University, will be sent to the Northern provinces, several students from Kharkov will be evicted to Turukhansk region ${ }^{25}$. Often these facts were submitted without any comments. Sometimes the newspaper was looking for a suitable literary form so that the necessary information reached the understanding of the peasant-Belarusian as quickly as possible. Such messages from different places of Ukraine were published much. They forced Belarusians to take a closer look at their own lives, the same bitter and deprived of rights, called for a fight for a better life. The newspaper called on the Belarusian intelligentsia "to work sincerely for the future of their people. You have a task to arrange Belarusian reading circles, to organize parties, to invite peasant youth to them, to teach them good, to show all the beauty of their native land"26.

S. Poluian, who at that time was receiving higher education in Ukraine, joined the Ukrainian movement, thanks to the University student Joseph Hermaize, around whom the patriotic students Victor Romanovskyi, Mykola Zerov, Petro Horetskyi, etc were grouped. In particular M. Zerov is a well-known Ukrainian poet and linguist, V. Romanovsky, J. Hermaize are Ukrainian historians, students of the Belarusian historian M. Dovnar-Zapolskyi. V. Romanovskyi was born in Hlukhiv. That might be because of him that S. Poluian maintained contacts with Y. Zhurba and Hlukhivskyi circle ${ }^{27}$. In their "Letters from Ukraine" they constantly informed Belarusians about the socio-political and cultural life, the interest of Ukrainians in Belarusian literature and tried to influence the formation of public opinion.

"Letters from Ukraine" full of rich factual material, filled with the spirit of warm attitude to Ukraine and its people, a sense of gratitude for

\footnotetext{
${ }^{25}$ Аб беларускім національным адрадзэньні. Наша ніва. 1910. № 46. С. 668.

${ }^{26}$ Пятрок 3 Вярхоўя. Да нашых беларускіх інтэлегентоў. Нама ніва. 1914. № 1. С. 3.

27 Ільін А., Гарбачык М. Нацыянальнае адраджэньне пачатку XX ст. : беларуска-ўкраінскія повязі.Спадчына. 2000. № 2. С. 42.
} 
understanding and help. The first of the "letters" about "The unity between Belarusians and Ukrainians" was, in fact, a brief historical overview of Ukrainian-Belarusian unity from the XIV century and until the beginning of $X^{\text {th }}$ century. The poet Y. Zhurba noted that Belarusians and Ukrainians have much in common in the national affair of two peoples. The only difference is that the Ukrainian national affair is much ahead of the Belarusian one. The Belarusian intelligentsia aspired to eliminate this difference. An example for them for some time was the work of Ukrainians on the development of their culture and literature and national affair, "from whom we have a lot to learn". Y. Zhurba finished his letter with the words of M. Hrushevskyi: "In close friendship, in the community of ideas of freedom and progress, let the strength of these peoples increase. After different woes and losses let their ancient eagle youth be reborn, and cover with its the wings the desperate people, suppressed by poverty!"28.

Living in Ukraine, the writer could directly cooperate with the figures of the Ukrainian literary movement. Everything important that he noticed in the public life of the Ukrainian people, right there popularized among Belarusians. Largely thanks to Y. Zhurba Belarusians are familiar with the fact, what happened in Ukraine in the early $\mathrm{XX}^{\text {th }}$ century.

Having a broad understanding of the problems of the national liberation movement, S. Poluian has never been a supporter of the narrow national struggle, limiting work only to his own, specifically Belarusian national interests. For him, the national cause was international. He was a supporter of all the oppressed peoples, all his thoughts and aspirations were directed at them. In 1909 S. Poluian noted that at that time it was difficult to exist without sincere supporters between other nations. And for this purpose it is necessary for each people to get acquainted with the life and position of the national affairs of others. In the same letter, the researcher said that the magazine "Ukrainska Khata" established the Belarusian section for Belarusian authors on its pages ${ }^{29}$. S. Poluian in his messages from Ukraine appealed to the Belarusian and Ukrainian youth to join forces to help the people get out of the darkness, get light and a happy future.

At the same time, while living in Kyiv, S. Poluian studied the development of the national Ukrainian literature and the press, trying to

\footnotetext{
28 Журба Я. Аб еднасьці меж біларусамі і украінцамі. Наша ніва. 1909. № 13-14. С. 202.

${ }^{29}$ Палуян С. Лісты у будучыню. Мн., 1986. С. 101-102.
} 
influence the formation of public opinion. The letter from Ukraine (VI) describes the atmosphere of mutual respect, understanding and support that existed between the advanced Ukrainian and Belarusian youth. Thus, in 1909, professor of Kharkiv university O. Pohodin organized for a group of students a trip along Russia and Austria-Hungary to acquaint them with the life and culture of different Slavic peoples. In Kyiv, the progressive Ukrainian public organized an evening of friendship between Belarusians and Ukrainians in the Ukrainian club, where the composer M. Lysenko performed. He was the person, who stressed that these first steps to the rapprochement of peoples and knowledge of each other are of great cultural importance. In all the speeches, including professor O. Pohodin, Belarusian critic O. Bulba, the key concept was the idea of the living force of the revival of the people, that it was the time for the peoples, forgetting their grievances of national pressure, reconciled ${ }^{30}$.

Progressive Ukrainian intelligentsia has done a lot to convey the printed word to the labour masses, who were deprived, in fact, of education, light and vision. Recalling the works of Ukrainians, Belarusian writers and journalists urged the countrymen to follow the example of their good initiatives. So, Belarusians learned that 14 new libraries, 20 separate "zemstvo" bookstores were opened in Poltava "zemstvo", that Kharkiv workers built a house at their own expenses (114 thousand rubles), which housed a theatre, a library, a crafts workshop and primary school. (Author's note: "zemstvo" was the local government, very limited in the rights, established in pre-revolutionary Russia and Ukraine according to the Zemstvo reform in 1864). Other information related to Ukrainian "Prosvita", which has 140 thousand members, has 74 departments in different places, 2468 people's reading rooms etc. In particular, in 1887 the Society acquired 50 books of Belarusian editions "O Skorine" and "Molytvenik dlia detei" ("Prayer for children"), 10 books "Hungarian Rus"31.

The Belarusian Newspapers quite often provided information about various Ukrainian publications. In particular, that Kyiv has 7 Ukrainian magazines, including 1 daily newspaper "Rada", 2 weekly ones "Slovo" ("Word") and "Ridnyi krai" ("Native land"), 2 monthly literary and public magazines "Literaturno-Naukovyi Visnyk" ("Literary and Scientific Bulletin") and "Ukrainska Khata" ("Ukrainian house"), which was less

\footnotetext{
${ }^{30}$ Журба Я. Лісты з Украйны VII. Наша ніва. 1909. № 16. С. 229-230.

31 Выказь руху книжок, котрі Товариство закупило або даром достало. Просвіта 1886. Л. : Зь друкарнь Товариство ім. Шевченка, 1887. С. 15-16.
} 
accessible to everyone ${ }^{32}$. This was done in order to show Belarusians that the neighbours, who were depressed no less, than them, but the cause of their spiritual revival was much better.

In one of the issues of 1909 "Nasha Niva" placed photos on the entire newspaper page. It gave readers the opportunity to see all of the Ukrainian literary journals published throughout 1905 - 1909. The photo, placed in the newspaper, served as a kind of index of addresses, where you could easily find the best samples of Ukrainian writing. So, it pointed to individual works of I. Franko, Lesia Ukrainka, M. Kotsiubynskyi, A. Krymskyi, V. Stefanyk, who took the main places in the "Literary and Scientific Bulletin". "Nasha Niva" also directed the reader to the newspaper "Ukrainska dumka" ("Ukrainian thought"), one of the most active employees of which was B. Hrinchenko. "Ukrainian thought" aroused wide interest in the Ukrainian printed word, was one of the first weekly newspapers, which quite fully reflected the revolutionary rise in Russia and Ukraine, the struggle of workers against social and national oppression. "Nasha Niva" drew attention to the magazine "Ukraine" 33 , in which during 1907 important problems of social and cultural life, various scientific issues were raised, and fundamental works on the development of the Ukrainian language and literature were published.

"Nasha Niva" suggests the Belarusian literary and scientific forces to use the call of one of the Kyiv magazines and to start cooperating with the Ukrainian editions. S. Poluian with a feeling of boundless gratitude to Ukrainians for their support claims that such a step should be of great benefit to both peoples ${ }^{34}$. In particular, Ukrainians will have the opportunity not only to receive news from Belarusian life, but also get acquainted with the aspirations and needs of the Belarusian people.

"Nasha Niva" highlights the thoughts and hopes of Belarusians for a better fate, the fact that Belarus will be at the very stage of development, which the neighbouring countries stepped up, to which Ukrainians, Czechs, Poles and other peoples have risen ${ }^{35}$. In order for Belarusians to become a strong nation, to be able to win universal human rights, Y. Zhurba noted two conditions: "We need to give as much light to Belarusians as possible, because darkness is the main reason for our plight; and also we have to

\footnotetext{
32 Журба Я. Лісты з Украйны VII. Наша ніва. 1909. № 16. С. 229.

33 До чытачоў. Наша ніва. 1910. № 27. С. 401-403.

34 Журба Я. Лісты з Украйны VIII. Наша ніва. 1909. № 33. С. 480.

${ }^{35}$ The same source.
} 
raise the national consciousness of Belarusians, to wake their sleepy minds, so that they were not as darkened as before, so that the difficult living conditions changed for the better. Only then the dead Belarus will start life again, having been reborn anew"36.

Since that time, the ties with each month have intensified and spread, Ukrainians also began to show interest in the national Belarusian Revival. February 23, 1909 the library of Shevchenko Scientific Society in Lviv asked the editors of "Nasha Niva" to send the newspaper files for 1908-1909. Later, on 3 April 1909, Lviv newspaper of the national direction named "Dilo" ("Business") asked the editors of "Nasha Niva" to share the subscription to 1909. On 25 April 1909, V. Burachenko, the bookseller of "Prosvita" publisher in Odessa, asked to send him the newspaper and books the publishing "Nasha Niva". Just before Christmas of 1909, a letter with a similar request was received by the editorial office of "Nasha Niva" from the Kharkiv public library".

"Nasha Niva" was trying to promote only the best, progressive that was in the activities of the Ukrainian association "Prosvita". After all, the activities of the public cultural and educational society "Prosvita" in Halychyna, founded by the best representatives of the Ukrainian intelligentsia in 1868, was one of the most significant phenomena of the national history in the second half of the XIX ${ }^{\text {th }}$ - first half of the $\mathrm{XX}^{\text {th }}$ century. The society contributed to the spread of the best achievements of the Ukrainian and world culture, initiated various events, celebrations that were of national importance. This is, in particular, the annual celebration of the day since the death of T. Shevchenko, which was of great importance for the formation of the national consciousness of Halychany (Halychyna inhabitants). His name was deeply revered by the fighters for noble, high ideas in many national literatures, including the young Belarusian writing.

Thus, the reader through "Nasha Niva" formed a certain image of Ukrainians as a people who gradually woke up to national consciousness, although before it was the same as Belarusians, and the Ukrainian language, which was previously considered a peasant one, has already sounded in University classrooms. The authors of the newspaper forced Belarusians to look closely at their own lives, called for a fight for a better

\footnotetext{
${ }^{36}$ Цішка Гартны. Думкі бела руса. Наша ніва. 1909. № 33. С. 481.

37 Журба Я. Беларуская нацыянальная хэўра. Наша ніва. 1908. № 7. С. 4.
} 
life. "...We know that the people's Belarusian weekly newspaper "Nasha Niva" now produces a great mission - the awakening of the national consciousness of Belarusians and has a success. ... for the Revival is a struggle for the freedom of creativity, for the freedom to identify themselves in life". Such thoughts brings brochure by A. Novyna (A. Lutskevych), giving a variety of information about the cultural revival of Belarusians ${ }^{38}$. The result of the cultural and educational work of the Belarusian democratic intelligentsia in national and cultural Revival was the awareness of the population of Belarus and the educated part of Russian society of the fact, that the Belarusian people are not the "cattle", but an independent national value, a living cultural and social force" 39 .

Therefore, for "Nasha Niva" the Ukrainian theme was one of the most appropriate and winning. It thereby revealed the beauty and poetry of the native language to the readers, asserted its equality among other languages, and at the same time contributed to the strengthening of friendship between the Ukrainian and Belarusian peoples.

The whole range of cultural life of Belarus and Ukraine of the specified period testified that a steady interest in the language, history, ethnography, folklore of the Belarusian and Ukrainian peoples is born among the intelligentsia, the foundation of written literature in the Ukrainian and Belarusian languages is formed. All these are undoubted signs of ageing of a new stage of ethnic self-consciousness of Ukrainians and Belarusians - national identity. New forms of cultural life of the Ukrainian and Belarusian peoples also testified to the rapid development of their national culture. The participation of the general population in the activities of cultural and educational societies has intensified the growth of national consciousness and creative initiative of the two peoples.

\section{CONCLUSIONS}

The presence of Ukrainian and Belarusian ethnic lands in the Russian and Austro-Hungarian monarchies influenced not only their socioeconomic, but also cultural and educational development, the nature of relations. The impact was different (through public policy, through personal relationships, etc.) and not the same. It was widely and

\footnotetext{
${ }^{38}$ Шаповал М. Антонь Новина. Билоруссы. Украӥнська хата. 1909. № 1. С. 560.

${ }^{39}$ Нордберг М., Кузио Т. Построение наций и государств. Историческое наследие и национальное самосознание в Белоруссии и Украине (сравнительный анализ) // Белоруссия и Россия: общества и государства. М., 1998. С. 132.
} 
comprehensively manifested in the sphere of culture, primarily in education, science and social life.

It was through culture that the Slavs declared themselves as original peoples. Of course, this reflected on the content and forms of their relationship, increased interest in the history and culture of their neighbours. Language affinities, common tasks of social and political development were the basis of their unity. The search for ways and forms of their rapprochement and cooperation led to the emergence of concepts of Slavic community and programs of the Slavs unity. During this period, some Ukrainian socio-cultural figures tried to support Belarusians in their struggle for their national identity. Educated officials, many of whom showed themselves as writers, scientists, teachers and other workers in the field of culture, maintained lively contacts with their colleagues in various territories of the Empire. Their relationship contributed not only to scientific researches, but also to the mutual influence and enrichment with progressive ideas, and was the impetus for the development of drastic actions.

The attitude to the national issue in Belarus and Ukraine took an important place in bilateral relations. Drastic manifestations took place mainly in the field of journalism and distribution of brochures of revolutionary content. The events of 1863 , the activities of the organization of Belarusian populists "Homan", the appearance of the program "Ukrainian-Polish-Lithuanian-Belarusian brotherhood" and "Publishing Union" of M. Pavlyk and I. Franko, journalism of M. Drahomanov and S. Podolynskyi, revolutionary-agitation activity of A. Hurynovych were vivid evidence of this. Under the national oppression of tsarism, the scientific and educational activities of Belarusians remained a private affair of many Belarusian public and political associations. It had a close connection with the national liberation movement, acquired the character of self-defence against Russification and Polonization.

It seems obvious that on the verge of $\mathrm{XIX}^{\text {th }}$ - beginning of $\mathrm{XX}^{\text {th }}$ century the Ukrainian movement largely served as the model of the Belarusian national movement. However, there is no doubt that, despite all the troubles, the formation of the Belarusian nation and the emergence of an independent Belarus is a historically objective and inevitable process. 


\section{SUMMARY}

The article shows the importance of the idea of Slavic reciprocity in its various manifestations in the development of cultural and social contacts. It is emphasized that the formation of the Belarusian national idea was the basis of the national-state self-consciousness of Belarusians. The support of Ukrainians in the struggle of Belarusians for their national identity, Ukrainian influence on the processes of national and cultural revival of Belarus and the participation of Belarusian leaders in the Ukrainian social and cultural life is highlighted.

Ukrainian materials of the newspaper "Nasha Niva" show that Belarusian intellectuals were influenced by the events that took place in Ukraine. It affirmed the equality of the Belarusian language among the Slavic languages, and at the same time contributed to the strengthening of friendship between the Ukrainian and Belarusian peoples.

Through the prism of relations a number of components of the problem of national revival of the two Slavic peoples in the second half of the $\mathrm{XIX}^{\text {th }}-$ early $\mathrm{XX}^{\text {th }}$ century was revealed.

\section{REFERENCES}

1. Аб беларускім національным адрадзэньні. Наша ніва. 1910. № 46. С. 668 .

2. Арабей Л. У вигнанні. Маладосц̧ь (Мінск). 1976. № 7. C. $168-172$.

3. Выказь руху книжок, котрі Товариство закупило або даром достало. Просвіта 1886. Л. : Зь друкарнь Товариство ім. Шевченка, 1887. C. $15-16$.

4. Дарашэнка Д. Старонка з маіх успамінаў. Запісы Беларускага навуковага таварыства. Вільня, 1938. Сшыток I. С. 30-33.

5. Державний архів Чернігівської області (ДАЧО). Ф. 806. Оп. 1. Спр. 164. 29 арк.

6. До чытачоў. Наша ніва. 1910. № 27. С. 401-403.

7. Дорошенко Д. 3 Віленських вражень. Рада.-1909. № 114. C. 8-13.

8. Журба Я. Аб еднасьці меж біларусамі і украінцамі. Наша ніва. 1909. № 13-14. С. 200-203.

9. Журба Я. Беларуская нацыянальная хэўра. Нама ніва. 1908. № 7. C. 3-4.

10. Журба Я. Лісты з Украйны VII. Наша ніва. 1909. № 16. C. 229-230. 

C. 480 .

11. Журба Я. Лісты з Украйны VIII. Наша ніва. 1909. № 33.

12. Злупко С. М. Драгоманов пра Беларусь і беларусаў. Матэрыялы першай навуковай канферэнцыі па вывучэнню беларускаўкраінскіх літаратурных і фальклорных сув'язей. Гомель : Знание, 1969. C. 45-49.

13. Исторические корни дружбы и единения белорусского и украинского народов / под ред. Кондуфор Ю. Ю. К. : Научная мысль, 1978. $235 \mathrm{c}$.

14. Ільін А., Гарбачык М. Нацыянальнае адраджэньне пачатку ХХ ст. : беларуска-ўкраінскія повязі. Спадчьıна. 2000. № 2. С. 37-57.

15. Ільїн О. Білоруська соціал-демократична громада Чернігівщини. Сіверянський літопис. 2012. № 1-2. С. 61-63.

16. Кабржыцкая Т. В., Рагойша В. П. Карані дружбы. Беларускаукраінскія літаратурныя узаемасувязі пачатку XX ст. Мн. : Навука і тэхніка, 1976. $125 \mathrm{c}$.

17. Карев Д. В. Белорусская и украинская историография конца XVIII - начала 20-х гг. XX в. в процессе генезиса и развития национального исторического сознания белорусов и украинцев. Вильнюс : ЕГУ, 2007. 312 с.

18. Луцкевіч А. За дваццаць пяць гадоў (1903-1928). Мн. : Юнацтва, 1991. 65 с.

19. Лушчыцкі І. Грамадска-палітычныя і філасофскія ідэі твораў Ф. Багушэвіча. Полымя. 1955. № 8. С. 130-142.

20. Нацыянальная бібліятэка Беларусі. Аддзел рукапісаў, старадрукаваных і рэдкіх выданняў. Ф. 178. Оп. 1. Спр. 381. Арк. 8.

21. Нордберг М., Кузио Т. Построение наций и государств. Историческое наследие и национальное самосознание в Белоруссии и Украине (сравнительный анализ). Белоруссия и Россия: общества и государства. М. : Просвещение, 1998. 196 с.

22. Палуян С. Лісты ў будучыню. Мн. : Мастац. літ., 1986. 214 с.

23. Пятрок з Вярхоўя. Да нашых беларускіх інтэлегентоў. Наша ніва. 1914. № 1. С. 3 .

24. Свєнціцький I. Розквіт культурно-національного життя Східної Білорусі. Л. : Наклад автора, 1928. 41 с.

25. Терешкович П. В. Этническая история Беларуси XIX - начала XX в.: в контексте Центрально-Восточной Европы. Мн. : БГУ, 2004. 223 c. 
26. Токць С. Беларускі нацыянальны рух XIX - пачатку XX ст. у кантэксце нацыянальных рухаў народаў Цэнтральна-Усходняй Еўропы. Нацыянальныл питанні : матэрыялы III Міжнароднага кангрэса беларусістаў. Мн. : БГУ, 2001. 125 с.

27. Унучак А. "Наша ніва" i ідейнае выхаванне беларускай інтэлігенцыі. Беларускі гістарычны часопіс. 2005. № 4. С. 16-21.

28. Унучак А. "Нашаніўства" і “заходнерусізм": да пытаньня ідэйнай барацьбы за беларускую інтэлігенцыю на пачатку 20 ст. Гістарычны альманах. 2006. Т. 12. С. 108-122.

29. Унучак А. Сувязь “Нашай нівы” з украінскім нацыянальным адраджэннем (пачатак XX ст.) // Беларусь-Украіна: гістарычны вопыт узаемаадносін. Мн. : Ін-т гісторыі, 2004. С. 187-190.

30. Філякоў У. Беларуска-ўкраінскія сувязі ў кантэксце нацыянальнага адраджэння ў пачатаку XX ст. // Беларусь-Украіна: гістарычны вопыт узаемаадносін. Мн. : Ін-т гісторыі, 2004. C. 190-194.

31. Церашковіч П. Сацыяльныя перадумовы фарміравання ўкраінскай і беларускай нацыянальных супольнасцей у XIX - пачатку XX ст. // Беларусь-Украіна: гістарычны вопыт узаемаадносін. Мн. : Ін-т гісторыі, 2004. С. 182-186.

32. Цішка Гартны. Думкі бела руса. Нама ніва. 1909. № 33. C. 479-481.

33. Цуба М. Беларускі нацыянальны рух на пачатку XX ст.. Беларускі гістарычны часопіс. 1996. № 1. С. 182-191.

34. Шаповал М. Антонь Новина. Билоруссы. Украӥнська хата. 1909. № 1. C. 560.

35. Шаповал Ю. “Літературно-Науковий Вістник” (1898-1932рр.) : Творення державницької ідеології українства. Л., 2000. 352 с.

\section{Information about the author:}

\section{Hrytsenko H. Z.,}

Candidate of Historical Sciences,

Senior Lecturer of the Department of World History and Special Historical Disciplines,

Drohobych Ivan Franko State Pedagogical University 46, Lesya Ukrainka St., Drohobych, Ukraine 


\section{PECULIARITIES OF SCIENTIFIC SCHOOLS'ACTIVITY DIRECTIONS TO IMPROVE AGROECOSYSTEMS IN FOREST-STEPPE OF UKRAINE (SECOND HALF OF THE XIXth - BEGINNING OF THE XXIst CENTURIES)}

Kovalenko N. P.

\section{INTRODUCTION}

At the beginning of the $\mathrm{XXI}^{\mathrm{st}}$ century, the development of agricultural sector of Ukraine was ensured by the introduction of effective agroecosystems based on the use of scientifically grounded structure of the cultivated areas and specialized crop rotations with efficient alternation of different biological crop groups, rational fertilization and cultivation systems application, as well as environmentally safe measures ${ }^{1}$. Their introduction solved important practical tasks in two directions: soil fertility reproduction and natural environment preservation, as well as providing high-quality food for the population of Ukraine ${ }^{2}$.

Improvement of agroecosystems in different soil climatic conditions of Ukraine was based on the accumulation and synthesis of scientific knowledge provided by favorable conditions for scholars' scientific creativity capable of expanding effective search activity ${ }^{3}$. It became important to find out the preconditions for creation, regularities and activity specifics of the scientific teams of researchers, for systematizing their scientific developments to improve agroecosystems for different soil and climatic conditions of Ukraine ${ }^{4}$. The scientific school was regarded as an informal creative community of different generations of highly qualified scholars led by a scientific leader within a certain research direction ${ }^{5}$. They

\footnotetext{
${ }^{1}$ Бойко П. І., Блащук М. І., Демиденко О. В. Сівозміни та родючість чорнозему Лівобережного Лісостепу : монографія. Сміла, 2019. 450 с.

${ }^{2}$ Бойко П. І. Біологічна та екологічна роль сівозмін у землеробстві. Київ: Знання, 1990. 48 с.

Коваленко Н. П. Становлення та розвиток науково-організаційних основ застосування вітчизняних сівозмін у системах землеробства (друга половина XIX - початок XXI ст.) : монографія. Київ: ТОВ «Нілан-ЛТД», 2014. 490 с.

${ }^{4}$ Юркевич Є. О., Коваленко Н. П., Бакума А. В. Агробіологічні основи сівозмін Степу України: монографія. Одеса: Одеське видавництво «ВМВ», 2011. 240 с.

${ }^{5}$ Онопрієнко В. І., Ткаченко В. М. Історія української науки. Київ, 2010. 652 с.
} 
were united by common approaches to problems solving, work style and thinking, the originality of ideas and methods of implementing scientific programs. They have obtained important results; have authority and public recognition in certain fields ${ }^{6}$.

The integrity of the scientific school was ensured by the organic integration of individual scientists' and generations' scientific research, united by the general program and style of research work. Structuring and hierarchy, which was conditioned by the subordination and features of the internal structure of the scientific school formed under the leadership of a scientist-leader. Multifunctionality, which consisted in the implementation of educational, informative, research, social and cultural, and other functions. Mandatory criteria of the scientific school was the ability to independently maintain or improve the level of their organization when changing the internal or external conditions of existence, to function to increase the stability, integrity. Purposefulness, provided by the activity subordination to clearly defined research program, the continuous development of certain scientific directions by several generations of scientists ${ }^{7}$. Effectiveness was significant, which was determined by the level of scientific production received; the ability to popularize the scientific school scholars' achievements: publications, seminars, conferences, etc.

The preconditions for the scientific schools formation to improve agroecosystems were the theoretical knowledge accumulation and organizing, the availability of a full research program for the future, which was possible only with the organization of sectoral institutions network. The main centers of their creation were the departments of higher educational institutions and laboratories of research institutes, which played the role of the leading units of fundamental and applied branch knowledge accumulation, multiplication and spreading. In the second half of the $\mathrm{XIX}^{\text {th }}$ and early $\mathrm{XX}^{\text {th }}$ centuries, a great number of branch scientific schools were established, analyzing the activity directions for agroecosystems improvement in different soil and climatic conditions of the Forest-Steppe region of Ukraine provided the use of the most significant achievements of the past for long-term development of agrarian science and practice based on regional peculiarities.

\footnotetext{
${ }^{6}$ Микулинский С. Р., Ярошевский М. Г. Школы в науке. Москва: Наука, 1977. 523 с.

${ }^{7}$ Храмов Ю. А. История формирования и развития физических школ на Украине. Киев: Феникс, 1991. 216 c.
} 


\section{Contribution of Scientific Schools Researchers for Agroecosystems of Grain Direction Development}

A well-known scientific school for agroecosystems of grain direction development in the Right-Bank Forest-Steppe of Ukraine was founded in 1868 in the Uman Agricultural and Horticulture College (now Uman National Horticulture University). Even at the beginning of its foundation by Professor A. S. Husakivskii, efficient technologies of crops growing in crop rotations of the Right-Bank Forest-Steppe of Ukraine were developed $^{8}$. In 1912 theoretical and methodological aspects of efficient crop growing technologies in crop rotations were developed by Professor M. K. Vasiliev, who published a textbook «Private agriculture or field and meadow crops doctrine», which for a long time was a major for agricultural educational institutions.

Professor S. S. Rubin was the follower of this scientific school and he identified the best grain crops precursors, timely periods of soil cultivation and fertilizers application in crop rotations in the conditions of the Right-Bank Forest-Steppe of Ukraine. His students Professors V.P. Hordienko, V. O. Yeshchenko substantiated theoretical and methodological bases for the application of surface soil cultivation under grain crops ${ }^{9}$. In the second half of the $\mathrm{XX}^{\text {th }}$ century, the scientific school received recognition through the development and implementation of: effective grain crop rotation by P. M. Fedchenko; covering crops for longterm bean grasses in forage crop rotations by H. D. Derkach, O. I. Zinchenko; multifaceted crop rotation with different steam types and a wide range of winter wheat precursors by A. F. Dichtiar, S. S. Rubin. Scientists have identified effective directions for agroecosystems development: I. M. Karasiuk - fertilizer systems in grain crop rotations; O. I. O'lkhovska - precursors in field crop rotations; O. M. Lipinskii farmland crop rotations with different saturation of intermediate crops by; V. S. Pidvysotskii - precursors in seed crop rotations ${ }^{10}$.

Researches of the scientific school paid much attention to the establishment of theoretical and methodological foundations for the optimization of agroecosystems: perennial grasses - annual grasses

8 Коваленко Н. П. Становлення та розвиток науково-організаційних основ застосування вітчизняних сівозмін у системах землеробства (друга половина XIX - початок XXI ст.) : монографія. Київ: ТОВ «Нілан-ЛТД», 2014. 490 с.

9 Карасюк І. М., Замаховська М. Ю. Уманська сільськогосподарська академія (1884-1999). Київ: Сільгоспосвіта, 1999. 47 с.

${ }^{10}$ Бойко П., Данилевский А. Координационное совещание. Земледелие. 1973. № 10. С. 79. 
rotation by O. P. Danylevskyi, S. S. Rubin; effective precursors for strong varieties of winter wheat with fertilization by O. B. Karnaukh, Yu. F. Tereshchenko; agroecological assessment of crop rotation by V. O. Yeshchenko, V. P. Oprysko; specialized crop rotations with grain crops and sugar beet growing by V.P. Hordienko ${ }^{11}$. At the beginning of the $\mathrm{XXI}^{\text {st }}$ century, the nearest hear of S. S. Rubin's scientific traditions Professor V. O. Yeshchenko for the first time comprehensively described the effective field crop rotations of various economic directions in agroeconomic terms. His students made a significant contribution to the development of effective agroecosystems: V. P. Opryshko has developed crop rotations with optimum saturation of grain crops; S. P. Koval', A. V. Novak have worked out a wide range of effective precursors for oilseeds and rapeseed; M. V. Kaliievskii has determined the rational basic tillage of soil under oilseed flax; S. V. Usik has scientifically grounded crops alternation in crop rotations with short-term rotation.

Scientists have published more than 100 scientific works. The most important are the following: S. S. Rubin's monographs «Crop Rotation» (1962) and «So that the soil was fertile» (1969); V. O. Yeshchenko's, P. H. Kopytko's, V. P. Opryshko's monograph «Crop Rotation of the Forest-Steppe Zone» (2007). Of great importance were textbooks and tutorials: «General Agriculture» (1964), «Agriculture» (1980) by S. S. Rubin; «General Agriculture» (2004) V. O. Yeshchenko; «Crop rotations in agriculture of Ukraine» (2008) by I. D. Primak, V.O. Yeshchenko, Yu. P. Man'ko and numerous methodological guidelines for the practical implementation of crop rotation of various types $^{12}$. Over 80 Candidates and Doctors of Sciences have been trained by the scientific school. At the beginning of the $\mathrm{XXI}^{\text {st }}$ century, researches of the scientific school continued their activity, solving the following tasks: agroecological substantiation of short-term crop rotations with high grain crops saturation; development of minimization of the basic soil cultivation under grains and row crops; agroecological substantiation of weed control measures in crop rotations of the Right- Bank Forest-Steppe of Ukraine.

11 Коваленко Н. П. Становлення та розвиток науково-організаційних основ застосування вітчизняних сівозмін у системах землеробства (друга половина XIX - початок XXI ст.) : монографія. Київ: ТОВ «Нілан-ЛТД», 2014. 490 с.

12 Коваленко Н. П. Становлення та розвиток науково-організаційних основ застосування вітчизняних сівозмін у системах землеробства (друга половина XIX - початок XXI ст.) : монографія. Київ: ТОВ «Нілан-ЛТД», 2014. 490 с. 
Scientific school for the development of grains agroecosystems in the Forest-Steppe of Ukraine deserves attention. It is well-known in Ukraine and abroad. It was founded in the Central Agrochemical Laboratory (now NSC «Institute of Agriculture of NAAS») in 1898. From the beginning of its creation under the guidance of Academician O. I. Dushechkin systematic studies on the effective introduction of mineral fertilizers have been initiated, namely: superphosphate, nitrate, tomaschek; chemical reclamation: liming of acid and gypsum of salt-soaked soils; effective saturation of crop rotation with grain crops $^{13}$. At the beginning of the $\mathrm{XX}^{\text {th }}$ century, the extension of systematic research to improve lime and other agrochemical measures application in crop rotation of the ForestSteppe of Ukraine was continued by the closest O. I. Dushechkin's student, Candidate of Sciences F. A. Popov. He has published more than 110 scientific works. His monograph «On insolvency of grasslands in the scientific foundations of agriculture system» (1961) is the most significant. Professor O. M. Nadezhdin has developed effective grain crop rotation; candidate of science I. L. Kolosha has substantiated effective fertilizer systems; H. H. Makhov has introduced soil protective crop rotation for erosional hazardous soils.

In the second half of the $\mathrm{XX}^{\text {th }}$ century, the scientific school received recognition due to the Candidate of Sciences V. O. Pastushenko's new approaches definition to the theoretical and methodological foundations of crop rotation of various types, saturated $40-100 \%$ by grain crops, $10-40 \%$ by industrial crops, $10-60 \%$ by forage and intermediate crops for various specialization of agricultural production ${ }^{14}$. Researches of the scientific school P. I. Boiko, I. H. Zakharchenko, V. V. Kul'bida, H. K. Medvid', I. H. Predko firstly established scientific and methodological principles of agricultural crops placement in grain and row crop rotations for farms of the Northwest Forest-Steppe of Ukraine. The phenomenon of incompatibility of crops, allelopathic soil fatigue and other biological factors that inhibited the growth of crop rotation productivity. Theoretical, methodological and practical bases of antierosion measures, which included the anti-erosion organization of the

13 Довідка про науково-дослідні установи сільського господарства Української РСР за 1953 р. Центральний державний архів вищих органів влади та управління України. Ф. Р-27. Оп. 18. Спр. 7874. Арк. 1-44.

14 Бойко П. І., Блащук М. І., Демиденко О. В. Сівозміни та родючість чорнозему Лівобережного Лісостепу : монографія. Сміла, 2019. 450 с. 
territory and the introduction of soil protection crop rotation ${ }^{15}$. Scientists have developed effective soil tillage systems, fertilizers, crop rotation under irrigation conditions, rational irrigation regimes of agricultural crops in different soil-climatic conditions. Measures to combat soil salinization and swamping; improving the quality of agricultural products, depending on the crops composition and alternation. Creation and preservation of multi-year hay-grazing and pasture lands of high productivity by introducing meadow crop rotation with different saturation of row crops in the Forest-Steppe of Ukraine.

At the beginning of the 1990s the researches of the scientific school for the first time in Ukraine introduced systematic research of the nitrogen cycle in the system «soil - fertilizer - plant - water - atmosphere» using a stable nitrogen isotope, parameters of symbiotic and non-symbiotic nitrogen fixation in field conditions. Under the guidance of V. O. Pastushenko more than 170 scientific works have been published, namely: the monographs: «Crop rotations in collective farms of Ukraine» (1959), «Soil erosion and measures to overcome it» (1961), «Crop rotations in Ukraine» $(1966,1972)$, «Intensive crop rotations of the Forest-Steppe and Polissya» (1975). His students have greatly expanded theoretical and methodological work on the improvement of grain agroecosystems in different soil-climatic conditions of Ukraine. One of the areas that has received extensive development in agriculture, was formed by the Candidate of Science I. H. Zakharchenko, who for the first time in Ukraine on a large scale has established a balance of nutrients in intensive grain crop rotations. Mentioned scientific direction has been expanded by the Candidate of Science of H. K. Medvid', who for the first time has developed the theoretical and methodological foundations of quantitative and qualitative estimation of profitable and expense balances of nitrogen in grain crop rotation ${ }^{16}$. The second direction, which received wide development in agriculture, was formed by Doctor of Sciences V. V.Kul'bida, who for the first time has established theoretical and methodological bases for the intensification and biologization of grain crop rotations by increasing the role of post-harvesting and post-mowing crops. This scientific direction has been enlarged by the Candidate of Sciences

\footnotetext{
${ }^{15}$ Науковий звіт Українського науково-дослідного інституту землеробства за 1965 р. Центральний державний архів вищих органів влади та управління Украйни. Ф. Р-27. Оп. 21. Спр. 34. Арк. 1-274.

16 Коваленко Н. П. Становлення та розвиток науково-організаційних основ застосування вітчизняних сівозмін у системах землеробства (друга половина XIX - початок XXI ст.) : монографія. Київ: ТОВ «Нілан-ЛТД», 2014. 490 с.
} 
I. H. Predko, who for the first time has identified the scientific and practical bases of intensive grain-row crop rotations for the Forest-Steppe of Ukraine.

The research on the improvement of the theoretical and methodological foundations for corn and other crops growing in the intensive specialized crop rotations of the Forest-Steppe of Ukraine was continued by the nearest student of V. O. Pastushhenko. Professor P. I. Boiko, who has headed the scientific school since 1992 carried out a comprehensive agrotechnical evaluation of corn precursors in accordance with the effect of factors of agriculture intensification ${ }^{17}$. The ecological factors of soil fatigue have been established under the influence of corn and other crops, namely: the formation of negative allelopathic soil effects and the toxicity of plants roots in their constant growth.

At the beginning of the $\mathrm{XXI}^{\text {st }}$ century, under Professor P. I. Boiko's guide researchers of the scientific school O. O. Artiushenko, V. O. Borodan', N. P. Kovalenko, V. V. Kul'bida both have developed theoretical and methodological bases and ecologically safe technologies of soil fertility reproduction and this process control system by means of rational land use and created the models of soil protection systems of agriculture using highly effective fertilizers and chemical melioration in the conditions of Forest-Steppe of Ukraine ${ }^{18}$. Biological and agroecological principles of organization of zonal agroecosystems, scientific and practical bases of long-term crop rotation for large farmlands of different specializations and highly specialized short-term crop rotation for farms have been established. They have determined the effectiveness of alternative agriculture with the maximum use of biological means of intensification, agricultural systems for soil protection from erosion in the Forest-Steppe of Ukraine ${ }^{19}$.

Professor P. I. Boiko for the first time has initiated comprehensive fundamental research on determining the influence of biological factors on soil fertility on crop rotation productivity, fertility and phytosanitary state of soil in order to overcome the negative effects soil fatigue. His student - the Director of the SEC «Institute of Agriculture of the NAAS», Academician V.F Kaminski has firstly substantiated the

\footnotetext{
17 Бойко П. І., Блащук М. І., Демиденко О. В. Сівозміни та родючість чорнозему Лівобережного Лісостепу : монографія. Сміла, 2019. 450 с.

18 Звіт про науково-дослідну роботу Українського науково-дослідного інституту землеробства за 1986-1990 pр. Науковий архів ННЦ «Інститут землеробства НААН». Оп. 2. Спр. 839. Арк. 1-501.

19 Звіт про науково-дослідну роботу Інституту землеробства УААН за 2001-2005 рр. Науковий архів ННЦ «Інститут землеробства НААН». Оп. 2. Спр. 938. Арк. 1-364.
} 
agrobiological bases of intensification of leguminous crop growing in crop rotations in the Forest-Steppe of Ukraine; has published more than 130 scientific works, and obtained 2 patents for his inventions. Professor P. I. Boiko's students have made a significant contribution to the elaboration of theoretical and methodological foundations of efficient agricultural crops alternation in grain - row rotations in the ForestSteppe of Ukraine: M. M. Nazarenko - corn for grain; K. M. Vishniakova - corn for grain and silage; Yu. I. Sologub - sugar beets; O. V. Yegorov - potatoes; O. Ye. Koretski, M. H. Furmanets' winter wheat; L. S. Kvasnits'ka - grain crops ${ }^{20}$. Professor P. I. Boiko has published more than 280 scientific works, including the monographs «Corn in intensive crop rotation» (1990), «Crop rotation and fertility of black soil of the Left-Bank Forest-Steppe of Ukraine» (2019); textbook «Ecological problems of agriculture» (2010). Numerous scientific and methodological publications are of a great importance, including the scientific work «Prediction humus level of black soils of Forest-Steppe of Ukraine depending on the application of crop rotation, fertilization and tillage» (2019) in publication «International Journal of Ecosystems and Ecology Science», which is included in the Web of Science international science and technology base.

At the beginning of the $\mathrm{XXI}^{\text {st }}$ century, the scientists solved the following tasks: scientific substantiation of theoretical and methodological foundations and practical implementation of crop rotation on the basis of soil fertility control, quantity and quality of harvest, economic and energy evaluation of mentioned measures. Improvement of agroecosystems with optimal placement of crops adapted to the soil-climatic conditions and specialization of farms. Development and implementation of grain crop rotation with different rotation for farms of wide specialization by means of cultural agroecosystems models creation, taking into account elements of organic farming ${ }^{21}$. Over 100 Candidates and Doctors of Science have been trained by the science school.

\footnotetext{
${ }^{20}$ Бойко П. І., Блащук М. І., Демиденко О. В. Сівозміни та родючість чорнозему Лівобережного Лісостепу : монографія. Сміла, 2019. 450 с.

21 Коваленко Н. П. Становлення та розвиток науково-організаційних основ застосування вітчизняних сівозмін у системах землеробства (друга половина XIX - початок XXI ст.) : монографія. Київ: ТОВ «Нілан-ЛТД», 2014. 490 с.
} 


\section{Achievements of Scientific Schools for Grain-Row Agroecosystems Improvement}

A well-known scientific school in Ukraine and outside the country for the development of grain-row agroecosystems in Forest-Steppe of Ukraine was founded in 1898 in the agricultural department of the Kyiv Polytechnic Institute (now the National University of Life and Environmental Sciences of Ukraine). Since its foundation Professor M. P. Chyrvinskii has established and Professor P. P. Sliozkin has developed the application of effective technologies for winter wheat and sugar beet growing in crop rotations with rational fertilizer systems use. Professor O. V. Klucharov has determined the efficiency of complex combination of soil cultivation and fertilization in grain - beet crop rotations application in the Forest-Steppe of Ukraine ${ }^{22}$.

Professor V. V. Kolkunov has made a great contribution to the development of the theoretical basis for effective grain crops and sugar beet growing in crop rotations in the conditions of insufficient moisture of the Forest-Steppe of Ukraine. Professor A. H. Michalowskii has firstly determined frost resistance of winter crops in crop rotations and developed their effective alternation with sugar beet. Professor A. H. Ternichenko has established effective winter rye growing in crop rotations and its best precursors. Professors O. Yu. Barabash, Eu. P. Votchal, I. M. Hudkov, H. I. Demydas' have carried out priority research on the determination of effective crop rotation with different saturations of cereals, row and forage crops. In the second half of the $\mathrm{XX}^{\text {th }}$ century, the scientific school received recognition for Professor's A. H. Michalowskii and his students' effective agricultural practices development and implementation for the rational use of field land according to the intensive farming system in the Forest-Steppe of Ukraine ${ }^{23}$. The nearest followers of A. H. Michalowskii's scientific traditions - Professors V. P. Hudz', V. M. Caliberda, E. F. Manoilenko have developed theoretical and methodological foundation for the introduction of mixed, post-harvesting and post-mowing crops in grain row crop rotation and their rational fertilization.

22 Діденко В. В. Нарис історії Національного аграрного університету (до 100-річчя заснування). Київ: Аграрна наука, 1998. 175 с.

23 Науковий звіт про виконання тематичного плану науково-дослідних робіт агрономічного факультету УСГА за 1962 р. Центральний державний архів вищих органів влади та управління Украӥни. Ф. Р-27. Оп. 20. Спр. 184. Арк. 1-320. 
Effective growing of high-yielding row crops in combination with winter wheat in grain - row crop rotations and the best precursors' determination for winter grain crops were worked out by Professor V. M. Caliberda ${ }^{24}$. He has determined the productivity of crop rotation sections, depending on the saturation of grains, sugar beet, post-harvesting and post-mowing crops; has established the most high-yielding crop rotation sections with fallow, occupied by fodder lupine and peas. He has also recommended the placement of winter grain crops after occupied fallows and green manure crops for the rational use of peat soils of dried bogs in the Forest-Steppe of Ukraine ${ }^{25}$.

The theoretical and methodological aspects of developing an effective fertilizer system in crop rotations have been developed by Academician P. A. Vlasiuk. He has determined the effectiveness of dunging and mineral fertilizers combination in sowing and basic fertilization ${ }^{26}$. Professor M. H. Horodnii has found effective use of organic and mineral fertilizers in specialized hemp crop rotations. Professor M. M. Horodnii has identified the effective fertilizer system with elements of biologization in different crop rotations. Professor M. K. Shikula has developed the basic model and implemented the soil protection system of agriculture with contourmelioration land management, has implemented the soil protection crop rotations to protect soil from erosion. Academician O. Yu. Barabash has established the effective alternation of vegetable crops in specialized crop rotations for different soil-climatic conditions of the Forest-Steppe of Ukraine $^{27}$.

At the beginning of the $\mathrm{XXI}^{\text {st }}$ century, priority research on the development of theoretical and methodological foundations of the protection measures integrated system for grain crops and sugar beet from weeds have been carried out by Professors I. V. Veselovskii, V. P. Hudz ${ }^{28}$. Researchers of the scientific school have determined the effectiveness of

\footnotetext{
24 Довідка від 30 грудня 1964 р. в ЦК КПУ про заходи з підвищення культури землеробства. Державний архів м. Київ. Ф. Р-1331. Оп. 3. Спр. 4515. Арк. 1-24.

25 План і звіт про науково-дослідну роботу кафедри загального землеробства УСГА за 1970 р. Державний архів м. Київ. Ф. Р-1331. Оп. 11. Спр. 161. Арк. 1-169.

${ }^{26}$ Науковий звіт факультету грунтознавства і агрохімії УСГА за 1962 р. Центральний державний архів вищих органів влади та управління Украӥни. Ф. Р-27. Оп. 20. Спр. 191. Арк. 1-309.

27 Діденко В. В. Нарис історії Національного аграрного університету (до 100-річчя заснування). Київ: Аграрна наука, 1998. 175 с.

28 Коваленко Н. П. Становлення та розвиток науково-організаційних основ застосування вітчизняних сівозмін у системах землеробства (друга половина XIX - початок XXI ст.) : монографія. Київ: ТОВ «Нілан-ЛТД», 2014. 490 с.
} 
growing corn and fodder beans on silage in row crop rotations, forage lupine - in field crop rotations; effective methods of soil cultivation have been established in combination with fertilizers in multiple grains-sugar beet rotations of the Forest-Steppe of Ukraine ${ }^{29}$. Professor V. I. Moiseienko has established the effectiveness of perennial grasses and their mixtures growing in the fodder crop rotations of the Right Bank Forest-Steppe of Ukraine by means of mineral fertilizers application.

Under the guidance of Professor S. P. Tanchik researchers of the scientific school O. Yu. Karpenko, O. P. Krotinov, Yu. P. Man'ko, V. M. Rozhko have directed their research on the ecological farming model development in the Forest-Steppe of Ukraine. Scientists have published more than 110 scientific works, namely: «Agriculture» (1996), "Agriculture with the basics of soil science and agrochemistry» (2007), "Adaptive systems of agriculture» $(2007)^{30}$. Over 80 Candidates and Doctors of sciences have been trained by the science school. At the beginning of XXI century, the scientists have solved the following tasks: development of effective agroecosystems for farms of different forms of ownership; formation of the integrated weeding control system for crops in different agroecosystems; application of modern adaptive farming systems: industrial, ecological, biological, soil protection and No-till farming system.

A well-known scientific school for the improvement of agroecosystems in the Forest-Steppe of Ukraine was established in 1911 at the Myronivs'ka selection and experimental station (now Mironovskyi Institute of Wheat named after V. M. Remesla of NAAS) ${ }^{31}$. From the beginning of its foundation by Professor S. L. Frankfurt, systemic studies were started to determine the effectiveness of application phosphorus oxide fertilizers in winter wheat in grain - beet rotations, namely: superphosphate and basic slag, as well as their aftereffects for sugar beet crops. The closest successor to S. L. Frankfurt's scientific traditions is Professor M. M. Tulaikov. He has determined the efficiency of manure application in grain - fallow crop rotations, improved the use of

29 Науковий звіт про виконання тематичного плану науково-дослідних робіт агрономічного факультету УСГА за 1962 р. Центральний державний архів вищих органів влади та управління Украӥни. Ф. Р-27. Оп. 20. Спр. 184. Арк. 1-320.

${ }^{30}$ Мельничук Д. О., Зубець М. В., Беренштейн Л. Ю. Становлення і розвиток аграрної освіти та науки в Україні (з найдавніших часів до сьогодення). Київ: НАУ, 2005. 224 с.

31 Довідка про науково-дослідні установи сільського господарства Української РСР за 1953 р. Центральний державний архів вищих органів влади та управління Украӥни. Ф. Р-27. Оп. 18. Спр. 7874. Арк. 1-44. 
phosphoric fertilizers: superphosphate and basic slag ${ }^{32}$. Professor O. M. Nadezhdin has introduced into production effective crop rotations with different saturations of sugar beet, winter wheat and rye, which were grown after clear and occupied fallow constantly using mineral fertilizers.

In the first half of the $\mathrm{XX}^{\text {th }}$ century one of the scientific school's directions was formed by O. K. Filipovskii, who, based on the results of occupied fallow efficiency determination in crop rotations, has established the best early harvesting crops in occupied fallow. Professors I. K. Bobyr, A. I. P'iatenko have identified the effective grain - beet crop rotations with 40-60\% saturation of grain crops and 10-40\% sugar beet saturation $^{33}$. Professors H. D. Bezvusii, M. H. Hupalo have developed grassland crop rotations to grow perennial grasses, effective alternation of spring barley and wheat in crop rotations, depending on sowing and fertilization methods. V. K. Blazhevskii, S. V. Sukhobrus have recommended for the production a complex of effective agrotechnical measures for corn growing. In the second half of the $\mathrm{XX}^{\text {th }}$ century, the Academician V. M. Remeslo established the efficiency of winter wheat (variety Myronivs'ka 808) growing in scientifically grounded crop rotations after occupied fallows. The Academician V. F. Saiko has introduced into production the varietal technology and free-field tillage in multiple crop rotations. V. M. Hryniov, M. A. Ilchenko have applied intensive winter wheat (variety Myronivs'ka 808) cultivation technology. V. I. Rusanov, A. M. Tverdokhlib have developed energy-saving, environmentally safe technologies for winter and spring grain crops growing in multiple crop rotations.

At the beginning of the XXI ${ }^{\text {st }}$ century the researchers of the scientific school V. P. Kavunets', V. V. Tkalych, O. I. Shevchenko created innovative high-efficient technologies of winter wheat growing of different varieties, winter and spring barley and spring wheat in crop rotations in conditions of the Forest-Steppe of Ukraine. The scientific school has published more than 650 scientific works, namely: «Program of activity of the central experimental station on sugar beet» (1912), «Historical review of the foundation, organization and operation of Myronivs'ka Selection

\footnotetext{
32 Миронівський інститут пшениці імені В. М. Ремесла НААН (1912-2012). За ред. В. С. Кочмарського. Миронівка, 2012. 816 с.

33 Коваленко Н. П. Становлення та розвиток науково-організаційних основ застосування вітчизняних сівозмін у системах землеробства (друга половина XIX - початок XXI ст.) : монографія. Київ: ТОВ «Нілан-ЛТД», 2014. 490 с.
} 
and Experimental Station» (1924), «Myronivs'ka Selection and Experimental Station, its task and labor: the materials of the station's work during 1912-1927» (1927). More than 60 Candidates and Doctors of Sciences have been trained by scientists. At the beginning of the $\mathrm{XXI}^{\text {st }}$ century the researchers' efforts of the scientific school were aimed at improving the system of different crop rotations and taking into account their intensification and biologization in market conditions. Substantiation of innovative ecologically safe technologies of competitive grain crops growing; the application of complex system of organic and mineral fertilizers in perennial grasses agroecosystems ${ }^{34}$.

Significant achievements in improving the grain - row agroecosystems in the Forest-Steppe of Ukraine were obtained by the researchers of the scientific school, which was formed in 1922 at the Research Institute of Selection (now the Institute of Bioenergy Crops and Sugar Beet of NAAS). Since its foundation by Professor V. V. Kolkunov it has been initiated systematic studies on the efficient cultivation of grain crops and sugar beet in grain - beet crop rotations ${ }^{35}$. In the middle of the $\mathrm{XX}^{\text {th }}$ century the successor of V.V. Kolkunov's scientific traditions Professor M. A. Hrekov identified the value of perennial grasses use in grain - beet crop rotations, as the basis of the grassland system of agriculture $^{36}$. He has published more than 100 scientific works devoted to the development of effective grain - beet crop rotations in the ForestSteppe of Ukraine. The most significant work among is the book «Beetroot breeding» (1951).

In the second half of the $X^{\text {th }}$ century the closest follower of A. M. Hrekov Professor V. F. Zubenko for the first time has established the economic efficiency of various types of crop rotations, saturated with grains, beans and row crops and revealed the possibility of further intensification of agricultural production. Scientist has published more than 200 scientific works, including recommendations on the effective agricultural crops rotation contained in the book «Scientifically grounded

\footnotetext{
34 Миронівський інститут пшениці імені $\quad$ В. М. Ремесла НААН (1912-2012). За ред. В. С. Кочмарського. Миронівка, 2012. 816 с.

35 Довідка про науково-дослідні установи сільського господарства Української РСР за 1953 р. Центральний державний архів вищих органів влади та управління Украйни. Ф. Р-27. Оп. 18. Спр. 7874. Арк. 1-44.

36 Цвей Я. П., Гоголь Л. О., Кісілевська М. О. Історичний шлях землеробської науки в буряківництві. Збірник наукових праць Інституту біоенергетичних культур і иукрових буряків. 2012. Вип. 13. С. 162-169.
} 
system of agriculture in Polissya and Western regions of Ukraine» $(1967)^{37}$. The second follower of M. A. Hrekov's scientific direction Candidate of Sciences I. S. Shkarednii has optimized the placement of crops in grain - beet crop rotations, depending on the tillage and fertilizers.

Valuable achievements of the scientific school are the efficiency determination of grain - beet crop rotations depending on the soil cultivation system, organic and mineral fertilizers use, irrigation, control of saltines and soil erosion, the use of herbicides, polymers, microbiological preparations $^{38}$. Scientists M. A. Hrekov, S. H. Kurbatov have developed and introduced grain - row crop rotations with 30-50\% saturation of sugar beets into production. M. F. Derevitskii has developed the methodology and determined ways to improve the accuracy of field experiment. I. V. Yakushkin has improved the classification of crop rotations.

Important achievements of the scientific school, that were developed in the future, were the change establishment of change in the microbial soil cenosis, depending on the presence of biological nitrogen and the use of organic and mineral fertilizers. Scientists I. A. Heller, V. I. Kanivets', A. V. Karbiievs'ka have found that the development of phosphatemitigating and cellulose-destroying bacteria depended on fertilizer systems, and mushrooms - on the presence of organic fertilizers: manure, straw. The great importance was the problem-solving of nutrients balance regulation in agroecosystems depending on the use of mineral and organic fertilizers and their biologization by such scientists as L. A. Barshtein, V. Ph. Zubenko, V. F. Panchenko, Ya. P. Tsvei, I. S. Shkarednii, V. M. Yakimenko ${ }^{39}$. They determined the effectiveness of agroecosystems biologization methods using grains and white mustard straw as green fertilizer for post-harvest planting.

At the beginning of the XXI ${ }^{\text {st }}$ century under Professor Ya. P. Tsvei's guide it has been theoretically substantiated and experimentally determined the scientific and practical aspects of black soils efficient use by means of rational grain-beet crop rotations, soil cultivation, ecological measures of

37 Коваленко Н. П. Становлення та розвиток науково-організаційних основ застосування вітчизняних сівозмін у системах землеробства (друга половина XIX - початок XXI ст.) : монографія. Київ: ТОВ «Нілан-ЛТД», 2014. 490 с.

38 Науковий звіт Всесоюзного науково-дослідного інституту цукрових буряків за 1962 р. Центральний державний архів вищих органів влади та управління Украӥни. Ф. Р-27. Оп. 20. Спр. 183. Арк. 1-72.

39 Цвей Я. П., Гоголь Л. О., Кісілевська М. О. Історичний шлях землеробської науки в буряківництві. Збірник наукових праць Інституту біоенергетичних культур і иукрових буряків. 2012. Вип. 13. С. 162-169. 
agroecosystems in the Forest-Steppe of Ukraine. Scientists have established methods for microbiological drugs using and the use of liquid fertilizers and microelements based on chelates. They have substantiated the necessity to use by-products of grain crops on biofuels, depending on the saturation of crop rotation with grains and row crops. Scientists have published the following scientific works, which are of great importance: «Crop rotations in beet-growing areas» (1969), «Agrotechnical bases of crop rotations» (1978), «Crop rotations are the basis of agriculture intensification» (1985), "The system of agriculture in beet growing» (1997) «Transformation of humus in different systems of agriculture» (1997), «Crop rotations, tillage and fertilization in beet-growing zones» $(2002)^{40}$. Over 70 Candidates and Doctors of Sciences have been trained by the scientific school. At the beginning of the XXI ${ }^{\text {st }}$ century the scientific school has intensified research in the following areas: substantiation of different crop rotations biologization, taking into account their saturation with grains and row crops; development of methods for soil cultivation minimization in short-term crop rotations; the establishment of the microbiological soil cenosis formation dependence on the fertilization and tillage system in the agroecosystems of the Forest-Steppe of Ukraine.

\section{CONCLUSIONS}

It can be concluded that the scientific schools that carried out research work in various soil - climatic conditions of the Forest-Steppe of Ukraine have made a substantial contribution to the development of research and effective introduction of national agroecosystems of different specializations. It has been clearly marked in their activities the main scientific theories and concepts genesis, traditions of scientific creativity, continuity of generations. It has been established that the main centers of their formation were the departments of higher education institutions and laboratories of research institutes, which played the role of leading centers for the development, accumulation and promotion of scientific knowledge about agroecosystems of various specializations.

On the basis of the system historical approach, a number of branch scientific schools for agroecosystems improvement for specialized farms located in different soil-climatic conditions of the Forest-Steppe of Ukraine

40 Коваленко Н. П. Становлення та розвиток науково-організаційних основ застосування вітчизняних сівозмін у системах землеробства (друга половина XIX - початок XXI ст.) : монографія. Київ: ТОВ «Нілан-ЛТД», 2014. 490 с. 
have been allocated. In particular, two scientific schools of grain specialization and three - grain-row, which were widely developed in the second half of the $\mathrm{XIX}^{\text {th }}$ and early $\mathrm{XX}^{\text {th }}$ centuries, due to the early development of these areas in agriculture. Researchers of the scientific schools have carried out economic, energy and environmental justification of agroecosystems using the systems of differentiated soil tillage, organic and mineral fertilizers and integrated protection of crops from weeds, diseases and pests. Scientists have developed different crop rotations system taking into account their intensification and biologization in market conditions for farmlands of different specialization. They have also determined the optimal ratio of high-yield crops, best precursors and return periods to the previous place of cultivation. It has been theoretically and methodologically substantiated the use of herbicides, growth regulators, microbiological preparation, liquid fertilizers and microelements in highly productive agroecosystems, methods of their biologization using straw of grain crops, post-harvesting and post-mowing crops.

\section{SUMMARY}

It has been established that at the beginning of the $\mathrm{XXI}^{\mathrm{st}}$ century the development of the agrarian sector of Ukraine was ensured by the effective agroecosystems introduction. They were based on the use of scientifically grounded structure of cultivated areas and specialized crop rotations with efficient alternation of different biological crop groups, rational fertilization and cultivation systems application, as well as environmentally safe measures. With their introduction, important practical tasks were solved in two directions: the reproduction of soil fertility and natural environment preservation, as well as providing the population of Ukraine with high-quality food.

For this purpose the peculiarities of branch scientific schools' activities on agroecosystems improvement for specialized farmlands located in different soil-climatic conditions of the Forest-Steppe of Ukraine have been determined in the article on the basis of the system historical approach. In particular, two scientific schools of grain specialization and three - grain-row, which were widely developed in the second half of the $\mathrm{XIX}^{\text {th }}$ and early $\mathrm{XX}^{\text {th }}$ centuries, due to the early development of these areas in agriculture. It has been determined that the precondition for their creation was theoretical knowledge accumulation, the availability of full 
value perspective research program, which was possible only with the establishment of branch higher educational institutions and research centers network.

In order to optimize agroecosystems the researchers of the scientific schools have economically, energetically and ecologically substantiated the application of intensive ecological measures for farmlands of different specialization taking into account their intensification and biologization in market conditions. It has been determined the effective crop rotations, the application of differentiated tillage systems, organic and mineral fertilizers and integrated protection, that has contributed to the soil fertility increase and agroecosystems productivity in different soilclimatic zones of Ukraine.

\section{REFERENCES}

1. Бойко П. І. Біологічна та екологічна роль сівозмін у землеробстві. Київ: Знання, 1990. 48 с.

2. Бойко П. І., Блащук М. І., Демиденко О. В. Сівозміни та родючість чорнозему Лівобережного Лісостепу : монографія. Сміла, 2019. $450 \mathrm{c}$.

3. Бойко П., Данилевский А. Координационное совещание. Земледелие. 1973. №10. С. 79.

4. Діденко В. В. Нарис історії Національного аграрного університету (до 100-річчя заснування). Київ: Аграрна наука, 1998. $175 \mathrm{c}$.

5. Довідка від 30 грудня 1964 р. в ЦК КПУ про заходи 3 підвищення культури землеробства. Державний архів м. Київ. Ф. Р-1331. Оп. 3. Спр. 4515. Арк. 1-24.

6. Довідка про науково-дослідні установи сільського господарства Української РСР за 1953 р. Центральний державний архів вищих органів влади та управління Украӥни. Ф.Р-27. Оп. 18. Спр. 7874. Арк. 1-44.

7. Звіт про науково-дослідну роботу Інституту землеробства УААН за 2001-2005 pp. Науковий архів ННЦ «Інститут землеробства НААН». Оп. 2. Спр. 938. Арк. 1-364.

8. Звіт про науково-дослідну роботу Українського науководослідного інституту землеробства за 1986-1990рp. Науковий архів ННЦ «Інститут землеробства НААН». Оп. 2. Спр. 839. Арк. 1-501. 
9. Карасюк I. М., Замаховська М. Ю. Уманська сільськогосподарська академія (1884-1999). Київ: Сільгоспосвіта, 1999. 47 с.

10. Коваленко Н. П. Становлення та розвиток науковоорганізаційних основ застосування вітчизняних сівозмін у системах землеробства (друга половина XIX - початок XXI ст.) : монографія. Київ: ТОВ «Нілан-ЛТД», 2014. 490 с.

11. Мельничук Д. О., З Зубець М. В., Беренштейн Л. Ю. Становлення і розвиток аграрної освіти та науки в Україні (з найдавніших часів до сьогодення). Київ: НАУ, 2005. 224 с.

12. Микулинский С. Р., Ярошевский М. Г. Школы в науке. Москва: Наука, 1977. 523 с.

13. Миронівський інститут пшениці імені В. М. Ремесла НААН (1912-2012). За ред. В. С. Кочмарського. Миронівка, 2012. 816 с.

14.Науковий звіт Всесоюзного науково-дослідного інституту цукрових буряків за 1962 р. Центральний державний архів вищих органів влади та управління Украӥни. Ф.Р-27. Оп. 20. Спр. 183. Арк. 1-72.

15. Науковий звіт про виконання тематичного плану науководослідних робіт агрономічного факультету УСГА за 1962 р. Центральний державний архів вищих органів влади та управління України. Ф. Р-27. Оп. 20. Спр. 184. Арк. 1-320.

16. Науковий звіт Українського науково-дослідного інституту землеробства за 1965 р. Центральний державний архів вищих органів влади та управління Украӥни. Ф. Р-27. Оп. 21. Спр. 34. Арк. 1-274.

17. Науковий звіт факультету грунтознавства і агрохімії УСГА за 1962 р. Центральний державний архів вищих органів влади та управління України. Ф. Р-27. Оп. 20. Спр. 191. Арк. 1-309.

18. Онопрієнко В. І., Ткаченко В. М. Історія української науки. Київ, 2010. 652 с.

19. План і звіт про науково-дослідну роботу кафедри загального землеробства УСГА за 1970 р. Державний архів м. Київ. Ф. Р-1331. Оп. 11. Спр. 161. Арк. 1-169.

20. Храмов Ю. А. История формирования и развития физических школ на Украине. Киев: Феникс, 1991. 216 с.

21. Цвей Я. П., Гоголь Л. О., Кісілевська М. О. Історичний шлях землеробської науки в буряківництві. Збірник наукових пращуь 
Інституту біоенергетичних культур $і$ иукрових буряків. 2012. Вип. 13. С. 162-169.

22. Юркевич Є. О., Коваленко Н. П., Бакума А. В. Агробіологічні основи сівозмін Степу України : монографія. Одеса: Одеське видавництво «ВМВ», 2011.240 с.

Information about the author: Kovalenko N. P.,

Doctor of Historical Sciences, Senior Researcher, Chief Researcher of Science Sector of Institute of History of Agrarian Sciences, Education and Technique, National Scientific Agricultural Library of National Academy of Agrarian Sciences of Ukraine, 10, Geroiv Oborony St., Kyiv, 03127,Ukraine 


\section{STAGES OF POULTRY FARMING DEVELOPMENT IN UKRAINE OF THE SECOND HALF OF 20th - AT THE BEGINING OF THE 21st CENTURIES}

\section{Melnyk V. V.}

\section{INTRODUCTION}

The poultry industry in Ukraine is currently at the forefront of animal husbandry. In search of the effective ways of further development of this industry in Ukraine, a detailed rethinking of the accumulated advanced scientific experience of poultry farming in the historical retrospective is relevant. In 1919, M.F. Ivanov in a clear sequence has put arguments forward evidence of the benefits and necessity of development of poultry farming ${ }^{1}$.

In Ukraine, in the period 1923-1928, the number of poultry increased in general (with certain fluctuations over the years) ${ }^{2}$. The possibilities of the republic for the export of poultry products also expanded. In particular, during the 1924-1926, more than a thousand carts of eggs had exported to Germany, England and Austria ${ }^{3}$.

Therefore, the need to increase the production of poultry and improve its profitability was obvious. In order to increase the quantity and thus reduce the cost of poultry production, it was necessary to study the ways of poultry feeding and keeping, to find cheap feeds, and so on. That is, the poultry industry needed scientific support, and in 1930 the Ukrainian Scientific Research Institute of Poultry was organized in the Ukrainian SSR, which subsequently undergone reorganization and was transformed into a Ukrainian Scientific Research Station of Poultry, and then, in 1959, into Ukrainian Scientific Research Institute of Poultry again ${ }^{4}$.

\footnotetext{
${ }^{1}$ Иванов М. Ф. Сельскохозяйственное птицеводство. Харьков: Союз, 1919. 225 с.

2 Центральний державний архів вищих органів влади і управління України (далі ЦДВО). Ф. 27. Оп. 8 л. Спр. 35. Арк. 33.

${ }^{3}$ ЦДАВО. Ф. 290. Оп. 4 л. Спр. 31. 23-24 арк.

4 Український науково-дослідний інститут птахівництва / відп. ред. М.В. Дахновський. Київ: Видавництво УАСГН, 1961. 83 с.
} 
But the rapid development of poultry farming in Ukraine began only in the second half of the $20^{\text {th }}$ century, starting with its transfer to an industrial basis in accordance with the resolution of $1964^{5}$.

In the historiography of poultry farming development for researching period there are publications on social, economic and political preconditions of establishment of industrial poultry farming ${ }^{6}$; scientific, organizational, and methodological activities of the Ukrainian Scientific Research Institute of Poultry ${ }^{7}$; scientific and organizational principles of the development of artificial egg incubation ${ }^{8}$ in the Ukrainian SSR in the second half of the $20^{\text {th }}$ century, the development of poultry farming in Ukraine during the period of independence ${ }^{9}$ and others.

Taking into account the aforementioned, the purpose of our work is to develop a periodization of poultry farming development in Ukraine in the second half of the $20^{\text {th }}$ - the beginning of the $21^{\text {st }}$ centuries. At the same time, we have identified two main stages: the first stage is the development of poultry farming in the Ukrainian SSR in the second half of the $20^{\text {th }}$ century; the second stage is the development of poultry farming in the independent Ukraine.

\section{Development of Poultry Farming in the Ukrainian SSR in the 50's -80 's of the $20^{\text {th }}$ Century}

To characterize the stage of development of poultry farming in the Ukrainian SSR in the second half of the $20^{\text {th }}$ century, we have identified several periods that covered certain chronological boundaries: the first 1951-1964, the second - 1964-1971, the third - 1971-1982 and the fourth - 1982-1991.

The first period (1951-1964) precedes the transfer of poultry farming to an industrial basis in accordance with the resolution of the Council of Ministers of the USSR and the Central Committee of the CPSU of

5 Об организации производства яиц и мяса птицы на промышленной основе. Постановление Совета Министров СССР и Центрального Комитета КПСС от 3 сентября 1964 г., № 740. Свод законов СССР. Москва: Известия. 1985. Т. 7. С. 512-517.

${ }^{6}$ Фисинин В. И. История птицеводства российского. М.: Хлебопродинформ, 2016. Т. 2. 348 с.

7 Український науково-дослідний інститут птахівництва / відп. ред. М.В. Дахновський. Київ: Видавництво УАСГН, 1961. 83 с.

8 Мельник В. В. Теоретико-методологічні та науково-організаційні засади розвитку штучної інкубації в Українській РСР У 1964-1991 роках. Гілея : науковий вісник, зб. наук. праць. Київ, 2019. Вип. 145(6). С. 99-102.

${ }^{9}$ Melnyk V. Development of poultry farming of Ukraine in the period of independence. Sciences of Europe. 2019. Vol.6. № 40. P. 45-48. 
September 3, $1964^{10}$. In the beginning of the second half of the $20^{\text {th }}$ century, poultry was kept mainly in collective farms and private farms. The population provided day-old young incubator-poultry stations, which functioned in all regions of the Ukrainian SSR.

The production of poultry eggs and meat was mostly seasonal. The focus was on egg production and its bigger percentage produced in households, although it gradually decreased: from 88.5 in 1951 to 85.0 in $1961^{11}$. The egg production in households of the public sector, namely, collective and state farms and other state enterprises, increased.

The mechanization and automation of labor-intensive processes in poultry farms was low. Not all collective and state farms were electrified. So, in 1958 the number of collective farms that used electricity was 59\%, and state farms $-96 \%{ }^{12}$.

Goose, duck and turkey farming developed for meat production. Goose farming was a traditional branch in Ukraine, because the geese use pasture and fodder well, that allows to get cheap natural feed. However, in this period, ducks were the main species of poultry for meat production. Ducks were bred only in those poultry farms, which were located near the ponds, lakes and other water reservoirs. At the same time, ducks, like geese, used cheap natural feed; it contributed to increasing the profitability of the poultry meat production. The type of poultry feeding was mainly combined. The advantage was given to the use of grain and wet blends.

In addition to concentrated feed juicy feed namely potatoes, beets, carrots, green alfalfa, etc., were also used for poultry feeding. In the summer, for young waterfowl keeping the sheds were used near the water reservoirs, as well as the premises, which got free after cattle grazing on the pastures.

However, the problem of increasing the production of meat was not solved by the application of extensive methods of poultry keeping. It was necessary to provide year-round production. Thus, in 1960, the state farm Yagotynskyi was established in the Kyiv region, where the annual production of duck meat on an industrial basis was organized for the first

10 Об организации производства яиц и мяса птицы на промышленной основе. Постановление Совета Министров СССР и Центрального Комитета КПСС от 3 сентября 1964 г., № 740. Свод законов СССР. Москва: Известия. 1985. Т. 7. С. 512-517.

${ }^{11}$ Народне господарство Української РСР в 1964 році : статистичний щорічник. Київ: ЦСУ УРСР «Статистика», 1965. 694 с.

12 Там само. 
time not only in the Ukrainian SSR, but and in the former USSR ${ }^{13}$. The state farm introduced a number of progressive methods of conducting industrial duck farming: feeding of ducklings and adult ducks with dry fodder mixes; two-time acquisition of a female stock in the course of a year, which allowed to raise the average annual egg laying; whole-year growth of duck for meat without using ponds; shortened growing period of ducks, etc.

Turkeys were also used for meat production. Mainly the turkeys were kept in poultry farms, where was also another poultry, mostly chickens. However, in the Ukrainian SSR already in the early 50's, poultry farms Starynska began to specialize on turkey farming ${ }^{14}$. Subsequently, it became the most powerful farm in the USSR.

For the production of chicken, they raised hens of meat and egg breeds and hybrid poultry as a result of cross-breeding from different breed lines. Chicken meat was also an additional production in farms specializing in the food egg production.

To solve the problem of increasing the production of meat, it was necessary to develop broiler production. It evidenced by the experience of other countries of the world, which constantly studied in the USSR. Already in the late 50's a year-round breeding of chickens for meat began also to introduce in the Ukrainian SSR.

The main center of scientific and methodological support for the development of poultry farming in the Ukrainian SSR was the Ukrainian Experimental Station of Poultry, reorganized in 1959 into the Ukrainian Scientific Research Institute of Poultry. In the same year, this institution received the breeding poultry farm "Krasny" in the Crimean region as a research farm. At this experimental base of the Ukrainian Scientific Research Institute of Poultry in the early 60's, a large female breeding stock of meat and egg chicken breeds, necessary for the production of meat chickens by crossing, was created. However, in order to develop broiler production, in 1962, in a research farm - a farm "Krasnyi", the first experimental broiler farm in the USSR was put into operation ${ }^{15}$.

${ }^{13}$ Божко П. Е. Сенников А. А. Производство утиного мяса в совхозе «Яготинский». М.: Колос, 1965. $152 \mathrm{c}$.

14 Литвинец Г. М. Старинская птицефабрика - специализированное индейководческое хозяйство. Птицеводство. 1962. № 3. С. 21-23.

${ }_{15}$ Марчик В., Бронфман Е. Бройлерная фабрика в содружестве с колхозами. Птицеводство. 1970. № 9. C. 12-13. 
In the researching period, A.U. Bikhovets made a significant contribution to the development of artificial incubation of poultry egg ${ }^{16}$. Important is the development of a scientist on the cooling of goose and duck eggs during its incubation, regimes and techniques for the incubation of eggs of meat and egg chicken breeds, and turkeys. During this period the achievements of Ukrainian scientists of the Department of the Poultry Selection and Breeding of the Ukrainian Scientific Research Institute of Poultry headed by M.V. Dubovsky, where I.S. Skuratov, L.M. Belov, M.G. Kurdiukov, T.S. Len, V.I. Butovska, R.K. Yevtyshenko and others worked, were very important ${ }^{17}$. Local poultry groups, namely Poltava local groups of chickens, Clayey Gray, White and White-Breast ducks, Romanian geese, were widely used as source material for selection.

By that time, scientists used the principles of the Michurin doctrine of the heredity of organisms and their variability in selection and breeding work. Ukrainian Gray, Clayey and White duck breeding groups were created by Ukrainian scientists without using interbreeding with other breeds solely by selection and creation of the best conditions of feeding and keeping. An important achievement of Ukrainian scientists on goose selection and breeding is creation of a Large Gray goose breed on the basis of the experimental farm "Birky", which was officially approved in $1956^{18}$.

For the production of chicken eggs and meat, hybrid poultry getting from interbreeding of various breeds were increasingly used. In the late 50 's the theoretical foundations for the chicken hybridization developed N.V. Dubovskyi， M.V. Dahnovskyi， M.O. Demchenko, M.G. Kurdiukov and M.V. Dubovskyi, which studied the productive qualities of the chicken hybrids of different breeds for several years. They have found that the hybrids from the crossing Poltava Clayey chickens with Russian White one dominated Pure-Bred Russian White bread on egg production, live weight and viability. It was necessary to use hybrid chickens for whole-year breeding of chickens for meat. In this regard, in 1959, the Department of Selection and Breeding of the Ukrainian Scientific Research Institute of

16 Библиографический указатель печатных работ сотрудников Украинского научноисследовательского института птицеводства (1930-1980)/ под общ. ред. А.В. Шомина. Харьков, 1983. $102 \mathrm{c}$.

17 Український науково-дослідний інститут птахівництва / відп. ред. М.В. Дахновський. Київ: Видавництво УАСГН, 1961. 83 с.

18 Український науково-дослідний інститут птахівництва / відп. ред. М.В. Дахновський. Київ: Видавництво УАСГН, 1961. 83 с. 
Poultry started work on the creation of faster-growing meat chickens (broilers) ${ }^{19}$.

Research on poultry feeding were due to the combined type of feeding widespread by that time, which used both dry grain mixtures, and wet. In particular, I.S. Skuratov studied the use of forage lupine, as well as corn cobblers and silage in poultry feeding. The influence of silage on the productivity of poultry was also investigated by I.Ya. Titskyi ${ }^{20}$. S.A. Vodolazhchenko researched the influence of fodder antibiotics on the quality of incubation eggs and chicks, as well as the growth and efficiency of chicken feed use for meat production ${ }^{21}$.

The V.V. Khaskin work was devoted to the problems of the poultry physiology of feeding, who researched the relationship nitrogen and energy metabolism in the ontogenesis of chickens ${ }^{22}$.

In the Ukrainian Scientific Research Institute of Poultry, the problems of poultry feeding were decided by the staff of the Department of Poultry Feeding and Keeping. One of the most significant works of the department is the development of a system of massive duck breeding on the water reservoirs, since the presence of a large number of water reservoirs with fresh water in the republic, rich in natural forages of plant and animal origin, contributed to the keeping of large groups of ducks there. Indeed, duck breeding for meat production by an intensive method at that time has not yet become significantly widespread due to the lack of sufficient quantities of protein fodders of animal origin, necessary for the provision of complete poultry feeding.

M.V. Dakhnovskyi developed a method of duck breeding in fresh and marine waters and showed its effectiveness, since the poultry used cheap natural food at this way ${ }^{23}$.

Important are also the developments of systems and methods of poultry keeping of Ukrainian scientists. In consequence of the

${ }^{19}$ Там само.

20 Библиографический указатель печатных работ сотрудников Украинского научноисследовательского института птицеводства (1930-1980)/ под общ. ред. А.В. Шомина. Харьков, 1983. $102 \mathrm{c.}$

21 Библиографический указатель печатных работ сотрудников Украинского научноисследовательского института птицеводства (1930-1980)/ под общ. ред. А.В. Шомина. Харьков, 1983. $102 \mathrm{c}$

${ }^{22}$ Хаскін В. В. Деякі питання взаємозвязку азотстого та енергетичного обміну в онтогенезі курей. Птахівниитво: наукові праиі К.: УАСГ, 1961. Т. 9, Вип. 1. С. 113-122.

23 Дахновський М. В. Ефективність вирощування качок на морських і прісних водоймах. Вісник с.-2. науки. 1959. № 2. С. 53-57. 
developments of the Department of Mechanization of the Ukrainian Scientific Research Institute of Poultry, for the first time in Ukraine, a large-sized poultry house built for several thousand chickens in the experimental farm "Birky". The technology of keeping egg laying hens in a large poultry house on a deep unchanging litter with the placement of the entire inventory at the stand and the maintenance of the poultry from the work passage was offered by M.V. Dahnovskyi ${ }^{24}$.

The second stage of the development of poultry farming in Ukraine in the second half of the $20^{\text {th }}$ century covers the period 1964-1971. Its beginning is due to the approval of the resolution of the Council of Ministers of the USSR and the Central Committee of the CPSU of September 3, 1964, on the transfer of poultry farming to an industrial basis $^{25}$. After the resolution, poultry farming in the Ukrainian SSR began to develop at a rapid pace.

The large-scale poultry farms, as well as specialized farms of collective and state farms have become the organizational form of intensive industrial poultry farming. Thus, on the basis of the state-owned plant «Yuzhnyi» one of the largest poultry farm for the chicken food eggs production «Yuzhna» of the Crimean region was organized in $1965^{26}$.

Due to the intensification of the specialization of farms, egg production in collective and state farms, other state enterprises increased by 3.6 times in 1971 compared to $1965^{27}$.

Under the leadership of the scientists of the Ukrainian Scientific Research Institute of Poultry at the state farm Krasnyi, the technology of chicken broiler breeding introduced for the first time not only in the Ukrainian SSR, but also in the Soviet Union as a whole.

With the development of this technology, the production of meat broilers has increased in the farm, and the indicators of economic efficiency have improved. For example, from 1967 to 1969, the profitability of meat production increased by 5.8 times. In consequence of the development of the broiler industry, the production of poultry meat has

\footnotetext{
24 Український науково-дослідний інститут птахівництва / відп. ред. М.В. Дахновський. Київ: Видавництво УАСГН, 1961.83 с.

25 Об организации производства яиц и мяса птицы на промышленной основе. Постановление Совета Министров СССР и Центрального Комитета КПСС от 3 сентября 1964 г., № 740. Свод законов СССР. Москва: Известия. 1985. Т. 7. С. 512-517.

26 Хачирашвили Г., Шперлинг М. Укреплять технологическую дисциплину, повышать рентабельность производства. Птицееводство. 1966. № 1. С. 7-9.

27 Народное хозяйство Украинской ССР в 1973 году : статистический ежегодник. Киев: «Статистика», 1974. 584 с.
} 
increased significantly in Ukraine as a whole. In 1971 compared with 1965 , poultry meat was produced by 1.7 times more ${ }^{28}$.

However, in the future, duck farming also developed and became an important reserve for the industrial production of poultry meat. Popularization of the experience of poultry farm Yagotinska, where in the early 60's the first time technology of growing ducks for meat without the use of water reservoirs was mastered, contributed to the rapid development of this industry in Ukraine ${ }^{29}$. This farm has become a school of advanced experience in industrial production of duck meat.

There was a need to put into operation new poultry farms and other state poultry farms, the introduction of advanced technologies for intensification of the poultry industry. In this regard, in 1971, a resolution "On measures to further increase the production of eggs and poultry meat on an industrial basis" was approved ${ }^{30}$. In accordance with its decisions, it was required to use lightweight combined and other modern designs of industrial poultry farming for the construction of poultry houses, to create favorable conditions for the use of full-fodder feed in poultry feeding.

It should be noted that during 1964-1971 the basic scientific and methodological support for the development of the poultry industry in Ukraine was also carried out by the Ukrainian Scientific Research Institute of Poultry.

Scientists of the Institute have developed a number of recommendations on the breeding of broilers, including for collective and state farms, the organization of specialized poultry farms for the production of chicken eggs, for raising the productivity and breeding qualities of poultry, as well as for the production of combined silage ${ }^{31}$. In the period of our research, the special attention of scientists attracted advances in the development of the broiler industry, since this particular direction allows us to solve the problem of meat production in Ukraine at present.

\footnotetext{
28 Народное хозяйство Украинской ССР в 1973 году : статистический ежегодник. Киев: «Статистика», 1974. 584 с.

${ }^{29}$ Божко П. Е. Сенников А. А. Производство утиного мяса в совхозе «Яготинский». М.: Колос, 1965. 152 c.

${ }^{30} \mathrm{O}$ мерах по дальнейшему увеличению производства яиц и мяса птицы на промышленной основе. Постановление Центрального Комитета КПСС и Совета Министров СССР от 26 февраля 1971 г., № 165. Свод законов СССР. Москва: Известия, 1985. Т. 7. С. 517-519.

31 Библиографический указатель печатных работ сотрудников Украинского научноисследовательского института птицеводства (1930-1980)/ под общ. ред. А.В. Шомина. Харьков, 1983. $102 \mathrm{c}$.
} 
So Yu.N. Batyuzhevskyi and I.Ya. Titskyi have developed full-fodder feed for broilers. S.A. Vodolazhchenko paid attention to the feeding of broilers, as well as the use of protein feeds made from poultry waste. The scientist continued research on the influence of fodder antibiotics on the organism of the poultry, the study of the mechanism of its action. Significant contribution to the development of artificial incubation were the results of research conducted by V.O. Brestslavets, who during this period studied the influence of hens' age on the physical and chemical properties and quality of eggs, embryogenesis and post-embryonic development of chickens. A.U. Bykhovets continued to improve the methods of technology for the incubation of poultry eggs, however the most of his research was aimed at improving the modes and technology of incubation of meat chicken eggs ${ }^{32}$.

In this period, the interlinear hybridization of chickens in Ukraine becomes the main method of obtaining broiler chickens. Selection work was carried out on the creation of domestic specialized lines for the production of broiler chickens, but at the same time they imported poultry from abroad. P.M. Sliusar studied the dynamics of the tribal and productive qualities of different lines of chickens of Cornish and Plymutrok White breeds, and assessed its the combination ${ }^{33}$. So, already at that time scientists began to use lines of Cornish and Plymutrok White breeds as parental forms for hybrid broilers creation.

The next (third) stage of poultry development covers 1971-1982. The upper limit of this period is related to the approval the Food Program of the USSR for the period until 1990 in May of $1982^{34}$. One of the outstanding scientific achievements in this period in the development of egg poultry farming was that, as a result of many years of work with the use of poultry of foreign selection, scientists from the Ukrainian Scientific Research Institute of Poultry created the "Birky-I" and "Birky-II" crosses. Hybrid egg-laying hens of these crosses were well adapted to the conditions of cage keeping ${ }^{35}$.

\footnotetext{
32 Там само.

33 Слюсар П. М. Селекція ліній курей порід корніш і плімутрок в процесі їх акліматизації. Птахівництво: міжвід. темат. наук. зб. Київ: Урожай, 1969. Вип. 8. С. 31-37.

34 Продовольственная программа СССР на период до 1990 года и меры по ее реализащии : материалы майского Пленума ЦК КПСС 1982 г. Москва: Политиздат, 1984. 111 с.

${ }^{35}$ Косенко Н. Ф., Сапронова Н. И., Ольховик Л. А. Методические рекомендации по использованию яичных кроссов «Борки-І» и «Борки-ІІ». Харьков, 1978. 10 с.
} 
Egg production in collective and state farms, other state enterprises of Ukraine in 1981 compared with 1971 increased by 2.3 times $^{36}$.

Already at the beginning of the 70s, Ukraine has gained considerable experience in organizing meat broilers production in poultry farms of the public sector. Successful development of broiler production depended largely on the organization of a number of breeding poultry farms for meat chickens breeding. The maximum indexes of poultry productivity at its breeding for meat at the lowest feed costs per unit increment of live weight provided of hybrid chicks raising, which obtained by crossing the connecting lines.

Chicken broilers were grown mainly on the floor on deep litter, but already in the early 70 's of the $20^{\text {th }}$ century scientists developed a method of its cage keeping. However, at that time, there has not developed a specialized cage battery for the keeping of broilers yet. The effectiveness of broiler keeping in the cages studied using home-made and reconstruction cages ${ }^{37}$.

Solving the problem of poultry meat providing of Ukrainian population particular attention was given to turkey farming. For example, in order to increase the number of turkeys in 1977, they planned to put into operation the Golovuriv breeding poultry plant and the Verkhniodniprovskyi reproducer ${ }^{38}$.

In general, in Ukraine there was a tendency to increase the production of poultry meat by 1.6 times in 1981 compared with $1971^{39,40}$.

Scientists of the Ukrainian Scientific Research Institute of Poultry continued research on various areas of poultry farming. A.B. Baidevaliatov conducted a series of experimental works that solved the problems of veterinary and sanitary measures in poultry and prophylaxis of poultry diseases, in particular, through its immunization; K.O. Bahmet devoted his scientific papers to the problems of hygiene in poultry houses; I.Yu. Bezrukava, I.M. Doroshko, E.S. Ostrovskaya, B.V. Litovchenko, V.F. Nesterenko, S.E. Brodetzka, V.F. Ivashchenko worked on the

36 Народное хозяйство Украинской ССР в 1973 году : статистический ежегодник. Киев: «Статистика», 1974. 584 с.

${ }^{37}$ Куров Ю. А. Птахівництво на промисловій основі. Київ: Урожай, 1973. 80 с.

${ }^{38}$ Коваленко А. Развитие мясного птицеводства на Украине. Птицеводство. 1977. № 8. С. 7-9.

${ }^{39}$ Народне господарство Української РСР у 1984 році : стат. щорічник / відп. за вип. Б. А. Сівко. Київ: Техніка, 1985. 406 с.

40 Народное хозяйство Украинской ССР в 1973 году : статистический ежегодник. Киев: «Статистика», 1974. 584 с. 
development of vaccine against viral hepatitis of ducklings; research of Yu.N. Batiuzhevskyi, S.A. Vodolazhenka, V.F. Caravanshenko, Yu.M. Nasonova, V.I. Konovalova, T.Ya. Sopozhnikova and others were aimed on improving the rationing of poultry feeding, solving the problem of poultry providing with highly protein-based animal feeds, proved the efficiency of calculating the recipes of mixed fodders using an electronic computer, etc.

The papers of O.T. Hadiuchko, G.T. Kovalenko, V.P. Kovalenko, Yu.V. Bondarenko, I.A. Stepanenko, V.D. Lukianova, O.D. Podstreshnyi, V.O. Sergeiev, V.D. Sergeiev devoted to breeding work. V.I. Bessulin, I.K. Reut, M.I. Sakhatskyi, O.P. Bondarenko and others developed methods of artificial insemination of poultry, mainly turkeys; V.O. Breslavets, V.O. Lukianov and others studied methods of long-term storage of eggs. A.U. Bykhovets, and O.M. Mikhailenko investigated the embryonic viability of the poultry, developed methods for improving the quality of eggs and the modes of incubation; A.A. Popov, L.G. Prokudina, P.M. Locksmith and others paid attention to the technological methods of poultry keeping ${ }^{41}$.

The fourth period of development of poultry farming covers the period 1982-1991. This period ends with the collapse of the USSR and the acquisition of Ukraine as an independent state.

Poultry farming continued to develop. The egg production in this period increased until 1988, and poultry meat until $1989^{42}$. In the future, there was a decrease in production of this product. At the same time, in $1991^{43}$ compared with $1981^{44}$ in all categories of farms, poultry meat production increased by 1.2 , and eggs decreased by $0.4 \%$, however, in public sector farms, the production of eggs increased by $0.8 \%$. For the production of eggs, hybrid poultry continued to be used, and at the same time, poultry farms in Ukraine began to spread the poultry cross of various types of foreign selection.

\footnotetext{
41 Библиографический указатель печатных работ сотрудников Украинского научноисследовательского института птицеводства (1930-1980)/ под общ. ред. А.В. Шомина. Харьков, 1983. $102 \mathrm{c}$.

42 Народне господарство Україніської РСР у 1990 році : стат. щорічник/від. за вип. В. В. Самченко. Київ: Техніка,1991. 496 с.

${ }^{43}$ Народне господарство Української РСР у 1991 році : стат. щорічник /від за вип. В.В. Самченко. Київ: Техніка, 1992. 468 с.

${ }^{44}$ Народне господарство Української РСР у 1984 році : стат. щорічник / відп. за вип. Б. А. Сівко. Київ: Техніка, 1985. 406 с.
} 
Although the main direction in the development of meat poultry farming was broiler production, it was important to have a duck farming. Due to the proliferation of intensive meat duck breeding, the share of duck meat in the Ukrainian SSR in the late 1980`s exceeded 20\% (from the total amount of poultry meat $)^{45}$.

The research of the scientists of the Ukrainian Scientific Research Institute of Poultry, which remained at the forefront of scientific support for the development of poultry farming in this period, aimed at solving the problems of poultry feeding and keeping, egg incubating, artificial insemination, selection and breeding work, disease prevention, veterinary and sanitary measures in poultry houses etc.

In particular, D.S. Cherniatin studied the poultry productivity for using rations based on heat-treated soybeans; P.F. Suray investigated the content of vitamins in organs and tissues of poultry and the effectiveness of various products of vitamin E; G.D. Shabelnik studied the effectiveness of replacing the protein of animal origin with herbal alfalfa flour; Yu.N. Batyuzhevskyi, M.M. Lemesheva proved the effectiveness of the use of limited feeding of repair turkeys.

N.I. Bratyshko determined the biological availability of B vitamins from feed of microbiological synthesis for chicken broilers; E.A. Duiunov, Yu.O. Riabokon, O. Hadiuchko developed the ways to increase the fertility of the turkeys of maternal lines of parental forms; V. D. Lukianova, T.V. Ivanova, V.P. Kovalenko solved the problem of safe the effect of multiple heterosis in poultry farming; V.I. Besulin, P.M. Karkach, M.I. Sakhatskyi, O.V. Tereschenko improved the methods of deep freezing of semen of poultry male and other ${ }^{46}$.

The organization of breeding work is an integral part of the technological process for the production of poultry eggs and meat, and therefore the scientists of the Ukrainian Scientific Research Institute of Poultry developed a plan for selection and breeding work in the poultry industry of the Ukrainian SSR for 1986-2007 and up to 2000.

Thus, it should be noted, the significant development of poultry farming in the second half of the $20^{\text {th }}$ century in the Ukrainian SSR was its transfer into an industrial base, scientific and methodological support provided by scientists of the Ukrainian Scientific Research Institute of Poultry.

\footnotetext{
${ }^{45}$ Кадура М. І., Пономарьова Ж. В., Шищенко Є. П. Виробництво качиного м’яса на інтенсивній основі. К.:Урожай, 1988. 96 с.

46 Друковані праці співробітників Державної дослідної станції птахівництва НАAН за 1981-2016 роки : [бібліографічний покажчик] / А.П. Пономарьова. Бірки, 2016. 211 с.
} 


\section{Development of Poultry Farming in Ukraine at the Beginning of the $21^{\text {th }}$ Century}

The second stage of the development of poultry farming in Ukraine in the 90 s of the $20^{\text {th }}-$ the beginning of the $21^{\text {th }}$ century is the period of independence. At present, the poultry industry in Ukraine is one of the leading directions. However, in the 90s, after the collapse of the USSR, a general economic crisis took place in Ukraine, which also negatively affected poultry farming. At the same time, the analysis of statistical data shows that during 1991-1997 the number of poultry was rapidly decreasing in farms of all categories.

However, in 1998, there was even some increase in the number of poultry and this indicator had almost stabilized by $2001^{47}$. During 2002-2014, there was an increase in the number of poultry, and in the future, due to political changes in Ukraine, the number of poultry taken into account without the temporarily occupied territory of the Autonomous Republic of Crimea, the city of Sevastopol and part of the temporarily occupied territories in the Donetsk and Luhansk regions. In this regard, during 2014-2015, the number of poultry in Ukraine has started to decrease again, the livestock has stabilized and in 2018, it began to recover (to increase). The egg and meat production in Ukraine during the times of independence had almost the same tendency as the dynamics of the poultry stock.

In the new market conditions, poultry managers began buying poultry of modern crosses, equipment, feed supplements and veterinary drugs in western countries. This has enabled, since 1998, to increase the production of poultry eggs and meat. However, the rebirth of poultry farming in Ukraine accompanied by the import of poultry of egg and meat crosses from abroad.

As a result, the part of poultry crosses of domestic breeding began to decrease. Thus, in the early 2000's, the crossing of egg chickens "Birky-2M" and "Birky-117" of Institute of Poultry of Ukrainian Academy of Agrarian Sciences (UAAS) turned out to be not competitive compared to the widespread autosex foreign crosses. In connection with this, tribal work with these crosses was discontinued and breeding work with other genetic resources was expanded ${ }^{48}$.

\footnotetext{
${ }^{47}$ Державна служба статистики України URL: http://ukrstat.gov.ua/ (дата звернення 25.05.2019).

${ }^{48}$ Степаненко I. А., Коваленко Г. Т., Іванова Т. В., Гадючко О. Т., Ваврійчук Т. В., Луніна Л. А. Дослідне господарство «Борки»: племінні ресурси і напрями селекційної роботи 3 ними. Сучасне птахівництво. 2004. № 10. С.1-6.
} 
Consequently, Ukrainian scientists continued breeding work with poultry including egg crosses. Thus, in 2007, turkey cross Kharkivskyi-56 was approved by the order of the Ministry of Agrarian Policy of Ukraine and the Ukrainian Academy of Agrarian Sciences under No. 780/110. And in 2016, plant line G2 of meat-and-egg chickens of the Plymutrok White breed approved by order No. 146 of April $11 .^{49}$ The organization-originator of this line recognized the State Research Station of Poultry of NAAS. The authors of this breeding achievement, which owns the largest part of participation in its creation, are Yu.V. Bondarenko, O.O. Katerynich and O.P. Zakharchenko.

In Ukraine, at the beginning of the $21^{\text {st }}$ century, an increase in poultry production was due to the significant financial resources involved in the reconstruction and technical re-equipment and expansion of production capacities on base use of high-productive poultry crosses. Favorable ground for the development of poultry farming has led to the emergence of new farms that specialize in the production of poultry eggs and meat and needed scientific support for the organization of successful business. For this purpose, the scientists of the Institute of Poultry of UAAS developed model investment projects for the creation of poultry breeding enterprises for poultry production, namely: chicken food eggs, broiler meat, ducks, turkeys and geese $\mathrm{e}^{50}$.

Thus, the leading institution that carried out scientific support of the poultry industry in Ukraine during the years of independence was Institute of Poultry of National Academy of Agrarian Sciences of Ukraine (NAAS), which several times reorganized, namely: in 2011, according to the order of the NAAS No. 297 of November 3 this institution was transformed into a scientific subdivision of the Institute of Animal Husbandry of the NAAS, and from December 2013 (the order of the NAAS No. 166 of 10.12.2013) and to date it has the status of a State Research Station for Poultry, which is subordinate to the NAAS.

However, scientists of other institutions, in particular the National University of Life and Environmental Sciences (NULES) of Ukraine, also made a significant contribution to the scientific support of the poultry

\footnotetext{
${ }^{49}$ Гадючко О., Катеринич О., Терещенко О., Рябоконь Ю. Дієтична птиця - в перспективі 2009. URL: https://propozitsiya.com/diietichna-pticya-v-perspektivi (дата звернення 25.05.2019).

50 Збірник модельних інвестиційних проектів створення птахівницьких підприємств з виробництва продукції птахівництва / За ред. Ю.О. Рябоконя. Бірки, 2005. 59 с.
} 
industry at this stage. First of all, it is necessary to note the scientific activities of the school of Academician Ildus Ibatulovych Ibatullin (the first Vice-Rector of the NULES of Ukraine). About $70 \%$ of research conducted under his direction is devoted to solving problems of optimizing poultry feeding of different types and directions of productivity and feed technology. Among the representatives of the scientific school are: M.Yu. Sychov, V.V. Otchenashko, M.Ya. Krivenok, K.Yu. Yastrebov, A.I. Chigrin, N.M. Slobodianyk, L.M. Zlamaniuk, I.I. Ilchuk, V.M. Kondratiuk, D.P. Umanets, O.V. Yatsenko, V.M. Nedashkivskyi, I.M. Balanchuk, R.V. Martyniuk, M.I. Golubev, S.V. Boiarchuk, R.M. Deineko, and others ${ }^{51}$. Doctor of Agricultural Sciences, Professor Vitalii Petrovych Borodai headed the Department of Poultry Farming in 1995-2010 and under his leadership were conducted a number of the studies on poultry farming in accordance with state scientific subjects.

Academician M.I. Sakhatskyi (former director of the Institute of Poultry of UAAS, in 1988-2003) presently works as the head of the Biology Department of NULES of Ukraine and prepares young scientists who under his direction conduct research on improving the technology of broiler chicken keeping.

It should be emphasized that the NULES of Ukraine not only provides scientific support to the development of the poultry industry, but also trains staff-specialists in the educational stages "Bachelor" and "Master".

It should also be noted that the coordination role in the field of poultry farming in Ukraine during the years of independence was also carried out by such associations as Ukrpoultryindustry and the Association "Poultry Union of Ukraine", which was established in 2003 as a result of the unification of Ukrainian industry-producers of poultry farming. This association sees its mission as creating favorable conditions for the development of the poultry industry in Ukraine.

\section{CONCLUSIONS}

Thus, in the development of poultry farming in Ukraine in the second half of the $20^{\text {th }}$ - the beginning of the $21^{\text {st }}$ centuries we identified two stages: the first covers 1951-1991, the second - 1991-2018. In the first stage, we identified periods: the first - 1951-1964, the second 1964-1971, the third - 1971-1982 and the fourth - 1982-1991.

51 Людина високого інтелекту та нестримної енергії: до70-річчя від дня народження академіка НААН Ібатулліна Ільдуса Ібатулловича / за заг. ред. С.М. Ніколаєнка. К.: Аграрна наука, 2016. 208 с. 
At the first stage, which begins in the middle of the $20^{\text {th }}$ century, poultry farming is characterized by seasonal production. Poultry farming of the public sector was mainly concentrated in the collective farms, the system of poultry keeping was extensive, using pasture for geese and turkeys and water reservoirs for waterfowl. Ukrainian scientists created a Large Gray Goose breed, a breed groups of Ukrainian ducks. Considerable attention was paid to breeding of the ducks for the meat production. M.V. Dakhnovskyi developed a method of duck growing in the water reservoirs using natural feeds. However, already in the early 60's the state farm "Yagotynskyi" was put into operation, where for the first time the breeding of the ducklings was introduced without the use of water reservoirs and at the same time they used dry feed mixes.

However, a considerable increase in poultry farming occurred after its official transfer to the industrial base in 1964. From this period, broiler production has been favored in the production of poultry meat. They keep broilers on the floor, on the deep litter, and in cage batteries. At the same time, they paid attention to the development of duck and turkey farming, where intensive methods of poultry breeding for meat were widespread. For eggs and meat production linear and hybrid poultry were increasingly used. It was created the domestic crosses of egg chickens "Birky-I" and "Birky-II" were created.

In general, scientific and methodological support of the development of poultry farming was carried out by scientists at the Ukrainian Scientific Research Institute of Poultry. Thus, in different years of the stage 1951-1991, A.U. Bykhovets, I.S. Skuratov, L.M. Belov, M.G. Kurdiukov, T.S. Len, V.I. Butovska, M.B. Dubovskyi, M.V. Dahnovskyi, M.O. Demchenko, I.Ya. Titskyi, V.V. Haskin, A.B. Baidevalatov, K.O. Bahmet, I.Yu. Bezrukava, I.M. Doroshko, E.S. Ostrovskaia, B.V. Litovchenko, V.F. Nesterenko, S.E. Brodetzka, V.F. Ivashchenko, Yu.N. Batiuzhevskyi, S.A. Vodolazhchenko, V.F. Karavashenko, Yu.M. Nasonov, V.I. Konovalov, T.Ya. Sapozhnikova, O.T. Hadiuchko, G.T. Kovalenko, V.P. Kovalenko, Yu.V. Bondarenko, I.A. Stepanenko, V.D. Lukyanova, O.D. Podstrazhnyi, V.O. Sergeiev, V.D. Sergeiev; V.I. Besulin, I.K. Reut, M.I. Sakhatskyi, O.P. Bondarenko, V.O. Breslavets, V.O. Lukyanov, A.A. Popov, L.G. Prokudina, P.M. Sliusar and others made a significant contribution to the development of poultry farming. 
During the period of independence, the poultry industry of Ukraine experienced the periods of decline (1991-1997), stabilization, and gradual recovery. The Institute of Poultry of UAAN has played an important role in the organizational and scientific provision of poultry farming. It has undergone reorganization changes and now has the status of the State Research Station of Poultry of the NAAS.

Thus, poultry breeding in Ukraine is currently the leading sector of animal husbandry and continues to develop.

The prospects for further research are the study of the achievements of some Ukrainian scientists who have made a significant contribution to the development of domestic poultry industry.

\section{SUMMARY}

The article shows the development of poultry farming in Ukraine in the second half of the $20^{\text {th }}$ - the beginning of the $21^{\text {st }}$ centuries. Author has identified two its stages: the first covers 1951-1991, the second 1991-2018. The article highlights four periods of the first stage: the first - 1951-1964, the second - 1964-1971, the third - 1971-1982, fourth - 1982-1991. Development of all directions of poultry farming was characterized, the dynamics of poultry eggs and meat production was analyzed according to certain stages and periods. It was shown that the basic scientific and methodological support of the poultry industry was assigned to the Ukrainian Scientific Research Institute of Poultry, which during the studied period undergone structural changes, and presently has the status of the State Research Station of Poultry of the National Academy of Agrarian Sciences of Ukraine. The main directions of researches of Ukrainian scientists, who made a significant contribution to the development of poultry farming, were presented. The scientific activities of researchers of the National University of Life and Environmental Sciences of Ukraine, which solves the problems of modern poultry farming in Ukraine, was covered.

\section{REFERENCES}

1. Melnyk V. Development of poultry farming of Ukraine in the period of independence. Sciences of Europe. 2019. Vol.6, № 40. P. 45-48.

2. Библиографический указатель печатных работ сотрудников Украинского научно-исследовательского института птицеводства (1930-1980) / под общ. ред. А.В. Шомина. Харьков, 1983. 102 с. 
3. Божко П. Е. Сенников А. А. Производство утиного мяса в совхозе «Яготинский». М.: Колос, 1965. 152 с.

4. Гадючко О., Катеринич О., Терещенко О., Рябоконь Ю. Дієтична птиця - в перспективі. 2009. URL: https://propozitsiya.com/ diietichna-pticya-v-perspektivi (дата звернення 25.05.2019).

5. Дахновський М. В. Ефективність вирощування качок на морських і прісних водоймах. Вісник с.-г. науки. 1959. №2. С. 53-57.

6. Державна служба статистики України URL: http://ukrstat.gov.ua/ (дата звернення 25.05.2019).

7. Друковані праці співробітників Державної дослідної станції птахівництва НААН за 1981-2016 роки: [бібліографічний покажчик] / А.П. Пономарьова. Бірки, 2016. 211 с.

8. Збірник модельних інвестиційних проектів створення птахівницьких підприємств з виробництва продукції птахівництва / За ред. Ю.О. Рябоконя. Бірки, 2005. 59 с.

9. Иванов М. Ф. Сельскохозяйственное птицеводство. Харьков: Союз, 1919. $225 \mathrm{c}$.

10. Кадура М. І., Пономарьова Ж. В., Шищенко Є. П. Виробництво качиного м'яса на інтенсивній основі. К.:Урожай, 1988. 96 с.

11. Коваленко А. Развитие мясного птицеводства на Украине. Птииеводство. 1977. №8. С. 7-9.

12. Косенко Н. Ф., Сапронова Н. И., Ольховик Л. А. Методические рекомендации по использованию яичных кроссов «Борки-І» и «Борки-ІІ». Харьков, 1978. 10 с.

13. Куров Ю. А. Птахівництво на промисловій основі. Київ: Урожай, 1973. 80 с.

14. Литвинец Г. M. Старинская птицефабрика специализированное индейководческое хозяйство. Птищеводство. 1962. №3. С. 21-23.

15. Людина високого інтелекту та нестримної енергії: до 70-річчя від дня народження академіка НААН Ібатулліна Ільдуса Ібатулловича / за заг. ред. С.М. Ніколаєнка. К.: Аграрна наука, 2016. 208 с.

16. Марчик В., Бронфман Е. Бройлерная фабрика в содружестве с колхозами. Птицеводство. 1970. № 9. С. 12-13.

17. Мельник В. В. Теоретико-методологічні та науковоорганізаційні засади розвитку штучної інкубації в Українській РСР 
У 1964-1991 роках. Гілея : науковий вісник, зб. наук. праць. Київ, 2019. Вип. 145(6). С. 99-102.

18. Народне господарство Україніської РСР у 1990 році : стат. щорічник /від. за вип. В. В. Самченко. Київ: Техніка,1991. 496 с.

19. Народне господарство Української РСР у 1984 році : стат. щорічник / відп. за вип. Б. А. Сівко. Київ: Техніка, 1985. 406 с.

20. Народне господарство Української РСР в 1964 році : статистичний щорічник. Київ: ЦСУ УРСР «Статистика», 1965. 694 с.

21. Народне господарство Української РСР у 1991 році : стат. щорічник /від за вип. В.В. Самченко. Київ: Техніка,1992. 468 с.

22. Народное хозяйство Украинской ССР в 1973 году : статистический ежегодник. Киев: «Статистика», 1974. 584 с.

23. О мерах по дальнейшему увеличению производства яиц и мяса птицы на промышленной основе. Постановление Центрального Комитета КПСС и Совета Министров СССР от 26 февраля 1971 г., № 165. Свод законов СССР. Москва: Известия, 1985. Т. 7. С. 517-519.

24. Об организации производства яиц и мяса птицы на промышленной основе. Постановление Совета Министров СССР и Центрального Комитета КПСС от 3 сентября 1964 г., № 740. Свод законов СССР. Москва: Известия. 1985. Т. 7. С. 512-517.

25. Продовольственная программа СССР на период до 1990 года u меры по ее реализаџии : материалы майского Пленума ЦК КПСС 1982 г. Москва: Политиздат, 1984. 111 с.

26. Слюсар П. М. Селекція ліній курей порід корніш і плімутрок в процесі їх акліматизації. Птахівництво: міжвід. темат. наук. зб. Київ: Урожай, 1969. Вип. 8. С. 31-37.

27. Степаненко I. А., Коваленко Г. Т., Іванова Т. В., Гадючко О. Т., Ваврійчук Т. В., Луніна Л. А. Дослідне господарство «Борки»: племінні ресурси і напрями селекційної роботи 3 ними. Сучасне птахівництво. 2004. № 10. С. 1-6.

28. Український науково-дослідний інститут птахівництва / відп. ред. М.В. Дахновський. Київ: Видавництво УАСГН, 1961. 83 с.

29. Фисинин В. И. История птицеводства российского. М.: Хлебопродинформ, 2016. Т. 2. 348 с.

30. Хаскін В. В. Деякі питання взаємозвязку азотстого та енергетичного обміну в онтогенезі курей. Птахівництво: наукові пращі. К.: УАСГ, 1961. Т. 9. Вип. 1. С. 113-122. 
31. Хачирашвили Г., Шперлинг М. Укреплять технологическую дисциплину, повышать рентабельность производства. Птищеводство. 1966. № 1. С. 7-9.

32. Центральний державний архів вищих органів влади i управління України (далі ЦДВО). Ф. 27. Оп. 8 л. Спр. 35. Арк. 33.

Information about the author: Melnyk V. V., Candidate of Agricultural Sciences, Associate Professor, National University of Life and Environmental Sciences of Ukraine 15, Heroyiv Oborony St., Kyiv, Ukraine 


\section{AGRARIAN SCIENCE DEVELOPMENT TO INCREASE THE EFFICIENCY OF IMPLEMENTATION OF ORGANIC AGRICULTURE TECHNOLOGY IN UKRAINE (1990-2015)}

\section{Orekhivskyi V. D.}

\section{INTRODUCTION}

At the beginning of the XXI century intensive use of irrigation, chemistry, mechanization with its harmful effect on soil structure, scientific breeding, including the creation of genetically modified varieties of crops, allowed to reach a new level of development of the agricultural sector, which provided a solution to the food problem in Ukraine $^{1}$. At the same time, the introduction of intensive technologies increased the technogenic impact on the soil cover and caused the spread of erosion, dehumidification and agrophysical degradation of soils in one third of arable lands of Ukraine ${ }^{2}$. The negative impact of these factors of intensification on the environment has developed the formation of new approaches to agricultural management, which are embodied in the introduction of organic technologies ${ }^{3}$. It became urgent to use rational land use in different soil and climatic zones of Ukraine, which was based on scientific technologies of organic agriculture and provided for the increase of soil fertility, production of ecologically clean production and restoration of the natural state of the environment in the country ${ }^{4}$.

Theoretical, methodological and practical foundations of organic farming technology were based on the use of rational structure of acreage and specialized crop rotation with alternation of different biological groups of crops, the use of economical soil cultivation, the introduction of scientifically grounded norms of organic fertilizers, the use of good

\footnotetext{
${ }^{1}$ Бойко П. І. Біологічна та екологічна роль сівозмін у землеробстві. Київ : Знання, 1990. 48 с.

2 Коваленко Н. П. Екологічно збалансовані сівозміни в системі альтернативного землеробства: історичні аспекти. Агроекологічний журнал. 2012. № 4. С. 95-99.

3 Коваленко Н. П. Наукові основи становлення та розвитку землеробства в Україні. Вісник аграрної науки. 2017. Спеціальний випуск (травень). С. 60-66.

${ }^{4}$ Бойко П. І., Коваленко Н. П. Проблеми екологічно врівноважених сівозмін. Вісник аграрної науки. Київ. 2003. № 8. С. 9-13.
} 
fertilizers, mulching and biohumus ${ }^{5}$. Important was the creation of varieties and hybrids with high environmental adaptability, the use of biological products for the protection of plants from weeds, diseases and pests, the introduction of environmentally friendly agro-technical and biological measures in the cultivation of crops $^{6}$. Their use contributed to the optimal cultivation of crops, as it was aimed at curbing the development of harmful organisms and did not require the use of poisonous substances ${ }^{7}$.

\section{The Role of Agrarian Science in Improving the Efficiency of Organic Technologies in Ukraine in the 1990s}

The adoption of the resolution of the Council of Ministers of the USSR No. 279 «On Establishment of the Ukrainian Academy of Agrarian Sciences» had a positive impact on the development of agrarian science in Ukraine. The above-mentioned scientific and methodological and coordination center for the development of agrarian science in the country was able to solve the most complex problems of agro-industrial production and to carry out basic and applied research ${ }^{8}$. With the foundation of the Ukrainian Academy of Agrarian Sciences, preconditions were created for eliminating interagency obstacles, technological completion of scientific developments, a comprehensive approach to the scientific support of all branches of the agro-industrial complex ${ }^{9}$. New for agricultural science was the program-targeted approach to the organization and implementation of scientific research ${ }^{10}$. This helped deepen the ability to plan scientific research, strengthen the link between scientific and industrial activities, and initiate the transition from predominantly departmental management of science to the management of the entire cycle of scientific and technological progress.

5 Бойко П. І., Бородань В. О., Коваленко Н. П. Екологічно збалансовані сівозміни - основа біологічного землеробства. Вісник аграрної науки. 2005. № 2. С. 9-13.

6 Коваленко Н. П. Становлення та розвиток науково-організаційних основ застосування вітчизняних сівозмін у системах землеробства (друга половина XIX - початок XXI ст.) : монографія. Київ: ТОВ «Нілан-ЛТД», 2014. 490 с.

7 Орехівський В. Д. Еволюція наукових основ органічного землеробства в Україні (друга половина XIX - початок ХХІ ст.) : монографія. Вінниця: ТОВ «Нілан-ЛТД», 2017. 550 с.

${ }^{8}$ Созінов О. О., Бусол В. О., Зубець М. В. Українська академія аграрних наук 1991-1995. Київ: Аграрна наука, 1996. 263 с.

9 Коваленко Н. П. Науково-організаційна діяльність Координаційно-методичної ради УАСГН, МСГ УРСР, ПВ ВАСГНІЛ та УААН з проблем сівозмін у системах землеробства України (1956-2010р.). Київ: ФОП Корзун Д. Ю., 2011.90 с.

10 Коваленко Н. П. Екологічно збалансовані сівозміни в системі альтернативного землеробства: історичні аспекти. Агроекологічний журнал. 2012. № 4. С. 95-99. 
The Ukrainian Academy of Agrarian Sciences introduced a new form of creative association of scientists of different fields of activity - scientific and methodological centers. Institutional bases around which scientific and methodological centers were formed were institutes of the relevant direction $^{11}$. In order to increase the efficiency of the research institutions of the NAAS network, a number of structural adjustments were made and the staff of the scientific units was improved. Separate institutions and units that were not operating effectively were eliminated. The experimental farms, which have lost their connection with science and performed exclusively production activities, have been transferred to the system of the Ministry of Agrarian Policy and Food of Ukraine.

This period was characterized by the creation of narrow-industry research institutes that solved problems for the effective development and practical implementation of organic technologies. So, in 1992 the Department of Agrotechnology was organized at the Institute of Cruciferous Cultures of NAAS, where they developed effective cultivation of rapeseed in different rotational rotations. In the same year, the Department of Agroecology was established at the Institute of Agroecology and Biotechnology of the NAAS. The main in his activity was the development and implementation of scientific bases of agrienvironmental monitoring, forecasting the ecological and economic efficiency of agricultural production, rational agricultural use in Ukraine ${ }^{12}$. In the 1990s, the reorganization of state regional agricultural research stations into complex regional centers of scientific support - institutes of agro-industrial production took place. Their activity was to improve existing ones, to develop and implement rational measures for organic farming for different soil and climatic conditions; creation and improvement of organic technologies for crop production.

In the 1990s, the research institutions of the NAAS network made the transition from the development of common complex scientific and technical programs to the narrow-sectoral ones, which facilitated the concentration of efforts of the co-executing institutions to solve particular problems that needed priority processing. In this period, economic analysis

11 Коваленко Н. П. Становлення та розвиток науково-організаційних основ застосування вітчизняних сівозмін у системах землеробства (друга половина XIX - початок XXI ст.) : монографія. Київ: ТОВ «Нілан-ЛТД», 2014. 490 с.

12 Коваленко Н. П. Становлення та розвиток науково-організаційних основ застосування вітчизняних сівозмін у системах землеробства (друга половина XIX - початок XXI ст.) : монографія. Київ: ТОВ «Нілан-ЛТД», 2014. 490 с. 
of results and mathematical processing of research data were considered as valuable components. Mathematization and operationalization of knowledge in agriculture have provided the beginning of science, which was based on objective facts and exact values ${ }^{13}$. Scientists have been collecting, processing and accumulating numerous data on biological, crop, productive, breeding, technological, statistical and other characteristics of crops $^{14}$. They have developed and implemented into production automated systems for evaluating the efficiency of cultivation of crops using organic technologies in Ukrainian agriculture. Of particular importance was the increase in productivity basic and applied researches, formation of scientific bases of development of organic agriculture in the market conditions, substantiation of priority directions of research work, delineation of tasks of innovative development of research institutions. A new approach has been the program-oriented approach to the organization and implementation of scientific research in organic farming. This contributed to the deepening of the possibility of planning scientific activities, opening new opportunities for establishing relationships between scientific and industrial activities, initiating the transition from mainly departmental management of science to the management cycle of scientific and technological progress in general.

In 1991, the Ukrainian Academy of Agrarian Sciences developed the first Republican scientific and technical program «Development of fundamental bases for providing the population with high quality food at optimal energy consumption and preserving ecological well-being» ${ }^{15}$. During 1991-1995, the Department of Agriculture of the NAAS carried out scientific and methodological guidance in the direction of «Development of theoretical bases of soil fertility reproduction and principles of modern intensive agriculture that will provide high quality production and environmental protection», where NAAS networks in different soil and climatic conditions of Ukraine. Scientists have constructed maps of soil zoning according to the indicated indicators for

${ }^{13}$ Kovalenko N. P. The evolution of application mathematical statistics methods have presented for processing of results of field experiments in agriculture in Ukraine (second half of XIX - beginning of XXI centuries). Історія науки і біографістика. 2016. № 2. URL: http://www.inb.dnsgb.com.ua/20162/en/09.pdf. (дата звернення: 30.06.2019).

14 Бойко П. І., Коваленко Н. П. Методика сучасних і перспективних досліджень у землеробстві. Вісник аграрної науки. 2008. № 2. С. 11-17. 1996. 264 c.

15 Звіт про роботу Української академії аграрних наук за 1991-1995 роки. Київ: Аграрна наука. 
the main crops. The estimation of ecological significance of their agrophysical features by three gradations is presented: optimal, permissible, inadmissible. Zoning of arable lands of Ukraine was carried out, which reflected the conditions of cultivation of basic crops by soil and physical indicators. The complex of measures for biological biology of agriculture based on the use of manure, by-products of agricultural products, siderates, local application of moderate norms of mineral fertilizers together with trace elements and calcium-containing compounds. It was determined that short rotational crop rotations with alfalfa and intermediate crops increased the fertility of irrigated lands ${ }^{16}$.

In 1991, the Ukrainian Academy of Agrarian Sciences, jointly with the State Agricultural Committee of Ukraine, developed the first Republican targeted comprehensive scientific and technical program «Food-95». During 1991-1995, the Department of Agriculture of the NAAS carried out scientific and methodological guidance on the project «Soil Fertility», where the research work was performed by the research institutions of the NAAS system in different soil and climatic conditions of Ukraine. Scientists have carried out preliminary normalization of soil fertility indicators, set optimal, acceptable and unfavorable parameters for growth and development of leading $\operatorname{crops}^{17}$. The ecologically safe standards of application of non-litter manure and products of its processing, ways of using by-products of crop production, sapropel, vermiculite and other raw materials of the country, which ensured an increase in the use of organic fertilizers ${ }^{18}$. Scientists have developed the scientific basics of landscape agriculture, worked out basic models of soilprotective contour-reclamation systems of agriculture. Their development ensured the prevention of soil erosion and increased the productivity of eroded lands ${ }^{19}$.

Scientists have worked out a system of measures to increase the flow of biological nitrogen into the soil through the use of local waste, increase the production of compost, the use of siderates, microbiological preparations, the expansion of crops of legumes, especially perennial

\footnotetext{
${ }^{16}$ Бойко П. І., Коваленко Н. П. Сівозміни з короткою ротацією. Пропозиція. 1998. № 2. С. 16-17.

17 Звіт про роботу Української академії аграрних наук за 1991-1995 роки. Київ: Аграрна наука. 1996. $264 \mathrm{c}$.

18 Орехівський В. Д. Еволюція наукових основ органічного землеробства в Україні (друга половина XIX - початок XXI ст.) : монографія. Вінниця: ТОВ «Нілан-ЛТД», 2017. 550 с.

19 Бойко П. І., Коваленко Н. П. Проблеми екологічно врівноважених сівозмін. Вісник аграрної науки. Київ. 2003. № 8. С. 9-13.
} 
grasses. The production of technology of application of unconventional ameliorants, which improved the agro-technical properties of podzolic soils, was proposed, increased their productivity by $30-40 \%$, reduced the absorption of radionuclides by plants in the territories contaminated by the emissions of the Chornobyl nuclear power plant ${ }^{20}$. Scientists have worked out zonal soil-protective resource-saving systems of soil cultivation in crop rotation of different specialization on the basis of a modern complex of soil-cultivating machines and tools. A resourcesaving fertilizer system has been proposed to provide planned yields while reducing mineral fertilizer consumption by $15-30 \%$ due to the widespread use of organic residues. In particular, straw, stems, siderates, provided that the number of nutrients in the soil and the biological characteristics of the crops are taken into account.

During 1996-2000, the Department of Agriculture, Reclamation and Agro-ecology of the NAAS provided scientific and methodological guidance on the scientific and technical program «To develop zonal systems of renewable agriculture for different forms of production organization». The scientists worked out the scientific bases and models of zonal conservation systems of agriculture, which took into account the socio-economic and soil-climatic conditions as much as possible, corresponded to the newest land relations at that time and provided an increase of productivity of crops by $25-30 \%$ and ecological stability ${ }^{21}$. The basis of models of systems of agriculture became the optimal structure of acreage and crop rotation, which provided a scientifically sound reduction of plowed land and increase of natural biocenoses and contributed to the restoration of nature conservation functions of agroecosystems. For the cultivation of environmentally friendly crop production, scientists have developed regulations for the use in organic agriculture of traditional and non-traditional types of fertilizers, and worked out a system of measures to optimize plant nutrition. According to the scientific and technical program «To develop the scientific basis for the creation of modern reclamation systems, technological and technical measures to improve the productivity of reclaimed lands, improve their ecological status and rational use of

20 Коваленко Н. П. Становлення та розвиток науково-організаційних основ застосування вітчизняних сівозмін у системах землеробства (друга половина XIX - початок XXI ст.) : монографія. Київ: ТОВ «Нілан-ЛТД», 2014. 490 с.

21 Звіт про діяльність Української академії аграрних наук за 1996-2000 роки та 2000 рік. Київ: Аграрна наука. 2001. 352 с. 
water resources» developed an improved system of agriculture on irrigated lands, which included the structure of sowing systems and ration crop rotation, tillage, fertilizers; energy saving technologies of growing crops on irrigated lands, recommendations on the directions of use of irrigated lands, including those that have not been irrigated temporarily, as well as withdrawn from crop rotation and flooded ${ }^{22}$.

Researchers have developed resource-saving and energy-saving systems of land use, by means of which the optimal use of the natural resource potential of agricultural landscapes is made under the conditions of limited resource provision ${ }^{23}$. Their theoretical basis was the results of studies of the bioenergy balance of agroecosystems with different levels of biologicalization of technological processes and taking into account the ecological and energy status of soils, features of modern agro-technologies. Scientists have developed the technology of integrated use of microbiological preparations, growth regulators and trace elements, the use of which has ensured the increase of grain yields by 3-17\%. The efficiency of non-traditional means of chemicalisation, which facilitated the use of local raw materials and provided environmental friendliness of agricultural technologies, was established.

Effective resource-saving biological models of grain cultivation technologies have been developed. They provided for the complete or partial elimination of the means of chemicalisation and the use of the mineral fertilizer aftereffect crop rotation and use of by-products of agricultural precursors ${ }^{24}$.

\section{Development of Agrarian Science for the Improvement of Organic Farming in Ukraine in the 2000s}

During 2001-2005, the Department of Agriculture, Reclamation and Agro-ecology of the NAAS, which was granted the status of National in 2010, carried out scientific and methodological guidance on the scientific and technical program «To develop zonal farming systems that will ensure the rational use of agricultural land, extended reproduction and cultivation and protecting them from erosion, increasing productivity and resistance to

\footnotetext{
22 Орехівський В. Д. Еволюція наукових основ органічного землеробства в Україні (друга половина XIX - початок XXI ст.) : монографія. Вінниця: ТОВ «Нілан-ЛТД», 2017. 550 с.

23 Звіт про роботу Української академії аграрних наук за 1991-1995 роки. Київ: Аграрна наука. 1996. 264 c.

24 Орехівський В. Д. Еволюція наукових основ органічного землеробства в Україні (друга половина XIX - початок XXI ст.) : монографія. Вінниця: ТОВ «Нілан-ЛТД», 2017. 550 с.
} 
agrocenoses». Scientists of the research institutions of the NAAS network have developed the scientific bases for stabilization of land use and the system of rational use and protection of land for different soil and climatic conditions of Ukraine. They took into account the different degree of interaction between natural and anthropogenic factors, especially in erosion-hazardous agricultural landscapes, based on contour-landscaping organization of land use and land tenure ${ }^{25}$.

It was important to optimize the structure of agricultural land by removing from the intensive use of eroded slopes and other low-productive lands, bringing the share of ecologically sustainable biocenoses up to $45-50 \%$ in the agricultural landscaping structure. Theoretical foundations and practical recommendations for the rational use of a wide range of agroindustrial complex chemistry agents have been developed, including organic and mineral, organo-mineral bioactive fertilizers, plant by-products and siderates, biologicals, growth promoters and trace elements. influence on actual and potential fertility of the main soil variations on the state of the environment ${ }^{26}$.

A differentiated system of agro-measures for management of soil fertility and organo-mineral nutrition of crops in ecologically clean agrophones was developed according to the scientific and technical program «Develop technologies for soil conservation and rational use and their fertility». It included: selective application of soil-free tillage, joint local application of organic-mineral fertilizers, lime, trace elements, manure and by-products ${ }^{27}$. Methodological bases of organic, organomineral fertilizers, plant growth stimulants on the basis of organic waste were worked out; technology of obtaining a mixture for reclamation with fertilizer effect on the basis of waste of the sugar processing industry, animal husbandry, production of superphosphates.

During the implementation of the scientific-technical program «Agroecological monitoring and modeling of sustainable agro-landscapes and agroecosystems» the Concept of balanced development of agroecosystems in Ukraine for the period up to 2025 was developed ${ }^{28}$. Scientists have

\footnotetext{
25 Звіт про діяльність Української академії аграрних наук за 2001-2005 роки та 2005 рік. Київ: Аграрна наука, 2006. 544 с.

26 Коваленко Н. П. Наукові основи становлення та розвитку землеробства в Україні. Вісник аграрної науки. 2017. Спеціальний випуск (травень). С. 60-66.

27 Орехівський В. Д. Еволюція наукових основ органічного землеробства в Україні (друга половина XIX - початок XXI ст.) : монографія. Вінниця: ТОВ «Нілан-ЛТД», 2017. 550 с.

28 Звіт про діяльність Української академії аграрних наук за 2001-2005 роки та 2005 рік. Київ: Аграрна наука, 2006. 544 с.
} 
improved the technology of complex application of biological preparations and poly-mineral fertilizers for various crops in different soil and climatic conditions of Ukraine.

During 2001-2005, the research institutions implemented the State Scientific and Technical Program «Industrial Biotechnologies for Agroindustrial Complex», during 2006-2010 - «Agrobiopromysystem». Scientists have developed a draft National Strategy for the Greening of Agricultural Production on the Basis of Integrated Agricultural Biologization. Reconstruction has been completed laboratories for the production of biological plant protection products and quality control of pesticides and crop production ${ }^{29}$.

During 2006-2010, the Department of Agriculture, Reclamation and Agro-ecology of the National Academy of Sciences of Ukraine carried out scientific and methodological guidance on the scientific and technical program «To develop systems for assessing the current state, protection and efficient use of soils using geoinformation technologies». Scientists have determined the scientific and applied bases, directions of protection of rational use of irrigated and irrigated lands of Ukraine ${ }^{30}$. The modern complex of regionally oriented measures for protection of soil from water and wind erosion is offered, taking into account the latest achievements of science and technology. Technologies of creation and application of liquid and solid organic and complex bioactive organo-mineral fertilizers with attraction of local raw materials according to the improved recipe have been worked out. This approach has ensured the expansion of the functional capabilities of the components of organo-mineral fertilizers, a decrease of $10-15 \%$ of unproductive nutrient losses, an increase of $20-25 \%$ of the efficiency of agricultural production.

According to the scientific and technical program «To develop scientific bases of agriculture, adapted to the natural environment and market conditions of management», scientists have worked out the system of agriculture on ecological-landscape basis for different soil and climatic conditions of Ukraine with different level of intensity and resource supply. The systems of agriculture for stabilization of land use and structure of

29 Коваленко Н. П. Становлення та розвиток науково-організаційних основ застосування вітчизняних сівозмін у системах землеробства (друга половина XIX - початок XXI ст.) : монографія. Київ: ТОВ «Нілан-ЛТД», 2014. 490 с.

30 Звіт про діяльність Національної академії аграрних наук України за 2006-2010 роки та 2010 рік. Київ: Аграрна наука, 2011. 422 с. 
natural complexes have been improved. The soil-protective contourreclamation system of agriculture, regional models of optimization of the structure of land use of agricultural enterprises of Ukraine have been developed. The methodology of monitoring of eroded lands and the model of territorial structure have been worked out agro-landscapes on ecological-landscape principles ${ }^{31}$. Peculiarities of crop placement in short rotation crop rotations based on determination of biological interaction of crops based on their compatibility, role and evaluation of precursors, norms of crop rotation in crop rotation, phytosanitary status and soil toxicity are determined. The economic efficiency of combining in the system of fertilization of bedding manure and mineral fertilizers in moderate norms with involvement in biological circulation of by-products of crop and siderate is established. The influence of fertilizers on the functioning of microbial coenoses is determined, the efficiency of inoculation of cereal seeds with a complex of microorganisms is proved.

According to the scientific-technical program «Scientific and practical substantiation of sustainable development of agroecosystems of Ukraine»» scientific and methodological aspects of creation of multifunctional microbial preparations for ecologically-safe integrated systems of protection and fertilization of plants have been developed. Scientists have searched for active strains of microorganisms with agronomically useful properties, and selected the optimal technological parameters for the cultivation of microorganisms. Their influence on the ecological and biological condition of the soil and the quality of the products have been determined $^{32}$.

During 2011-2015, the Department of Agriculture, Reclamation and Mechanization of the NAAS provided scientific and methodological guidance under the program «Scientific Basics of Rational Use, Protection and Quality Management of Soils for Sustainable Fertility». Scientists have developed the scientific foundations of landscape adaptation of irrigated, irrigated and saline lands. Quantitative and qualitative parameters of a set of adaptive measures have been established, taking into account the ecological, agronomic and economic and economic conditions of the respective arrays, fields and their areas. Scientists have proposed a method

31 Орехівський В. Д. Еволюція наукових основ органічного землеробства в Україні (друга половина XIX - початок XXI ст.) : монографія. Вінниця: ТОВ «Нілан-ЛТД», 2017. 550 с.

32 Звіт про діяльність Національної академії аграрних наук України за 2006-2010 роки та 2010 рік. Київ: Аграрна наука, 2011. 422 с. 
of complex automated evaluation and minimization of erosion risk in modern agricultural landscapes, developed a methodology for stabilizing soil erosion resistance, created a database of modern crop rotation structure with the analysis of their effect on the erosion parameters of soil agrophysical properties by elements of agricultural landscapes ${ }^{33}$.

According to the program «To develop the scientific basis for the development of agriculture in the stabilization of land use and the structure of natural lands, the use of technologies for competitive production of crop production, conservation and reproduction of soil fertility» scientists have established a significant deterioration of the physical and chemical properties of soil in terms of prolonged perennial peregrination. As the removal of gray loamy loamy soil from intensive use led to the gradual depletion of the soil absorption complex with calcium and magnesium compounds, resulting in increased potential and exchange acidity ${ }^{34}$. It was determined that the best results of reproduction of multi-species permanent natural herbs with high homeostatic self-renewal were provided when spontaneous reproduction was combined with the starting sowing of legumes from three to four ecologically adapted to the local ecological conditions with the addition of different herbs.

Scientists have justified that in short-rotation crop rotations, zero tillage compared to the traditional one provided higher reserves of productive moisture in a meter layer of soil, which amounted to $104,9-108,9 \mathrm{~mm}$ in soybean crops, and 94,1-104,2 $\mathrm{mm}$ in corn. The ratio of the mineralization intensity of humic and fulvic acids with the intensity of by-product humification, which was wrapped in a $0-20 \mathrm{~cm}$ black soil layer, was reflected in the non-polishing treatment, which affected the increase in the total humus stock and changes in its group and fractional composition $^{35}$. The use of organic fertilizers helped to improve the biological regime of the soil, which led to the formation of bacterial diversity and increase its species forms. It has been found that biologized fertilizer systems have led to an improvement in the photosynthetic and chlorophyll potential of plants.

\footnotetext{
33 Звіт про діяльність Національної академії аграрних наук України за 2011-2015 роки та 2015 рік. Київ: Аграрна наука, 2016. 520 с.

34 Орехівський В. Д. Еволюція наукових основ органічного землеробства в Україні (друга половина XIX - початок XXI ст.) : монографія. Вінниця: ТОВ «Нілан-ЛТД», 2017. 550 с.

35 Коваленко Н. П. Становлення та розвиток науково-організаційних основ застосування вітчизняних сівозмін у системах землеробства (друга половина XIX - початок XXI ст.) : монографія. Київ: ТОВ «Нілан-ЛТД», 2014. 490 с.
} 
According to the subprogramme «To develop theoretical bases and models of functioning of agro-systems and means of technological management of processes of self-renewal in the steppe zone agriculture», it was found that the use of microbial preparations provided an increase in the efficiency of soybean cultivation in grain-steam-cultivated and grainsowing crop rotations. When performing the subroutine «Theoretical Foundations and Ecologically Safe Methods of Regulation of Weed of Field Crops in Modern Agriculture», it was determined that the greatest competitiveness against weeds was obtained when growing winter wheat after black steam ${ }^{36}$. A lack of ability to withstand weeds in sugar beet, especially in the initial growth stages, was detected. Therefore, adhering to the elements of the technology of cultivation of this crop provided better clearing of the field of weeds.

The program «Ecological Safety of Agroindustrial Production» developed a method of ecological evaluation of technologies for growing basic crops, which ensured consideration of agrochemical, phytosanitary, ecotoxicological, sanitary-hygienic and other characteristics and avoiding negative impacts on the environment ${ }^{37}$. Scientists have substantiated the principles of determining ecological coefficients to evaluate the feasibility of fertilizing crops for the use of nitrogen fixation and nitrous oxide emissions. They have developed a method for biological disposal of pathogenic soil microflora, which consisted of pre-sowing treatment with spore bacteria and provided prolonged plant protection against disease. Scientists have proposed a method of accelerating the decomposition of postharvest residues, based on the joint use of a complex of microorganisms. Obtained polyclonal antiviral sera for up to two viruses - cucumber mosaic virus and spotting virus of tomatoes. According to the program «Scientific bases of rational water use and land reclamation in the conditions of socio-economic transformation of rural territories» scientists have substantiated the components of the technology of creating long-lasting hay-pasture grassland for use on drained podzolic silt and soils ${ }^{38}$.

\footnotetext{
36 Орехівський В. Д. Еволюція наукових основ органічного землеробства в Україні (друга половина XIX - початок XXI ст.) : монографія. Вінниця: ТОВ «Нілан-ЛТД», 2017. 550 с.

37 Коваленко Н. П. Становлення та розвиток науково-організаційних основ застосування вітчизняних сівозмін у системах землеробства (друга половина XIX - початок XXI ст.) : монографія. Київ: ТОВ «Нілан-ЛТД», 2014. 490 с.

38 Орехівський В. Д. Еволюція наукових основ органічного землеробства в Україні (друга половина XIX - початок XXI ст.) : монографія. Вінниця: ТОВ «Нілан-ЛТД», 2017. 550 с.
} 
Important was the implementation of the program «Scientific basis for the development of organic production of agricultural products and the mechanisms of its functioning in Ukraine». According to the subprogramme «Scientific bases of forming of zones of organic production of agricultural goods are taking into account ground-climatic terms» placing and optimal areas of new economies is certain scientists from the conduct of organic agriculture, their specialization in accordance with the soil and climatic conditions of the forest-steppe ${ }^{39}$. The main limiting factors that hindered the development of organic production were identified, the optimal area of organic farming was established, which amounted to 800-1000 ha in the presence of livestock, 1000 ha - for grain and beet farms. The zoning of the forest-steppe was developed according to the suitability for organic farming, which characterized the soilecological features and the resource potential of the lands for growing basic crops. Scientists have worked out the methodological aspects of obtaining organic fertilizers from by-products of crop and waste animal husbandry, which was to improve the methods of processing organic matter and their composition. Enhancement of fertilizer functionality was due to the addition of substances with expanded active surface, enzymatic and microbiological preparations at various stages of composting.

The implementation of the sub-programme «Innovative Technologies for Competitive Organic Production of Crop Production» with the application of an organic fertilizer system in short rotational rotations resulted in a reduction of moisture costs for the formation of a dry matter unit of the crop. Optimization basic models of reproduction of fertility of washed soils have been worked out, the prerequisites for development of introduction of organic production of agricultural products in Ukraine have been analyzed, the main scientific and methodological approaches to their solution have been determined. It was found that the main measures for increasing soil fertility under organic farming conditions were liming and application of organic fertilizers. It has been found that the use of an organic fertilizer system and microbial preparations in short rotational rotations promoted the destruction of bacterial, fungal and viral diseases of crops $^{40}$. Scientists have developed a stable green conveyor from scattered

\footnotetext{
39 Звіт про діяльність Національної академії аграрних наук України за 2011-2015 роки та 2015 рік. Київ: Аграрна наука, 2016. 520 с.

40 Коваленко Н. П. Становлення та розвиток науково-організаційних основ застосування вітчизняних сівозмін у системах землеробства (друга половина XIX - початок XXI ст.) : монографія. Київ: ТОВ «Нілан-ЛТД», 2014. 490 с.
} 
grass stands on drained lands without mineral fertilizers and with a fourfold mowing, which helped to obtain 5,0-5,5 t/ha of absolutely dry weight.

It has been determined that when engaging enterprises, the oils of fat and malt production in organic agriculture, their waste can be used as fertilizer in agrocenoses, provided the annual quality control of fertilizers with the determination of environmentally sound standards for their application $^{41}$. The ecological substantiation of production waste norms is developed, which is recommended to be used in agroland landscapes for ground fertilizer, on the content of nutrients and pollutants in substrates. The use of litter manure, straw, and biomass of post-harvest siderates is justified for the efficient cultivation of crops in organic farming. The highest efficiency of the use of alternative sources of organic matter and microbiological preparations as a result of the combination of wrapping straw wheat-lupine mixture treated with bio-degrader.

According to the sub-program «System of Quality Assessment of Organic Production», elements of the regulatory and methodological support for the procedure of controlling the production of organic products based on the Law of Ukraine «On Production and Circulation of Organic Agricultural Products and Raw Materials» and international requirements have been developed. Scientific and methodological approaches to the standardization of weed, disease and pest management methods for organic farming have been identified. The list of biological preparations for further certification is proposed for use in plant protection technologies against diseases and pests. Biologicals were divided into 2 groups: direct action biopesticides and indirect action-drugs that improved plant growth. Important principles have been established for the application of elements of organic farming technology. In particular, determining the action to prevent the development of erosion processes, maintain a satisfactory structural condition, regulate the regime of organic matter and mineral elements of the soil, reduce weediness of crops, regulate the phytosanitary state of soil and water balance of agrocenoses ${ }^{42}$.

During the implementation of the subprogram «Scientific bases of formation and functioning of the organic production market» elements of organic production technology are identified: observance of crop rotations,

\footnotetext{
41 Звіт про діяльність Національної академії аграрних наук України за 2011-2015 роки та 2015 рік. Київ: Аграрна наука, 2016. 520 с.

42 Орехівський В. Д. Еволюція наукових основ органічного землеробства в Україні (друга половина XIX - початок XXI ст.) : монографія. Вінниця: ТОВ «Нілан-ЛТД», 2017. 550 с.
} 
application of organic fertilizers, siderates, mulching, destructors, organic remedies, growth regulators ${ }^{43}$. Organic fertilizer systems were established, which were based on the following components: manure application, use of by-products of crop production for fertilizer except for the part that was directed to the needs of animal husbandry; intensive sideration; pre-sowing seed treatment of all major and intermediate crops with biological microbial preparations ${ }^{44}$. According to the program «Scientific and engineering-technological bases of creation of ecologically safe industrial biotechnologies and equipment for production and use in agrobiocenoses of biological plant protection products» the structure of entomological production quality management system was determined and the method of calculations of entomological production processes was developed ${ }^{45}$. Conceptual approaches to the formation of organic farming system based on the application of biological plant protection are proposed.

\section{CONCLUSIONS}

Thus, analyzing the trends of agricultural science in the 1990s showed that with the organization of the Ukrainian Academy of Agrarian Sciences, the preconditions were created to increase the effectiveness of sectoral research and increase the efficiency of the introduction of organic technologies in different soil and climatic conditions of Ukraine. Scientific and organizational activities of the National Academy of Agrarian Sciences of Ukraine in the 2000s in the direction of the development of organic agriculture ensured the expansion of the network of sectoral research institutions, their uniform geographical location and coverage of different areas of research. Scientists have developed effective technologies of organic farming, the practical implementation of which in different soil and climatic conditions of Ukraine has ensured the increase of soil fertility, obtaining quality agricultural products and preserving the environment.

It can be concluded that the development and implementation of energy-saving and resource-saving technologies, which ensured a

\footnotetext{
43 Звіт про діяльність Національної академії аграрних наук України за 2011-2015 роки та 2015 рік. Київ: Аграрна наука, 2016. 520 с.

44 Бойко П. І., Бородань В. О., Коваленко Н. П. Екологічно збалансовані сівозміни - основа біологічного землеробства. Вісник аграрної науки. 2005. № 2. С. 9-13.

45 Коваленко Н. П. Становлення та розвиток науково-організаційних основ застосування вітчизняних сівозмін у системах землеробства (друга половина XIX - початок XXI ст.) : монографія. Київ: ТОВ «Нілан-ЛТД», 2014. 490 с.
} 
significant increase in the production of quality products and increased profitability of the crop industry, became especially relevant. Scientists of the research institutions have developed and improved scientifically grounded crop rotations with the cultivation of legumes and side crops, perennial legumes and their mixtures, post-harvest and post-harvest crops, using by-products. Effective use of rational soil cultivation, organomineral fertilizers, integrated weed, pest and disease control systems has been proved.

Established that one of the directions of successful plant protection in organic farming was the creation of environmentally safe industrial biotechnologies for the production and use in agrobiocenoses of biological plant protection products. They were introduced along with agrotechnical and organizational ecologically safe measures of plant protection: scientifically based alternation of different crop groups in rotation; optimal timing and methods of soil cultivation and fertilization, sowing and harvesting; seed cleaning and sorting; spatial isolation of territories, etc.

\section{SUMMARY}

It was found out that during the 1990s - 2000s the development of the agricultural sector of Ukraine was ensured by the introduction of effective technologies for growing crops under different soil and climatic conditions of Ukraine. They were based on the use of a scientifically sound structure of acreage and specialized crop rotations with effective alternation of different biological groups of crops. Important was the use of organic fertilizers and soil conservation, as well as environmentally friendly measures. With their introduction in Ukraine important practical tasks were solved: increase of soil fertility level, production of quality agricultural products and preservation of the environment.

To this end, the article, based on the system-historical approach, identifies the directions of development of agrarian science for increasing the introduction of organic farming technologies in different soil and climatic conditions of Ukraine. In particular, application of scientifically grounded structure of acreage and specialized crop rotations with alternation of different biological groups of crops, cultivation of leguminous and sider crops for green fertilizer, perennial legumes and their mixtures, post-harvest and post-crop crops, use of by-products. Important was the elaboration of systems of economical soil cultivation, introduction 
of scientifically grounded standards of organic fertilizers, use of microorganisms, biohumus, creation of varieties and hybrids with high ecological adaptability, biological preparations for protection of plants from weeds, diseases and pests. It was found out that scientifically grounded technologies of organic agriculture, developed by scientists of research institutions of the network of the National Academy of Agrarian Sciences of Ukraine, were effectively implemented in the farms of different soil and climatic conditions, which ensured the increase of soil fertility, obtaining of high quality agricultural production Of Ukraine.

\section{REFERENCES}

1. Kovalenko N. P. The evolution of application mathematical statistics methods have presented for processing of results of field experiments in agriculture in Ukraine (second half of XIX - beginning of XXI centuries). Історія науки $i$ біографістика. 2016. № 2. URL: http://www.inb.dnsgb.com.ua/2016-2/en/09.pdf. (дата звернення: 30.06.2019).

2. Бойко П. І. Біологічна та екологічна роль сівозмін у землеробстві. Київ : Знання, 1990. 48 с.

3. Бойко П. І., Бородань В. О., Коваленко Н. П. Екологічно збалансовані сівозміни - основа біологічного землеробства. Вісник аграрної науки. 2005. № 2. С. 9-13.

4. Бойко П. І., Коваленко Н. П. Методика сучасних i перспективних досліджень у землеробстві. Вісник аграрної науки. 2008. № 2. C. 11-17.

5. Бойко П. І., Коваленко Н. П. Проблеми екологічно врівноважених сівозмін. Вісник аграрної науки. 2003. № 8. С. 9-13.

6. Бойко П. І., Коваленко Н. П. Сівозміни з короткою ротацією. Пропозиція. 1998. № 2. С. 16-17.

7. Звіт про діяльність Національної академії аграрних наук України за 2006-2010 роки та 2010 рік. Київ: Аграрна наука, 2011. 422 c.

8. Звіт про діяльність Національної академії аграрних наук України за 2011-2015 роки та 2015 рік. Київ: Аграрна наука, 2016. $520 \mathrm{c}$.

9. Звіт про діяльність Української академії аграрних наук за 1996-2000 роки та 2000 рік. Київ: Аграрна наука. 2001. 352 с. 
10. Звіт про діяльність Української академії аграрних наук за 2001-2005 роки та 2005 рік. Київ: Аграрна наука, 2006. 544 с.

11.Звіт про роботу Української академії аграрних наук за 1991-1995 роки. Київ: Аграрна наука. 1996. 264 с.

12. Коваленко Н. П. Екологічно збалансовані сівозміни в системі альтернативного землеробства: історичні аспекти. Агроекологічний журнал. 2012. № 4. С. 95-99.

13. Коваленко Н. П. Наукові основи становлення та розвитку землеробства в Україні. Вісник аграрної науки. 2017. Спеціальний випуск (травень). С. 60-66.

14. Коваленко Н. П. Науково-організаційна діяльність Координаційно-методичної ради УАСГН, МСГ УРСР, ПВ ВАСГНІЛ та УААН з проблем сівозмін у системах землеробства України (1956-2010 р.). Київ: ФОП Корзун Д. Ю., 2011. 90 с.

15. Коваленко Н. П. Становлення та розвиток науковоорганізаційних основ застосування вітчизняних сівозмін у системах землеробства (друга половина XIX - початок XXI ст.) : монографія. Київ: ТОВ «Нілан-ЛТД», 2014. 490 с.

16. Орехівський В. Д. Еволюція наукових основ органічного землеробства в Україні (друга половина XIX - початок XXI ст.) : монографія. Вінниця: ТОВ «Нілан-ЛТД», 2017. 550 с.

17. Созінов О. О., Бусол В. О., Зубець М. В. Українська академія аграрних наук 1991-1995. Київ: Аграрна наука, 1996. 263 с.

\section{Information about the author: Orekhivskyi V. D., \\ Doctor of Historical Sciences,}

Director of Odessa state agricultural experimental station, National Academy of Agrarian Sciences of Ukraine 24, Mayatska road St., Khlibodarske Smt., Belyaivskyi district, Odessa region, 67667, Ukraine 


\section{CENTRALIZATION OF AGRICULTURAL RESEARCH CASE IN UKRAINE IN THE FIELD OF POLITICAL AND SOCIAL-ECONOMIC CONDITIONS (20-30th OF XX CENTURY)}

\section{Shchebetyuk N. B.}

\section{INTRODUCTION}

The modern challenges of the existence of the Ukrainian statehood and the realities of the formation of a civil society actualize the need to the recovery of historical memory, creating a national history. The history of domestic science is as a part of the latter that synthesizes the analysis of the ways of its development and movement features combined knowledge of the history of the country, producing new knowledge about the functionality research area. Of particular importance is the study and rethinking of the historical advancement of the agrarian science of Ukraine, which evolved in the face of radical political, socio-economic changes. The research moreover, rethinking of historical advancement of agrarian science of Ukraine that evolved on background radical political and socio-economic changes take on the special significance. The substantial transformations took place from the end of 20-30th of past century, when the search of forms and methods of development of branch research has developed. Its coordinating component acquired forms of institutionalization, transformed into a form of academic activities with defined priorities.

The creation of national coordination centers for agricultural research case in the 20th of the XX century is devoted to a number of publications. Among them are the generalizing works of the Prof. Victor A. Vergunov ${ }^{1}$ and the collections of documents and materials prepared under his direction ${ }^{2}$. However, further research of certain stages of the evolutionary

1 Вергунов В. А. Академізація вітчизняної сільськогосподарської дослідної справи: істориконауковий аналіз. Нариси з історії природознавства $і$ техніки : зб. наук. пр. / Центр досліджень наук.техн. потенціалу та історії науки ім. Г. М. Доброва НАНУ, Укр. тов-во істориків науки. Київ: Фенікс, 2005. Вип. 45. С. 167-182; Вергунов В. А. Науково-організаційні засади становлення та діяльності Національної академії аграрних наук України (до 80-річчя заснування НААН) : наук. доп.; НААН, ДНСГБ. Київ: Аграр. наука, 2012. 28 с.

2 Всеукраїнська Академія Сільськогосподарських Наук (1931-1935 рр.) : зб. док. і матеріалів. До 75-річчя створення Укр. акад. аграр. наук / УААН, ДНСГБ ; уклад. В. А. Вергунов та ін. Київ, 2006. 
path of the Ukrainian agrarian science and, in particular, the period of the first attempt of its academy form, are not lost relevance. The purpose of this study was to reveal the peculiarities of the process of forming the coordinating bodies for conducting agricultural research case on Ukrainian territories in the 20-30th years of the XX century in the field of political and social-economic conditions. Fundamental in the work are the principles of objectivity, historicism, and interdependence of historical and logical, systemic, etc. The researcher also applied a system of complementary methods (proper historical, general, primary sources, archival, etc.).

\section{Socio-political, Economic and Scientific-organizational Factors of Creation of Scientific Support of Agriculture}

It is doubtless awareness that deeply meaningful patterns and programs of balanced reforms are necessary for the transformation of democratic processes. Their component is historical experience that requires careful study and impartial analysis. While the reforms process in the 20-30th of the twentieth century became the personification of the tragic history of Ukrainian state and the agricultural sector in particular. According to British historian Norman Davis, the largest experiment in the history of planned modernization took place, starting in 1929, in the Soviet Union. It was such a radical and ruthless because many experts argue later, it was, not the events in 1917, is a genuine Russian revolution ${ }^{3}$.

The third decade of the twentieth century reflected a continuation of the formation of the Bolshevik doctrine of socialism with distinctive features: one-party political system, state ownership of the means of production and the dictatorship of the party-state nomenclature. The laying of the foundations of a totalitarian regime took place through repressions that differed in their methods and forms and had a comprehensive scope. In the late 20's the Soviet Union was on the verge of acute crisis due to the total absence of economic reserves. The tight deployment of new construction, large-scale production plans at existing plants resulted in a shortage of metal, and subsequently other materials

\footnotetext{
311 с.; Науково-консультаційна рада Народного комісаріату земельних справ УСРР (1927-1930рр.) : зб. док. і матеріалів / НААН, ДНСГБ ; уклад. В. А. Вергунов [та ін.]. Київ, 2010. 600 с.; Сільськогосподарський науковий комітет України (1918-1927рр.) : зб. док. і матеріалів. До 75-річчя створення Укр. акад. аграр. наук / УААН, ДНСГБ ; уклад. В.А. Вергунов та ін. Київ : Аграр. наука, 2006. 526 с. C. 988 .

${ }^{3}$ Дейвіс Норман. Європа : Історія / пер. 3 англ. П. Таращук, О. Коваленко. Київ : Основи, 2002.
} 
and raw materials. Commodity hunger has grown on the consumer market. Its causes were breaking of grain procurement, non-fulfillment of export obligations, a policy of active crowding out of private capital, etc. The USSR abandoned the market, returning to command and administrative methods, and took a course on the concentration of available resources and forced the development of a large industry. The new economic policy was not a strategic line, but only a necessary step under pressure. Later, a well-known national historian, Prof. Peter P. Panchenko noted, that for the peasantry, in the end, as well as for the entire Ukrainian people, came the most brutal trial in the history of the commanding power of the totalitarian state, full of hatred and injustice ${ }^{4}$. There was a need to move from annual to long-term planning in the context of the restoration and expansion of the public sector. In 1929, the introduction of the practice of five-year plans was approved (the first in 1928-1932). This allowed the Soviet government to manage the development of economy, technology, science, education and culture in the USSR. However, none of the five-year plan was completed, despite the huge material losses and human sacrifices. During the process of fulfilling the tasks of the first five-year plan, in addition to agriculture, there were crises in transport and in the fuel industry. It made it impossible to complete it. However, the USSR built about 1500 new industrial enterprises, including 400 in Ukraine - Dnipro Hydroelectric Power Station Hydroelectric Power Station, Kharkiv Tractor Plant, etc. ${ }^{5}$

In 1931, Soviet procurements accounted for $30 \%$ of world exports of machinery and equipment, next year - almost $50 \%^{6}$. The main sources of funding were: a) transfer of funds from light and food in heavy industry; b) increased taxes from the population; c) voluntary and forced loans (1927-1929); d) the issue of paper money not backed by gold; e) Increasing export abroad of oil, timber, furs, grain and other types of raw materials; f) strengthening the state exploitation of the peasantry and the working class, many millions of prisoners of the General Directorate of Forced Labor Camps, Labor Settlements and Places of Imprisonment (shortened popular name is GULAG). In the 1930's, the GULAG has

\footnotetext{
${ }^{4}$ Панченко П. П. Сторінки історії України ХХ століття: (Українське село : поступ, сподівання, тривоги). Київ : ІСДО, 1995. С. 22.

${ }^{5}$ П'ятирічки в СРСР // Вікіпедія. Вільна енциклопедія. URL : https://uk.wikipedia.org/wiki/ П\%27ятирічки_СРСР. (дата звернення: 04.07.2014).

${ }^{6}$ Юхименко П. І. Економічна історія : навч. посіб. Київ : Вікар, 2004. С. 65.
} 
grown to such an extent that it was numbered equal to the army, and it was up to $10 \%$ of the population of the USSR in the camps. It was possible thanks to the help the main instruments of coercion and terror - All-Russian Emergency Commission on Combating Counter-Revolution and Sabotage (United State Political Administration and People's Commissariat of Internal Affairs of the USSR). An American researcher Timothy Snyder notes that free peasants turned into a slave labor force. They used in the construction of large canals, in mines and factories, which, according to Stalin's plan, had to modernize the Soviet Union ${ }^{7}$.

The mass destruction of the population was genocide as to the Ukrainian people. It is worth noting that Stalin had a certain national policy for each nation - a policy of Polish, Russian, Jewish, and Ukrainian politics. The Holodomor in Ukraine was an element of the «Ukrainian policy» of the Bolshevik Party, such as the rise and fall of «Ukrainization», repressions against the Ukrainian intelligentsia ${ }^{8}$. As M. Braichevsky noted, in 1932-1933 the repressions in Ukraine held under the call of the struggle against bourgeois nationalism and continued until 1939 with huge losses of the national genepool of Ukrainians - writers, scientists, artists and the highest party-state leadership ${ }^{9}$. They destroyed morally millions of people through coercion with the state security agencies, the public condemnation of them by «enemies of the people», false testimonies about employees, friends and even relatives. The regime demonstrated a clear idea of the psychological and physical structure of the enemies, it pointed to the rules that the Bolshevik discourse of power arguing for revealing campaigns, indicative litigation: Ukrainian National Center, Union of Liberation of Ukraine, miners' case, etc. ${ }^{10}$. Large-scale repression of the agricultural industry professionals (economists, agronomists, Commissariat officials, staff of research institutions, cooperatives) combined with the idea of collectivization.

We noted that party-soviet leadership in the field of economics solved three problems - funds, raw materials and labor resources. It found the solution - the collectivization of agriculture that could provide an increase in financial income. The XV Congress of the All-Union

\footnotetext{
7 Снайдер Тімоті. Голод у СРСР. Уривок із книги «Криваві Землі. Європа між Гітлером та Сталіном». Історична правда. URL: http://www.istpravda.com.ua/research/2011/11/25/62973 (дата звернення: 09.02.2016).

${ }^{8}$ Попович М. Сталин. С ним и без него. Зеркало недели. Украина. № 8, 1 марта 2013 г.

${ }^{9}$ Брайчевський М. Конспект історії України. Київ : Видавн.-полігр. центр «Знання», 1993. 203 с.

${ }^{10}$ Баберовскі Й. Червоний терор. Історія сталінізму / пер. з нім. Київ : К.І.С., 2007. С. 98.
} 
Communist Party (Bolsheviks) (1927) foresaw a gradual transition to cooperation, but the practice accelerated the pace and intensified the methods of pressure. The consequence of hasty collectivization was not only a sharp reduction in livestock, falling yields crops and millions of human casualties. During 1929-1938 $94 \%$ of the 26 million peasant farms in the USSR were merged into a quarter of a million collective farms that were in fact state-owned. Those who resisted - shot or deported. In order to justify all the killings, they have created a fictional image of the social enemy - the kulaks. The system killed about 15 million men, women and children. Agricultural production fell by 30 percent $^{11}$. Therefore, the card system of providing the population acted by 1936 . Nevertheless, at the same time the government created a social base for the modernization of the agrarian sector.

In the 1930's, the process of forming an economic system, built on rigid centralism and policy, was completed. Regulated not only scheduled tasks, but also resources, forms and sizes of wages and other indicators of management. Such a rigid system of planning enabled to concentrate economic resources in certain spheres of economic, scientific and social activity. As a result, already during the second five-year period (1933-1937), gross industrial output increased 2.2 times, agriculture was 1.5 times, and production costs decreased by $10.3 \%$ compared to the first five-year period $(2.3 \%)^{12}$. Stalin's program of building a military industrial state covered six interconnected elements: centralized management, accelerated industrialization, rearmament, collectivization of agriculture, ideological warfare and political terror. As Norman Davis wrote, the ambition of the ten-year program of the USSR killed the spirit, and if to take into account human life, its perniciousness surpassed any other disaster of European history, even the horror of the Second World $\mathrm{War}^{13}$. In accordance with the directives of the II session of the AllUkrainian Central Executive Committee (December 1929) in the field of agriculture for the 1929-1930, a number of tasks were envisaged. First, increase the total sown area by $10.1 \%$, including $8.3 \%$ for grain crops, and $8.6 \%$ for technical crops. Bring the area of contracting cotton to

\footnotetext{
C. 991.

${ }^{11}$ Дейвіс Норман. Свропа : Історія / пер. 3 англ. П. Таращук, О. Коваленко. Київ : Основи, 2002.

12 П'ятирічки в CPCP // Вікіпедія. Вільна енциклопедія. URL: https://uk.wikipedia.org/wiki/ П\%27ятирічки_СРСР. (дата звернення: 04.07.2014). C. 990 .

13 Дейвіс Норман. Європа : Історія / пер. 3 англ. П. Таращук, О. Коваленко. Київ : Основи, 2002.
} 
3,000 hectares, soybeans - 55,000 hectares, kenaf - 9,000 hectares. To increase the area under sugar beet by $16.6 \%$, cannabis - by $26.9 \%$, tobacco - by $70.3 \%$, grain crop yield by $15 \%$, and achieve a $26 \%$ increase in grain production by the five-year target year. Increase livestock by $14 \%$ against $1928-1929^{14}$.

The necessity to accomplish the tasks set dictated the change in the requirements for the scientific provision of the agricultural sector. It deployed a broad discussion of the best forms of functioning of research institutions and establishing certain schemes of their interaction. Famous scientists-agrarians - O. Yanata, O. Sokolovskiy, S. Kulzhinskiy, G. Makhov, V. Wiener, A. Slipanskiy and others expressed their vision of building a branch research case. In particular, the prominent agronomist and botanist O. Yanata noted, that organization in science could be achieved only in the appropriate synthesis of state initiative and leadership and initiative and amateur individual and public, the scientific workers themselves ${ }^{15}$.

In the 20's of the XX century, the Agricultural Scientific Committee of Ukraine and later the Scientific-Consultative Council of the People's Commissariat of Land Affairs of the Ukrainian SSR became the organizational coordinating forms. At that time, science was developing in higher agricultural institutions and opening the experimental agricultural chairs. They published a number of collections of scientific papers, testifying to the significant scientific achievements on various issues of the agricultural sector. However, O. Yanata noted the danger of the loss of agricultural science the achievements of previous years. He stressed that science more confined to narrow forms of agricultural experimental case without any activity, lagging far from the current pace of agricultural life. The First Congress of Soviets and the Presidium of the Central Executive Committee of the USSR on August 8, 1924 declared the founding of the All-Union Academy of Agricultural Sciences named after V.I. Lenin. Nevertheless, O. Yanata thought that the creation of the Ukrainian Academy of Agricultural Sciences would be the only organization of agricultural science in Ukraine. It was to become an integral part of the All-Union Academy of Agricultural Sciences named after V.I. Lenin. The

\footnotetext{
${ }^{14}$ Щебетюк Н.Б. Розвиток аграрної науки України наприкінці 20-х - у 30-і рр. ХХ ст. Кам'янецьПодільський, 2017. 380 с.

${ }^{15}$ Яната О. А. Час заснувати Українську академію наук сільськогосподарських. Наука та техніка. 1925. № 2. C. $45-49$. c. 45
} 
scientist believed that only the high academic credibility of the Academy would be able to unite the scattered scientific forces and direct them to rational solution of existing problems of agricultural production. In his opinion, the Academy should carry out all activities in the framework of the general plan of scientific work and agricultural activities in Ukraine in close connection with the All-Union Academy of Agricultural Sciences named after V.I. Lenin and the People's Commissariat of Land Affairs of the Ukrainian SSR.

Well-known agronomist, academician O. Sokolovskiy, one of the organizers of agricultural research case, acknowledged the low level of scientific efficiency in agriculture in Ukraine, the insignificant influence of theoretical developments and their practical use in agricultural production. He noted that such a situation was in some countries of the world, in particular in England, where agricultural science was almost the oldest in Europe. It was also evident that the causes of such a phenomenon were rooted in the factors that formed the human activity of agriculture ${ }^{16}$. The scientist proposed the following classification for the division of research institutions: 1) institutions studying the main factors of agriculture, without the need for their direct adjustment; 2) institutions in small areas with narrow activity mainly practical; 3) institutions that cover theoretical and practical studies of large areas. According to this division, he identified two types of organizational forms - a) research institutes and departments and $b)$ research stations and research fields. Their combined activity was to become a flexible form of scientific associations in the relevant branches of agricultural science, as practiced in Europe.

Prominent organizer of agricultural research case in Ukraine, Prof. S. Kulzhinskiy drew attention to the system of organization of sectoral research in the 20's of the XX century, the main role played by regional agricultural research stations. In connection with the organization of research institutes in Ukraine, it is extremely necessary to establish and coordinate programs of scientific activity between different institutions taking into account their peculiarities: a) radical reorganization of existing forms of organization of agricultural research; b) weak functioning of the system of organization of regional agricultural research stations; c) the failure of these stations to determine the problem and the concept of

\footnotetext{
${ }^{16}$ Соколовський О. Сільськогосподарська наука й життя (Уваги до проблеми організації с.-г. науки на Україні). Вісн. с.-г. науки. 1927. № 1. С. 9-19.
} 
«land»; d) action dispersion regional network stations; e) review of the network of regional research stations, their tasks and methods of work ${ }^{17}$. The scientist believed that research institutes would be able to work efficiently only based on a well-developed in-depth work of district agricultural research stations. The complete transition of research institutions under state centralized subordination threatened the separation of their activities from local needs, transforming the planned principle into bureaucracy.

Ukrainian soil scientist with a world name, Prof. G. Makhov believed that the regional principle of the organization of the research institutions network positively influences the study of the features of natural climatic zones. Direct communication of stations with practical problems of agriculture showed the most effective form of studying natural conditions of the country ${ }^{18}$. The scientist paid attention to the individual factors on which the effectiveness depended, namely: the degree of genetic homogeneity chosen for studying the territory, a significant difference in the regions, which complicated the study and required higher costs of resources. The same conditions accompanied the process of studying the natural productivity of the area and the development of methods for raising it. The significant heterogeneity of natural and climatic conditions characterized the territory of Ukraine, which also had an unequivocal impact on agriculture. This heterogeneity, as noted by G. Makhov, depending on the prevailing influence of factors. The main ones are climate change, which causes the existence of different climatic regions, differences in orography, and differences in surface sediments, vegetation and soil cover. The relationship between natural conditions and economic activity is so great that, while characterizing a certain zone geologically, at the same time its agricultural and economic areas were also projected. The established boundaries of the regions on the basis of the natural-historical features regarding the organization of agricultural research were to correspond to the main physical and geographical zones of the country, which at that time called the edges - Polissia, Forest-steppe right bank, Forest-steppe left bank, East-steppe, West-steppe. The regional research

\footnotetext{
17 Кулжинський С. Крайові сільськогосподарські дослідні станції та спеціальні сільськогосподарські дослідні інститути на Україні. Вісн. с.-г. науки та дослідної справи. 1928. № 6 (T. 5). C. $42-47$.

${ }^{18}$ Махов Г. Естественные границы областей Украины, выделяемых в целях научно-опытного изучения ее территории. С.-х. опытное дело. 1925. № 6. С. 48-52.
} 
organization (regional agricultural research station, district agricultural stations, and special stations) performed a research program in each region.

The results of the study revealed that the main provisions of the construction of a network of research institutions have become the basis for the reconstruction of agricultural research case in Ukraine. The definition of the forms of organization of scientific support for agriculture was accompanied by discussions between the authorities and academics, discussions at various public levels, planning bodies, people's commissariats, scientific institutions and organizations.

\section{Formation of Models of Coordinating Centers for Conducting Agricultural Research}

First, it should be mentioned that the Decree of Nicholas II on the approval of the «Regulation on Agricultural Research Institutions», signed on May 28, 1901 officially recognized the agricultural research case ${ }^{19}$. Prior to this Decree research was the case almost a century way of formation of various branches of scientific knowledge and the search for organizational forms, mainly through private initiative. The functioning of branch societies, research fields and stations as active research centers for the needs of the agricultural sector were a certain stage in the development of agricultural research. The situation changed at the end of the second decade of the last century according to the revolutionary events and the possibility of establishing a coordinating center for agricultural research, the forerunner of the National Academy of Agrarian Sciences of Ukraine the Agricultural Scientist Committee of Ukraine. It based on the agricultural department of the Ministry of Land Affairs and functioned until 1927. The Committee started its activities in accordance with the order of the Minister of Land Affairs Ch 162 on November 1, $1918^{20}$. Academician V. Vernadskiy led it. Despite the unfavorable historical circumstances for the development of agricultural science, it was possible to preserve the experience and traditions developed in relation to the organization of its structure, which united the scientific potential in the agricultural sector of the country.

\footnotetext{
19 Положение о сельскохозяйственных опытных учреждениях. Известия Министерства земледелия и государственных имуществ. 1901. № 29 (22 июля). С. 546-547.

${ }^{20}$ Наказ Міністерства земельних справ. Ч. $162 / /$ ЦДАВО України. Ф. 1061. Оп. 1. Спр. 32. Арк. 202.
} 
First, the Agricultural Scientific Committee of Ukraine began to restore the destroyed branch research institutions. It restored the pre-revolutionary network and launched the organization of new research institutions and higher educational institutions of the agrarian profile. In addition, the Committee created an extensive network of research institutions - a significant number of research stations, research fields, reference points, laboratories, sorted trial sites, etc. It initiated the creation of a number of research agronomic stations. New research institutions began to work under its coordination: the Ukrainian Institute of Applied Botany, the Ukrainian Institute of Plant Protection, the Ukrainian Institute of Animal Husbandry, the Institute of Experimental Soil Science, the Institute of Agronomic Chemistry, the Institute of Seedling, the Institute of Water Management, etc. There were opened a number regions branches in Uman, Vinnytsya, Odessa, Zhytomyr, Poltava, Kyiv, Kamyanets-Podilskiy. The Committee initiated the periodicals edition, among them: «Agronomist», «Bulletin of the Agricultural Scientific Committee of Ukraine», «Herald of Horticulture, Viticulture and Gardening», «Materials of Research», «Young Researcher», «Bulletin of Agricultural Science», «Agricultural Experimental Case», «Ukrainian Agronomist», etc. Periodic print media provide many forms of media - documentary, currently chronological, personal character and so on. Their complex, synthetic character complemented the efficiency of providing information about new research results. The agricultural periodical will become an effective means of popularizing, informational, and scientific support of the agricultural sector, actively promoting its development.

The prominent personalities of national science his leaders played a constructive role in the work of the Agricultural Scientific Committee of Ukraine throughout the entire period of activity: Academicians V. Vernadskiy, P. Tutkovskiy and O. Sokolovsksy, prof. S. Frankfurt, M. Kovalevskiy, I. Shchegoliv, S. Veselovskiy, M. Wolf and academic secretary O. Yanata. The organizational structure created by these scientists, the detailed topics of the problems under investigation, the implementation of the results and their representation, as the researchers point out, according to many features corresponds to the essence of the academic scientific-coordinating institution of the modern type ${ }^{21}$. It should

21 Сільськогосподарський науковий комітет України (1918-1927рр.) : зб. док. і матеріалів. До 75-річчя створення Укр. акад. аграр. наук/УААН, ДНСГБ; уклад. В.А. Вергунов, А.С. Білоцерківська, Б.К. Супіханов, С.Д. Коваленко ; за заг. ред. М. В. Зубця, Ю.Ф. Мельника ; наук. ред. В.А. Вергунов. Київ : Аграр. наука, 2006. 526 с. с. 7 
not ignore the fact that certifies timely and to some extent realized the relevance of such agency, as its structure. In 1924 there were 16 sections (economic, meteorological, experimental agricultural section, chemical, soil sciences section, botanical, zoological, pest control, agricultural household, arable land, horticulture and gardening, meadow farming, agricultural education for promotion and publishing, amelioration, forest, technical) and 9 sub-sectors (weather service, press and publishing, school agricultural education, extracurricular agricultural education, agricultural industry, terminology-translated, agricultural engineering, agricultural construction, entomological). There were also 9 bureau (forest entomology, beekeeping, fish culture, seed science, medicinal plants, weed, phytopathological, floral, museum, editorial and publishing, library and bibliographic, foreign relations, correspondent networks, terminology) and 5 commissions (fight against drought, tobacco, research, environmental protection, zoning). Due to various circumstances, in particular because of reorganization reforms, after a decade of functioning the Bolsheviks liquidated the Committee as supposedly a nationalist institution $^{22}$. However, the results of its successful work on the institutionalization of agricultural research as organization gave the priority in the further system of conducting sectoral research and contributed to the formation of certain features and functions of its focal points.

As evidenced by the documentary sources, on the site of the liquidated Agricultural Scientific Committee of Ukraine the functions of the coordinating body were assigned to the Scientific Advisory Council of the People's Commissariat of Land Affairs of the Ukrainian SSR, created January 11, 1928, in accordance with the decision All-Ukrainian Central Executive Committee and Council of People's Commissars ${ }^{23}$. The Scientific Advisory Council's activity regulated by periodic convocations of sessions. The People's Commissariat of Land Affairs of the Ukrainian SSR approved their programs of work. In accordance with the «Regulations on the Scientific Advisory Board» ${ }^{24}$, the Bureau of the Scientific Advisory Board resolved organizational issues regarding the preparation and conduct of sessions, special meetings and scientific

\footnotetext{
${ }^{22}$ Енциклопедія українознавства : Словникова частина / Наук. т-во ім. Т. Шевченка ; голов. ред. В. Кубійович. Париж ; Нью-Йорк : Молоде життя, 1976. Т. 8. С. 2837.

${ }_{23}$ Тулайков Н. М. Программа работ полеводственного отдела опытной станции. Саратовская с.-х. опытная станция. 1925. С. 3-7.

24 Положення про Науково-консультаційну раду при Колегії Народного Комісаріату земельних справ УСРР // ЦДАВО України. Ф 166. Оп. 6. Спр. 1268. Арк. 15-17.
} 
consultations. It is worth mentioning the main tasks of the Scientific Advisory Board. Among them are:

a) Provision of scientific substantiation of the general plan for the development of agriculture in Ukraine;

b) Coordination and guidance in accordance with the needs of the planned agricultural development research work under the guidance of the People's Commissariat of Land Affairs of the Ukrainian SSR;

c) Assistance in the practical work of the operational departments and institutions of the People's Commissariat of Land Affairs of the Ukrainian SSR through the provision of appropriate scientific advice, expert opinions, development of specific topics, etc.

Together, they provide scientific support to the agricultural sector of the economy Ukrainian SSR.

Given the development of the first five-year plan for the economy in the context of the new public policy, the Scientific Advisory Council's work directed to study problems associated mainly with organizational matters socialist reconstruction of agriculture and in particular - the search for optimal forms its scientific services. Thus, the fore issues singled out and began to study by the Agricultural Scientific Committee of Ukraine: raising of crop yields, livestock development, construction of the Dnipro Hydroelectric Power Station, agricultural zoning, socialization of agricultural production, etc. The special commissions were created under each of these problems. There were engaged to work many wellknown scientists and specialists in various fields of agriculture. The achievements of these commissions subsequently transferred to newly established research institutes, in particular, the Ukrainian Institute of Economics and Agriculture Management at the People's Commissariat of Land Affairs of the Ukrainian SSR. During this period, many other research institutes from the main branches of agriculture - soil science, fertilizers, applied botany, breeding and genetics, and others began their work. At that, in 1927-1930 the members of the Scientific Advisory Council of the People's Commissariat of Land Affairs of the Ukrainian SSR performed the leading role in the active process of institutionalization of agricultural research case in Ukraine, that had took place. It facilitated the coordination and methodological direction of sectoral research for agricultural production needs. 
The Institute of Applied Botany of the People's Commissariat of Education, its staff and loans passed into the People's Commissariat of Land Affairs of Ukrainian SSR according to the protocol number 11/664 «On the reconstruction of the agricultural research case» of the meeting of the Council of People's Commissars of Ukrainian SSR on April 3, 1930. In addition, all the People's Commissariat of Education's research departments of agricultural profile with all states and loans, including graduate students obeyed the People's Commissariat of Land Affairs of Ukrainian SSR - its relevant research institutes as the organization of the last. According to the mentioned protocol, it was determined that it is fundamentally necessary to create such republican research institutes and institutions in the Ukrainian SSR: 1) Institute of Mechanization and Electrification of Agriculture; 2) Institute of Labor Organization in Agriculture; 3) Institute of Falsehood; 4) Institute of Soil Science; 5) Institute of Fisheries; 6) Institute of Plant Protection; 7) Central Agricultural Library. The People's Commissariat of Land Affairs of Ukrainian SSR drew one month to streamline organizational issues with a subsequent submission for approval by the Council of People's Commissars of Ukrainian SSR. The special condition of linking research with agricultural production in practice meant the transfer of simple experiments directly in economies. Ukrainian collective farm center, trust and various centers have mandated full opportunity to carry out this work. In addition, the funding of the network of agricultural research institutions distributed as follows:

$\checkmark$ republican institutions would kept on the state republican budget; special all-Union institutes located in the Ukrainian SSR - on the Union budget with attraction of funds from interested economic organizations;

$\checkmark$ regional stations - on the republican budget with the involvement of funds of interested economic organizations;

$\checkmark$ research work in collective and state farms would conducted by the relevant business organizations.

In some cases, if interested economic organizations are economically strong, with the permission of the Council of People's Commissars of Ukrainian SSR it is possible to transfer the relevant research institutions to the full financing of these organizations. There was the urgent need for scientific personnel. The research institutes of the People's Commissariat of Land Affairs of Ukrainian SSR created postgraduate studies and 
prepared a set of graduate students of the current 1930. In general, the process of institutionalization of agricultural research in the Ukrainian SSR was ambiguous. Often the creation of certain research institutes was considered a separate issue at various levels, especially as regards their subordination and funding sources. The active establishment of research institutes also required the reorganization of universal agricultural research stations, which led to preliminary discussions on the organization of agricultural research affairs by the boundary principle. The changes in the methodology of sectoral research were conditioned by the objectives of the long-term plan for the development of the national economy and the state policy of the closest connection of science and practice in the agricultural sector. Thus, the government approved special research institutes as the optimal organizational form and, accordingly, established a network of industry research institutions of the Ukrainian SSR. They became the basis for the founding of the All-Ukrainian Academy of Agricultural Sciences in accordance with Resolution No. 154 of the Council of People's Commissars of Ukrainian SSR dated 22 May $1931^{25}$.

Thus, the organizational structure of the domestic agricultural research has received a methodological center with functions of control and coordination. We noted that the newly formed Academy methodically obeyed and entered the system of the All-Union Academy of Agricultural Sciences named after V.I. Lenin and funded by the People's Commissariat of Land Affairs of Ukrainian SSR. The All-Union Academy of Agricultural Sciences named after V.I. Lenin includes all agricultural research institutes in the territory of the Ukrainian SSR, branches and the Central Agricultural Library. The coordination of the activities of the Union agricultural research institutes located on the territory of the Ukrainian SSR the All-Ukrainian Academy of Agricultural Sciences documented only with respect to the performance of their work for the republic. In addition to the aforementioned resolution, in accordance with the protocol No. 13/707, the Presidium of the All-Ukrainian Academy of Agricultural Sciences was approved in the following composition: President - Academician O. Sokolovskiy, Vice-Presidents - professors A. Slipansky and T. Bilash, P. Popov and academic secretary Ya. Kharchenko. M. Levenshtam, Prof. I . Bodnar and M. Varpholomeev,

\footnotetext{
${ }^{25}$ Щебетюк Н.Б. Розвиток аграрної науки України наприкінці 20-х - у 30-і рр. XX ст. Кам’янецьПодільський, 2017. С. 137.
} 
K. Vitort elected the members of the Presidium. The results of the research of archival materials prove that the process of formation of the Academy took place during the first year of its work; in particular, it solved the issues of elaboration of the Statute, structure, states, estimates, etc. The personal membership of the Presidium has undergone some changes. New members added. Subsequently the number of its members has reached 18 people. One of the first tasks of the All-Ukrainian Academy of Agricultural Sciences was to study the activities of the existing network of research institutes, zonal stations and support points in order to adapt them to areas of specialization in agricultural production and to ensure the planning of scientific work. I established that the Presidium of the All-Ukrainian Academy of Agricultural Sciences provided methodological direction of scientific work, actualization of topics, etc. through the holding of scientific conferences and meetings.

Since the beginning of 1931, the research institutes of the All-Ukrainian Academy of Agricultural Sciences worked on 1817 scientific problems, 749 of them it completed during the year ${ }^{26}$. The report for the first year of activity contained detailed conclusions on work on the following topics: 1) the task of socialist reconstruction of agriculture; 2) the national economic task of increasing yields by sectoral institutes; 3 ) the fight against drought and the death of winter; 4) providing the industry with raw materials of plant origin; 5) providing the working population with fruits and vegetables; 6) provision of livestock feed to the feed base; 7) on increasing livestock productivity; 8) struggle with costs in animal husbandry; 9) agricultural chemistry; 10) state of mechanization and electrification of agriculture; 11) technical promotion and implementation of scientific achievements; 12) personnel problems; 13) investment and financial condition. Note that the titles of the sections confirmed the exactitude of scientific topics, which Ukrainian scientists-farmers under the leadership of the All-Ukrainian Academy of Agricultural Sciences.

As the analysis showed, the first two years became the fruitful period of activity of the All-Ukrainian Academy of Agricultural Sciences. During 1931-1933, the Academy convened five plenary sessions to discuss numerous issues of the effectiveness of the Academy's structural units, individual projects of organizational and economic strengthening of collective farms, increase of crop yields, etc. In addition, to the

\footnotetext{
${ }^{26}$ Короткий звіт ВУАСГН за 1931 р. // ЦДАВО України. Ф. 1055. Оп. 1. Спр. 242. Арк. 1-42.
} 
achievements of the Academy belongs to the first problem-thematic plan of research work in 1932, which covered the actual issues in various fields of the branch. Its achievement was the replacement of a three-tier system of organization of research works (institute - station - support point) for a two-stage (institute - support point). In general, the support point (support research) became one of the main forms of organization of research work in production and - the primary focus of research work of branch and general institutes.

By 1933, the system of the All-Ukrainian Academy of Agricultural Sciences has operated 142 support points. In addition, in 1934 the Academy network united 7 institutes of the Union and 13 all-Ukrainian significance, 26 zonal stations, 4 reserves and the Central Agricultural Library $^{27}$. Consequently, thanks to the adopted structure, which in 1931 included 4 sectors, in 1933 - already 12, the Academy coordinated the scientific support of agriculture in the Ukrainian SSR. However, the political processes in the USSR in the 1930's delayed the development of many sciences, and agricultural research was no exception. In the spring of 1933, mass arrests of agrarian scholars began to take place. The Academy has suspended its activities. The order of the People's Commissariat of Land Affairs of Ukrainian No. 167 of March 31, 1935 decided to eliminate the All-Ukrainian Academy of Agricultural Sciences ${ }^{28}$. Nevertheless, significant changes have taken place in 1934. The government rebuilt the structure of the network of research institutions of the agricultural sector of the republic in accordance with the decision of the Council of People's Commissars of the USSR and the order of the People's Commissariat of Land Affairs USSR.

I found that in the second half of the 1930's there were significant scientific and organizational changes in the principles and approaches to conducting research in favor of practice, which received a dominant advantage over theoretical developments. The People's Commissariat of Land Affairs of the Ukrainian SSR took over the leadership of agricultural research institutions after liquidation the All-Ukrainian Academy of Agricultural Sciences. In order to provide scientific and methodological guidance to their work at the People's Commissariat of Science, the Scientific Council was established, and for the solution of material, financial and organizational issues - the Scientific-Research Sector was

\footnotetext{
${ }^{27}$ ЦДАВО України. Ф. 1055. Оп. 1. Спр. 130. Арк. 58-59.

${ }^{28}$ Наказ № 167 Народного комісара землеробства УСРР від 31 берез. 1935 р. // ЦДАВО України. Ф. 1055. Оп. 2. Спр. 57. Арк. 71.
} 
organized. In 1940, an organizing committee was created in order to organize the Ukrainian branch of the All-Union Academy of Agricultural Sciences named after V.I. Lenin to unite the work of 165 institutions. However, the Second World War hampered the further reforms.

\section{CONCLUSIONS}

The factors of intensifying the development of agricultural research in the USSR in the 1920's - early 1930's of the twentieth century have shown their influence depending on socio-economic and political changes in society, state policy in the agricultural sector. The process of nationalizing science by the method of coercive and repressive measures unfolded in the harsh conditions of laying and consolidating the foundations of the command-administrative system with the aim of socialist reconstruction of agriculture on the basis of industrialization and collectivization. The question arose about the radical reconstruction of the scientific research on new organizational and methodological principles, about the change in the nature and forms of work. The search for a rational form of interaction between managerial, research and economic institutions began in the context of the challenges of socio-economic reality. The government set the task of solving important problems of the national economy in a short time. Therefore, the search for a new strategy for the approximation of science to solve specific problems of agriculture was carried out through the restructuring of the existing system of sectoral research. The coordinating basis of agricultural research took on distinct forms of institutionalization, and later, academization in the late 20's and early 30's of the XX century under the conditions of the process of politicization, ideologization and programming of science. During this period, the state had taken the decisions on the establishment of sectoral research institutes and their focal points.

During the 20's of the XX century, the state authorities along with scientists sought out optimal forms of control and coordination of research work for the needs of the agricultural sector of the national economy. The creation in 1918 of the Agricultural Scientific Committee of Ukraine contributed to a certain coordination of activities of various departments and organizations. All branch research institutions subordinated to them. The restoration of the activity and the creation of new institutions under the leadership of the Committee established the basis for a modern structure of sectoral research. However, in the late 20-ies, with the strengthening of state planning and control of research in the field of reconstruction of the 
industry, the government created the Scientific Advisory Council instead of the eliminated Agricultural Scientific Committee of Ukraine. This governing body has instituted an agricultural research case for three years and created an extensive network of research institutes of the People's Commissariat of Land Affairs of the Ukrainian SSR. General guidance and methodological coordination in 1931-1935 relied on the All-Ukrainian Academy of Agricultural Sciences.

\section{SUMMARY}

The researcher tries to put forward current issues and questions on the characteristic features of the socio-political life of Ukrainians and the economic situation of the state in the 20-30th of the XX century based on historical and scientific analysis. She shows the impact of a new totalitarian system on the development of the agricultural sector and its scientific support. As shown in the article, he creation in 1918 of the forerunner of the National Academy of Agrarian Sciences of Ukraine - the Agricultural Scientific Committee of Ukraine provided certain coordination between the various departments and organizations that were then subordinated to the sectoral research institutions. The restoration of the activity and the creation of new institutions under the direction of the Agricultural Scientific Committee of Ukraine laid the foundation of the modern structure of sectoral research. Subsequently, the Scientific Advisory Council implemented the institutionalization of agricultural research, laying the foundation for the formation of the academic process. In 1931-1935, the All-Ukrainian Academy of Agricultural Sciences became the coordinating center for scientific support of agricultural development. Thus, the creation and activity of focal points in the form of the Agricultural Scientific Committee of Ukraine, the Scientific Advisory Council and the All-Ukrainian Academy of Agricultural Sciences played a prominent role in the further development of national agricultural research case as a field of knowledge and its organization.

\section{REFERENCES}

1. Баберовскі Й. Червоний терор. Історія сталінізму / пер. 3 нім. Київ : К.І.С., 2007. С. 98.

2. Брайчевський М. Конспект історії України. Київ : Видавн.полігр. центр «Знання», 1993. 203 с.

3. Вергунов В. А. Академізація вітчизняної сільськогосподарської дослідної справи: історико-науковий аналіз. Нариси 3 
історії природознавства і техніки : зб. наук. пр. / Центр досліджень наук.-техн. потенціалу та історії науки ім. Г. М. Доброва НАНУ, Укр. тов-во істориків науки. Київ: Фенікс, 2005. Вип. 45. C. $167-182$.

4. Вергунов В. А. Науково-організаційні засади становлення та діяльності Національної академії аграрних наук України (до 80-річчя заснування НААН) : наук. доп. / НААН, ДНСГБ. Київ: Аграр. наука, 2012. $28 \mathrm{c}$.

5. Всеукраїнська Академія Сільськогосподарських Наук (1931-1935 рр.) : зб. док. і матеріалів. До 75-річчя створення Укр. акад. аграр. наук / УААН, ДНСГБ ; уклад. В. А. Вергунов [та ін.]. Київ, 2006. 311 с.;

6. Дейвіс Норман. Свропа : Історія / пер. 3 англ. П. Таращук, О. Коваленко. Київ : Основи, 2002. 1463 с.

7. Енциклопедія українознавства : Словникова частина / Наук. т-во ім. Т. Шевченка ; голов. ред. В. Кубійович. Париж ; Нью-Йорк : Молоде життя, 1976. Т. 8. С. 2837.

8. Короткий звіт ВУАСГН за 1931 р. // ЦДАВО України. Ф. 1055. Оп. 1. Спр. 242. Арк. 1-42.

9. Кулжинський С. Крайові сільськогосподарські дослідні станції та спеціальні сільськогосподарські дослідні інститути на Україні. Вісн. с.-г. науки та дослідної справи. 1928. № 6. Т. 5. C. $42-47$.

10. Махов Г. Естественные границы областей Украины, выделяемых в целях научно-опытного изучения ее территории. С.-х. опытное дело. 1925. № 6. С. 48-52.

11. Наказ № 167 Народного комісара землеробства УСРР від 31 берез. 1935 р. // ЦДАВО України. Ф. 1055. Оп. 2. Спр. 57. Арк. 71.

12. Наказ Міністерства земельних справ. Ч. 162 // ЦДАВО України. Ф. 1061. Оп. 1. Спр. 32. Арк. 202.

13. Науково-консультаційна рада Народного комісаріату земельних справ УСРР (1927-1930рр.) : зб. док. і матеріалів / НААН, ДНСГБ ; уклад. В. А. Вергунов та ін.. Київ, 2010. 600 с.;

14. П'ятирічки в СРCP // Вікіпедія. Вільна енциклопедія. URL : wiki/П\%27ятирічки_СРСР. (дата звернення: 04.07.2014).

15. Панченко П. П. Сторінки історії України XX століття: (Українське село : поступ, сподівання, тривоги). Київ : ІСДО, 1995. C. 22 . 
16. Положение о сельскохозяйственных опытных учреждениях. Известия Министерства земледелия и государственных имуществ. 1901. № 29 (22 июля). С. 546-547.

17. Положення про Науково-консультаційну раду при Колегії Народного Комісаріату земельних справ УСРР // ЦДАВО України. Ф. 166. Оп. 6. Спр. 1268. Арк. 15-17.

18. Попович М. Сталин. С ним и без него. Зеркало недели. Украина. № 8, 1 марта 2013 г.

19. Сільськогосподарський науковий комітет України (1918-1927 рр.) : зб. док. і матеріалів. До 75-річчя створення Укр. акад. аграр. наук / УААН, ДНСГБ ; уклад. В.А. Вергунов та ін. Київ : Аграр. наука, 2006. 526 с.

20. Снайдер Тімоті. Голод у СРСР. Уривок із книги «Криваві Землі. Свропа між Гітлером та Сталіном». Історична правда. URL: http://www.istpravda.com.ua/research/2011/11/25/62973 (дата звернення: $09.02 .2016)$.

21. Соколовський О. Сільськогосподарська наука й життя (Уваги до проблеми організації с.-г. науки на Україні). Вісн. с.-г. науки. 1927. № 1. С. 9-19.

22. Тулайков Н. М. Программа работ полеводственного отдела опытной станции. Саратовская с.-х. опытная станция. 1925. С. 3-7.

23. ЦДАВО України. Ф. 1055. Оп. 1. Спр. 130. Арк. 58-59.

24. Щебетюк Н.Б. Розвиток аграрної науки України наприкінці 20-х - у 30-і pp. ХХ ст. Кам'янець-Подільський, 2017. 380 с.

25. Юхименко П. І. Економічна історія : навч. посіб. Київ : Вікар, 2004. C. 65 .

26. Яната О. А. Час заснувати Українську академію наук сільськогосподарських. Наука та техніка. 1925. № 2. С. 45-49. с. 45.

Information about the author: Shchebetyuk N. B., Doctor of Historical Sciences, Senior Researcher, Head of the Science Sector, National Scientific Agricultural Library of NAAS 10, Heroes of Defense St., Kyiv, Ukraine 
DOI https://doi.org/10.36059/978-966-397-100-1/164-183

\section{MONASTERIES OF WESTERN DIOCESES OF KYIV UNION METROPOLIYA (90th YEARS OF XVII - 90th YEARS OF XVIII CENTURES): JURISDICTIONAL CONVERSIONS}

\section{Stetsyk Y. O.}

\section{INTRODUCTION}

In today's conditions of building a netting of Basilian monasteries, it becomes necessary to turn to the historical experience of managing monastic communities. After all, the system of administrative management of the Christian ascetic centers has undergone a certain evolution from the complete autonomy (each monastery had its own charter and was independent of each other) to the gradual legal submission to the local bishops first, and subsequently there was a re-subordination to the newly formed authorities of the Proto-Hegumen and the Proto-Archimandrite. The introduction of these governing institutions in the Union Church allowed the creation of an autonomous system of administrative control of the Basilian monasticism, which was subjected neither to the local rulers nor to the Metropolitan of Kiev, and instead it was subjected to papal law. The answer to this right applies to all provinces of the Basilian Order subordinated to the Pope. The considered management system was borrowed from the administrative organization of the Roman Catholic monasteries for a more effective manner of union monastic communities. Accordingly, in our time, when there is a reform of the system of governance, the conditional development of church institutions and the development of society is reflected in the regular updating of the Constitutions of the Order of St. Basil the Great (hereinafter OSBM), it becomes necessary to examine the historical and legal aspects of the establishment of governance institutions that continue to operate in the modern Greek-Catholic Church, which is considered to be the successor to the Union Church. 
The development of the Union Church was accompanied by the introduction of modernization processes, which, above all, were reflected in the reorganization of the system of monastic administration.

At the beginning of the XVII century. the Kyiv Union Metropoliya included most of the ancient orthodox dioceses (Kyiv Metropolitan, Volodymyr-Beresteysk, Polotsk-Vitebsk, Pinsk-Turivsk, Smolensk, Kholm-Belsk), except for Peremyshl and Lviv. Instead, the Lutsk-Ostroh diocese first joined the union, and subsequently returned to orthodoxy. And only in the late 17-th century, in connection with the subordination of the Kyiv Orthodox Church to the Moscow Patriarchate (1686), the idea of the transition of the Western Orthodox dioceses (Peremyshl 1691, Lviv 1700, Lutsk-Ostroh 1702) to the Kyiv Union Metropoliya could be realized.

In this connection, the question arose about the unification of the system of church governance in the newly joined dioceses, in particular, with regard to the management of monasteries, because since 1617 a centralized system of government was introduced in the old union eparchies, with the removal of monasteries from the jurisdiction of bishops, the formation of its own territorial administrative unit (Saint Protection province) and its governing bodies: the Proto-Archimandrite and the general administration.

Accordingly, experiencing a certain imbalance in the management of monasteries, focusing already on the established system of government, the hierarchy of the newly joined dioceses tried to make changes in the leadership of the subordinate local communities by their own efforts. Certain events in this direction were held in the Peremyshl and Lviv dioceses.

\section{Union Monasteries under the Jurisdiction of Bishops (1690-1739 years)}

The unification process in the Peremyshl diocese. At the diocesan council in Peremyshl (1693), in which 10 superiors of the diocese monasteries took part Peremyshl union bishop Innocent Vynnytsky, proposed to conclude new «Rules of the Spiritual Government»" According to the mentioned document, it was proposed to elect a monk Martynian Vynnytsky (who was a brother of the bishop Innocent

\footnotetext{
${ }^{1}$ Winnicki Bp. Innocenty. Ustawy rządu duchownego i inne pisma. Przemyśl : Południowo-Wschodni Instytut Naukowy, 1998. $104 \mathrm{s.}$
} 
Vynnytsky) as the "superintendent" (Proto-Hegumen of the diocese). Every year, the Proto-Hegumen was authorized to visit 22 monasteries of the Peremyshl diocese, to review all foundations, rights and decrees in one collection, to receive financial reports from the abbates, to judge and punish the offenders. Although the Peremyshl cathedral handed over to the Proto-Hegumen, the leadership of all monastic affairs of the diocese, however, he was guided by the instructions of the local bishop when considering various cases. It was also decided that the novitiate-thinning should take place only in three larger monasteries (Shcheplot, Lavrov, Dobromil) ${ }^{2}$.

However, when processing the acts of the Peremyshl Consistory from the first half of the XVIII century, they failed to find documentary evidence of the activity of the eparchial Proto-Hegumen, and, moreover, the results of his work (there are no records of visiting descriptions of monasteries, decrees of court sessions on disciplinary cases of monasticism). Instead of this, monastic affairs were considered in the spiritual court of the Peremyshl diocesan consistory.

The attempts of the Peremyshl bishops Innocent and Yuri Vynnytsky to annex the monasteries of the diocese to the Holy Trinity Province are mentioned in the minutes of the general chapters $(1698,1703,1709)$. In particular, at the Novgorodovycka chapter (1703), a delegation from bishop Yurij Vynnytskyj agreed to attach new monasteries to the Lithuanian province, provided that they preserved the ancient way of ascetic life for them. At the Bilskaya chapter (1709) Yurij Vynnytskyj, already as the administrator of the Kievan Metropoliya, promised to make every effort to unite the monasteries of the newly joined dioceses into one Order and under the direction of one Proto-Archimandrite. However, he failed to realize this intention due to some resistance of the local bishops and monks. Also, in the above mentioned chapter in 1709, the monks of the Lviv diocese protested against the unification of the Rusin and Lithuanian Basilians in one Order, because they differed in the way of life, clothing, and style of management. In addition, the monks from the Lviv diocese reproached the Lithuanian Basilians that they had never worked on unification on those lands, but wanted to come to the prepared ground and conquer their monasteries, to create a separate congregation. However, the greatest fear for the new union monks was because of a different

\footnotetext{
${ }^{2}$ Ibidem. S. $44-45$.
} 
educational level, which was considerably higher in the Lithuanian Basilians ${ }^{3}$.

The unification process in the Lviv diocese. A distinctive confederation of monasteries of the Lviv diocese was created at the Univsky council (1711), which was summoned by Lviv bishop Varlaam Sheptytsky $(1710-1715)$. He assembled superiors and olders fathers from different monasteries (all 42) for the conclusion of the Univ Statute.

In accordance with this statute, the bishop himself was the chief abbat of the confederation. He was assisted by three advisers, who were elected by the monastic council every three years. Their duties were to visit every year monasteries, to control their administrative (foundations, rights, purchases) and disciplinary (to judge and punish offenders, to issue permission to move monks to other monasteries) cases. The hegumenes of the great monasteries were entrusted with conducting financial books, not accepting monks - travelers to their monasteries, visiting small monasteries which were subordinated to them. The abbey of the small monasteries, which were attached to the larger ones, besides the above mentioned orders for the superiors were ordered to no longer cut off the candidates for the monks and not accept their profession. «Collegiate Fathers» (superintendents) should take care to create and keep only one novitiate for the entire Lviv diocese. The council was to be held every three years on the day of St. Joan Baptist. Autonomy remained for each monastery, although the central control over the local bishop was not eliminated ${ }^{4}$.

However, the decretales of this council, apparently, were not implemented, because the Apostolic throne prestige did not approve them, despite of the fact that bishop Varlaam Sheptytsky and the monks repeatedly turned to Rome with this request ${ }^{5}$. The Lviv monks sought the approval of these statutes by Rome, because they did not want to be attached to the Lithuanian Basilians who received the consent of the Congregation for the Propagation of religion in 1705 year $^{6}$.

\footnotetext{
3 Підручний П. Василіянський Чин від Берестейського 3`єднання (1596) до 1743 року. Записки ЧСВВ. Рим : В-во, оо. Василіян, 1992. Серія II. Секція І. Т. 48. С. 169.

${ }^{4}$ Галасливий С. Артикулы или устави чина іноческаго. Лавра. 1999. № 2. С. 41-45.

5 Підручний П. Василіянський Чин від Берестейського з’єднання (1596) до 1743 року. Записки ЧСВВ. Рим : Видавництво ОО. Василіян, 1992. Серія II. Секція I. Том.48. С. 169-171.

6 Welykyj A. Litterae S. Congregationis de Propaganda Fide Ecclesiam Catholicam Ucrainae et Bielarusjae spectantis. Analecta OSBM. Romae : PP. Basiliani,1955. Series II. Sectio III. Vol. II. S. 256.
} 
The council in Zamoscia (1720) was the next preparatory step for the establishment of the Saint Protection province. In accordance with its resolutions, all the monasteries of the newly joined dioceses entering the Union Church were united into one congregation and they chosed their separate Proto-Archimandrite ${ }^{7}$ for four years. The question of the submission of a new Proto-Archimandrite was given at the discretion of the Apostolic throne. However, on February 21, 1721 year, the Lithuanian Basilians submitted a petition to Rome not to approve the drafting of a new Rusin congregation which was separated from the Lithuanian, but only a new province with its Proto-Hegumen, dependent on the ProtoArchimandrite. Metropolit Leo Kishka, together with the hierarchy, learned about the request of the Basilians, wrote to the Congregation for the Propagation of the religion that the new Basilian community would be separated from the Lithuanian one, because one Proto-Archimandrite will not be able to visit all the monasteries even once during the period of its four years administration due to long distances ${ }^{8}$.

The question of the creation of the Rusin Basilian congregation raised again after the approval of the council in Zamoisk by Pope Benedict XIII (1724). Nuncio Vincent Santini (1721-1728) stated support for two separate unions (Lithuanian and Rusin) with two separate ProtoArchimandrite in Warshawa a report to the Congregation for the Propagation of the religion (18.06.1725). In his opinion, such a division must be made in view of the diversity of customs and the difference in the way of monastic life 9 .

Finally, on May 26, 1727 metropolita Leo Kishka convened bishops, archimandrites, and some superiors in Dubno, in order to enforce the council in Zamoscia order of the formation of all the monasteries of the newly joined dioceses of one congregation. The basylian ProtoArchimandryt K. Lebedsky (1727-1792) came to this congress with general counselors. Even before the meetings, he sought that all monasteries be subjected to one Proto-Archimandrite of all Rus, in accordance with the decree of the Congregation for the Propagation of the religion from 1624 year. The bishops also defended their interests, trying

\footnotetext{
${ }^{7}$ Провінційний Синод у Замості 1720 р. Б. / Постанови. Івано-Франківськ : Нова Зоря, 2006. С. 235.

8 Підручний П. Василіянський Чин від Берестейського З`єднання (1596) до 1743 року. Записки ЧСВВ. Рим : В-во, оо. Василіян, 1992. Серія ІІ. Секція І. Т. 48. С. 170.

${ }^{9}$ Підручний П. Історичний нарис законодавства Василіянського Чину Св. Йосафата (1617-2018). Записки ЧСВВ. Рим-Львів, 2018. Серія II. Секція I. Том. 57. С. 197.
} 
to preserve wealthy monasteries for themselves, sought to prevent the Lithuanian Basilians from rejecting the new congregation of the 12 monasteries they occupied in the new union dioceses. However, the Proto-Archimandrite with the general counselors did not agree ${ }^{10}$.

Venedikt Trulevich who was a basilian procurator in Rome for a long time (1712-1724), and in 1727 was a general counselor, in a letter to the secretary of the Congregation for the Propagation of the religion that the metropolit, gathering everyone at the first session, without any formal introductions, said: «...My Fathers! Taking into account that ProtoArchimandrita Order and the Lithuanian province does not want to renounce their monasteries in Volynia, therefore you can not choose a new provincial for you from Volynia. I send the whole thing to Rome, and I release you, go to your monasteries with peace ...» ${ }^{11}$. Hieromonks were dissatisfied with such a message, however, they did not dare to oppose the bishops, as they were still under their jurisdiction. The ProtoArchimandrite and general counselors barely asked the metropolitan to hold another lunch session, during which they proved that this was not about the removal of monastic possessions from the Lithuanian province, but about the choice of a new Proto-Hegumene. The gathered monks also asked to allowe them to choose a Proto-Hegumen, but the metropolitan, on behalf of all the bishops, repeated the same as at the first session, and ordered all to disperse ${ }^{12}$.

On the same day (May 26, 1772) metropolitan Kishka wrote a report to the Congregation for the Propagation of the religion, in which he declared that it is difficult and even impossible to create a Rusin province without the monasteries they occupy in the aforementioned dioceses the Lithuanian Basilians ${ }^{13}$. However, Warshawa nuncio Santini with, reporting on this case of the Congregation (June 25, 1727), said: «... It seems to me that the claims of the mentioned bishops are of no greater impor-

\footnotetext{
${ }^{10}$ Підручний П. Василіянський Чин від Берестейського З`єднання (1596) до 1743 року. Записки ЧСВВ. Рим : В-во, оо. Василіян, 1992. Серія II. Секція І. Т. 48. С. 171.

11 Welykyj A. Litterae S. Congregationis de Propaganda Fide Ecclesiam Catholicam Ucrainae et Bielarusjae spectantis. Analecta OSBM. Romae : PP. Basiliani,1955. Series II. Sectio III. Vol. II. S.157.

${ }^{12}$ Welykyj A. Epistolae Metropolitarum Kioviensium Catholicorum Leonis Kiśka, Athanasii Szeptyckyj, Floriani Hrebnyckyj (1714 - 1762). Analecta OSBM. Romae : PP. Basiliani, 1959. Series II. Sectio III. Vol. IV. S. 143.

${ }^{13}$ Welykyj A. Epistolae Metropolitarum Kioviensium Catholicorum Leonis Kiśka, Athanasii Szeptyckyj, Floriani Hrebnyckyj (1714 - 1762). Analecta OSBM. Romae : PP. Basiliani, 1959. Series II. Sectio III. Vol. IV. S. 144.
} 
tance .... ${ }^{14}$. Some monks of the newly-joined monasteries confessed to. $\mathrm{V}$. Trulevich that it is quite difficult for bishops to renounce those monasteries and monks through material revenues ${ }^{15}$.

The following year (19.04.1728), the Congregation for the Propagation of the religion had a long time pondering on the question: «Can the Basilian monasteries be united in the Polish kingdom and the Grand Lithuania principality into one unit?». They decided to organize, but without distinction of the monasteries of the Lithuanian congregation, and the new congregation should submit directly to the Apostolic capital ${ }^{16}$. However, the decision remained only on paper, because the Congregation for the Propagation of the religion had not informed anyone about it.

They returned to the creation of the new Basilian Russian congregation 19 years after the council in Zamoscia (1720) at the Lviv general chapter (1739), which was convened by metropolitan Atanasy Sheptytsky (1729-1746). The monks of the Lviv diocese, led by Innocent Pigovich, Sylvester Malsky and Anton Pidhirsky, initiated its convocation. They (together with others) sought from their bishops the unification of all the monasteries into a single whole and they sought to do so in Rome ${ }^{17}$. The bishops were late with the matter because they did not have enough profits and foundations. They realized that their profits would decrease right after the formation of a new congregation. Metropolitan Atanasy Sheptytsky convened this chapter, because he was pressured by the Lithuanian Basilians, newly united monasteries and the Congregation for the Propagation of the religion. In particular, the last institution repeatedly recalled that the council in Zamoscia should be executed ${ }^{18}$.

Thus, the institutional formation of the Saint Protection Province was preceded by a rather long period of search for various ways of uniting the monasteries of the western dioceses of the Kyiv Union Metropolitanate. During the first half of the XVIII century. various projects were created to unify the monastic communities ("Rules of the Spiritual Government"

14 Wojnar M. De regimine Basilianorum Ruthenorum a metropolita Josepho Velamin Rutskyj instauratorum. Analecta OSBM. Romae : PP. Basiliani,1949. Ser. II. Sec. I. Vol. I. S. 78.

${ }^{15}$ Підручний П. Історичний нарис законодавства Василіянського Чину Св. Йосафата (1617-2018). Записки ЧСВВ. Рим - Львів, 2018. Серія II. Секція І. Том. 57. С. 197.

${ }^{16}$ Welykyj A. Congregationis Particulares Ecclesiam Catholicam Ucrainae et Bielarusjae spectantes (1729-1869). Analecta OSBM. Romae : PP. Basiliani, 1956. Series II. Sectio III. Vol. I. S. 259.

${ }^{17}$ Welykyj A. Supplicationes Ecclesiae Unitae Ucrainae et Bielarusjae (1720-1740). Analecta OSBM. Romae : PP. Basiliani, 1963. Series II. Sectio III. Vol. II. Doc. N 837, 849, 860.

${ }^{18}$ Підручний П. Історичний нарис законодавства Василіянського Чину Св. Йосафата (1617-2018). Записки ЧСВВ. Рим-Львів, 2018. Серія II. Секція І. Том. 57. С. 198. 
(Peremyshl, 1693), "Articles or Orders of the Monastic Order" (Univ, 1711), but none of them could be fully realized. However, the resolutions in question expressed the interests of the local church hierarchy, which did not want to lose jurisdiction over diocesan monasteries, trying to create a dualistic system of governance (bishop - proto-hegumen). As a result, this gave rise to confusion and confrontation and they were trying to solve the problem for a long time. Even the decisive decrees of the council in Zamoiscia (1720) concerning the unification of monasticism were not immediately enforced, as it was necessary to wait for a long 19 years when the new monasticism managed to create a separate congregation and the Rusin province, reaching a certain consensus with the basilians of the Lithuanian province.

\section{Formation of Autonomous Governance System}

(1739-1793)

Metropolitan of Kiev, Atanasy Sheptytskyj, was summoned and chaired by the Lviv general chapter (August 26, 1739 in the St. George's Cathedral). From the protocol, we learn that at the second meeting the Constitution of Novgorodovitskaya chapter (1617) was read to those who were present, and at the third session, on the basis of the same constitutions, a new Congregation for the Protection of the Blessed Virgin Mary (Saint Protection, Ruska, Polish or Crown Province) was created on the basis of the same Constitutions. The newly formed province included more than 130 monasteries (85 larger, approximately 100 small or very small ascetic centers) and 700 monks living in the territory of the Polish Kingdom.

A protoarchimandrite for a new province was selected. He became, at the suggestion of Atanasy Sheptytsky, Fr. Patrick Zhyravsky (general consulate of the Lithuanian Basilians), for a term of four years. He should have to introduce into the newly-formed monasteries such a pattern that operated in the Lithuanian-Belarusian monasteries, the traditional Basilian discipline. To assist in managing the province (also for four years), the general consuls were elected. In addition, the chapter concluded 34 rules, such as the Chapter Constitutions of the Lithuanian Congregation of the Holy Trinity ${ }^{19}$. Apparently, in the year 1740, "General Rules" of

19 Центральний державний історичний архів України у м. Львів. Ф.408. «Греко-католицький митрополичий ординаріат. м. Львів». Оп.1. Спр.974. «Протокол генеральної капітули василіанських монастирів у Львові» (копія, 1739 р.). Арк. 3-4. 
Metropolitan Joseph Rutsky were published by the efforts of the new protoarchimandrite in Pochayev. According to Anton Petrushevich, this publication was, in essence, a reprint of the Supral Editorial Office Fr. Dmitry Zankiewicz from 1717 year $^{20}$.

At the second session of the Lviv Chapter (1739), the bishops refused to administer monasteries in their dioceses, but instead agreed to pass them under the authority of the newly formed provincial council, leaving in their subordination only the possession of small monasteries in which there were not enough foundations for the maintenance of 12 monks, as attributed to the council in Zamoscia (1720).

In the formal act of the foundation, the Lithuanian Archpriest W. Polatylo and the general consulates made a point that the hieromonks of the newly formed province were instructed to take measures to unite the two Basilian communities into one Order ${ }^{21}$.

Before proceeding to the constitution (at the sixth session), the decree of the six first chapters, which was held for Metropolitan Joseph Rutsky, was read. Focusing on them, the Lviv Chapter made 34 rules. The decision was made to elect a protoarchimandrite for four years from among ordinary monks. He was assigned the task of visiting the monasteries, appointing hegumen, convening every four years of the chapter, in accordance with the agreement that metropolitan Zhokhovsky concluded with the Lithuanian congregation in 1686 year. According to this agreement, the general consulates had to assist the Proto-Archimandrit, who was chosen by the chapter for four years, and not for the whole life, as was in the Holy Trinity province. General and particular rules, concluded in 1617 year by the Kiev Union Metropolitan Joseph Rutsky ${ }^{22}$ were introduced in the monasteries included in the newly formed Saint Protection Province.

The institute of the Proto-hegumenat was instituted in 1743 in the Union Church in connection with the unification of the two monastic Congregation of the Holy Trinity (the Lithuanian province) and the

\footnotetext{
${ }^{20}$ Підручний П. Василіянський Чин від Берестейського з'єднання (1596) до 1743 року. Записки ЧСВВ. Рим: Видавництво ОО. Василіян, 1992. Серія II. Секція I. Том.48. С. 172.

21 Центральний державний історичний архів України у м. Львів. Ф.408. «Греко-католицький митрополичий ординаріат. м. Львів». Оп. 1. Спр. 974. «Протокол генеральної капітули василіанських монастирів у Львові» (копія, 1739 р.). Арк. 11.

${ }^{22}$ Центральний державний історичний архів України у м. Львів. Ф.408. «Греко-католицький митрополичий ординаріат. м. Львів». Оп. 1. Спр. 974. «Протокол генеральної капітули василіанських монастирів у Львові» (копія, 1739 р.). Арк. 8-9.
} 
Protection of the Blessed Virgin (Rusin province) into one Rusin Church of St. Basil the Great (Ordo Sancti Basilii Magni Ruthenorum). In accordance with the decisions of the general chapter in Dubno (May 26 - June 12, 1743), Pope Benedict XIV issued the decree "Inter plures" (May 2, 1744), which approved the unification of the Rusin and Lithuanian union monasteries into one Order $^{23}$.

At the same meeting, the general constitutions were adopted, which defined the responsibilities of the new union Order. In particular, it was determined that each monastic province has the right to establish its own council, which consisted of a proto-hegumen, four counselors and one secretary. These governments were elected. Elections of provincial councils were held at provincial chapters (provincial monastic councils) every four years. The provincial chapter was summoned and chaired by the Proto-Archimandrite (led by the whole order and the provincial Protohegumens were subordinated to him and assisted him by the general administration) or by his delegate. The main duty of the proto-hegumen was to supervise the observance of monastic discipline in the monasteries. Accordingly, the proto-hegumen was obliged to visit the provincial monasteries annually, to write reports on the results of his conduct and send them to the proto-archimandrite. On the general chapters, the protohegumen submitted a general report on canonical visitation. In addition, the proto-hegumen, with the consent of the provincial counselors, appointed superiors for small monasteries, and for large monasteries he nominated a candidate for approval to the proto-archimandrite ${ }^{24}$.

Since 1766, there are suggestions that it is better to divide Order into more provinces. First of all, this division required intensive administrative work: a great distance between the monasteries, an increase in the number of monasteries and monks. As a result, the proto-hegumen did not have the opportunity to visitation every year. By that time the Basilian Order expanded its network of monasteries around the whole of Belarus and throughout the Right-Bank Ukraine. Accordingly, the Brest's general chapter of 1772 approved the division of Order, calling it useful, but advised not to realize the execution of this ruling until better times ${ }^{25}$.

\footnotetext{
${ }^{23}$ Підручний П. Історичний нарис законодавства Василіянського Чину Св. Йосафата (1617-2018). Записки ЧСВВ. Рим-Львів, 2018. Серія II. Секція I. Том. 57. С. 218.

${ }^{24}$ Підручний П. Історичний нарис законодавства Василіянського Чину Св. Йосафата (1617-2018). Записки ЧСВВ. Рим-Львів, 2018. Серія II. Секція I. Том. 57. С. 219.

${ }^{25}$ Патрило І. Нарис історії Василіян від 1743 до 1839 р. Записки ЧСВВ. Рим : В-во, оо. Василіян, 1992. Серія II. Секція I. Т. 48. С. 222.
} 
However, not these discussions, but international socio-political changes have become the reason for the division of the Order. Six months after the completion of the Brest's general chapter, the first division of the Rech Pospolita was held on 05.08.1772. As a result of this division, the Basilian monasteries were scattered among the three political state entities: the Russian and Austrian empires and the still existing Polish kingdom.

At this turning point, the Order had 150 monasteries and 1235 monks (without newcomers). It was the largest Order on the UkrainianBelarussian lands, one of the largest in the whole of Poland. When in 1773 the Society of Jesus began to be liquidated in Poland, the Basilians could take over 20 secondary schools ${ }^{26}$.

In his report to the prefect of the Congregation for the Propagation of the religion (04.04.1774) Nuncio J. Garampi (1772-1775) submitted the statistical status of the Basilian Order: under the Russian Empire there were 20 monasteries and 153 monks; under the Austrian Empire 42 monasteries and 319 monks; under the Polish kingdom there are 82 monasteries and 753 monks $^{27}$.

Until 1780 the Austrian government (under the reign of empress Maria-Teresa) did not interfere in the internal affairs of the Basilian Order, giving freedom to move and correspondence. Instead, the Russian government first initiated the conversion of the Union to Orthodoxy, however, until 1784, it did not interfere in the internal affairs of the Basilian Order too. Thus, in 1780 all the Basilians could jointly hold the general chaper in Torokany. However, it was already the last general chaper, which represented all the monasteries of Order ${ }^{28}$.

When before the chapter in Torokany, the administration of Order approached Pope Pius VI (1775-1799) with a request, he, with his rescript dated April 24, 1780, allowed the division of the Order, but demanded that the consent of all the capitulations of the hieromonks would agree to vote in the division of the Order into four provinces but after the election of the main administration ${ }^{29}$. However, on the one side, the nuncios saw the need

\footnotetext{
26 Wojnar M. De regimine Basilianorum Ruthenorum a metropolita Josepho Velamin Rutskyj instauratorum. Analecta OSBM. Romae : PP. Basiliani,1949. Ser. II. Sec. I. Vol. I. S. 99-100.

27 Wojnar M. De regimine Basilianorum Ruthenorum a metropolita Josepho Velamin Rutskyj instauratorum. Analecta OSBM. Romae : PP. Basiliani,1949. Ser. II. Sec. I. Vol. I. S. 100.

${ }^{28}$ Патрило I. Нарис історії Василіян від 1743 до 1839 р. Записки ЧСВВ. Рим : В-во, оо. Василіян, 1992. Серія II. Секція I. Т. 48. С. 223.

${ }^{29}$ Bulle, brevia y listy okolne papieskie tudzież Kongregacyi dekreta, obrządkowi greckiemu ziednoczonemu służące, z różnych xiążek, tudzież bullaryuszu Benedykta XIV zebrane, z łacińskiego ięzyka na polski przełożone, z przydatkiem powinności i obowiązków XX. Parochów i inszych kapłanów, z synodu Zamoyskiego Ruskiego Prowincyalnego wyiętych. Wydrukowane w Supraslu w drukarni uprzywilejowaney XX. Bazylianów: za wiadomościę i pozwoleniem P. K. J. K. Mości Białostockiey, Roku 1799. S. 36.
} 
for division of the Order and, on the other side, he saw the difficulty in fulfilling the papal rescript, and having no time to turn to Rome, he freed himself from those conditions, and for this he subsequently received praise from the Congregation for the Propagation of the religion ${ }^{30}$.

At the chapter in Torokany, the majority of votes decided that the division of the Order in the province is necessary. Then a draft of the division was concluded, so that on 17.09.1780, four Basilian provinces were formed: 1. Byelorussian (St. Nicholas) for the monasteries that had fallen into the Russian Empire. 2. Galician (Holy Salvator), covering Galicia, Holmshchyna and under the Austrian Empire. 3. Lithuanian (Holy Trinity). 4. Polish (Protection of the Mother of God) ${ }^{31}$. These two last remained under the control of the Polish kingdom.

Thus, the result of the reorganization of the ancient Protection province was the formation of two provinces: Polish and Galician. So let's consider the initial period of the functioning of these new entities during 1780-1793.

The Galician Saint Salvatoris province, which separated from Saint Protection one, consisted of 36 monasteries and 10 residences (as of 1780) located on the territory of the rusin lands that went to the Austrian Empire, according to the first division of the Rech Pospolita: monasteries - Bilche, Chernilyava, Chortkiv, Darevlyany, Dobromil, Domashiv, Drohobych, Goshiv, Yazenitsa, Krasnopushcha, Krekhiv, Krylos, Krystinopil, Lviv St. Ivan Evangelist, Lviv St. Yura, Lvov St. Onufriya, Lavriv, Luka, Pidhirtsi, Pogonya, Sokulets, Strushiv, Shcheploty, Spas, Terebovlya, Uhornyky, Ulashkovtsi, Univ, Verhrta, Vitsyna, Zadariv, Zamosty, Zavaliv, Zbarazh, Zolochiv, Zhovkva; residences - Lanovtsi to Bilchik, Horpin to Derevyane, Paciwik and Swaricz to Goshiv, Pitrichen to Krylos, Bilin Velya to Lavrov, Topolnitsa to Spas, Yamnica to Verhraty, Buchin to Zolochiv, Basidy to Zhovkva ${ }^{32}$.

During 1772-1780, the Austrian government did not create obstruction for monasticism, henceforth the main activities of the Order remained. Austrian government officials took part in the Torokan's

30 Welykyj A. Litterae S. Congregationis de Propaganda Fide Ecclesiam Catholicam Ucrainae et Bielarusjae spectantis. Analecta OSBM. Romae : PP. Basiliani,1956. Series II. Sectio III. Vol. VI. S. 96.

${ }^{31}$ Патрило I. Нарис історії Василіян від 1743 до 1839 р. Записки ЧСВВ. Рим : В-во, оо. Василіян, 1992. Серія II. Секція I. Т. 48. С. 223.

${ }^{32}$ Cathalogus Professorum Ordinis S. B. Magni provinciae Protectionis Beatissimae Virginis Mariae juxta Ordinem Alphabetici in Monasteriorum ex Anno 1778 in Annum 1779. Typis S.R.M. Monaste: Poczajovien: O.S.B.M. Anno Domini, 1778. 
general chapter (1780). After that, the religious policy has changed. The Austrian Emperor Joseph II issued a decree in 1782, forbidding all monastic congregations who were in the empire, subject to provincial councils that were outside the state. Therefore Galician Basilian monks could not take part in general chapters that took place in Zhidychin in Volhynia (1788) and Torokany (1802). Instead, they convened only the provincial chapters in Galicia.

Another imperial decree of April 17, 1783 required the union of small and poor monasteries with larger and more prosperous. The jurisdiction of the monasteries, which subsequently returned to the subordination of local bishops, also changed. Each diocese received the right to form a separate monastic province on its territory. Accordingly, the Galician province was divided into two parts: Lviv and Peremyshl, according to the current administrative-territorial division of the Greek Catholic Church in the territories of Galicia ${ }^{33}$.

On March 8, 1783 bishop of Lviv Petro Bilyanskyi, appointed Fr. Victor Starozhinsky Commissioner and General Visitor of the Basilian Monasteries in the territory of the Lviv diocese. Anastasiy Piotrovsky who was elected to the general chapter in Torokany (1780) remained the proto-hegumen of the Galician province and now he cared only over the monasteries located within the Peremyshl diocese. In June 1783 a chapter was held in which the abbots of only those monasteries that were located on the territory of the Lviv diocese took part. According to the will of the delegates of this assembly, the patron of their "province" should have been St. Onuphrius, and Lviv was the seat of the proto-hegumen. Formally, the Lviv part of Saint Salvatoris province was headed by Fr. Victor Starozhinsky. However, according to O. Duh, relying on the worked out sources, he never signed the documents as a proto-hegumen, but only as a commissar and visitator until the next chapter, which took place in 1785. In the second half of 1783 and during the following year, Starozhinsky conducted a number of visits to the monasteries subordinate to the Lviv diocese ${ }^{34}$.

33 Саламаха М. Трансформація структури Чину Святого Василія Великого в останній третині XVIII ст. Науковий вісник Східноєвропейського національного університету імені Лесі Украӥнки. Серія: Історичні науки. 2015. № 7 (308). С. 17.

34 Дух О. Віктор Василь Старожинський (1740-1808) - протоігумен Галицької провінції ЧСВВ і Жовківський архимандрит. Наукові зошити історичного факультету Львівського університету. 2012-2013. Вип. 13-14. С. 237. 
During 1783-1785 he published a number of official letters directed to the abbots of the Basilian monasteries in the territory of the Lviv diocese. In particular, on December 11, 1784, he signed a letter in which, according to the instructions of the Austrian administration, Starozhinsky ordered the monastic community to elect the abbots independently for a term of three years.

In early 1785 the Basilians in Galicia again received permission to unite all their monasteries into one province. A provincial chapter, at which Victor Starozhinsky was elected proto-hegumen of the union Galician's Saint Salvator province was held on May 15, 1785 in the monastery of St. Jura in Lviv. On September 20, 1785, he issued a diligent letter, referring to the orders of the monastic statutes and the constitutions of the general chapters and giving instructions on the fulfillment of monastic vows.

In 1787-1790 Starozhinsky made considerable efforts to save the Basilian monasteries in Galicia, which, according to the decision of the Austrian authorities, had to be abolished. There are numerous letters of proto-hegumen to the organs of state power in which he speaks with arguments in favor of the existence of individual monasteries. Due to his efforts, monasteries were saved in Lavrov, Pidhirtsi, Pogonya, Goshev, Vitsyn, Ulashkivtsi, Krystynopol, Zhovkva and Zamoscia, but Univs'k Archimandria could not be saved.

The proto-hegumen Victor Storozhinsky also failed to obtain permission to restore the Basilian monasteries of philosophical and theological studies because since that time the training of future Greek Catholic priests was focused on the theological faculty of Lviv University and the General Greek Catholic Seminary ${ }^{35}$.

The more favorable circumstances for the development of monasticism were formed by the Emperor Franz II (1792-1806), when a number of restrictive decrees were abolished, but the proto-hegumen institute had undergone significant changes because the proto-hegumen elected at the congregation had to be approved both by the Austrian government and the local bishops at the same time. Only $26^{36}$ monasteries out of the 36 ones (1780) remained at the beginning of the XIX century.

\footnotetext{
35 Дух О. Віктор Василь Старожинський (1740-1808) - протоігумен Галицької провінції ЧСВВ і Жовківський архимандрит. Наукові зошити історичного факультету Львівського університету. 2012-2013. Вип. 13-14. С. 238.

${ }^{36}$ Саламаха М. Трансформація структури Чину Святого Василія Великого в останній третині XVIII ст. Науковий вісник Східноєвропейського національного університету імені Лесі Украӥнки. Серія: Історичні науки. 2015. № 7 (308). С. 17.
} 
The reorganized Saint Protection province, continued to remain in the Polish kingdom, uniting 33 monasteries from the first (1772) to the second (1793) divisions of the Rech Pospolita. Within the region of Volyn there were monasteries in Bialystok, Goscha, Gorodische, Zagaytci, Zagory, Zimno, Kremenets, Lutck, Lyubar with Kolodzhne, Milltsy, Milchy, Nyzkynychi, Ostrog, Poddubtci, Pochayiv, Puginky; Podillia - Bar, Golovchintsy, Kamyanets, Korzhivtci, Malievtci, Sataniv; Kyivshchyna Bilylivka, Kaniv, Lysyanka, Ovruch, Trigirya; Bratslavshchyna - Graniv, Uman, Shargorod, Straklov, Tumin, Chetvertnya, as well as two monasteries from the territories of Poland - Lublin, Warshawa ${ }^{37}$.

After the second division of the Rech Pospolita (1793), when Saint Protection province became part of the Russian Empire, the new authorities launched a targeted attack on the rights of the Basilian Order. On December 12, 1793 a decree on the transfer of monasteries into the jurisdiction of local bishops was issued. This was the beginning of the province's loss of its self-governing status. Subsequently, in 1795, the Kyiv Union Metropolitanate and its diocese were liquidated. The Basilians were forbidden to recognize any jurisdiction outside the country, accept and pronounce the papal without the permission of the supreme secular authorities. Accordingly, Order finally lost his self-government, and Archibishop I. Lisovsky took over the functions of the Proto-Archimandrite and Proto-Hegumene with the right to visit the monasteries ${ }^{38}$.

\section{CONCLUSIONS}

At the end of XVII - early XVIII century the gradual occurrence of the Western Orthodox dioceses to the Kyiv Union Metropolis caused a certain jurisdictional imbalance in the management of the monasteries, which at different times adopted a conscientious belief. The monks, which recognized the articles of the Brest Union soon after their proclamation, were withdrawn during the first quarter of the XVII century. from the jurisdiction of local bishops. However, their jurisdictional affiliation has also undergone a certain evolution: Metropolitan - Proto-Archimandrite - Proto-Hegumen. Certain transformations have undergone the foundations of the monastic administration and among the monks, who later joined the unified faith.

37 Ваврик М. Нарис розвитку і стану Василіянського Чина XVII - XX ст. Топографічностатистична розвідка. Записки ЧСВВ. Рим, 1979. Серія II. Секція I. Т. ХІ. С. 178.

38 Саламаха М. Трансформація структури Чину Святого Василія Великого в останній третині XVIII ст. Науковий вісник Східноєвропейського національного університету імені Лесі Украӥнки. Серія: Історичні науки. 2015. № 7 (308). C. 19. 
During the transitional period (from 90-th XVII to 30-th XVIII), the union monks of the western dioceses continued to be within the jurisdiction of the bishops who, in Order to preserve their influence, developed various projects for the unification of diocesan monasteries, which were supposed to be governed by the regional superintendents (proto-hegumens). However, in practice, the projects that were developed did not succeed, as disciplinary cases of monasticism continued to be considered in the spiritual courts of the local bishops.

And only the perseverance of the Apostolic sedes forced the new union rusin monks to take control of the Lithuanian Basilians. Of course, this transformation process was accompanied by certain dissatisfaction, both from the part of local bishops and monks. If bishops did not want to lose power over the monasteries, where certain estates were concentrated, the rusin monasticism did not show any commitment to union with the Lithuanians, trying to preserve the independence of the authorities. Due to its persistence, the rusins succeeded in securing the formation, at the beginning, of an independent monastic administrative unit - the Saint Protection province with a separate proto-archimandrite. However, subsequently, the unification of two provinces (Rusin and Lithuanian) took place in one of the Rusin Order of St. Basil the Great, led by one protoarchimandrite (general), and its provinces - two proto-hegumenes (provinces).

The developed and tested three-level control system (protoarchimandrite - proto-hegumene - superior) made it possible to effectively manage a large number of monasteries that were scattered among different diocesies of the Kyiv Union Metropolitanate. Such an approach allowed centralizing the monastic control system to strengthen discipline and order in monasteries. The introduction of a unified monastic statute made the life of the monks more regulated and purposeful.

However, international socio-political changes caused by the three divisions of the Rech Pospolita led to the return of Basilian monasticism to the subordination of local bishops. These measures, initiated by the Austrian and Russian emperors, led to the decline of the Basilian Order. In particular, in the Austrian Empire, it found expression in reducing the number of monasteries and monks, and in the Russian monarchy in the gradual restriction of the rights of the Order and its complete elimination. 


\section{SUMMARY}

The development of the control system of the Basilian monasteries has been considered, which has changed the jurisdictional affiliation from the episcopat to the proto-archimandrite governments and vice versa. The regional projects on unification of monasteries at the level of diocesies (Peremyshl and Lviv) have been analyzed. The influence of the council in Zamoiscia decisions on the intensification of the process of uniting rusin monasteries into one monastery of the Congregation is outlined. The circumstances of the formation of the autonomous monastic administrative unit of the rusin monks - Saint Protection province are considered. It has been determined how international social and political events led to the return of monasteries to the jurisdiction of local bishops. The three-level system of control by the Basilian Order (proto-archimandrite - protohegumene - superior) is analyzed. The consequences of centralization of the monastic control system are determined. The process of reorganization of the Saint Protectione province is revealed. It is shown how the entrance of monasteries to different empires (Russian and Austrian) influenced the change of the administration of the Basilian monasticism.

Key words: basilians, bishop, proto-archimandrite, proto-hegumen, superior.

\section{REFERENCES}

1. Ваврик М. Нарис розвитку і стану Василіянського Чина XVII - XX ст. Топографічно-статистична розвідка. Записки ЧСВВ. Рим, 1979. Серія II. Секція I. Т. ХI. 218 с.

2. Bulle, brevia y listy okolne papieskie tudzież Kongregacyi dekreta, obrządkowi greckiemu ziednoczonemu służące, $\mathrm{z}$ różnych xiążek, tudzież bullaryuszu Benedykta XIV zebrane, z łacińskiego ięzyka na polski przełożone, z przydatkiem powinności i obowiązków XX. Parochów i inszych kapłanów, z synodu Zamoyskiego Ruskiego Prowincyalnego wyiętych. - Wydrukowane w Supraslu w drukarni uprzywilejowaney XX. Bazylianów: za wiadomościę i pozwoleniem P. K. J. K. Mości Białostockiey, Roku 1799.

3. Cathalogus Professorum Ordinis S. B. Magni provinciae Protectionis Beatissimae Virginis Mariae juxta Ordinem Alphabetici in Monasteriorum ex Anno 1778 in Annum 1779. Typis S.R.M. Monaste: Poczajovien: O.S.B.M. Anno Domini, 1778. 
4. Welykyj A. Congregationis Particulares Ecclesiam Catholicam Ucrainae et Bielarusjae spectantes (1729-1869). Analecta OSBM. Romae : PP. Basiliani, 1956. Series II. Sectio III. Vol. I.

5. Welykyj A. Epistolae Metropolitarum Kioviensium Catholicorum Leonis Kiśka, Athanasii Szeptyckyj, Floriani Hrebnyckyj (1714-1762). Analecta OSBM. Romae : PP. Basiliani, 1959. Series II. Sectio III. Vol. IV.

6. Welykyj A. Litterae S. Congregationis de Propaganda Fide Ecclesiam Catholicam Ucrainae et Bielarusjae spectantis. Analecta OSBM. Romae : PP. Basiliani, 1955. Series II. Sectio III. Vol. II.

7. Welykyj A. Litterae S. Congregationis de Propaganda Fide Ecclesiam Catholicam Ucrainae et Bielarusjae spectantis. Analecta OSBM. Romae : PP. Basiliani, 1956. Series II. Sectio III. Vol. VI.

8. Welykyj A. Supplicationes Ecclesiae Unitae Ucrainae et Bielarusjae (1720-1740). Analecta OSBM. Romae : PP. Basiliani, 1963. Series II. Sectio III. Vol. II.

9. Winnicki Bp. Innocenty. Ustawy rządu duchownego i inne pisma. Przemyśl : Południowo-Wschodni Instytut Naukowy, 1998. 104 s.

10. Wojnar M. De regimine Basilianorum Ruthenorum a metropolita Josepho Velamin Rutskyj instauratorum. Analecta OSBM. Romae : PP. Basiliani,1949. Ser. II. Sec. I. Vol. I. S. 78-100.

11. Галасливий С. Артикулы или устави чина іноческаго. Лавра. 1999. № 2. C. 41-45.

12. Дух О. Віктор Василь Старожинський (1740-1808) протоігумен Галицької провінції ЧСВВ і Жовківський архімандрит. Наукові зошити історичного факультету Львівського університету. 2012-2013. Вип. 13-14. С. 235-242.

13. Патрило I. Нарис історії Василіян від 1743 до 1839 р. Записки ЧСВВ. Серія II. Секція І. Т. 48. Рим : В-во, оо. Василіян, 1992. C. 184-278.

14. Підручний П. Василіянський Чин від Берестейського З`єднання (1596) до 1743 року. Записки ЧСВВ. Рим : В-во, оо. Василіян, 1992. Серія II. Секція I. Т. 48. С. 96-183.

15. Підручний П. Історичний нарис законодавства Василіянського Чину Св. Йосафата (1617-2018). Записки ЧСВВ. Рим-Львів, 2018. Серія II. Секція I. Том. 57. 392 с. 
16. Провінційний Синод у Замості 1720 р. Б. / Постанови. ІваноФранківськ: Нова Зоря, 2006. 304 с.

17. Саламаха М. Трансформація структури Чину Святого Василія Великого в останній третині XVIII ст. Науковий вісник Східноєвропейського наиіонального університету імені Лесі Украӥнки. Серія: Історичні науки. 2015. № 7 (308). С. 15-21.

18. Центральний державний історичний архів України у м. Львів. Ф.408. «Греко-католицький митрополичий ординаріат. м. Львів». Оп. 1. Спр. 974. «Протокол генеральної капітули василіанських монастирів у Львові» (копія, 1739 р.). Арк. 1-11.

Information about the author: Stetsyk Y. O.,

Candidate of Historical Sciences, Associate Professor at the Department of Ukraine's History, Ivan Franko Drohobych State Pedagogical University 46, L. Ukrainky St., Drohobych, 82100, Ukraine 


\section{RUSSIAN-UKRAINIAN WAR 2014-2019 YEARS AS THE DECISIVE STAGE OF THE STRUGGLE FOR THE UKRAINIAN INDEPENDENT STATE}

\section{Sytnyk O. M.}

\section{INTRODUCTION}

The overt aggression of the Russian Federation against Ukraine, launched in 2014 , determined the decisive stage of the struggle for the independence of the Ukrainian state. The urgency of this problem is primarily due to the need to form the ideological and political paths for a proper response to hybrid, information-sabotage means and methods of warfare, unleashed by the Kremlin and the search for effective means to counter them. In particular, the task of developing a full-fledged national (state) ideology, which is able to consolidate the nation in the conditions of war and confrontation with an insidious enemy, remains relevant.

Due to the incompleteness of the Ukrainian national liberation struggle of previous eras, and, in particular, the national liberation struggle of 1917-1921, at present the Ukrainian state once again faced the systemic aggression and expansion of the Kremlin regime.

In general, the process of Russian imperial expansion, like the imperial history of Muscovy, in general, has a rather long history, reaches the XII - XIII centuries, but was quite clearly manifested at the turn of the XVII - XVIII centuries.

It should be noted that every aggression of Moscow almost always took place with the expectation of precisely the Ukrainian traitors. The latter usually served as the fifth column of the occupiers and in every way contributed to the interests of the Kremlin.

A number of Ukrainian scientists and thinkers considered the relationship between the Russian and Ukrainian peoples in the context of opposing two types of civilizations - sedentary, agricultural on the one hand, and hunting-nomadic, invasive on the other.

Throughout its history, the Moscow state has shown a predatory nature and a tendency to expand towards its neighboring countries. Especially in relation to such rich as Ukraine. However, for Moscow 
(Russian) colonialism, the seizure of material resources alone was not enough. This was complemented by the absorption of human resources: the most intelligent, socially active and strongly gifted Ukrainians. It was necessary for the endless colonial wars of the Moscow state, which at the turn of the XVII - XVIII centuries transformed into imperial Russia.

Especially for Russians, the cult of war and the seizure of foreign territories was close, regardless of whether or not neighboring Ukraine, Belarus, the Baltic States, the Caucasus, or much further: Siberia, Central Asia, the Far East, and the like.

It should be noted that it is precisely here that the historical origins of the attitude of Russians towards Ukrainian farmers are rooted: for centuries a malicious and envious desire has been formed not only to rob Ukrainians, but also a parasitic desire to squeeze everything possible from them. This trend reached its climax in the first half of the twentieth century under the rule of the Bolsheviks. And now we have a kind of reproduction of the Moscow imperial-totalitarian regime, which is trying to seize Ukraine again at any cost.

\section{Background of the Russian-Ukrainian War of 2014-2019}

Y. Dashkevich noted that when creating their Ukrainian state, Ukrainians should reconsider and clarify their history, based on truth, reliable facts and historical events. Being for centuries under the rule of the conquerors, the Ukrainians were actually deprived of the opportunity to influence the formation of national consciousness and the development of history, with the result that the history of Ukraine was written primarily to please these conquerors ${ }^{1}$. O. Doni suggests that Russia is trying to usurp the history of Ukraine as a springboard for aggression. First, they steal Ukrainian history, then deny the right of Ukrainians to exist as a separate ethnos, then they attack Ukrainian territory ${ }^{2}$. These are, as a rule, the actions of the Russians.

The Moscow state absorbed the aggressive, conquering policy of the Golden Horde. She contrasted the European values with the Messianic ideology of the Third Rome, and then threw herself with Asian fanaticism

\footnotetext{
Дашкевич Я. Як Московія вкрала історію Київської Русі-України. URL: http://uainfo.org/blognews/398664-kak-moskoviya-ukrala-istoriyu-kievskoy-rusi-ukrainy-doklad-doktoraistoricheskih-nauk.html\#sel=8:1,10:45.

${ }^{2}$ Доній О. Диспут 3 росіянами на радіо «Свобода». URL: http://kyiok.com.ua/hromadskist/1153donii-na-rosiiskomu-radio-rozpoviv-chyi-kniaz-volodymyr-video.html.
} 
into the arms of Bolshevism ${ }^{3}$. As in all previous centuries, the goal of the Moscow Horde was primarily not to separate individual territories (now it is the Crimea and Donbass), but to conquer the capital, Kiev. It was also extremely important for Muscovy, despotic in essence, to destroy any hotbeds of democracy, especially if they concerned the veche system, that is, the people's rule.

The formation of the Russian Empire in the XVIIIth century had farreaching political consequences, both for the Russian people and for a number of countries that came under its authority or had a common border with it. The imperial idea became the ideological rationale for the unusual territorial expansion of Russia. Its origins can be traced back to the end of the XVth century. The imperial doctrine that was formed by the leaders of the Orthodox Church and supported by the political elite of the Moscow State became the official ideology of the Russian autocrats. Its practical application demanded enormous material resources and human sacrifices from the government circles of Muscovy. At the same time, it greatly influenced its further ethnopolitical development ${ }^{4}$.

The external manifestations of Moscow imperialism are explained by the aggressive practice of the Moscow tsars and governments. Muscovy needed weapons money, because the neighboring states grew culturally and economically, and consequently, militarily. To increase taxes, the government could not, because there was no longer nothing not taxable, and the old taxes were not enough to fill the treasury. It remained to rob the neighbors. The people of Moscow, on the orders of their tsar, joyfully went to let down, enslave, exploit, rob the neighboring nations. ${ }^{5}$. Through the history of Moscow's expansion in relation to Ukraine and other countries, the entire predatory nature of Russian imperial colonialism was fully manifested, which was NOT abhorred by any mean means to achieve the aggressors' invaders.

Southern Ukraine in the Russian imperial projects was assigned the role of a springboard for the further expansion of the Russian Empire in the Balkans and the Mediterranean. Here it was even planned to build a third,

\footnotetext{
3 Нестайко О. Великі міфи імперії. Втеча від власної ідентичності. 3-е вид. допов. Львів: ЛА «Піраміда», 2008. С. 184.

4 Дашкевич Я. Як Московія вкрала історію Київської Русі-України. URL: http://uainfo.org/ blognews/398664-kak-moskoviya-ukrala-istoriyu-kievskoy-rusi-ukrainy-doklad-doktora-istoricheskihnauk.html\#sel=8:1,10:45.

5 Штепа П. Московство: його походження, зміст, форми й історична тяглість. 9-е вид. Дрогобич: Відродження, 2012. С. 161.
} 
besides Petersburg and Moscow, capital of the Russian Empire. The name «Novorossiya» was better suited to such intentions for the newlyestablished territories. In the case of the implementation of these intentions, this territory from the outskirts of the Russian Empire turned into its center. Changes in the region in terms of its imperial incorporation were aimed at transforming this Ukrainian-Cossack region into Novorossia. Introducing here the «Russian world» (in modern terms), all the cells of Ukrainian life, the remnants of the Cossack territorial structure, the Cossack agrarian structure based on free-labor were destroyed. Instead, imperial despotism was planted ${ }^{6}$.

The Ukrainian nation was massively Russified and denationalized. But, at the same time, the communist Russian empire hypocritically called Ukraine a sovereign republic, actually using all methods of genocide against the Ukrainians ${ }^{7}$. A tough authoritarian power was established by the Communist Bolsheviks after the revolutionary explosion of $1917^{8}$. But the basis of Bolshevism was the former imperial authoritarian-bureaucratic subculture. This «culture» coincided with the ideology of the ruling Communist Party and was constantly used by it as an instrument of a repressive system in suppressing national movements, and above all - the Ukrainian people 9 . At the same time, Bolshevism was a combination of Marxism, Leninism and Russian imperialism, characterized by elements of Russian fascism and chauvinism ${ }^{10}$. Therefore, the ideology of Bolshevism permeated the desire for power and the possession of as many resources as possible, regardless of what kind of people they belong to.

$\mathrm{V}$. Vasilenko, considering the genesis and nature of the war of Russia against Ukraine, noted that the armed attack of the Russian Federation on Ukraine was unexpected both for the Ukrainian politician and the public, and for the international community. However, objectively the war was caused by the imperatives of Ukrainian politics in Russia. The outstanding military theorist Karl von Clausewitz in his classic work "On War", the fundamental tenets of which are relevant today, wrote: "War is the

\footnotetext{
6 Турченко Г. Ф. Історична наука і сучасна гібридна війна Росії проти України. Наукові працฺі історичного факультету Запорізького національного університету. Вип. 46. 2016. С. 297, 298.

7 Лук'яненко Л. У листопадові жалобні дні. Кому був вигідний голодомор? К.: МАУП, 2004. С. 50, 51.

${ }^{8}$ Попович М. В. Міфологія в суспільній свідомості посткомуністичної України. Дух і літера. 1998. № 3-4. К.: Сфера, 1998. С. 64.

9 Білас І. Г. Репресивно-каральна система в Україні. 1917-1953: Суспільно-політичний та історико-правовий аналіз: у 2 кн. К.: Либідь-Військо України, 1994. Кн. 1. С. 14.

${ }^{10}$ Галамай С. П. Боротьба за визволення України. 1929-1989. Львів: Каменяр, 1993. С. 63, 64.
} 
continuation of politics by other means". So, at one time, in December 1917, the Ukrainian policy of the government of Soviet Russia ruled by Lenin led to the declaration of war to the Ukrainian People's Republic. The consequence of that war, which ended in the fall of 1920, was the forceful way of planting the communist regime in Ukraine and incorporating it into the USSR. Since then, any form of the Ukrainian national liberation movement - the demands of cultural autonomy, the armed struggle of the UPA - Soviet Russia resolutely suppressed, and its participants severely punished. In the past, Ukraine became the engine of transformation of the Moscow kingdom into an empire and was its powerful spiritual, cultural and resource donor. Having annexed the territory of Ukraine, the Moscow kingdom expanded its borders to the borders of Eastern Europe, and subsequently proclaimed itself an empire, appropriated the ancient name of Ukraine - Russia - and the entire history of Ukraine-Russia, including the ancient Russian statehood. Owing to such a special role of our country in the history of Russia, the restoration of the independent statehood of Ukraine in August 1991 became a challenge to the Russian imperial consciousness and psychologically traumatizes the modern Russian imperial chauvinists. The revival of Ukraine's independence is inevitably associated with the restoration of its national memory and an isolated national history and, accordingly, makes the history of Russia curtailed, destroys the myth of millennial statehood, European identity and the supposedly original and natural affiliation of the latter to the European civilization space. Therefore, the Russian imperial chauvinists understand that without the return of Ukraine (with its territories, resources and human potential) to the bosom of Russia, any attempts to restore its imperial status are unpromising. Considering this, the Russian political elite and ordinary citizens are mostly convinced that: Russians and Ukrainians are one people, their reunion in one state should end with the formation of a powerful ethnic group and the formation of a "Russian world" with one church, one language and one culture; Ukraine is part of Russia and should not exist separately from it; Ukraine must in the disintegration of the Soviet empire and the problems of Russia caused by it; Ukraine's independent statehood is a geopolitical anomaly and represents a strategic threat to Russia; Russia without Ukraine is geopolitically incomplete and cannot be reborn as a world superpower. The anti-Ukrainian ideologems and revanchist aspirations rooted in the Russian mentality determine the 
content of Russia's foreign policy towards Ukraine and its ultimate strategic goal, which provides for the total destruction of the latter as a national unit, subject of international law and geopolitical reality ${ }^{11}$.

According to V.P. Gorbulin, the starting point for the formation of a hybrid world pattern was Russia's aggression against Ukraine. And this is not an estimate in the spirit of a romantic Ukrainian-centrism - this is an objective state of the question. As the Sarajevo murder freed up a compressed spring of deep contradictions and complex processes that led to the First World War, so the direct annexation of Crimea by Russia and its impact on the Donbass became the same trigger for the start of a new world hybrid war. It should be noted that, of course, "hybrid war" is a phenomenon of the XXI century. But in the history of Russian-Ukrainian relations, some of their techniques were used before. In 1917-1921, many of these methods were already used by Bolshevik Russia in the struggle against Ukraine. This was the response of the former imperial metropolis to the Ukrainian attempt to defend its independence, proclaimed in January 1918 by the Central Rada. Ukraine did not want the Bolshevik dictatorship, the destruction of democratic freedoms, the "red terror" and the return to the control of Russia, now Bolshevik. In response, regular troops went to Ukraine from Russia under the red flag of the communist revolution and the fake slogan of "helping the fraternal people in the struggle against the world bourgeoisie". They were helped in every way by the local "fifth column" of the Bolsheviks and other pro-Russian elements who were particularly active in the southern and eastern regions of Ukraine. Then Ukraine lost its independence for many decades ${ }^{12}$.

For several decades, the Bolsheviks and their followers, the communists and neo-communists, weaned people to solve problems on their own, to think and take responsibility. But they taught that the "wise" leadership will decide everything for us. And as a result: we have what we have done with our inaction or indifference. And this is especially clearly seen in the example of Donbass. The population of the latter, for the most part, in 1991 voted for the independence of Ukraine. But the hopes that were placed on this perspective were not justified. Those residents of the region who saw independence of Ukraine, above all - economic

\footnotetext{
${ }^{11}$ Василенко В. Війна 2014 року: спроба системного аналізу. Украӥнський тиждень. 2014. № 42. Спецвипуск. С. 28, 29.

12 Турченко Ф. Проект «Новоросія» і новітня російсько-українська війна. К.: Інститут історії України НАН України, 2015. С. 146.
} 
independence, already in the early 1990s faced a whole range of socioeconomic problems, and for those citizens who sought, above all, political independence and Ukrainization, the realities turned out to be delicates from the desired result. At the same time, the Kiev authorities practically withdrew from the solution of cultural and national problems of the region, while for local authorities, pro-Ukrainian sentiments remained alien and unacceptable.

Despite the intensive imitation of democratic reforms in Russia during the 1990s, a democratic society did not form there. Moreover, throughout all this time, the Russian state has preserved the tradition of despotic authoritarianism and scornful attitude towards fellow citizens inherited by centuries. The Bolshevik organs of violence and terror (the "Cheka"-DPUNKVD-MGB-KGB) led this tradition to the extreme forms of the destruction of both our own and neighboring peoples.

L. Harding noted that Putin, having replaced B. Yeltsin in 2000, quickly created a transformed post-Soviet Russia. The FSB has become the dominant authority in the country - a huge secret organization with unlimited resources, which operates outside the law in accordance with its own set of rules (also secret) ${ }^{13}$. In fact, the FSB became the successor to the KGB, having overrun most of the methods of the latter, inherent to the NKVD - dressing up in the Ukrainian military, vile use of civilians, and the like.

The transformation of the KGB into the FSB led only to a more cynically refined preservation of this criminal system, and Putin's creature when replacing Yeltsin has every reason to be considered not just unsuccessful, and moreover destructive for many thousands of Ukrainian and Russian, and ultimately for the most historical the fate of Russia.

The system of state power in the Soviet Union was of a criminal nature. This is evidenced by many facts, in particular, that on the orders of Stalin in the Soviet Union, random innocent people were often shot according to plan and quotas, including children from twelve years old. The mimicry of the Moscow authoritarian regime led to the formation of an unusually unique form of the vile, deceitful and cowardly (proclaiming as the enemy number 1 - the United States, he does not fight with him, but mostly destroys Russians in Eastern Ukraine) of fascism.

13 Гардінг Л. Мафіозна держава. Як один репортер став ворогом брутальної нової Росії. К.: Темпора, 2014. С. 20. 
Constant views on the revolutionary changes in Russia, the belief that national problems can be solved within the framework of a single allRussian revolutionary-democratic front led to the loss of the chance that gave Ukrainians the opportunity to create their own independent state. All this not only led to the defeat of the national liberation struggle of 1917-1921, but also led to the further total destruction of the Ukrainians throughout the existence of the Bolshevik government.

\section{Specificity of the Russian-Ukrainian War of 2014-2019 in the Context of the Struggle for the Ukrainian Independent State}

The modern Russian-Ukrainian war has become a natural consequence and continuation of the centuries-old expansion of the Moscow state, with its imperial creations: autocracy, Bolshevism and Putinism with neoshovinism against Ukraine. Already at the beginning of the XXI century, we were faced with the resuscitation of neo-Bolshevism in the form of authoritarian tendencies in modern Russia, the main thing in the Putin regime.

According to F. Turchenko and G. Turchenko, not only the revolution of 1917-1921, but also the revolution of 1991 turned out to be incomplete. After all, post-Soviet Russia did not abandon its imperial ambitions, and without complete control over Ukraine, the restoration of the empire is impossible. The idea of reviving historical New Russia under the flags of the "Russian world" was chosen as one of the instruments of this ${ }^{14}$.

History tends to repeat. Especially - in cases when a certain people or a nation does not draw proper conclusions regarding errors and omissions. First of all, it concerns the events of 1917-1921, when, being in a peculiar bifurcation point, after centuries of statelessness, which was at the same time a result of the disunity and fragmentation of Ukrainians, Ukraine received a unique chance of independence. However, due to a number of objective and subjective circumstances, this could not be achieved by the Ukrainians. And how payback is terror, famine and total annihilation by Moscow invaders of the most conscious representatives of our nation, including modern aggression. The modern modern imperial policy of the Kremlin is the implementation of the methods of autocracy and

14 Турченко Ф. Проект «Новоросія» і новітня російсько-українська війна. К.: Інститут історії України НАН України, 2015. С. 130, 179. 
Bolshevism, with a combination of criminal oligarchic and sabotage and terrorist forms ${ }^{15}$.

The heiress of the Russian Empire - the Russian Federation is now actively pursuing an expansionist policy, promoting and aggressively spreading the ideas of the so-called "Russian world". The short-sighted, haphazard and treacherous policy of the previous Ukrainian government in the humanitarian, ethnonational and informational sphere, and sometimes direct connivance on the part of some officials to spread these ideas, led to the fact that Russian chauvinistic ideas were fixed in the mass consciousness of the population of the southern and eastern regions, allowed carry out the criminal annexation of the Crimea and spread separatist sentiments in the east of the country with the support of a certain part of the local population axis to unite with the "big Russia". Russia's support of the armed conflict in the east of Ukraine and its direct entry into the war against Ukraine showed the depth of immorality and crime of the Russian authorities, who for the sake of spreading their ideas and reviving the Great Russian Empire are capable of violating international legal norms, violating their own international obligations, using the most disgraceful and terrorist criminal methods of propaganda and war - open lies, distortion of facts, even bloodshed, the use of hostages among the world mass population, mass terror and torture of prisoners and the like ${ }^{16}$.

It is well known that the Russian-Ukrainian war of 2014-2019 has a hybrid, information-sabotage character. During the annexation of the Crimea - the seizure by the Russian special services (under the guise of "unknown persons") of government buildings in Simferopol and the removal from power of the leadership of the ARC; the deployment in the Crimea of the so-called self-defense detachments ("green men"), who took control of the power structures of the Crimean peninsula and the key objects of its infrastructure, blocked the units of the power structures of Ukraine on the territory of the Autonomous Republic of Crimea; the introduction of Russian troops in the Crimea under the guise of military exercises and under the guise of the relevant articles of the Agreement on the conditions of the stay of the

15 Ситник О. Донцовська візія національно-визвольних змагань у контексті російсько-української війни 2014-2016 років. Треті Бандерівські читання. «Візія Української держави в ідеології українського націоналізму» : збірник матеріалів, м. Київ, 3 лютого 2016 р. Київ-Івано-Франківськ: Місто НВ, 2016. C. 180,181 .

16 Гай-Нижник П. (керівник проекту, упоряд. і наук. ред.). Формування загальнонаціональної ідентичності українців в контексті сучасних викликів. Агресія Росії проти України: історичні передумови та сучасні виклики. К.: «МП Леся», 2016. С. 50. 
Black Sea Fleet of the Russian Federation on the territory of Ukraine; "Legalization" of the fact of occupation of the Crimea by holding a "referendum" on the status of the Autonomous Republic of Crimea, as well as the adoption of relevant decisions by the Parliament and the President of the Russian Federation on the inclusion of Crimea to Russia as a subject of the Russian Federation; the liquidation of the Ukrainian authorities in the Crimea, as well as the ousting of Ukrainian troops from the territory of the Crimean peninsula. Thus, Russia annexed the Crimea and created "foundations" for its integration into the Russian Federation. At the same time, the Russian annexation of the Crimea was not recognized by the overwhelming majority of countries and caused a negative reaction from the US, the EU and their partners, who imposed sanctions against Russia.

When creating the so-called "Novorossiya" and solving the armed conflict in the east of Ukraine, the following factors of hybrid war took place: destabilization of the eastern and southern regions of Ukraine by organizing mass anti-power protest actions, clashes with law enforcement agencies and supporters of the unity of Ukraine, as well as seizing administrative buildings; implementation of the "Crimean" scenario in the Donetsk and Luhansk regions, including the establishment of control over part of their territories, the creation of "militia groups" from among the representatives of the Russian special services, criminalized law enforcement agencies and local pro-Russian forces; "Legalization" of the so-called Donetsk and Lugansk People's Republics (DPR and LPR) by means of holding corresponding "referendums", as well as "elections" of their "authorities"; Russia's full support to the separatists, including financing their activities, training militants and supplying them with weapons, military equipment and ammunition, as well as the introduction of Russian troops into the territory of the DPR and LPR; the implementation by the Russian Federation of political and economic pressure on Ukraine, as well as the buildup of a group of armed forces of the Russian Federation near the Ukrainian border; discrediting the military operation of Ukraine against the Russian-terrorist groups and the disintegration of the country, attempts to submit this operation as "punitive against its own population" "17. All this showed quite significant preparation of the Russian Federation for complex aggression.

17 Марчук Е. Девять реалий о гибридной войне в Донбассе. URL: http://news.liga.net/news/ politics/12867318-marchuk_devyat_realiy_o_gibridnoy_voyne_v_donbasse.htmhttp://gazeta.dt.ua/internal/ gibridna-viyna-yak-klyuchoviy-instrument-rosiyskoyi-geostrategiyi-revanshu-_.html. 
V. Gorbulin believes that the West, for its part, in essence, "washing its hands", allowed aggression on the part of the Russian Federation. Western analysts, in particular Peter Dickinson, are speaking more and more about this in their material for the Atlantic Council. He notes that most of the Western media immediately after the Russian aggression against Ukraine unexpectedly "blind" as to who was the aggressor in the Ukrainian conflict and how the occupation forces should be named, inventing some new words and phrases in return, the only meaning of which is not to call the Russian such an aggression ${ }^{18}$.

The current Russian-Ukrainian war belongs to this type of armed conflict, which is called "hybrid", "non-linear", "non-conventional". In the course of wars of this type, various methods of fighting the enemy are used. In general, the characteristic features of hybrid wars are as follows: aggression without an official declaration of war; concealment by the aggressor country of its participation in the conflict; "Information war" propaganda and counter-propaganda with the use of "dirty" information technologies; widespread use of the "fifth column" and irregular armed formations (including under the guise of the civilian population), the disregard of the aggressor by international standards of warfare, existing agreements and new agreements; political and economic pressure measures; confrontation in cyberspace and the like ${ }^{19}$.

Most international military experts recognize that there is a threat of new conflicts in Europe, and Russia's aggression threatens the security of not only Ukraine, but the whole of Europe. In a hybrid war in its own territory it is difficult to win, because it has no boundaries. Therefore, it is this factor that has influenced the miscalculations of the Ukrainian authorities in the conduct of the anti-terrorist operation. The RussianUkrainian border cannot be closed if Ukraine does not control the information space and the air of the East of Ukraine. At the same time, the terrorists will continue to carry out provocations on the border and seized territories with the information support of the Russian mass media. The network actions of terrorists in the occupied territory, together with the support of the Russian troops on the border, will constantly allow Russia to continue supplying weapons and ammunition to terrorists. Therefore, until

\footnotetext{
18 Горбулін В. Хитромудра невизначеність нового світопорядку. URL: http://gazeta.dt.ua/internal/ hitromudra-neviznachenist-novogo-svitoporyadku-_.html.

19 Турченко Ф. Проект «Новоросія» і новітня російсько-українська війна. К.: Інститут історії України НАН України, 2015. С. 143.
} 
the information space in the Donbas is controlled by Ukraine, Ukraine will not be able to count on the support of its own population in the conflict region. This situation will contribute to the formation of a permanent social base of terrorists of the LPR and the DPR ${ }^{20}$.

Virtually the entire history of the Ukrainian liberation movement of the twentieth century was aimed at creating a Ukrainian independent conciliar state. And an important guarantee of this was the massive support of the Ukrainian nation ${ }^{21}$. The modern Russian-Ukrainian war, like the preceding Revolution of Dignity, has led to a number of challenges. First of all, it concerns the readiness of Ukrainians to defend their nation and state. At the same time, the fact that the part of Russians joined the defense of the independence of Ukraine became important ${ }^{22}$. Awareness of involvement in these events also contributed to the understanding by representatives of other nations that the aggression of the Russian Federation can be directed not only against Ukraine, but also against their states. It is recognition of the duty of protecting our own state priorities and honoring national values can give Ukrainians a chance to defend their state and preserve national dignity ${ }^{23}$.

During the entire period of independent Ukraine, problems with the formation of civil society in the country constantly made themselves felt. In part, this was due to the traditional individualism of Ukrainians. But to a large extent it was the result of the existence of a post-totalitarian inheritance, with people's subconscious fear towards the authorities and power structures, civic infantilism and the like. At the same time, each time the manifestations of discrimination of the rights of citizens in: 1990-1991, 2004 and 2013-2014, - led to civil outrage, which resulted, among other things, were Orange Maidan and the Revolution of Dignity. These events were also the result of the creative rise of the Ukrainian nation and the result of the Spirit's action - not just as a transcendental factor, but rather a concrete phenomenon, which often inspires ethnic Russians and representatives of other nations living in Ukraine. And

20 Дацюк С. А. Стратегія перемоги України у війні з Росією. URL: http://blogs.pravda.com.ua/ authors/datsuk/53a5542ba2a4a/.

${ }^{21}$ Ільницький В. Основні форми співпраці українського визвольного руху з різними соціальними групами населення у Карпатському краї ОУН. Східноєвропейський історичний вісник. № 2. 2017. С. 65.

22 Ситник О. Історичні витоки російсько-української війни 2014-2017 років. Східноєвропейський історичний вісник. № 2. 2017. С. 79, 80 .

23 Ситник О. М. Парадигма української націоналістичної ідеології в контексті національновизвольної боротьби першої половини XX-го та початку XXI-го століть. (Л. Тимошенко, Ред.). Дрогобицький краєзнавчий збірник. 2015. Спецвипуск II. С. 355, 356. 
precisely because of this Spirit, there were always forces to resist the invader-occupier, the most vivid examples of which, for example, in the twentieth century were: the Kholodnoyarskaya Republic, the UPA army, and, as their original reproduction, the modern movement of volunteers and volunteers.

The modern war for the independence of Ukraine in the form of a hybrid version of the information-sabotage war is primarily a war of ideologies. For our country, the main ideological problem of this war is the rejection of the remnants of Sovietness, and for Putin's Russia it is a weak reanimation of the USSR, with all its ideological and political attributes and symbols. Many did not expect this war, but why only Putin's longterm and annoying appeal to the ideological dogmas of the Soviet Union is worth it. At the same time, in modern Russia - this country of the absurd, there are attempts to combine deliberately incompatible and contradictory things (communism and Russian nationalism, etc.).

Calling Ukraine's southeast in the spring of 2014 Novorossia, Putin showed not only his own incompetence in history, a cynical disregard for the foundations of international law and a perverted view of the world order. Clearly, he and his Kholuy entourage were motivated by the desire to see Ukraine within the framework of the former colony - both in tsarist times, in fact and in Soviet times, and to a certain extent - even in the period of independence. After all, from the very beginning of gaining state independence, our country, primarily because of the ideological and political dependence on the Kremlin of various figures such as Ivashko, Kravchuk, Kuchma, Yanukovich, etc., could not really get rid of the imperial shackles of Moscow. At the same time, all this time, even to this day, the ideological oppression of the Moscow Patriarchate over Ukraine. But in Ukraine, the state ideology has not yet been formed, which should protect the interests of the state, in particular - ideologically and politically.

Putin's fanatical obsession with resuscitation of the Russian imperial ideal and the ideology of the USSR led to the fact that on the way to the realization of these manic whims, he is ready to go for any restrictions and sufferings even for his own people. In fact, during the reign of Putin, he could not solve a single problem in the country for further socio-economic and cultural development, as a result of which Russia is degrading, the population is dying out. This country has become a raw materials appendage that eats away its natural resources, its vast territories are falling 
into neglect, but the Kremlin's priority is the traditional course aimed at restoring the Russian imperial system and spreading it to the whole world. The obsession with which Putin is implementing this course overshadows all other problems that are ignored and sacrificed in order to achieve relevant imperial goals. Nevertheless, his power rests on the support of the masses. This is because Putin indulges the low instincts of the Russian people, turning them into a crowd, using and fueling chauvinism, imperialism, great power, the thirst for revenge for the defeat in the Cold War and the collapse of the USSR. Therefore, Ukrainian political analysts accurately described Putin's policy as rashism, that is, a type of modern Russian fascism and Nazism, rightly revealing parallels between Putin and Hitler. In order to preserve his power against the background of modest achievements in Russia's socio-economic and cultural development, Putin, in order to support his popularity, must constantly find enemies and fight them. To maintain power and implement his adventurous foreign policy, Putin must always maintain a tense situation in his country and in the world, resorting to appropriate destructive actions ${ }^{24}$.

In general, it should be summarized that our historical experience convinces us that in developing the Ukrainian state strategy it is necessary to change and restructure its basic principles, namely: in the formation of social ideology, it is necessary to get rid of the pacifist philosopher categorically; the nation should be brought up on the principles of national heroism, the priority of state and national interests; it is necessary to abandon the illusionary vision of international relations and firmly apply the logic of geopolitics, according to which Ukraine, as a state located in the geostrategic zone, cannot afford to relax militarily and conduct deceptive pacifist international policy, not to react to threats from imperial tendencies, above all Russia; Russian imperialism is chauvinistic, and therefore it is especially aggressive to those nations that defend their own identity and independence.

During the centuries-old history of Moscow expansion with respect to Ukraine and other countries, the entire predatory nature of Russian imperial colonialism was fully manifested, which was not disdained by any vile means to achieve the aggressor's own objectives. The current trend testified to the loyalty of the Russian monarchy even to seemingly

\footnotetext{
${ }^{24}$ Пасічник В. Російська загроза незалежності та державному суверенітету України: зміст та духовні детермінанти. URL: http://preobrazhennja.org.ua/content/rosijska-zagroza-nezalezhnosti-ta-derzhavnomusuverenitetu-ukrayiny-zmist-ta-duhovni-determi.
} 
progressive and patriotic-minded Ukrainian thinkers. The process was not only physical entry into the Russian Empire. But, more importantly, the ideological, political and moral-psychological introduction to imperial practice.

It should also be noted that modern wars and military-political conflicts have significant differences from previous models. At the same time, during world history, especially the twentieth century, quite a lot of wars had signs of a hybrid and information-sabotage character. Now, most wars are not only armed in military terms, they often have a close connection with the psychological impact on people's minds through agitation, propaganda and other means of influence. This is especially true of the modern hybrid war unleashed by the Kremlin against Ukraine.

Currently, active opposition of Ukraine to actions by the Russian Federation, including with the use of military force, did not allow to fully implement the "Crimean" scenario in the east of our country. In fact, the hybrid war of Russia against Ukraine turned into an armed conflict between the two countries with the direct involvement of troops from both sides. At the same time, despite the attempts of the Russian side to hide the participation of its armed forces in the actual war, this fact was recognized by the overwhelming majority of the world community, which led to the strengthening of the US and EU sanctions against Russia.

In order to properly repel the hybrid, information-sabotage means of war that the enemy is waging against Ukraine, we need to consider the following:

- the nation should be brought up on the principles of national heroism, the priority of state and national interests;

- since with the development of civilization processes and the advent of globalism, the forms and types of interethnic, interstate confrontations expanded and became more diverse, it became possible to use open and closed methods of attack and sabotage in a war with a rival, and at the same time making information "only political interference" through informational attacks "In the internal affairs of the victim country, or by the appearance of "civil conflict in it";

- Russian imperialism has a chauvinistic essence, and therefore it is especially aggressive towards nations, ignoring the "leading role" and "mission" of the Russian nation and state; it is clear that in this case the Ukrainian nation and state are under the brunt of Russian expansionism 
and chauvinism, because they carry the main challenges of the Russian imperial identity: they "take" the historical heritage and culture of the past (before the XVII century) from Russians, break a large number of Russian great-power myths, such as the "fraternal peoples", the "civilizational role" of the Russian empire, the "justification" of Russian communism, etc., deprive the empire of its geopolitical scope, for it cuts off its stratum This is an important part of the Black Sea region, therefore, Ukraine's foreign policy should be as thoughtful and balanced as possible in relation to the Russian state and rationally adequate in relation to its threats.

\section{SUMMARY}

An attempt was made to examine the Russian-Ukrainian war of 2014-2019 through the prism of the struggle for a Ukrainian independent state. Attention is focused on the incompleteness of the Ukrainian national liberation struggle of previous eras, and in particular the national liberation struggle of 1917-1921. This is especially relevant, since now the Ukrainian state, once again, in the early twentieth century, faced with the manifestations of systemic aggression and expansion of the Kremlin regime. It was noted that outright aggression of the Russian Federation against Ukraine, launched in 2014, led to the decisive stage of the struggle for the independence of the Ukrainian state. It was emphasized that the importance of this topic is due to the need to form ideological and political ways of a proper response to hybrid, information-sabotage means and methods of warfare, unleashed by the Kremlin and the search for effective means to counter them. It is noted that the modern occupation policy of Moscow has created a number of problems, primarily of an ideological nature, given the need to overcome the remnants of Sovietism and totalitarian symbols. It is also indicated that every aggression of Moscow almost always took place with the expectation of precisely Ukrainian traitors. The latter usually served as the fifth column of the occupiers and in every way contributed to the interests of the Kremlin.

Key words: Russian-Ukrainian war, Ukraine, the struggle for an independent state, aggression of the Russian Federation, hybrid war, information-sabotage means of warfare, ideology. 


\section{REFERENCES}

1. Дашкевич Я. Як Московія вкрала історію Київської РусіУкраїни. URL: http://uainfo.org/blognews/398664-kak-moskoviya-ukralaistoriyu-kievskoy-rusi-ukrainy-doklad-doktora-istoricheskihnauk.html\#sel=8:1,10:45.

2. Доній O. Диспут 3 росіянами на радіо «Свобода». URL: http://kyiok.com.ua/hromadskist/1153-donii-na-rosiiskomu-radiorozpoviv-chyi-kniaz-volodymyr-video.html.

3. Нестайко О. Великі міфи імперії. Втеча від власної ідентичності. 3-е вид. допов.. Львів: ЛА «Піраміда», 2008. 186 с.

4. Штепа П. Московство: його походження, зміст, форми й історична тяглість. 9-е вид.. Дрогобич: Відродження, 2012. 412 с.

5. Турченко Г. Ф. Історична наука і сучасна гібридна війна Росії проти України. Наукові праці історичного факультету Запорізького національного університету. Вип. 46. 2016. С. 295-301.

6. Марченя П., Разин С. Империя и смута - инварианты российской истории. URL: http://www.nivestnik.ru/phpbb3/ viewtopic.php?f=8\&t=1292.

7. Лук'яненко Л. У листопадові жалобні дні. Кому був вигідний голодомор? К.: МАУП, 2004. С. 40-54.

8. Попович М. В. Міфологія в суспільній свідомості посткомуністичної України. Дух $і$ літера. 1998. № 3-4. К.: Сфера, 1998. C. 57-68.

9. Білас І. Г. Репресивно-каральна система в Україні. 1917-1953: Суспільно-політичний та історико-правовий аналіз: у 2 кн. К.: ЛибідьВійсько України, 1994. Кн. 1. 432 с.

10. Галамай С. П. Боротьба за визволення України. 1929-1989. Львів: Каменяр, 1993. 343 с.

11. Василенко В. Війна 2014 року: спроба системного аналізу. Український тиждень. 2014. № 42. Спецвипуск. С. 27-42.

12. Турченко Ф. Проект «Новоросія» i новітня російськоукраїнська війна. К.: Інститут історії України НАН України, 2015. $166 \mathrm{c.}$

13. Гардінг Л. Мафіозна держава. Як один репортер став ворогом брутальної нової Росії. К.: Темпора, 2014. 432 с.

14. Ситник О. Донцовська візія національно-визвольних змагань у контексті російсько-української війни 2014-2016 років. Треті Бандерівські читання. «Візія Української держави в ідеології 
українського націоналізму» : збірник матеріалів, м. Київ, 3 лютого 2016 р. Київ-Івано-Франківськ: Місто НВ, 2016. С. 169-181.

15. Гай-Нижник П. (керівник проекту, упоряд. і наук. ред.). Формування загальнонаціональної ідентичності українців в контексті сучасних викликів. Агресія Росії проти України: історичні передумови та сучасні виклики. К.: «МП Леся», 2016. С. 32-54.

16. Марчук Е. Девять реалий о гибридной войне в Донбассе. URL: http://news.liga.net/news/politics/12867318-marchuk_devyat_realiy_o_ gibridnoy_voyne_v_donbasse.htmhttp://gazeta.dt.ua/internal/gibridnaviyna-yak-klyuchoviy-instrument-rosiyskoyi-geostrategiyi-revanshu-_.html.

17. Горбулін В. Хитромудра невизначеність нового світопорядку. URL: $\quad$ http://gazeta.dt.ua/internal/hitromudra-neviznachenist-novogosvitoporyadku-_.html.

18. Дацюк С. А. Стратегія перемоги України у війні з Росією. URL: http://blogs.pravda.com.ua/authors/datsuk/53a5542ba2a4a/.

19. Ільницький В. Основні форми співпраці українського визвольного руху з різними соціальними групами населення у Карпатському краї ОУН. Східноєвропейський історичний вісник. 2017. № 2. C. 64-70.

20. Ситник О. Історичні витоки російсько-української війни 2014-2017 років. Східноєвропейський історичний вісник. 2017. № 2. C. $71-81$.

21. Ситник О.М. Парадигма української націоналістичної ідеології в контексті національно-визвольної боротьби першої половини XX-го та початку XXI-го століть. (Л. Тимошенко, Ред.). Дрогобииький краєзнавчий збірник. 2015. Спецвипуск II. С. 348-357.

22. Пасічник В. Російська загроза незалежності та державному суверенітету України: зміст та духовні детермінанти. URL: http://preobrazhennja.org.ua/content/rosijska-zagroza-nezalezhnosti-taderzhavnomu-suverenitetu-ukrayiny-zmist-ta-duhovni-determi.

\section{Information about the author: Sytnyk O. M.,} Doctor of Historical Sciences, Associate Professor, Head of the Department of History, archeology and philosophy, Bogdan Khmelnytskyi Melitopol state pedagogical University 41/7, Universitetskaya St., Melitopol, 72312, Ukraine 


\title{
PERCEPTION OF MYKHAILO HRUSHEVSKY'S WORKS DURING INTERWAR PERIOD
}

\author{
Telvak V. P.
}

\section{INTRODUCTION}

Perception of M. Hrushevsky's works by his colleagues from Slavic world has been in the focus of special historiographical interest for a long time. The Czech contribution to this intellectual reflection is not an exception. Let us recall the most thorough modern work of Vitaliy Telvak ${ }^{1}$. The researcher concentrates of the most prolific period of Czech Hrushevsky studies of the last years XIX - the beginning of XX century when the Ukrainian intellectual was at the peak of his scientific activity, actively responding to polemic remarks of his colleagues from the banks of Vltava. Regarding such a chronological accent, the after-war period, when Hrushevsky was in search for possibilities of creative self-realization in emigration and when he later put titanic efforts into the renewal of academic Ukrainian studies in the Motherland, often is outside scientists' focus. As it will be demonstrated below, the mentioned years 1920-1930, though were less marked by research reflection, but had a unique historiographical character, defined by the rapid change of social-political situation. The above-mentioned years are also important because of the establishment of Chech independent Slavic tradition, that did not imposed almost traditional remarks concerning Hrushevsky's unconventional hypotheses, peculiar for previous imperial era.

\section{The Last Decade}

Numerous difficulties of economic and personal character in the organization of scientific work that M. Hrushevsky faced in emigration, pushed him to the idea of returning to Ukraine, where the Soviet government had already firmly established. Thus, when the Kyiv Communists, aiming at splitting Ukrainian emigration in Western Europe, offered M. Hrushevsky the title of academician and provided guarantees of

\footnotetext{
1 Тельвак В. Чеська грушевськіана першої третини XX століття. Iсторіографічні дослідження $в$ Україні. 2008. Випуск 19. Ст. 240-258.
} 
personal security, he decided to return to Ukraine in March 1924. Having certain hopes, he depicted in a letter to J. Bidlo his plans for the future: "I have broad and heterogeneous scientific plans: I would like to continue the history of Ukraine and the history of literature, organize publishing of sources and scientific journal: I do not know which project would succeed. In any case I will let you know"2.

Those were significant results in the scientific and organizational work of a newly elected academician of the Ukrainian Academy of Sciences (hereinafter - UAS) that attracted one more time the attention of the Czech researchers. Especially the Czech colleagues were impressed how "Nestor of Ukrainian history", as he was referred to by one of the Czech observers, established a wide publishing activity, which quickly brought visible consequences.

The Czech observers were contented with the restoration of M. Hrushevsky's magazine "Ukraine" - according to their unanimous assessment - the most outstanding of the Ukrainian studies. For example, in reviewing the first issues of the revived "Ukraine", J. Bidlo drew attention to the difficult conditions in which the Ukrainian scientist had to realize his creative plans in the Soviet state. Therefore, the peer-reviewed publication is believed by the Czech observer to be a clear testimony to M. Hrushevsky's thorough organizational talent ${ }^{3}$. The lively interest of the Czech observers was caused by the publication of materials dedicated to prominent figures of Ukrainian culture in the nineteenth and early twentieth centuries: Mykhailo Maksymovich, Mykola Kostomarov, Olexander Lazarevsky, Panteleimon Kulish and Volodymyr Antonovich ${ }^{4}$.

With considerable interest, the Czech Slavists also followed the appearance of other periodicals edited by M. Hrushevsky. Among them, the Czech colleagues focused on the collection "In 100 Years", devoted to the publication of sources about the Ukrainian modernist revival of the nineteenth century. Several reviews highlighted the high professional level of the publication, the importance of materials published in it for the knowledge of the important era of the Ukrainian past ${ }^{5}$.

\footnotetext{
${ }^{2}$ Чеські адресати Михайла Грушевського. Хроніка-2000. 1999. Вип. 29-30. Ст. 20-25.

${ }^{3}$ Bidlo J. [Review] Ukraina, naukovyj tr’òchmisjačnyk ukrainoznavstva za rok 1924. Časopis národního musea. 1925. Roč. XCIX. S. 83-87.

${ }^{4}$ Charvat V. Časopisy. Slovanský Přehled. 1926. XVIII. S. 481-482; Zpràvy. Českỳ Časopis Historickỳ. 1927. Roč. XXXIII. S. 677; Charvat V. [Review] Україна. Науковий двохмісячник. Slovanský Přehled. 1927. Roč. XIX. S. 72-73.
}

${ }^{5}$ Z. Hájek Zpràvy. Českỳ Časopis Historickỳ. 1929. Roč. XXXV. S. 224. 
Particular attention was paid to the contributions of M. Hrushevsky to the investigations of the Czech-Ukrainian cultural relations. The scholar's "Influences of the Czech national movement of XV century on Ukrainian life and culture, as a problem of experimentation. A few notes", which was prepared by the author during the work on the fifth volume of "History of Ukrainian Literature" was especially warmly accepted by Czech critics ${ }^{6}$. Its content was introduced to readers of the magazine "Slovanský Přehled" by a well-known journalist and politician Vincent Charvat. First of all, he stressed at the importance of the appearance of "this short but extremely interesting studio of the most prominent Ukrainian historian, since Hrushevsky's more voluminous work is inaccessible to wider circles of the Ukrainian and Slavic public"". A Ukrainian researcher provided a significant amount of material about the Czech influence in Ukraine and Belarus in the 14th and 15th centuries, as well as systematized views of Polish, Russian and Ukrainian scholars on this issue and "clearly, briefly described the penetration of the Czech culture to the Eastern Europe in the late XIV and early XV century where it was significantly spread in the Polish administrative and church circles".

The Czech critics met the continuation of M. Hrushevsky's work on "The History of Ukraine-Rus" with numerous reviews. On the pages of the Prague "Časopis národního musea", the two parts of the ninth volume were immediately reviewed by a long-time friend of Ukrainian scientist J. Bidlo. Describing M. Hrushevsky as "the indefatigable and fruitful creator of modern historiography (and to a large extent revolutionary history) of Ukraine or, better, of the Ukrainian people", the reviewer emphasized at the importance of continuing the astonishing scientific activity after returning from emigration. Writing for the Czech reader about the tirelessness of the Ukrainian colleague, the reviewer noted: "The IX volume of his "History of Ukraine-Rus" is fascinating, which is not the only result of his efforts and creativity during those several (7-8) years when he firmly settled in "Soviet" Ukraine. In 1923 he already began publishing a new original "History of Ukrainian Literature", and from 1926 he published 5 volumes, giving a new understanding and description of literary development, and at the same time he was editing several very

\footnotetext{
${ }^{6}$ Грушевський М. Впливи чеського національного руху XIV-XV вв. в українськім життю i творчості, як проблема досліду. Кілька заміток і дезидерат. Записки НТШ. 1925. T. CLI-CLIII. CT. 1-13.

${ }^{7}$ Charvat V. [Review] Михайло Грушевський: Впливи чеського національного руху XIV-XV вв. в українськім життю і творчості... Slovanský Přehled. 1927. Roč. XIX. S. 546.
} 
meaningful and valuable scientific journals and collections ("Ukraine", "In One Hundred Years", "Primary Citizenship"...)"s.

Further, J. Bidlo vividly depicted the unfavourable circumstances of the work of a Ukrainian scientist during the years of war and revolution, noting the complexity of writing and printing volumes of the Cossack cycle of "History of Ukraine-Rus", since materials collected for many years were destroyed together with the historian's house by the Bolshevik forces of Muravev in January 1918 in Kyiv. Thus, it was necessary to do all the preparatory work practically anew with the help of his Lviv and Kyiv students.

The ninth volume, as the reviewer emphasized, contained an enormous amount of new source material that the author readily shared with his reader. This saturation of the scholar's narrative with extensive quotations from sources, which was usually criticized by the Ukrainian observers of the ninth volume of "History of Ukraine-Rus", J. Bidlo presented as a positive trait since unknown texts became available to a wide range of researchers. Involving a large number of new documents allowed the Ukrainian scientist not only to reconstruct the unknown pages of Khmelnytsky era, but also to largely revise the stereotypical views established in science.

Quoting excerpts from the work of M. Hrushevsky, the observer drew attention to the conceptual aspects of the work in question, fully solidifying with the author. J. Bidlo provided numerous examples that showed the originality of the author's approach in solving many scientific problems, demonstrated his unbridled erudition and professional skills in the analysis of diverse sources and significant historiographical literature. The reviewer also noted the stylistic skill of the author, arguing that from that point on, the artistic value of "History of Ukraine-Rus" is steadily increasing so much that: "in the latter parts one can speak of a virtuoso writer".

Listing the debatable points of the ninth volume, J. Bidlo dwelled in detail on the characterization of the figure of Bogdan Khmelnytsky by M. Hrushevsky. He wrote about the considerable controversy of his assessments of this prominent personality, which, in the opinion of the Czech scholar, will contribute to the growth of interest both among researchers and among ordinary readers. According to J. Bidlo, M. Hrushevsky, "as a

\footnotetext{
${ }^{8}$ Bidlo J. [Review] Mychajlo Hruševs‘kyj, Istorija Ukraïny-Rusy. Tomu devjatoho perša polovyna. Časopis národního musea. 1931. Roč. CV. S. 130-131.
} 
supporter of modern collectivism", skilfully demonstrated who is actually a historical hero and how complex his relations with the masses can be. At the end of his review, the Czech observer noted an interesting source list in the book and extensive references ${ }^{9}$.

Summarizing his critical review, the Czech researcher pointed out: "The history of Ukraine-Rus" by Hrushevsky from its first part is a work, if not to say, of a brilliant, then of a highly talented scientist with synthetic abilities, who possesses not only the knowledge of source and scientific literature, but also of modern sociological-historical theory, and has a rare vision of the development of world history. It is also a patriotic work that has become a significant contribution to the creation and spread of national consciousness in the broad sections of the Ukrainian population and among educated people, but at the same time the story is generally impartial, presented from the angle of world history, measured by the standard of universal development"10. In view of this, as J. Bidlo assured, readers would look forward to the continuation of the important work of M. Hrushevsky about that crucial era of Ukrainian and Eastern European history.

Alongside with the review of J. Bidlo, the newspaper "Prager Presse", an informal speaker of the Ministry of Foreign Affairs, also responded with the review of the "The Flourishment and Decline of Ukraine". The ninth volume was called a new brick, which M. Hrushevsky put into the building of holistic synthesis of Ukrainian history carried out by him for decades. The reviewer emphasized at the significance of the events described in the new work not only from a historical point of view, since the last years of Khmelnytsky were marked by a powerful upsurge of Ukrainian struggle for independence, but also in view of their social resonance - the resemblance of the recent independence revolution of one of the largest Slavic peoples. Considering the solid historiographic tradition of the Cossack era in the writings of Ukrainian, Polish and Russian researchers, M. Hrushevsky managed to express his significant and original concept not only in the source-related aspect - involving a huge number of newly discovered documents, but also in an attempt to reconsider largely mythologized by the previous tradition historical facts and personalities. Compared to the works of the Cossack scholars of the nineteenth century, the ninth volume of the

\footnotetext{
${ }^{9}$ Ibidem. S. 142.

${ }^{10}$ Ibidem. S. 134.
} 
"History of Ukraine-Rus: “...does not present a radically new description of the hetman, but it shows a completely new presentation of personalities and events, it completely eliminated legends, and traditional romanticism is replaced by sober, scientifically grounded historical judgments" ${ }^{\prime 1}$. Despite the heroic nature of the described events, their importance in the future fate of the Ukrainian people, the researcher rested restrained and correctly reproduced the peculiarity of that turbulent era.

In the second half of the 1920's another multivolume studio of M. Hrushevsky "The History of Ukrainian Literature" was noticed by Czech observers. This work, although it was not marked by special reviews, was repeatedly mentioned on the pages of the Czech scientific journals when reviewing the novelties of Ukraine science. In these reviews, "The History of Ukrainian Literature" was unanimously attested to as a fundamental synthetic work - the organic addition to "History of Ukraine-Rus"12.

Alongside with the fundamental researches of M. Hrushevsky, Czech counterparts also reviewed his articles. Thus, the magazine "Českỳ Časopis Historickỳ" published the controversial article by M. Hrushevsky "The History of Slavic Literature - A Fiction or a Necessary Scientific Postulate?" - a response to the speech of the Polish Slavist Ventsislav Lednicki. Debating with a young Polish colleague, the Kyiv academician advocated the possibility and need for synthesis in Slavic studies. The reviewer of this discussion, $Z$. Hájek, completely agreed with the position of M. Hrushevsky ${ }^{13}$.

A peculiar result in the perception of M. Hrushevsky by his contemporaries was the widespread celebration the sixtieth anniversary of his birthday and fortieth anniversary of scientific and scientificorganizational activity in 1926. Among many letters addressed to the jubilee there were also congratulations from his Czech counterparts. M. Hrushevsky received the congratulations from the President of the Czech Academy of Sciences J. Zubaty ${ }^{14}$. Signed by J. Polivka and J. Yanko, there was also a sincere congratulation from the Czech Scientific Society: "The Royal Czech Society of Science, which includes the jubilee to its foreign members, cannot stay away from such an even.

${ }^{11}$ M. H. Der Ukraine Glanz und Niedergang (M.Hruševs'kyj: Geschichte der Ukraine). Prager Presse. 1931. № 99. S. 8.

${ }^{12}$ Zpràvy. Českỳ Časopis Historickỳ. 1927. Roč. XXXIII. S. 677.

${ }^{13}$ Z. Hájek Zpràvy. Českỳ Časopis Historickỳ. 1932. Roč. XXXVIII. S. 627.

14 Ювілей академіка М.С.Грушевського. 1866-1926. I. Ювілейні засідання. II. Привітання. Київ, 1927. Ст. 138. 
On the contrary, being full of sincere enthusiasm for everything that the researcher has reached in the domain of science in general, and Slavic and Ukrainian studies in particular, with joy and pride that we are among the first to congratulate him, we wish a lot of physical and mental forces to work and to complete his main project" ${ }^{15}$. Vaclav Novotny congratulated the famous historian and leader of the fraternal people on behalf of the Historical Society in Prague. In its turn, under the signature of Matviy Murko, the editorial office of the philological magazine "Slavia" congratulated the "Honored historian of Ukraine" prof. Mykhailo Hrushevsky, who enriched Slavic philology with his cultural-historical and literary-historical works"16.

Alongside with the congratulations from the institutions, personal greetings were also sent to the anniversary committee in Kyiv. The most touching among them were the greetings from J. Bidlo. Having received an invitation to take part in the commemoration of the Father of Modern Ukrainian Studies, the distinguished Czech scientist replied: "Thank you sincerely for your announcement of the 60th anniversary of the famous historian and patriot Professor Mykhailo Hrushevsky, I ask you to accept sincere manifestations of my dear respect for him and his work. I highly value all his scientific works, but I regard his "History of Ukraine-Rus" as a work of a world's scale, which belongs to the most prominent historical works. I consider the Ukrainian people's awareness as the influence of this work, because it was through its study that I gained a proper understanding of the Ukrainian question. [...] I wish the jubilee many happy years and fruitful work in scientific and public domain"17.

Responding to the celebration of M. Hrushevsky's anniversary, his Czech friends informed the country about it. The pages of the "Prager Presse" presented a letter written by J. Bidlo printed with a portrait of a jubilee. In this essay, for the first time in the Czech literature, the rich scientific, literary and political activities of the scientist were thoroughly characterized, with a special emphasis on the achievements of the most fruitful period of his life in Lviv.

In a more detailed presentation in his essay, the author dwelled on "History of Ukraine-Rus", which, in his words, "belongs to the largest and most notable works of historical literature of the whole world not only

\footnotetext{
${ }^{15}$ Там само.

16 Там само.

17 Там само. Ст. 139.
} 
because of its volume and richness of generalized material, but also due to its high professional level, its concept, breadth of vision and unusual scientific clarity" ". For J. Bidlo, the main work of the jubilee was a work that met almost all the requirements of the modern historiography, since it presented not a traditional depiction of political history, but a holistic version of the history of culture in which political history is only one dimension of integral entity.

Especially characteristic of the conceptional and methodological refinement were fifth and sixth volumes of his great work of M. Hrushevsky. The author depicted the synthesis of social, administrative, legal, ecclesiastical, economic and cultural relations that dominated in the Ukrainian lands from the fourteenth to the seventeenth century, that is, during the active creation of the Ukrainian nation. "Hrushevsky", as the Czech scholar emphasized, "wrote his work in the national Ukrainian spirit in order to serve as a Ukrainian and remain an objective historian in general. And precisely this impartiality resulted in the fact that anyone who wants to know in detail the history of the Ukrainian people can turn up to "History..." of Hrushevsky and understand that present desire of Ukrainians to be an independent nation is a natural consequence of the special historical development of the lands they inhabit" "In this sense, J. Bidlo compared the "History" of M. Hrushevsky with the work of the Czech philosopher F. Palacky about the past of the Czech people: both works written in a patriotic spirit and at the same time based on strict objectivity and met all scientific requirements. Therefore, it is logical for the Czech professor that "History..." of M. Hrushevsky had a tremendous influence on the progress and development of Ukrainian national life. J. Bidlo convinced that it would be a great idea to compare M. Hrushevsky with F. Palacky also in terms of their contribution to the organization of the scientific life of their peoples. After all, Ukrainian scientists owe SSS in Lviv and and UAS in Kyiv for their fruitful activity in the field of science.

Turning to the public activity of M. Hrushevsky for his people, J. Bidlo pointed at the immutability of his progressive aspirations, which allowed the author to notice the similarity of M. Hrushevsky with another prominent Czech, T. Masaryk. Briefly depicting M. Hrushevsky's political activity in the times of Ukrainian statehood (for its estimation, according to

\footnotetext{
${ }^{18}$ Bidlo J. Michajlo Hruševskij. Prager Presse. 1926. № 267. S. 5.

${ }^{19}$ Ibidem.
} 
J. Bidlo, there is still not enough time that passed for more objective estimation), the researcher paid tribute to M. Hrushevsky's decision to return to Soviet Ukraine, where the prominent historian took up organization of scientific work in very difficult financial circumstances. He stated that "Ukraine" seemed to be quite impressive in the scientific aspect, as well as a very valuable and original "History of Ukrainian Literature". By wishing the jubilee a good health and improved conditions for scientific work, J. Bidlo finally noted: "The value and merits of Hrushevsky have been appreciated in Czechoslovakia for a long time (1914), when he was appointed as a foreign member of the Royal Czech Scientific Society". In 1919, Hrushevsky became a member of the "Czech Academy of Sciences and Arts". I think that he would be happy if his popular "Illustrated History of Ukraine" was published in Czech. It would be very useful for mutual relations between Ukrainians and Czechoslovaks" ${ }^{20}$. The sincere sympathy, with which J. Bidlo's essay was written, aroused the grateful response of his Ukrainian colleague, who called the article "Prager Presse" as "one of the best I've ever seen",21.

The Czech Slavic magazine "Slovanský Přehled" also responded with an informative article on the anniversary of M. Hrushevsky. The author of the essay, philosopher-ukrainist Frantisek Tichý, accurately noticed that after the death of Lesia Ukrainka and Ivan Franko, it was M. Hrushevsky who became "an indisputable spiritual mentor of cultural Ukraine". Briefly depicting the life and creative path of the jubilee, he called him "one of the most outstanding and most prominent representatives of modern Slavs", the Czech researcher investigated in detail the Lviv period, because at that time the scientist launched a "worthwhile surprise of diverse activities"22. F. Tichý described the "History of Ukraine-Rus" as an epoch-making work, which, together with a productive scientific and organizational work, gave M. Hrushevsky a place of honor in the pantheon of European science. The productive activities of the jubilee also were noted in other areas: publishing, pedagogical, public, etc. Together, all this sacrificial work of a prominent figure for the benefit of Ukraine allowed without exaggeration, according to the Czech scientist, to call him "Father" of his people.

Considering the wide range of scientific interests of M. Hrushevsky in the domain of history, literature and sociology, F. Tichý separately

\footnotetext{
${ }^{20}$ Ibidem.

${ }^{21}$ Чеські адресати Михайла Грушевського. Хроніка-2000. 1999. Вип. 29-30. Ст. 25.

${ }^{22}$ Tichý F. Michajlo Hruševśkyj. Slovanský Přehled. 1926. Roč. XVIII. S. 643.
} 
emphasized at the contribution of the jubilee to the study of UkrainianCzech cultural relations and on the pages of his synthetic works, and in special studios. At the end of the essay, the author joined the assessments expressed by J. Bidlo, and on behalf of the Czech scientific world wished the historian strength and energy for new creative plans - "so that he managed to implement them all and wait for the fruits of his noble great vitality" ${ }^{\prime 23}$. We also recall that F. Tichý's article was supplemented by the portrait of a jubilee the same that illustrated the article by K. Kadlec in "Slovanský Prrehled" on the occasion of the 40th anniversary of M. Hrushevsky.

The communication between M. Hrushevsky and his Czech counterparts, well-established in the second half of the 1920's, is also evidenced by the participation of Ukrainian academician in the celebration of the jubilee of his Prague friend, J. Bidlo. In a scholarly book on the celebration of the sixtieth birth of a Czech scientist, the Kyiv historian published an article "The Unification of Eastern Slavs and Plans of Expansion in the Balkans in 1654-1655,"24.

The relationship between M. Hrushevsky and his Czech counterparts were violently interrupted by Stalin's repressions against Ukrainian science and one of its leaders, which unfolded at the turn of the 1920's and 1930's. From 1931, the scientist was in a "honorable" exile in Moscow, where, despite the considerable weakening of health (Hrushevsky was virtually blind), he continued to work on two major multivolume projects of his life, taking advantage of the unabated help of his daughter and wife. In the autumn of 1934, he and his family left for vacation to Kislovodsk, where he fell ill with carbuncles and died, during the unsuccessful surgical operation, on November 24.

\section{Honoring Memory}

The premature death of $\mathrm{M}$. Hrushevsky was with great concern perceived by the scientific community in the free world, in particular by his Czech counterparts and caused a real downfall of publications about the scientist. The first information about the tragic news from Kislovodsk to the Czech audience was sent by the Prague Radio on November 26, 1934,

\footnotetext{
${ }^{23}$ Ibidem. S. 645.

${ }^{24}$ Hruševs‘kyj M. Sjednoceni východního slovanstva a expansivní plány na Balkáně v letech 1654-1655. $Z$ dějin Východní Evropy a Slovanstva, in: Sborník věnovaný Jaroslavu Bidlovi, profesoru Karlovy University $k$ šedesátým narozeninám. V Praze, A.Bečková. 1928. S. 340-345.
} 
and the evening newspapers circulated this news. Already the next day, obituaries appeared in the authoritative Prague newspaper "Lidové noviny" 25 and other editions. In these writings, M. Hrushevsky was portrayed as a true patriarch of Ukrainian culture and science; he was compared with the great Czechs figure F. Palacki. Separately there was mentioned the tragedy of persecuted by the Soviet authorities researcher exiled from his native land.

Along with the daily press, academic journals also reacted to the death of M. Hrushevsky with memorial notes. In the obituary on the pages of the Prague "Českỳ Časopis Historickỳ" Z. Hájek called M. Hrushevskyi the most prominent Ukrainian scholar and public figure, whose influence was felt far beyond the borders of the Motherland: "His works had a tremendous pivotal significance, as well as the Ukrainian national movement was largely under his influence" ${ }^{, 26}$.

J. Slavik responded to the death of M. Hrushevsky with a brief obituary note on the pages of the "Slovanský Prrehled" magazine. By referring an interested reader to the previous reports about the Ukrainian scientist that appeared in the journal during the past decades, the Czech scientist summarized the achievements of the Soviet decade of the Kyiv academician's life. Speaking about the persecution of M. Hrushevsky by the communist authorities, J. Slavik accurately noted: "The fate of Hrushevsky during the World War, when he became victim of the tsarist government, repeated again in the worst form" 27 . With some irony, the author referred to the "posthumous honor and retirement" that the Soviet functionaries attributed to the scientist in order to improve their image in the eyes of the Western public after years of persecution of the scientist, calling it a "little compensation for the persecution that the great scientist has lately suffered".

Another vast obituary on the pages of the Prague "Slavische Rundschau" on the death of M. Hrushevsky was written by the long-time friend of the deceased J. Bidlo, who was well acquainted with his creative heritage, and with the general context of the progress of Ukrainian studies. In the beginning, the Czech scholar with dismay noted that instead of the anniversary article about the seventy years jubilee of M. Hrushevsky he was forced to write an obituary to his premature death, which became

\footnotetext{
${ }^{25}$ Dr. V. V. Michajlo Hrušovskyj zemřel. Lidové noviny. 1934. 27 listopada. S. 4.

${ }^{26}$ Z. Hájek Zpràvy. Českỳ Časopis Historickỳ. 1934. Roč. XL. S. 671.

${ }^{27}$ Slavik J. Michajlo Hruševśkyj. Slovanský Přehled. 1934. Roč. XXVI. S. 311.
} 
"an irreparable loss to the whole historical science". Schematically outlining the main facts of the biography of a Ukrainian colleague, the author focuses on the characterization of his creative heritage, calling it a fundamental one.

J. Bidlo called the "History of Ukraine-Rus" the culmination of all Hrushevsky's works, which, despite its incompleteness and some shortcomings, mentioned by the author himself, was still admired: "This work is, if not a brilliant, but a talented synthesis, which equally perfectly serves as a source material, and professional literature, is well oriented in contemporary sociological theories and has a rare panoramic vision of world history" 28 . The innovative character of the synthesis of M. Hrushevsky consisted in combining traditional political history with the history of culture, social institutions and economic processes. Despite its distinctly national character, "History of Ukraine-Rus" is at the same time an entirely objective work, which convinced the impartial reader of the suitability of author's hypotheses. This rare combination of patriotism and objectivity, as the author once again said, make the work of M. Hrushevsky resemble with the "History of the Czech People" by F. Palacky.

With the same enthusiasm J. Bidlo wrote about "The History of Ukrainian Literature". This work, according to his observation, is "...a kind of new edition of cultural literary passages from "History of Ukraine-Rus", is highly refined and supplemented". The author then briefly acquainted the reader with the richness of the issues of this fundamental studio, also noting its patriotic character that characterizes Hrushevsky as a researcher".

As a prominent organizer of Ukrainian science, M. Hrushevsky is best described by the multifaceted activities in Lviv, and later in Kyiv. In Galicia, the deceased succeeded in turning the SSS into the actual National Academy of Sciences. In the Soviet decade, his organizational talent was manifested in the development of research commissions and numerous publishing houses of the historical institutions of UAS. However, J. Bidlo accurately pointed out that "the new Soviet historiography" was a completely antagonistic towards the historical ideology of a Ukrainian scientist. Thus, the conflict was inevitable, and its consequences were quite predictable. Like his well-known predecessors,

\footnotetext{
${ }^{28}$ Bidlo J. Mychajlo Hruševs`kyj. Slavische Rundschau. 1935. Roč. 7. S. 62.
} 
M. Hrushevsky was forced to live for ages in actual exile. Summing up, J. Bidlo emphasized that "the loss of this unique personality for Ukrainian scientific life will remain irrecoverable for many years" 29 .

J. Bidlo was the first among non-Ukrainian authors who also wrote a general work devoted to the life and activity of M. Hrushevsky, which was published by a separate booklet in Prague in 1935. Having reacted with plenty reviews on the main works of a scholar, the Czech scientist was well acquainted with the circumstances of the activity of his Ukrainian colleague in different periods of his life, and the long-standing correspondence with $\mathrm{M}$. Hrushevsky made him aware of numerous unknown facts of his biography.

Already in the introduction, the author depicted the general traits of the deceased: "It was extremely fast and bright the scientific progress of this famous historian of the Ukrainian people; his scientific, literary and publishing activity was extremely fruitful, leaving a rich literary heritage; in the critical period of the Russian revolution of 1917, he had to play the exclusive role of the political leader of the whole people, and in the end to endure four difficult years of great suffering, since he was suspected of being politically dangerous. Because of this, he was torn away from his national environment, for which he was a source that nourished not only the scientific activity but also the life itself" ${ }^{\prime 30}$.

Then in the narrative biographical key, the author disclosed the main stages of the formation of M. Hrushevsky as an outstanding organizer of Ukrainian science, historian, literary critic, publicist, public and statesman, relying, at the same time, on the "Autobiography" of the deceased. Like other scholars, the Czech scientist gave a more detailed look at the achievements of Lviv period of life and activity of M. Hrushevsky, when he "received extremely favourable conditions for scientific work and thus published throughout several years a number of very important works".

The main efforts, as J. Bidlo correctly said, M. Hrushevsky directed at a great task to write a complete history of Ukraine. Briefly summarizing the content of each part of the "History of Ukraine-Rus", the Czech scientist noted that the author of the first volume "was surprised by the full knowledge of the material not only of historical (Arabic texts), but also of archaeological character, perfect knowledge of the literature and problems

\footnotetext{
${ }^{29}$ Ibidem. S. 64.

${ }^{30}$ Bidlo J. Michal Hruševs'kyj. Praha, 1935. S. 3-4.
} 
that were raised in it (namely, how the Rus state arose and who were Rus Vikings) and, in general, a new understanding of the Rus history". Recalling the reception of the main work of the deceased, J. Bidlo directly pointed to misunderstanding and the rejection of his original ideas by many contemporaries, first of all, his Russian colleagues ${ }^{31}$.

J. Bidlo commented favourably on the theoretical and methodological basis of M. Hrushevsky's historical studies, emphasized on his critical approach and objectivity, the respected erudition, and the skilful mastery of the sociological method. As the researcher pointed out that the Ukrainian colleague rightly selected as the object of his attention a wide range of manifestations of life of the Ukrainian people, synthesizing them in a coherent picture. He also pointed out at the magnitude of M. Hrushevsky's contribution to the development of the sources of Ukrainian historical science. All this, as the Czech scientist insisted, made the role of M. Hrushevsky in Ukrainian science commensurate with the value of F. Palacky for the Czechs ${ }^{32}$.

Explaining the significance of the public service of Hrushevsky, J. Bidlo insightfully noted: "Not only those who had doubts whether to be considered Rusyn or Ukrainian or whether Ukrainians in general were just a fiction, but also those who from afar observed the Ukrainian people's movement learned from the work of Hrushevsky that Ukrainian aspirations have deep roots in the historical development of society, which made it a natural phenomenon in general".

Separately J. Bidlo noted the importance of the scientific popularization activity of M. Hrushevsky. According to his observation, such popular works as "The Essay on the History of the Ukrainian People" and "Illustrated History of Ukraine" had a much greater influence on the Ukrainian and, in general, the Eastern European readership. "It can be said", J. Bidlo pointed out, "that Hrushevsky, through all his multifaceted activities made the most effective service to his Motherland".

$\mathrm{He}$ also mentioned the talent of M. Hrushevsky as the organizer of Ukrainian scientific life. As in his previous reviews, he called the reformed SSS the actual Academy of Sciences. He wrote about the creation of new scientific sections and periodicals, mentioned the education of many talented students who continued the project of the teacher.

\footnotetext{
${ }^{31}$ Ibidem. S. 7-9.

32 Ibidem. S. 13.
} 
He paid attention to M. Hrushevsky's public-political and journalistic activity, pointing out its importance for the modernization of Ukrainians. In elucidating the public credo of the Lviv professor, the author rightly stated that he has always been a supporter of the progressive direction, the successor of the establishment of an equitable interethnic dialogue in Galicia. After 1905 these ideas of M. Hrushevsky moved to Dnieper Ukraine, which he regarded as the core of national life.

J. Bidlo naturally defined the main role of M. Hrushevsky at the first stage of the Ukrainian revolution as a prominent one, when he was unanimously elected a chairman of the Central Rada. In general, sympathetically depicting the activity of his colleague, the Czech scientist did not skip his mistakes as a politician, referring to the witness of that time, his Prague colleague Dmytro Doroshenko.

Briefly describing the exile of $M$. Hrushevsky, the researcher summed up the naturalness of his decision to return to the Bolshevik Ukraine. The latter was due not only to the scientific plans of the scientist, but also to his ideological beliefs in the necessity of not being indifferent to his people ${ }^{33}$. The justification for such a step, was the "amazing" scientific, publishing and organizational achievements of the Soviet era of M. Hrushevsky's life, according to J. Bidlo. For the first time in Czech historiography the researcher summarized and accurately characterized "The History of Ukrainian Literature." According to J. Bidlo, this studio "... was written by a historian who has previously proved to be the author of a great historical work in the direct sense of that word, and then took up the history of literature with a deeper interest, in particular social and sociological aspects".

The Czech scientist depicted the last years of Ukrainian scientist's life as full of deep tragedy. Despite the deterioration in his health, Hrushevsky managed to continue his work. Describing the essence of the conflict of the deceased with the Bolsheviks, J. Bidlo accurately noted: "[...] Judging from his writings, [M. Hrushevsky] was essentially a scholar, a historian, who was primarily concerned with the knowledge and disclosure of pure truth. That was the tragedy of his attitude towards the Bolshevik authorities, who had nothing to do with anything similar at all, who could not understand the soul and the efforts of a true scientist, and instead understood science as utilitarian and additional to politics".

${ }^{33}$ Ibidem. S. 26-27. 
At the end of the book, J. Bidlo shared with the reader his personal impressions from the long-standing acquaintance with M. Hrushevsky, noting the determining character of his personality. The testimony of a Czech scientist about his last meeting with a Ukrainian colleague on the eve of his return to Ukraine is interesting as well. In a confidential conversation, M. Hrushevsky said that he decided to accept the Ukrainian Bolshevik authorities, considering that the further struggle of Ukrainians with it was pointless ${ }^{34}$. The scale of the creative heritage of the author of "History of Ukraine-Rus" for the Czech reader was illustrated by a chronologically completed list of the main scientific works that the Ukrainian historian added to the book.

By its detailed description, the work of J. Bidlo about Hrushevsky drew the attention of observers of scientific life. In his review, Z. Hajek summarized the main ideas of the work, fully agreeing with the thesis that M. Hrushevsky's contribution to the development of Ukrainian and Slavonic culture and science was an outstanding on.

The final chord of the Czech Hrushevsky studies became brief notes on the publication by M. Hrushevsky's daughter, Catherine, of the last tenth volume of "History of Ukraine-Rus" in 1936. For example, on the pages of the Prague "Časopis národního musea" J. Bidlo briefly acquainted the reader on the content of the latter part of the main work of Ukrainian colleague. The Czech historian, with clear sadness, congratulated the "valuable" work on the Ukrainian past, which, regarding the method, structure and new source material, resembled previous volumes ${ }^{35}$.

\section{CONCLUSIONS}

Summing up the Czech Hrushevsky studies, we draw attention to a certain symbolism of the favourite comparison of Czech intellectuals of M. Hrushevsky with F. Palacky. Similarly to the famous Czech scientist, it was the Ukrainian historian who, through his numerous works, in which he skilfully united the love for his people and positivist objectivity, introduced to the world around Ukraine and Ukrainians.

Czech assessments of the various works of M. Hrushevsky were generally objective and, in general, quite favourable. The absence of mutual historical conflicts, the similarity of the experience of foreign

\footnotetext{
${ }^{34}$ Ibidem. S. 34.

${ }^{35}$ Bidlo J. Zprávy. Časopis národního musea. Oddíl duchovědný. 1937. Roč. CXI. S. 156-157.
} 
oppression, the traditionally strong Czech-Ukrainian cultural relations, personal friendly relations between the scientist and the foremost representatives of the scientific world of Bohemia created a favourable atmosphere for building a fully-fledged international historiographical dialogue, not burdened with imperial heritage or mutual claims, as in case with Russia or Poland. In this uneasy dialogue on the Ukrainian side, M. Hrushevsky played a leading role.

Despite some reservations about his daring historical modelling, which the majority of his contemporaries did not understand, the Czech scholars with great acknowledgment relate to the versatile and sacrificial cultural activity of his Ukrainian counterpart, carefully monitoring the appearance of his scientific works. Hence, the greatest recognition of Czech scholars was attributed to scientific and organizational work of M. Hrushevsky, which, in their conviction, legitimized Ukrainian studies as an important direction of Slavic studies. In this context, the general recognition of the epochal nature of the work of Hrushevsky is traditional for Czech writers, as he was compared with the F. Palacky, who was in the same way important for the Czechs. Therefore, it is no coincidence that the greatest academic award, the status of a foreign member of the National Academy of Sciences, was attributed Ukrainian researcher in the Czech Republic. Czech historiography has in its turn the most delusional, beyond the Ukrainian literature, Hrushevsky studies: special publications devoted to M. Hrushevsky, mainly on the occasion of his anniversary dates, reproduced the image of the prominent Slavic scholar, the tireless worker on the field of Ukrainian culture, the principal protector of national interests.

\section{SUMMARY}

The article is devoted to the study of the reception of the scientific heritage of M. Hrushevsky in Czech science and journalism in the interwar period. The results of his expanded activity as a head of the historic institutions of UAS, renewed an active discussion of the Czech researchers. The Czech colleagues were especially impressed with the establishment by scholars of wide publishing activity, which quickly led to considerable changes. It has been proved that in comparison with the certain degree of bias in the writings of Polish and Russian observers of M. Hrushevsky's activity, Czech scientists were generally objective and giving approving 
reviews. Such a reaction was facilitated by the absence of mutual historical claims, the similarity of the experience of imperial oppression, the traditionally strong Czech-Ukrainian cultural relations, and the personal and friendly relations of $M$. Hrushevsky with many prominent contemporary Czech scholars (L. Niederle, J. Bidlo, T. Masaryk, $\mathrm{K}$. Jireček etc.). A conclusion has been made about the richness of the Czech Slavic studies with elements of Hrushevsky studies.

\section{REFERENCES}

1. Bidlo J. [Review] Mychajlo Hruševs'kyj, Istorija Ukraïny-Rusy. Tomu devjatoho perša polovyna. Časopis národního musea. 1931. Roč. CV. S. 130-131.

2. Bidlo J. [Review] Ukraina, naukovyj tr'òchmisjačnyk ukrainoznavstva za rok 1924. Časopis národního musea. 1925. Roč. XCIX. S. 83-87.

3. Bidlo J. Michajlo Hruševskij. Prager Presse. 1926. № 267. S. 5.

4. Bidlo J. Michal Hruševs 'kyj. Praha, 1935. 43 s.

5. Bidlo J. Mychajlo Hruševs'kyj. Slavische Rundschau. 1935. Roč. 7. S. 62.

6. Bidlo J. Zprávy. Časopis národního musea. Oddíl duchovědný. 1937. Roč. CXI. S. 156-157.

7. Charvat V. [Review] Михайло Грушевський: Впливи чеського національного руху XIV-XV вв. в українськім життю і творчості... Slovanský Přehled. 1927. Roč. XIX. S. 546.

8. Charvat V. [Review] Україна. Науковий двохмісячник. Slovanský Přehled. 1927. Roč. XIX. S. 72-73.

9. Charvat V. Časopisy. Slovanský Přehled. 1926. XVIII. S. 481-482.

10. Dr. V. V. Michajlo Hrušovskyj zemřel. Lidové noviny. 1934. 27 listopada. S. 4.

11. Hájek Z. Zpràvy. Českỳ Časopis Historickỳ. 1929. Roč. XXXV. S. 224.

12. Hájek Z. Zpràvy. Českỳ Časopis Historickỳ. 1932. Roč. XXXVIII. S. 627.

13. Hájek Z. Zpràvy. Českỳ Časopis Historickỳ. 1934. Roč. XL. S. 671. 
14. Hruševs'kyj M. Sjednoceni východního slovanstva a expansivní plány na Balkáně v letech 1654-1655. Z dějin Východní Evropy a Slovanstva, in: Sborník věnovaný Jaroslavu Bidlovi, profesoru Karlovy University $k$ šedesátým narozeninám. V Praze, A.Bečková. 1928. S. 340-345.

15. M. H. Der Ukraine Glanz und Niedergang (M. Hruševs'kyj: Geschichte der Ukraine). Prager Presse. 1931. № 99. S. 8.

16. Slavik J. Michajlo Hruševśkyj. Slovanský Přehled. 1934. Roč. XXVI. S. 311.

17. Tichý F. Michajlo Hruševśkyj. Slovanský Přehled. 1926. Roč. XVIII. S. 643.

18. Zpràvy. Českỳ Časopis Historickỳ. 1927. Roč. XXXIII. S. 677.

19. Грушевський М. Впливи чеського національного руху XIV-XV вв. в українськім життю і творчості, як проблема досліду. Кілька заміток і дезидерат. Записки НTШ. 1925. T. CLI-CLIII. Ст. 1-13.

20. Тельвак В. Чеська грушевськіана першої третини XX століття. Історіографічні дослідження в Украӥні. 2008. Випуск 19. Ст. 240-258.

21. Чеські адресати Михайла Грушевського. Хроніка-2000. 1999. Вип. 29-30. Ст. 20-25.

22. Ювілей академіка М.С.Грушевського. 1866-1926. І. Ювілейні засідання. ІІ. Привітання. Київ, 1927. 143 ст.

\section{Information about the author: Telvak V. P.,}

$\mathrm{Ph} \mathrm{D}$ hab. (History), Assistant Professor, Department of World History and Special Historical Disciplines, Ivan Franko Drohobych State Pedagogical University 48, M. Hrushevsky St., Drohobych, 82100, Ukraine 


\section{HISTORY OF AGRICULTURE IN UKRAINE DURING THE INTEGRATION OF STATE REGULATION SYSTEMS}

\section{Vergunov V. A.}

\section{INTRODUCTION}

Historically agriculture was and still remains the leading industry for all civilizations and governmental systems on the territory occupied by modern Ukraine, also known as «On Stimulation of Agricultural Development for the Period 2001-2007» of January 18, 2001, № 2238-III, «... the type of economic activity in production, which is associated with biological processes of its cultivation, intended for consumption in raw and processed form and for use in non-food purposes ...» ${ }^{1}$ according to Article 1 of the Law of Ukraine. Understanding the fundamental place of agriculture for the Earth, the French philosopher Jean-Jacques Russo highlighted: «Agriculture is the only way to keep the country independent. Should you possess all possible wealth, but you have nothing to eat - you depend on others. Trade creates wealth, but agriculture provides freedom» ${ }^{2}$.

Taking into consideration mentioned above, referring back to agricultural sector experience is a deal breaker in overcoming existing challenges and development of the branch. A number of publications devoted to the history of agricultural development in Ukraine have fundamental importance, e.g. Lanovik B. ${ }^{3}$, Zavalnyuk O., Rybak I. ${ }^{4}$, and others ${ }^{5}$. However, experience gained in the search and implementation of the latest approaches to increase the efficiency of the industry, continues to interest domestic researchers.

\footnotetext{
1 Закон України «Про стимулювання розвитку сільського господарства на період 2001-2004 pp.». Відомості Верховної ради України. 2001. № 11 (1 берез.). С. 233-237.

2 Жан-Жак Руссо. Про суспільну угоду, або принципи політичного права. Переклад з французької та коментарі : О. Хома. Київ : Port-Royal, 2001. 349 с. 1995. $480 \mathrm{c}$.

3 Історія господарства : Україна і світ: підручник/ за ред. Б.Д. Лановика. Київ : Вища шк.,

4 Завальнюк О.М., Рибак І.В. Новітня аграрна історія України. Кам’янець-Подільський : АбеткаНова, 2004. 287 с.

${ }^{5}$ Історія українського селянства. Нариси в 2-х томах. Т. 2. Київ : Наук. думка, 2006. 654 с.
} 
In this regard, the purpose of this work is to highlight the general features of state regulation of agricultural development in Ukrainian territories at the end of the XIX - early XXI centuries on the basis of the application of the principles of historical search (historicism, objectivity, systemacity, continuity, complexity, etc.) and systems of complementary methods (general scientific, interdisciplinary and actually historical).

\section{Development of Agriculture in the Imperial Era}

From history it is known that wars, revolutions, resettlement, reforms accelerate the development of the agrarian sector. So, after the Crusades, a widespread introduction of the autumn fallow occurred; after the Reformation - the potato was introduced into the cultivation and the fertilization spread; together with the Great British Revolution, received a seed drill, a horse hack, and improved methods of cultivating the soil; after the Great French Revolution, introduced a culture of sugar beet; Political changes in Western Europe during the years 1848 to 1849 stimulated the massive spread of fecundity and mineral fertilizers.

For the Russian Empire, which comprised $85 \%$ of the present Ukrainian lands, such radical changes occurred, if not to take into account 1812 - the time of the First World War, which forced the landlords to evict to their rural estates and to engage agricultural management ${ }^{6}$ in proper way, after the abolition of serfdom in accordance with the manifesto of Alexander II in February 19, 1861, «On the All-Gracious Gift to bonded peasants the Status of Free Rural inhabitants». The main thing that gave the royal manifesto is personal freedom and civil rights: now the peasant had the rights on movable and immovable assets, to enter into agreements, to act as a legal body, to marry without the landlord's consent, to go to service and to educational institutions, to change the place of residence and even go to the cohort of townspeople and merchants. Within two decades after the reform, the country's population increased by $28 \%$ and reached 64 million people, which led to a reduction in the load of one desiatina of arable land from 4.8 to 3.8 des. Droughts that caused enormous damage (in the 18th century there were 34 , and in the 19 th century $-40^{7}$ ), they urged to look for alternative ways of solving food safety issues at the state level by obtaining

\footnotetext{
6 Вергунов В.А. Перші Всеросійські та місцеві з'їзди діячів сільськогосподарської справи : організація, напрямки роботи, значення. Історія укр. науки на межі тисячоліть. 2002. Вип. 7. С. 14-15.

${ }^{7}$ Власюк П.А. Содружество русских и украинских ученых в развитии сельскохозяйственных наук. Науч. тр. Отделения с.-х. наук Ан УССР. Київ, 1956. С. 3-15.
} 
sustainable yields of the main field crops, especially grains. According to the results of the World Exhibition in 1893 in Chicago, dedicated to the 400th anniversary of the discovery of America by $\mathrm{H}$. Columbus, the indicators of its quality were better than the then major exporters, and especially England and France, which, taking into account climatic conditions, were obliged to engage in production, first of all - grain.

Thanks to such an understanding of the place of agriculture in the life of the country, according to the decree of Alexander II in June 1893, March 21, 1894 profile department was established for the first time in the history of the Motherland - Ministry of Agriculture and State property, headed by a famous scientist, agrarian and statesman Yermolov O. Among his state-building decisions - the maximum budget support for the development of domestic agricultural research as an organization through the creation of a network of diversified research institutes in the country's natural and climatic zones, which, according to the decree of Nicholas II of May 28, 1901, approved the «Regulation on Agricultural Research Institutions» for the first time, it has received state recognition as an effective measure to improve the productivity of fields and farms ${ }^{8}$. In this case, only one digit must be given. In 1883 the average yield of winter wheat in the Poltava province was $7.21 \mathrm{c} / \mathrm{ha}$, and in 1913 it reached the level of $13.0 \mathrm{c} / \mathrm{ha}$.

In addition, some progressive landowners had $15.2 \mathrm{c} / \mathrm{ha}^{9}$. According to expert opinion, such successes for a country, that at the beginning of the XIX century for three hundred years lag behind the leading countries of Europe in development of agriculture, in 1913 made it possible to be in top of five exporters not only produced, but also processed agricultural products.

In this light, I think it is necessary to highlight the positive and negative effects of the introduction of Stolypin's agrarian reform on $85 \%$ of the current Ukrainian lands. I cannot but agree with the ingenious scientist, the founder of the scientific soil science Dokuchaev V., who noted: «... People of science have been warned against impending threats for decades... provided dozens of projects and petitions for research ..., projects were sometimes tested ... and were supported ... but, if not always,

\footnotetext{
${ }^{8}$ Положение о сельскохозяйственных опытных учреждениях. Известия Министерства земледелия и государственных имуществ. 1901. № 29 (22 июля). С. 546-547.

9 Коваленко Н.П. Становлення та розвиток науково-організаційних основ застосування вітчизняних сівозмін у системах землеробства (друга половина XIX - початок XXI ст.). Київ, 2014. С. 86.
} 
in the vast majority of cases received approximately the following answers: - no funds; - there are more important problems; - this issue is outlined; the country is large, it is not explored at all; - your work will extend on decades of years, God knows how matters will turn out...» ${ }^{10}$.

Coordinating, the Ministry of Agriculture and State Property was preparing the reform. But the main generating burden was taken by Prime Minister Stolypin P., because, as you know, history is made by the personality. Consequently, according to the agrarian-economic concept of Stolypin P., the chronological reform took place from November 9, 1906, to the October events of 1917, in particular till the adoption of the Decree on the land of V. Lenin on November 8, 1917. Despite the fact that the official date of decision on Stolypin's agrarian reform was November 9, 1906, some transformations began earlier in the countryside. Thus, on August 12 and 27, 1906, two decrees were passed on the transfer of 1 million 800 thousand acres of dividends and state lands to the peasant bank for sale to the peasants.

According to the Decree «On supplementing some of the resolutions of the current law affecting peasant land tenure and land use» of November 9, 1906, signed by Nicholas II on the proposal of Stolypin P., it was supposed to take such measures: the allocation of peasants from the communities and the consolidation of land for them in private property; creation of a homestead and individual farm; resettlement policy. Their implementation was closely linked to the work of the Peasant Bank, the cooperative movement, relations in the countryside, agriculture, etc. Contrary to the plans for land nationalization, Stolypin P. advanced the liberal doctrine of the gradual liquidation of the rural community, the development of private property in the countryside and the achievement of economic growth on this basis. He stressed repeatedly that the peasant should choose the way of using the land that he liked.

The decree of November 9, 1906 made adjustments to the legislation of the previous most significant reform, dated 1861, concerning the community and communal property. If before 1906 the community was considered to be the owner of an allotment land and the right to use it belonged to all its members, then since 1906, the peasants could isolate the land from the community, regardless of its thought. Already adopted Law in November 9, 1906 on the withdrawal of peasants from the communities

${ }^{10}$ Докучаев В. В. Избранные сочинения. Москва : Сельхозгиз, 1954. С. 427-428. 
in June 14, 1910 introduced a new addition which stated all communities having no land allocation amendments were considered privately owned by landlords. The opinion of one member of such a community became law and extended to all farms.

The essence of agrarian reform was to create a land fund and transfer the land from it to the peasants. The implementation of this plan should have been as follows: initially, the land plot provided to the peasant temporarily, and subsequently - secure the area of the state lands to the peasant, providing water and other agro-cultural use conditions. Thus, along with the community, a wealthy peasant, a true landlord, would be there. Such an evolutionary way of solving the peasant's problem was reduced to the growth of peasant farms in the highest type - farmer-oriented, market-oriented. Agrarian system in the country Stolypin P. saw as a system of small and medium-sized farms and small noble estates, united by local self-government.

The question of development of agriculture in Stolypin's way is controversial. Some experts believe that the version of American farming was leading in the reform of the village, since it consisted in the withdrawal of peasants from communities and the creation of farms. Others followed the opposite - Prussian, which kept landlord's land tenure. Therefore, we can assume that due to Stolypin P. it was worked out a peculiar national path, in which there were elements of the two aforementioned directions of agricultural development. Its essence was based on four systems: state, community, large private and family labor, or small private. Thus, the economy of agriculture has become more and more complex, which also provided progress in the agrarian sector.

Stolypin's P. proposed reform of the agrarian sector, which simultaneously envisaged important changes in political relations on the ground, provoked opposition, first of all, of the fellow courtiers of the country and certain revolutionary parties. As the Stolypin's P. daughter Maria Bok-Stolypina subsequently wrote: "When every peasant became a small landowner and farm work was in progress, the party of the SocialRevolutionaries was destroyed. Therefore, their desire to stop the reform is understandable. The work of this party was manifested not only in agitation among the peasantry ... but, in general, in artificial propaganda against my father and the organization of constant attempts on his life» ${ }^{11}$ (11 attempts were made).

${ }^{11}$ Бок М. П. Воспоминания о моем отце П.А. Столыпине. Москва : Тов. А. Н. Сытин и Кㅇ, 1992. 
From 1906 to May 1, 1915, 468,000 households came out from peasant communities of seven Ukrainian provinces, receiving $2,794,000$ acres of land in private ownership, or $30.2 \%$ of the total area of communal land. Characteristically, $57 \%$ of the peasants who left the community and consolidated the land into private ownership were Ukrainian farmers. Although, the land value was higher for them, than in other regions of the Empire. In the steppe zone, the price of one dessiatina was 172 rubles 30 kopecks, and in the neighboring Kursk province 122 rubles 60 kopecks. Those, who could not immediately pay, arranged a credit with a Peasant Bank for 20 years with an annual payment of 4 rubles or $1.5 \%$ per annum, which was significantly cheaper than a lease payment. At that time the peasant earned 75 kopecks per day in the summer at the landlord farm ${ }^{12}$.

For three decades of its existence, from the 80's of the XIX century at the time of Stolypin's reform the social structure of the buyers of the Peasant Bank changed significantly. Initially these were communities and societies, and then private peasants. The ones gained 2.35 million for the period 1909-1919, and the others - 2.9 million acres of land. At the same time, the sizes of self-employed farmer's land increased and the average area of which in 1908-1913 increased from 10 to 18 acres. For this purpose, the land surveying commission of the Russian Empire, during the period 1906 to 1910, allocated 9230725 rubles (at that time the cost of cow was 5-6 rubles.). In total, peasants received about 10 million acres of land with the help of the bank in the years of reform. Of this amount 480 thousand acres of land were sold by landowners of Ukraine, and in general for 1906-1910 aristocratic possession decreased by 1.1 million acres ${ }^{13}$. Stolypin P. encouraged those peasants who took the land into private property, lowering the fee for that. By a decree of January 1, 1907 , land redemption payments were canceled in general.

In the period of the Stolypin's reform peasants continued to gravitate to the lease of land. By 1917 43.2\% of the peasant landlords of Ukraine were in lease relations, which covered 6287 thousand acres of land. Although, for example, in the Volyn province only $3.1 \%$ of the peasant households farm out in part or in whole. The cost of a leasehold landed

\footnotetext{
12 Вергунов В.А., Коцур А.П., Коцур В.П. Україна та столипінська аграрна реформа: передумови, завдання, здійснення : монографія. Київ : ННЦ «Ін-т аграрної економіки», 2008. С. 89.

13 Панченко П. П., Кириленко І. Г., Вергунов В. А. Аграрна історія України : еволюція соціальноекономічних відносин : навч. посіб. Вид. доп. і перероб. Київ : Аграр. наука, 2014. 536 с.
} 
property in the Poltava province amounted to 16 rubles in the year, and multi-term -9 rubles. 70 kopecks. The last one was the most widespread. The metayage was not profitable. The main task of homestead and individual farm was the elimination of multiple and strip farming.

The most active transition to settlements was the in the farms of the Volyn province and especially in Zhytomyr region. In some counties it reached up to $80 \%$. At the beginning of $1916,440,000$ homesteads and individual farms operated in Ukrainian villages, or $13 \%$ of the total number of peasant households, despite the high cost (from 100 to 300 rubles.) for transferring from the village to the homestead.

Stolypin's reform provided an increase of yields from 1906 to 1915 by $14 \%$ and in some provinces by $20-25 \%$. The harvest of the main grain crops has grown from 2 billion pounds in 1884 to 4 billion pounds in 1911, or $28 \%$ up, which exceeded the aggregate figures of the USA, Argentina and Canada. In 1912, tallow oil was exported to England worth 68 million rubles, which was twice the cost of annual production of Siberian gold. Compared to 1884 , the horse population increased by $37 \%$, and cattle - by $63 \%$. As of 1913 , meat consumption in the country amounted to $88 \mathrm{~kg}$ per year per head of the population. Due to the allocation of farms and plots of land from communities to peasants, the sown area in Ukraine in 1910-1919 increased by 900 thousand acres, and in 1913 amounted to 2.9 million acres, $90.5 \%$ of which occupied by grain crops. As a result, $90 \%$ of total exports of winter wheat of the Russian Empire were exported from Nikolaev to England, France, Norway, Belgium, Germany, Holland, Italy, Austria, Spain, Tunisia, along with meat, oil, animal oil, lard, sugar, live livestock, poultry, sheep, etc. As of 1913, 586 distilleries were operating in Ukraine, producing 13.5 million buckets of alcohol. A convincing factor of the development of Ukrainian agriculture after the Stolypin's reform was the accumulation of peasant funds in savings banks. If in 1905 the sum of such investments amounted to 11115 thousand rubles, then in 1914 14278 thousand rubles ${ }^{14}$.

Initially, agricultural cooperatives were set up on the initiative of government instructors through loans from the State Bank. Subsequently, their support was Zemstvo small cash loans and the system of peasant credit co-operation. In 1906-1919, their number reached 4,715 societies.

\footnotetext{
${ }^{14}$ Вергунов В.А., Коцур А.П., Коцур В.П. Україна та столипінська аграрна реформа:передумови, завдання, здійснення : монографія. Київ : ННЦ «Н-т аграрної економіки», 2008. 132 с.
} 
At the same time with consumer co-operation, credit co-operation has also developed. This led to the emergence of meat and dairy and butter-making artels, consumer shops, peasant artel dairies. By October 1917, about 20 thousand different production cooperatives functioned in the Ukrainian village. All of this cooperation experience is currently used in Sweden, Finland, Austria, Belgium, Canada, Holland, etc. Stolypin's reform prompted the intensification of the training of specialists and the spread of agricultural knowledge among the rural population through them and thus increased the efficiency of agricultural production on the basis of the «Regulation on Agricultural Education» of May 26, 1904. With that in 1910 Stolypin P. instructed to stop teaching in Ukrainian language, to close Ukrainian cultural societies and publishing houses. Under sectoral educational institutions, specialized research fields and even stations were created. All together, the infrastructure of the Ukrainian village was altered by building highways, creating supply organizations to provide farmers with the necessary agricultural machinery, tools, etc.

On a voluntary basis, in accordance with the Decree of March 10, 1906, the peasants moved to Siberia, Central Asia and the Caucasus to increase land holdings. Between 1906 and 1910 more than 2.5 million people were displaced. They were provided free medical care. Transportation for the migrant cost only a quarter of the fare, and children less than 10 years of age transported free of charge. Most of Ukrainians (1 million), especially from Poltava region and Chernihiv region (350 thousand people), went out to Siberia. As of 1911, they received 24483 plots of land, which made it possible to increase the sown area up to $80 \%$. Although some of them turned back, more likely, because of the fault of responsible authorities for the allocation of land. Especially this tendency was traced in 1910-1919. Crop failure of the last year also factored on the situation. In 1914, Russia was visited by an official German delegation led by Professor Augagen to study the positive results of the Stolypin's reform. In its report it was noted that after the completion of this land reform, the war with Russia would not be beyond any state's power.

\section{Features of the Development of Agriculture from 1917 to Present Time}

After the seizure of power by the Bolsheviks, on November 8, 1917, a Decree went through where the landlord's ownership was canceled without any ransom, and all belongings and estates of the monasteries, churches, 
private and public were handed over to land committees and county councils of peasant deputies. The next document was the «Basic Law on the Socialization of Land», approved by the Central Executive Committee on February 9, 1918, which focused on specific issues of collectivization. On March 19, 1918, this law entitled «Temporary Provision on the Socialization of Land» was adopted in Ukraine. To some extent, the abolition of private property right of land is also referred to in the Third Universal on November 7, 1917, in favor of the labor class, however provisions on movable and immovable property are missing, which caused the indignation of most peasants in favor of the Decree on Land, Lenin V. and led to the so-called peasant war, the victims of which in 1918-1920 were about 7 million people.

According to the Circular Letter of the NCA of the Ukrainian SSR on the organization of communes of March 8, 1919, and the «Regulation of the Central Executive Committee on Socialist Agriculture» of May 26, 1919, a course was adopted on the forced planting of collective farms and state farms in the Ukrainian village. The dynamics of their growth is impressive. Those increased from 20 in 1918 to 1685 by spring of 1919 . Along with the complex of authorities' punitive actions it was possible to increase grain procurement to 71.5 million pounds of grain in 1920, compared with 10.5 million pounds in 1919. At the same time, the authorities ignored the cooperation in the countryside, despite the Decree «On Consumer Communes» (March 16, 1919). At the beginning of 1917 there were 31 thousand rural consumer societies operating in the country, whose members were 7.5 million people, and 25, 6 thousand agricultural and locally-industrial cooperatives, counting 11 million people and more.

After the proclamation of Lenin's V. new economic policy (NEP) at the end of 1922 - at the beginning of 1923, the state's attitude towards cooperation as an effective means of agricultural management changed, which, through the adoption of the Decree on the allocation of agricultural cooperatives into a separate structure, took the course for the revival of cooperation for 20,9 million people who lived in the countryside. It was extremely important in the conditions of the famine of 1921-1923 in Ukraine after the drought of 1921, which covered 21 districts of the Ukrainian SSR and took lives, according to various data, 5 million people. As a result, only 637 million pounds of grain were collected which is only $40 \%$ of the 1916 crop. Protest actions among the peasantry prompted the 
authorities to adopt the decree «On measures to restore the peasant economy» of December 30, 1921, which abolished the course for forced integration of the «socialist land use» ${ }^{15}$.

The Decree of the SNC of the Ukrainian SSR on the segregation of agricultural cooperatives from the unified system of consumer cooperation allowed the state to form a joint stock company «Selo-Dopomoga» in the spring of 1924. During 1924-1925 it also included the All-Ukrainian Union of Dairy and Dairy Cooperatives «Dobrobut», «Ukrsiltsukor», «Plodospilka» and others. However, this did not allow achieving price parity of purchasing capacity between cultivated products and the opportunity to buy products of factory production. The plow in 1913 costs 6 pounds of wheat and in 1923 expenses increased four times. This gap caused the village a loss of 500 million rubles, which is a half of the effective demand. But a convincing indicator of the revival of productive villages in the agrarian sector in the conditions of the NEP was the production of grain. If in 1921, 227 million pounds of grain were collected, in 1922 - about 637 million, then in 1926 - 1,057 million pounds. However, this figure has not reached the level of 1911-1915 with its 1084 million pounds. Bread-harvesting crisis of 1927-2928, which obliged «voluntarily» to hand over an additional 20 pounds of wheat to each farm, virtually curtailed the NEP through its own method of procurement, called «Uralsky-Siberian» by J. Stalin's. As a result, in the spring of 1929, almost 18,000 farms declared «kulak» sold out in Ukraine, and 33,000 peasants were brought to court for «speculation» by bread.

In the spring of 1929 the first five-year plan for the development of the economy was approved by J. Stalin, and announced as «the year of the great turning point». Such an approach to the activities of all components of the economy through the state order remained effective until Ukraine gained statehood. At the time of the official approval of the planeness of the work - on October 1, 1928 - there are 280 communes, 2,718 artels and 8,084 joint cultivation companies or 11,082 units. For the deployment of solid collectivization, which was planned for Ukraine at the level of $30 \%$, with $18-20 \%$ for the USSR, 27 thousand «twenty-five thousandths» were sent, which in January 1930 underwent special two-week preparatory courses. In addition, in the spring of 1930, 72204 workers, 13 thousand

\footnotetext{
${ }^{15}$ Панченко П. П., Мельник Ю. Ф., Вергунов В. А. Аграрна історія України. Навч. посіб. Київ : ВЦ «Просвіта», 2007. 532 с.
} 
Komsomol accountants, 50 thousand ordinary soldiers and junior commanders, as well as 23500 special commissioners were sent to the village from the city. As of June 1, 1930, all together, it was possible to dispose of 90 thousand farms and confiscate cattle farms, various implements, buildings for the amount of 95 million rubles, 860 thousand people were deported to Siberia and the Far North.

The Holodomor of 1932-1933 was a terrible tragedy of the people of Ukraine. It was aggravated by the fact that during the 1930s and 1931s, 780 million pounds of grain was exported from the country, and the harvest of 1932 was 12\% lower than in the period 1926-1930. Any attempts to use the grain were considered as sabotage. In the governmental resolution of August 7, 1932, «On the Protection of the Property of State Enterprises, Collective Farm, and Cooperation and the Strengthening of Public Property» it was proclaimed that all collective-farm property was state-owned. Having increased $44 \%$ of the grain procurement plan in Ukraine in 1932, Stalin J. condemned the peasants to a hunger, which led to the death of 5 to 6 million people. On January 19, 1933, instead of a surplus appropriation system, a new system of mandatory procurement was introduced in the form of taxation of squares planted. March 17, 1933 officially introduced by the government decree of workdays, and the «Charter» in 1935 approved the norms of production and wages. Previously, one working day (1930-1931) was $300 \mathrm{~g}$ of grain ${ }^{16}$.

The Agricultural Tax Act of September 1, 1930 established a progressive income tax on farmland plots instead of taxation on the income they received on weekdays. The movement in agriculture branch made it possible in December 1934 to abolish the card system of food products in the cities. This achievement was facilitated by products grown on farmland, the percentage of which in Ukraine amounted to $30 \%$ of $21.5 \%$ of all agricultural production in the USSR. In addition, both first five-year plan (completed for «four years and three months») and the second did not provide a significant increase in grain yield. If in the first five-year plan 735.6 million c. were received, then the second - only 729 million c., or less than in the time of the NEP.

The Soviet-German war of 1941-1945 brought huge losses to domestic agriculture. A significant part of the property of the farms has

\footnotetext{
${ }^{16}$ Панченко П. П., Мельник Ю. Ф., Вергунов В. А. Аграрна історія України. Навч. посіб. Київ : ВЦ «Просвіта», 2007. С. 276-288.
} 
been evacuated to Central Asia, Azerbaijan and Georgia, which is 8508.3 thousand heads, or $47.5 \%$ of public cattle, 187 state farms, 3,182 tractors and 3.5 million people. At the beginning of 1943, the mass exile of occupants from Ukraine took place. In the spring of 1944, the crop area of Ukraine was restored by $65 \%$ - in comparison with the prewar period. Average grain collection reached $10.8 \mathrm{c} / \mathrm{ha}$ of grain (in $1940-14.6 \mathrm{c} / \mathrm{ha}$ ), which enabled to fulfill the state plan of grain procurement. Retreating, the occupiers took from Ukraine to Germany 9 million tons of grain, 400 thousand tons of sugar, 950 thousand tons of oil, 622 thousand tons of meat products, 108 thousand tons of oil, 2 million 500 thousand tons of livestock feed. 27,910 kolkhozes, 872 state farms and 1300 MTS were demolished. The occupants seized 56 thousand tractors, 24 thousand combines, 16, 9 million heads of cattle and pigs, 7, 8 million sheep and goats, and 3, 3 million horses. Out of the total amount of material damage 285 billion rubles, $31 \%$ falls on agriculture. The reconstruction of the village took place in difficult conditions, and especially in terms of providing the material and technical base. As a result, an increase of 1 million hectares of cultivated land in 1945 did not lead to an increase in average yields. There were 27493 kolkhozes, 784 state farms and 1277 MTS in Ukraine at the end of 1945. The following year the process of merging small collective farms into large farms began, which became massive in 1950. Amount decreased from 33 653units in 1950 to 16506 units by $1951^{17}$.

Great harm to the Ukrainian village brought the "third Soviet famine" of 1946-49, which took 1.2 million human lives, as a result of another drought. It led to the death of 550 thousand hectares of winter crops, or $20 \%$ of the total sown area. Despite 95 thousand tons of food grain that came to the republic, $34 \mathrm{~kg}$ of grain per one Ukrainian did not serve to resolve the situation, especially against the backdrop of increased grain exports of the USSR to the newly established "socialist camp" countries. Positive changes took place after Khruschev's speech in September 1953 at the Plenum of the Central Committee of the CPSU. Investments in agriculture have increased, which doubled this figures of 1933-1953. This gave an opportunity to technically rebuild the village. Thus, in 1955, on the fields of Ukraine, 50,7 thousand combine harvesters operated against

\footnotetext{
${ }^{17}$ Панченко П. П., Кириленко І. Г. Вергунов В. А. Аграрна історія України : еволюція соціальноекономічних відносин : навч. посіб. Вид. доп. і перероб. Київ : Аграр. наука, 2014. С. 386-412.
} 
33,4 thousand in 1940, and by 1960 their number increased to 64,8 thousand units, which allowed in 1958 to hand over 552 million pounds of grain at a yield of $19.9 \mathrm{c} / \mathrm{ha}$.

Since 1959, the process of containment of auxiliary agriculture has taken place, which resulted in lower incomes of rural workers and undermined the state agricultural sector. Since 1959, the process of containment of auxiliary agriculture has taken place, which resulted in lower incomes of rural workers and undermined the state agricultural sector. The widespread introduction of Williams' W. herbivorous system without taking into account the climatic zones has led to a reduction in crops and caused billions of losses to the agrarian sector. The area of winter wheat crops decreased by $31 \%$ in 1963 , or by 5.2 million hectares compared to 1958, with 7.5 million hectares. As a result- 1963 food crisis broke out. Khrushchev's next «innovation» did not help to solve the crisis in March 1962 by using the dominance of the structure of the corn crop area, apparently the creation of 250 territorial collective and state farm enterprises $^{18}$.

The new rise of agriculture in Ukraine took place in 1966-1970, when gross production increased by $21 \%$ with 9,244 collective farms and 1,605 state farms produced from all-Union volumes of $20 \%$ of grain, $59 \%$ of sugar beet, $44 \%$ sunflower, $28 \%$ vegetables and $23 \%$ of livestock products. Capital investments reached 16102 million rubles in 1970, which allowed to bring the number of tractors to 317.2 thousand and 81.2 thousand grain harvesters, as well as 244.2 thousand of trucks. The period from 1966 to 1970 was the third rise of agriculture over the years of Soviet power. The first - $1922-1926$ - when gross production has almost doubled. The second is from 1954 to 1958, when production increased by $50 \%{ }^{19}$. Mostly the success in agricultural production in the third period was achieved due to the fact that in late 1970 in Ukraine, $40 \%$ of its employees were young people under the age of 28 years. Among them: 119 thousand - mechanics, 92 thousand- livestock breeder, 25 thousand agricultural specialists in 100 various majors. This enabled obtaining an average grain yield of 21.4 centners per hectare. The creation of highyielding varieties of winter wheat by scientists also contributed to goal:

\footnotetext{
18 Панченко П.П., Чишко В.С. Украинское село на путях научно-технического прогресса: достижения и просчеты (60-80-е годы). Киев : Наук. думка, 1989. С. 94.

${ }^{19}$ Панченко П. П., Мельник Ю. Ф., Вергунов В. А. Аграрна історія України. Навч. посіб. Київ : ВЦ «Просвіта», 2007. 532 с.
} 
Bezosta 1, Myronivska 808, Myronivska jubilee, Odessa 51, Poliska 70 and others.

The period of 1970's is one of the most difficult in agriculture. It coincided with a marked weakening of the pioneering aspirations, preservation of the principles and forms of management of agricultural production by the party and the state, which lasted until November 1982. Despite an increase to 29204 million rubles investments and the increase in the level of mechanization of milk cows from 55 to $89 \%$, the quality of milking equipment remained low.

The flow of youth into the city became noticeable, and hence the need for specialists. As a result, the profitability of collective-farm production decreased significantly, for example, in 1978 it reached $17.2 \%$. This was facilitated by an increase in the economic burden on Ukrainian lands, which was 3-4 times higher than in Germany and Japan. More than $70 \%$ of the territory of Ukraine (42 million hectares) 35, 6 million hectares was plowed up. Thus, during this period the USSR purchased abroad from 30 to 40 million tons of grain.

At the beginning of the 1980's the agro industrial complex contributed a third of Ukraine's national income, but received only $18 \%$ of centralized capital investments. This led to a decrease in the production of grown crops. Thus, as of 1985, the production of sugar beets decreased by almost 7 million tons, sunflower - 135 thousand tons, potatoes - by 529 thousand tons, comparing to 1980 . In 1988, the republic produced per capita: $86 \mathrm{~kg}$ meat, $68 \mathrm{~kg}$ of milk and $477.5 \mathrm{~kg}$ of dairy products. By 1990, Ukraine produced annually $110-120 \mathrm{~kg}$ of sugar per capita, and its share in the allunion production was $83 \%{ }^{20}$.

In 1989, purchasing prices went down for meat, potatoes, etc. Thus, the real value of pork in Ukraine was 1896 rubles per ton at a real cost of 1946 rubles. As a result, the level of profitability was 3\% lower than required. As of 1989, collective farms and state farms had a total profit of 44 billion rubles, and its processors - 120 billion rubles, means 2.5 times more. All these factors negatively affected the general economic situation of agricultural production. In 1988 the financial debt to the state reached to 14 billion rubles, which made it impossible to implement the «Food Program» adopted in May 1982, which supposed to provide the population

\footnotetext{
${ }^{20}$ Панченко П. П., Кириленко І. Г. Вергунов В. А. Аграрна історія України : еволюція соціальноекономічних відносин : навч. посіб. Вид. доп. і перероб. Київ : Аграр. наука, 2014. С. 412-428.
} 
with food products in accordance with scientifically sound norms. For fulfillment of the task in accordance with the decree of 1985 «On further improvement of management of agro industrial complex», the State Agricultural Enterprise of the Ukrainian SSR has been established, which continued the «best» traditions of the Soviet era with regard to the publication of all kinds of directives and regulations, in 1986 there were more than 3 thousand of those, however it has not solved the food problem for the time of the USSR. 86 resolutions of the party and the government, which 21 times were considered and adopted at the plenums of the Central Committee of the CPSU on agriculture, did not work out.

In 1990, Ukraine's farmers received $37 \mathrm{c} / \mathrm{ha}$, and in some areas the crops reached $45-65 \mathrm{c} / \mathrm{ha}$ at an all-Union level of $18 \mathrm{c} / \mathrm{ha}$. At the same time, in Hungary, these figures were $50 \mathrm{c} / \mathrm{ha}$, and in Holland $60 \mathrm{c} / \mathrm{ha}$. As a result, grain was imported in the country at a price of $150-160 \$ /$ ton. Thus, in 1989, 38 million tons of grain has been bought abroad, spending the amount of 3.2 billion rubles. Mostly feed grain was imported: corn, barley, oats and sorghum, as well as 4.8 million tons of soybean meal and soybeans for a total value of 0.8 billion rubles. Therefore, all Ukrainian agriculture needed to change ${ }^{21}$. They began in December 1990, when the Verkhovna Rada of Ukraine approved the new Land Code of Ukraine as an independent state and adopted the Resolution «On Land Reform», according to which March 15, 1991 land reform was initiated. Another step was the Decree of the Cabinet of Ministers of Ukraine on the privatization of land plots, which, despite all sorts of "obstacles", ended in the late 90's of the last century. Issued on November 10, 1994 by the President of Ukraine Kuchma L. the decree «On urgent measures to accelerate land reform in the field of agricultural production» was blocked by the left-wing forces of the Verkhovna Rada of Ukraine. Other legislative acts should include the adoption by the Cabinet of Ministers of the Resolution on the implementation of the Law of Ukraine "On peasant (farmer's) economy», and in particular the Decree of the President of Ukraine of December 3, 1999 «On urgent measures to accelerate the reform of the agrarian sector of the economy» targeting to realization state agricultural policy, acceleration of the reformation and development of the agrarian sector of the economy on the basis of private property, which in fact gives the countdown the

21 Вергунов В.А., Падалка С.С. Державне управління сільським господарством у вимірі європейської стратегії та глобальної інтеграції України. Історичний нарис $з$ давнини до сьогодення. Вінниця : ТОВ «Нілан-ЛТД», 2017. С. 180. 
return of the main approaches typical of state policy and the events of 1917, or the introduction of better, especially Stolypin agrarian reform.

\section{CONCLUSIONS}

Establishment of the state regulation system and legislative decisions on the management of the agricultural sector was launched in 1894 by the creation of a specialized agency - Ministry of Agriculture and State Property, headed by Ermolov O.S. Substantial influence on the development of the industry has been done by the agrarian reform of Prime Minister Stolypin P., the leading idea of which was to create a land fund and transfer the land to the peasants aiming further farms establishing. The lessons of Stolypin's agrarian reform are following: 1) Without the fullfledged existence of the Peasant Bank, which allocated funds not only for the establishment of farms, but also for the development of the social infrastructure of the village, solving the problem of the provision of its labor resources, it is impossible to carry out agrarian reform in Ukraine; 2) it is necessary to clearly define the size of the land to establish a peasant-farm economy, by waving taxation from its owner during the first 2 to 3 years and determining the amount of taxation after the specified period of management; 3) provide a legal opportunity for the development of various forms of ownership in the countryside: state, cooperative, private, family-labor and give the peasant the right to choose; 4) it is necessary to revive agricultural cooperation in the village (butter-making, corn crackers, oil-mills, mini-bakeries, cheese factories, etc.); 5) in order to ensure that the land does not become the object of speculation, legislatively work out the entire legal mechanism in case of its sale to the population. But the given historical lessons can be successfully used for changes in the agrarian sector of Ukraine as Dokuchaev V. forecasted in 1881: «... when in our agricultural sector there will be a deeper reform that covers all of its people when ... our the agricultural business will be organized on a more correct agricultural and economic basis of knowledge, capital and labor»» and added in 1892 that there is no other way if «... they want to put domestic agriculture on their hard feet .... ${ }^{22}$.

Stolypin P., realizing that due to increased exports of agricultural products in the country it is possible to achieve its economic prosperity, systematically approached the introduction of its own reform. Having

22 Докучаев В. В. Избранные сочинения. Москва : Сельхозгиз, 1954. С. 427-428. 
increased the amount of excise duty on the sale of alcohol beverages, he managed to create an insurance stabilization fund, which, according to his own estimates, was approximately 100 thousand dollars per peasant in the event of any risks from the failures of reform. In addition numerous professional courses, schools and colleges have been opened for agricultural sphere employees, not to mention the network of industrial SRIs, which since 1908 became part of the regional coordinating organizational form, which is valid till present days. As Stolypin's agrarian reform proves that not only legally ensured everything, but also financially, glorifying the Ukrainian peasant farmer all over the world, from any changes and transformations in the countryside it is possible to succeed due to carefully and thoroughly thought-out steps in terms! A huge place in this belongs to local self-government, which should become the driving force of all changes in society, in particular in the countryside.

Beginning in 1894, and especially since June 1917, the leader of the state policy on domestic agriculture continues to be the profile office despite changes in the name (Ministry, General Secretariat, the People's Commissariat and again the Ministry). Its leaders have borne and continue to be responsible for all the transformations regarding the implementation of the state policy towards the Ukrainian village. Many years of research have shown that from June 1917 to the present, there were 57 people. I am convinced that this is not a complete list of all profile ministers, as there is a possibility, especially as regards the period of 1917-1920 (for which there is no significant body of authentic archival documents), when not only three state-building processes with opposing views on land issues and stable aspiration to return the land to the peasants have changed, but also 11 national government units with 6 government courses. The appointed ministers made their own contribution to the formation and development of Ukrainian agriculture. In fairness it must be said that each of them, for objective reasons, became a hostage of his time and the regular reforms of the political system mostly, and, of course, acted accordingly with respect to agriculture in Ukraine.

The Bolsheviks' the Decree on land and the «Regulations of the Central Executive Committee on socialist agriculture» (1919) served as the basis for the further construction of the collective farm system of agriculture in the countryside. After the Holodomor, repression and war, 
the country built a second-largest state-planned economy in the world, which periodically grew and receded, and failed in the late 1990's. Changes in the Ukrainian agricultural sector began with the adoption in December 1990 by the Verkhovna Rada of Ukraine of the new Land Code of Ukraine as an independent state and the adoption of the Resolution "On Land Reform", according to which on March 15, 1991 land reform was initiated. At the present stage of the systemic crisis in the state's economy, it is necessary to take into account and use historical lessons, in particular regarding the principles of the Stolypin reform.

\section{SUMMARY}

The proposed article deals with the main aspects of state policy regarding the development of the agricultural sector in Ukrainian territories in the late nineteenth and early twenty centuries. The main accent is on the quantitative indicators of agricultural production, taking into account the impact of the reforms. It was determined that the construction of the system of state regulation and legislative decisions on the management of the agricultural sector was started in 1894 by the creation of a specialized agency - Ministry of Agriculture and State Property, headed by well-known scientist-agrarian and statesman Ermolov O.S. Substantial influence on the development of the industry has been done by the agrarian reform of Prime Minister Stolypin P., which was conducted in 1906-1917. The harvest of the main grain crops has grown from 2 billion pounds in 1884 to 4 billion pounds in 1911, or $28 \%$. The Bolsheviks' first the Decree on the land and «Regulation of the Central Executive Committee on socialist agriculture» adopted in 1919, served as the basis for the further construction of the collective farm system of agriculture. After the Holodomor, repression and war, the country built a second-largest state-planned economy in the world, which periodically grew and receded, and failed in the late 1990's. Changes in the Ukrainian agricultural sector began with the adoption in December 1990 by the Verkhovna Rada of Ukraine of the new Land Code of Ukraine as an independent state and the adoption of the Resolution «On Land Reform», according to which on March 15, 1991 land reform was initiated. 


\section{REFERENCES}

1. Бок М. П. Воспоминания о моем отце П. А. Столыпине. Москва : Тов. А. Н. Сытин и Ко, 1992. С. 146.

2. Вергунов В.А. Перші Всеросійські та місцеві з'їзди діячів сільськогосподарської справи : організація, напрямки роботи, значення. Історія укр. науки на межі тисячоліть. 2002. Вип. 7. С. 14-15.

3. Вергунов В. А., Коцур А.П., Коцур В.П. Україна та столипінська аграрна реформа:передумови, завдання, здійснення : монографія. Київ : ННЦ «Ін-т аграрної економіки», 2008. 132 с.

4. Вергунов В. А., Падалка С. С. Державне управління сільським господарством у вимірі європейської стратегії та глобальної інтеграції України. Історичний нарис з давнини до сьогодення. Вінниця : ТОВ «Нілан-ЛТД», 2017. С. 180.

5. Власюк П. А. Содружество русских и украинских ученых в развитии сельскохозяйственных наук. Науч. тр. Отделения с.-х. наук Ан УССР. Київ, 1956. С. 3-15.

6. Докучаев В. В. Избранные сочинения. Москва : Сельхозгиз, 1954. С. 427-428.

7. Жан-Жак Руссо. Про суспільну угоду, або принципи політичного права. Переклад з французької та коментарі : О. Хома. Київ : Port-Royal, 2001. 349 с.

8. Завальнюк О.М., Рибак І.В. Новітня аграрна історія України. Кам'янець-Подільський : Абетка-Нова, 2004. 287 с.

9. Закон України «Про стимулювання розвитку сільського господарства на період 2001-2004 рр.». Відомості Верховної ради України. 2001. № 11 (1 берез.). С. 233-237.

10. Історія господарства : Україна і світ : підручник / за ред. Б.Д. Лановика. Київ : Вища шк., 1995. 480 с.

11. Історія українського селянства. Нариси в 2-х томах. Т. 2. Київ : Наук. думка, 2006. 654 с.

12. Коваленко Н. П. Становлення та розвиток науковоорганізаційних основ застосування вітчизняних сівозмін у системах землеробства (друга половина XIX - початок XXI ст.). Київ, 2014. C. 86.

13. Панченко П. П., Кириленко І. Г., Вергунов В. А. Аграрна історія України : еволюція соціально-економічних відносин : навч. посіб. Вид. доп. і перероб. Київ : Аграр. наука, 2014. 536 с. 
14. Панченко П. П., Мельник Ю. Ф., Вергунов В. А. Аграрна історія України. Навч. посіб. Київ : ВЦ «Просвіта», 2007. 532 с.

15. Панченко П. П., Чишко В. С. Украинское село на путях научно-технического прогресса: достижения и просчеты (60-80-е годы). Киев : Наук. думка, 1989. С. 94.

16. Положение о сельскохозяйственных опытных учреждениях. Известия Министерства земледелия и государственных имуществ. 1901. № 29 (22 июля). С. 546-547.

Information about the author: Vergunov V. A., Doctor of Agricultural Sciences, Professor, Academician of NAAS, Director, National Scientific Agricultural Library of NAAS 10, Heroiv Oborony St., Kyiv, Ukraine 
DOI https://doi.org/10.36059/978-966-397-100-1/240-259

\section{THE INTRODUCTION OF STATISTICAL RESEARCH BY PROVINCIAL AND DISTRICT ZEMSTVOS FOR AGRARIAN BRANCHES}

\section{Vergunova I. M.}

\section{INTRODUCTION}

The contemporary significance of the static methods for implementation and development of agrarian research and practice is the main reason for the necessity of studying the historical experience of their introduction in the general course of the history of agrarian science of Ukraine. The relevance of this topic is also due to the lack of learning interdisciplinary achievements of researches of agrarian theory and practice from the second half of the XIX century to the beginning of the XX century and the results of the research of provincial zemstvos that were using statistical methods for agricultural needs.

The study of agrarian branches by zemsky statisticians was an inseparable part of current achievements and relevant scientific research and was conditioning a cooperation with leading statisticians, soil scientists, agronomists, economists, and active participation in scientific events. Therefore, the purpose of the presented work is to study the results of provincial zemstvos that introduced statistical methods in research of agricultural practice on the area of modern Ukraine. The solution of this problem shows the main directions of research of provincial and district zemsky institutions, the results of which were having great importance for the development of agrarian science, identifies the role of research of zemstvo statisticians in addressing the needs of the national agricultural science and practice of the second half of the XIX century - the beginning of the XX century, objectively evaluates the contribution of statistical methodology to the development of agrarian science, and also fills in the gaps in the comprehensive coverage of the history of the formation and development of agricultural science in Ukraine.

The objects of the research are archival documents, zemsky statistical surveys and statistical descriptions of valuation and statistical departments, 
materials from meetings of agricultural societies and other historical sources that reflect the research activity of zemsky authorities within the territory of modern Ukraine in the second half of the nineteenth century. the first decades of the twentieth century, which is directly related to the use of statistical methods for the needs of the agrarian economy.

\section{Preconditions for the Establishment of Zemstvos Statistical Institutions}

The beginning of statistical work in the Imperial Russia was cured from 1837, when the governors were obliged to provide the Ministry of Internal Affairs with annual statistical and economic data on the state of the province collected by provincial and regional statistical committees, which were organized in 1835 . The work of the statistical committees was initially regulated by the Statistical Department at the Ministry of Internal Affairs, and from 1875 - the Central Statistical Committee under the Ministry of the Interior. For the first decades, committee officials did not have knowledge about methods for collecting and processing statistical data but had many other duties. The intensification of the work of committees within the territory of modern Ukraine (as of 1853, there were Katerynoslavsky, Kyiv, Odesa, Poltava, Tavrichesky, Kharkiv, Chernigiv ${ }^{1}$ ) took place after their reform in 1859 , when the members with relevant knowledge and experience were introduced into the committees. The updated committees developed statistical information for the governors' reports.

Gradually increased the number of performed state statistical work. Among the information that was served were data on the state of agriculture, industry, estates of the province. But information gathered locally county police departments, county councils, clergy, parishes, because they were often of poor quality. The main tasks of the provincial statistical committees were the work of streamlining and analyzing statistical information about the province.

In 1881, the Central Statistical Committee for the first time recorded the crop area for some crops and calculated the level of yield per unit area, which led to the emergence of new information about crops and crop yield. The gathering of information about the crop area lasted for two years,

\footnotetext{
${ }^{1}$ Елисеева И. И. История статистики. М. : Финансы и статистика, 1990. 296 с.
} 
another year processed data and checked by comparison with the information of the land census in 1877. In spite of the slowness of these works, it was possible to organize statistics on yields from 1883. Since 1881, the crop statistics were collected by the Department of Agriculture and Rural Industry of the Ministry of Agriculture and State Property, but these materials concerned only crop yields in subordinate and privateownership lands and were often not reliable.

Introduced "Regulations on provincial and district zemstvos institutions" (1864), zemstvos as bodies of local self-government should deal with food for the population, economy, insurance, etc. The main source of funds for their activities was local taxes, which were collected on the basis of the value of the property and its profitability. Therefore, the zemstvos needed data on local farms, which the Central Statistical Committee did not receive.

Zemstvos began to form their own statistical organizations and to invite statisticians to process and analyze data which in the beginning were collected through correspondents. But the inadequacy of the information provided gave the statisticians the task of improving the collection of data. The need to provide accurate and reliable information for solving the issues studied by zemstvos led them to the formulation of the task of studying economic life, the state and prospects of the development of villages. In a short time, statistics were not limited to the definition of land yields, and data were collected seconded to the counties on questions from the research program.

Provincial and district zemstvos admitted that the level of development of the agrarian sector, as a leading, is of great importance for the further development of society, so the main focus in the studies of rural statisticians devoted precisely to agriculture. At that time, agricultural statistics had the following structural trends: land (territory, climate, soils, land tenure, land use, land prices), rural population (size, composition, etc.), agriculture and livestock farming (land, crops, equipment, processing, fertilization, crops, harvests, cattle), trade in agricultural products (prices, movement, etc.) ${ }^{3}$.

2 Ковальченко И. Д. Аграрный строй России второй половины XIX - начала XX в./ И. Д. Ковальченко ; Историко-филологическое отд. РАН. Комиссия по наследию акад. И. Д. Ковальченко. М. : РОССПЭН, 2004. 504 с.

${ }^{3}$ Фортунатов А. Сельскохозяйственная статистика Европейской России. М. : Типо-Литогр. Тов. И. Н. Кушнеров и К., 1893. 250 с. 


\section{Study of Soils by Zemsky Statisticians}

The study of the soils of the provinces became the first task in the works of zemsky statisticians. Moreover, the study of soils was a component of valuation and statistical work, so they performed work on this task from the beginning of the activity of zemstvo statistical institutes to the liquidation of zemsky institutions. The main result of these studies was the maps of soils of counties and provinces.

The first such map was a map of soils of Novozybkivsk district of Chernihiv province, created by V.E. Varzer (1880). The map, according to a statistical research, reflected the diversity and complex distribution of soils in the county. It gave an opportunity to substantiate yields, explaining the obtained values of average crops, first of all, by the type of soils. Territorial distribution of the main types of soils V.E. Varzer led to four categories (black soil, gray earth, average earth, bad land, which had a division into two varieties) indicating that the position (mountain, bottom), ground, etc. can produce different effects on one type of soil.

As a result of studying the soils of the Borzny county of Chernihiv province, the statisticians have characteristics of soils regarding yield and moisture production. After the construction of different types of soils in the countryside, they indicated the villages in which dry or wet weather required for the best crops.

It was in the Chernihiv province that data on yield statistics began to be grouped according to the established soil strips and to show the average yield of soil varieties in the county. The idea of using grouping by type belonged to D.P. Zhuravsky. In his papers "About the sources and use of statistical information" (1846) and "The Statistical Description of Kiev Province"5 (1852), he built tables for a combination of two groups and used methods of statistical analysis.

Developing the ideas of D.P. Zhuravskii, statisticians of Chernihiv region widely used groupings from the first studies. In the description of Novozybkivsky county V.E. Warzer conducted a statistical study of soils for the first time based on a survey of the owners and certain territorial units. The results of such study allowed A.P. Shlykevich to make a map of the provinces of the province.

\footnotetext{
4 Журавский Д. П. Об источниках и употреблении статистических сведений. К. : Тип. И. Вильнера, 1846. 212 с.

${ }^{5}$ Елисеева И. И. История статистики. М. : Финансы и статистика, 1990. 296 с.
} 
Although according to the statisticians A.S. Semyanovsky and A.P. Shlykevich, the classification of soils was imperfect (occurred in the review), the division into soil bands was of great importance for the weakening of the influence of chance on the general conclusion in the study of crops. The conclusion of the statisticians and their widespread use (in the form of data grouping for further research - the analysis of connections, allocation of type) substantiated the idea of typological grouping, which is widely used in modern researches of agrarian experimental data.

The statisticians of Chernihiv province represented aggregated tables containing the values of average yields drawn by the allocated digits, where the notes indicated the types of soils, crop rotation. Such tables were built on the basis of the division of counties on homogeneous soil bands by statistical study of soils and the grouping of yield data for established soil bands, by which the average yield of the soil varieties of the county was calculated. It was the basis for calculating the yields of each field, calculated according to the proportion of soil types.

Using the development of V.V. Dokuchaev, statisticians of Chernihiv province examined the grounds of the province and identified six main types of soils, got their characteristics and determined the territorial distribution, namely, the soil areas (for example, in Konotopsky district A.S. Semeanovsky and A.P. Shlykevych distinguished three soils regions). Results of research of soils of counties and division into subsoil areas allowed A.P. Shlykevich to make a soil map of the province in the late 1880's.

Too small landholdings in Chernigov region became the reason for the implementation of zemstvo statisticians detailed soil and geographical surveys of counties. After consultations with the leading statisticians of the country (M.F. Anensky, M.O. Kablukov, M.M. Kislyakov, V. Ostrovsky, O.V. Peshekhonov, F.A. Shcherbina) the decision about detailed soil studies in the province was approved by the provincial zemsto in 1902. The presence, since 1901, in the estimated-statistical bureau of Chernihiv provincial zemstvo the soil scientist-statistician (B.B. Polinov) allowed to perform such works. The result was the receipt of soil maps in a 1-verst measure - the first card was created by V.E. Varsar in 1903. Then soil maps were made in the 1-verst dimension of Nizhyn, Kozelets, Oster, Chernihiv, Sosnitsky, Horodnya, Borznensky districts. 
The significance of the works of zemsky statisticians on the study of the soils of the provinces is partly highlights by V.A. Vergunov. He points out that the first textbook on soil science in Ukrainian language of A.G. Ternichenko (1919) was built on the results of zemstvo statistical studies. In the their study V.A. Vergunov also gives an estimation of the outstanding soil scientist G.G. Makhov, which states that the study of soils evaluatived-statistical bureau of Chernigiv provincial zemstvo in 1903-1911 was "most significant for the establishment of soil science in Ukraine"

In Poltava region soil studies also became an important area of activity of zemsky statisticians in studying the province. According to the information received on the type of soils and other soil characteristics for a particular area, the statisticians performed the division into stripes and districts (for example, the Mirgorod district was divided into three lanes along the direction of the flow of the Psel and Khorol rivers, and, according to the general character of the terrain into four districts).

If at first the statisticians of this province received the characteristics of the soils in the counties on the ground map of European Russia, issued by the Department of Agriculture and Rural Industry, taking into account the features of the soils of the areas identified by the observations of local hosts, then a few years later they used the results of soil studies by local soil scientists. So, in Kremenchuk district, which had different quality soils and was divided by statisticians into four natural areas, they considered the soil characteristics given by V.V. Dokuchaev and M.I. Arandarenko. After the end of the study of the counties for obtaining soil characteristics under the guidance of V.V. Dokuchaev, provincial statistics showed that the type of soils had a "significant effect on the system of cultivation and change of bread"7. The statisticians of Poltava region have divided the province into 26 districts based on the natural characteristics of the areas, which included the soil. Due to this, they received the district map of the province (1900), which fully corresponded to the hypsometric and soil maps of the soil study of counties under the guidance of V.V. Dokuchaev.

\footnotetext{
${ }^{6}$ Вергунов В. А. Історя грунтознавства в Україні: проблеми і методологія шляхів вирішення. Вісник Харківського національного грарного університету ім. В. В. Докучаєва. 2006. № 7. С. 20 -37.

${ }^{7}$ Сборник по хозяйственной статистике Полтавской губернии. Том Х. Переяславский уезд. / под ред. Н. Кулябко-Корецького. Полтава : Типо-литогр. И. А. Дохмана, 1890. 286, 482 с.
} 
The introduction of the division into types of soil areas by the statisticians of Katerynoslav province made it possible to study the size of the density of seeding of the main crops depending on the type of soil.

Zemsky statistics of Kharkiv region carried out the study of soils, considering the geological structure and the presence of soil moisture. Their work in Volchansky district allowed in 1882 statistician I. Klingen to study the movement of heat in the soil and its distribution by periods of the year. At the beginning of the XX century, the statisticians of Kharkiv provincial zemstvo also made classification of soils based on the physico-chemical characteristics provided by soil scientists. According to statistical surveys of the province, they divided the territory into three areas by the amount of precipitation (northwest, central, south-east) set up and have solved the problem of the smallest number of experimental fields for the province.

The statisticians of Kherson region also carried out studies on the establishment of types of soils (identified 7 types of areas in the province). Considering the importance for the province of the possibility of accumulation and preservation of moisture in the zone of aeration of plants, they studied the issue of soil moisture accumulation and soil yield (for example, performance of the analysis of the moisture content of different layers of soil depending on its cultivation and on weather conditions in the long-term experiments of the Kherson experimental field). In reviews from 1910 statisticians provided statistical data on the content of nitrogen, leachate, sulfuric and phosphoric acids for all seven types of terrain.

The statisticians of Tavria provincial zemstvo at the beginning of the XX century, according to the survey of the counties, also identified the ground areas. In Perekopsk district, they additionally conducted a soil study to allocate the ground area (Prisivasnaya I-a), which occupied the position between the loams of the central zone of the county and a strongly saline soils of the prysyvashna ground strip. In 1907 the statisticians of the province finished the creation of soil maps of counties on the basis of soil studies. Further works on the study of soils were as a supplement and amendments to previously obtained soil maps (for example, maps of Yevpatoriya district). Measurements and laboratory analyzes in these works were done by the soil scientist, and their results were statistically analyzed.

The statisticians of Podilsky provincial zemstvo in cooperation with the agronomist O.I. Naboki and soil scientists also engaged in the construction of a soil map of the province. From 1910, they statistically 
processed a large amount of data from the laboratory study of collected samples to study the "morphological and physical and chemical properties of all types and subtypes of the soils" $"$. But military actions interrupted work, therefore the reduced version of research became the basis of the soil map of the province only in 1915.

The results of zemstvo statistician studies on the scientific research of soils indicate the high level of work, which was often recognized as a model, and turned into "bricks" for the further development of soil science and agronomy.

\section{Zemstvo's Statistical Investigations in the Field of Agriculture}

According to statistical descriptions of the provinces of the territory of modern Ukraine, the statisticians examined the land, the climate, cropping systems, crop yields. They studied the question of the correct determination of the value of yield, pointed to the need to obtain accurate soil and climatic data that affect the yield of land, etc. For example, P.P. Cervinsky, A.A. Rusov, V.E. Warzer was the first to develop a method for calculating average crop yields in the description of Borzny district (1877). Such a technique has not existed and their method has been widely used in other provinces. The statisticians of Chernigiv provincial zemstvo began to study the size of the crop and its quality, depending on the types of soils. They have developed a method for extracting the average yield for areas from the data of the distribution of soil varieties and their crop yields and introduced it in the review of Kozelets county. In this review, introduced consideration of variations in the values of crops for the main crops. They showed the impossibility of using the term of "natural yield", which was widespread at that time, but have led to the use of the concept of crop yield.

Using the achievements of the statisticians of Chernigiv region, the statisticians of Tavria provincial zemstvo calculated the average yield and its fluctuations for the main crops in the counties for the years 1881-1888. They found that the average yield of all breads decreased in the direction from east to west in the mainland and from south to north in Crimea by

\footnotetext{
${ }^{8}$ Материалы по исследованию почв и грунтов Подольской губернии. Том 1. Результаты полевых и лабораторных изысканий 1914 и 1915 г.г. / Под ред. Проф. Набоких А. И. Одесса : Типогр. Акционерного Южно-Русского Об-ва Печатного Дела, 1916. 268 с.

${ }_{9}^{9}$ Материалы для оценки земельных угодий, собранные Черниговским статистическим отделением при губернской земской управе. Том V. Козелецкий уезд. Чернигов: Губернская типогр., 1882. 75,101 с.
} 
distribution of soil types and moisture. They performed a study to find out whether or not conditions were favorable for the production of hay, winter and spring breads for 19 years (1867-1885). According to the results of this study, the classification of yield levels was presented. Calculating the average yield of winter wheat and analyzing the dynamics of its change allowed them to conclude that "improvement of soil cultivation" 10 in the province.

According to the studies of grain yield statisticians of Kharkiv province found that the crop declined from northwest to south-east and reached a difference of $140 \%$. They explained this by a large difference in soil and climatic conditions and proposed to use normal average yields in the counties to obtain the characteristics of the crop in the province for the year.

The statisticians of provincial zemstvos from the end of the XIX century constantly studied the impact on soil yield, climatic and weather conditions, the time of the beginning and the end of sowing and harvesting of different kinds of crops, and also how these terms change depending on the weather. For example, in the description of Volchansky district (1882), the statisticians studied the climate characteristics of the district (for which the long-term temperature measurements, winds, sizes and rainfall distribution throughout the year, climatic characteristics were used), and the movement of heat in the soil, its distribution for periods of the year. This allowed them to study the dependence of the time of maturation of bread crops from soil and topographical conditions, the amount of heat and moisture, the time of sowing. Subsequently, for the study of weather effects on crops, statisticians of Kherson province used numerical data from Odesa and Mykolaiv meteorological observatories, calculated the temperature and precipitation values averaged over the month, the monthly maximum and minimum, the average for the seasons and the average annual, and the first submitted the scientific characteristics of the climate of the province. At the beginning of the XX century, all agricultural reviews of zemstvos began with a detailed description of the state of the weather. The statisticians counted the average temperature, precipitation, and estimated the weather for agriculture this year. Data about temperature and precipitation began to be supplied by measurements of meteorological and rainwater stations, special observation points. For

\footnotetext{
10 Сельско-хозяйственный обзор Таврической губернии за десятилетие $1899-1908$ г.г. Симферополь : Типогр. Таврического Губернского Земства, 1911. 167 с.
} 
example, in Yelisavetgrad county in the description of 1911, there were data from two meteorological stations and 17 observation points, and in 1912 the data was processed according to the data of 4 meteorological stations of the county and 26 observation points. The data on average temperatures and precipitation for Kherson province statisticians were taken from the data of 13 stations of the main physical observatory and many rain-storied stations. The zemsky statisticians of Tavria province calculated the average temperature for months, seasons according to data from 12 meteorological stations (in 1889 they had data for the period from 4 to 52 years).

On the basis of the statistics introduced by the statisticians the concept of the normal value of the indicator and statistically obtained normal values of weather factors, the statisticians of Kherson province began to analyze deviations from the norm of indicators, fluctuations of temperatures and precipitation, measurements of freezing of the soil. The large uneven precipitation in the province for seasons and their character, which were discovered, contributed to the study of the influence of rainfall on the value of crops of different cultures, considering other weather factors. The statisticians of Tavria province in their works analyzed the average temperature by months, seasons for comparison of the provinces. Taking into account the climatic specifics of the province in the data about the precipitation, they gave information about the time and amount of precipitation. They submitted distributions of average values of precipitation for months and seasons, measured at 8 locations in the county. The obtained statistical distributions allowed to prove that the amount of annual precipitation in the province was "sufficient for agriculture" 11 , but the precipitation was distributed very unevenly, which had a very negative consequence for the harvest. The statisticians carried out an analysis of data relating to seeding of winter, spring cereals, by district, county, province. They calculated the average time of sowing crops for a rather long period (for example, 9, 12 and other years). By analogous method, they performed a statistical analysis of conditions for growing crops, harvesting. From the 1890's, statisticians of Kherson province studied fluctuations in yields in counties and isolated areas based on developed techniques. This allowed them to prove that the climate

\footnotetext{
${ }^{11}$ Сельско-хозяйственный обзор Черниговской губернии за 1913 г. Год 10-й. Чернигов : Типогр. Губернского Земства, 1915. 74, 239 с.
} 
conditions have an impact on the results of agricultural activity, and statistician B.Yu. Troyanovsky, after receiving data from 13 meteorological stations in Odesa region, the average, maximum, minimum values of temperature and precipitation (in months and years) and their comparison with the data of long-term observations, justify the presence of droughts. Using of statistical methods and groupings developed by statisticians of Chernihiv and Poltava allowed the statisticians of Katerinoslav province to introduce the division of counties into climatic layers. The obtained division corresponded to a significant difference in the time of the implementation of the same field work in different layers (the difference was up to 7-8 days).

The results of statistical research of the territories of Kyiv region, Volyn and Podillya at the turn of the XX century, namely the distribution of agricultural area of the South-Western region of the country for lands, allowed statisticians T.I. Osadchy to propose the division of territory into areas on economic grounds. The division was used by zemstvo statistical institutions of the respective provinces, established in the early XX century, and, like division into districts made by other provinces, was necessary for the regionalization of Russian Empire.

As for the study of the productivity of the statisticians of zemstvos in the first decades of its activities formulated and used the concept of "natural productivity of land". Thus, the statisticians of Chernihiv zemstvo under the yield of land designated understood "the average yield of rye or spring crops on the tithing of the average quality for the whole dacha, in the amount that most often was on average for the last 3,6 or 12 years $" 12$. Information on the average crop was taken in the presence of numerous, different sources of receipt of data indicated for the average degree of culture, for the average or well-known for the quality of the soil type and the average year for climatic and soil conditions, or were the result of a general reflection about the average yield for the last decade. From the beginning of the $1880 \mathrm{~s}$, according to these data, they began to study the influence of the sowing density per yield of the crop.

Accumulation of information about harvests of the main crops from 1883 allowed statisticians to consider the task of assigning average yields of crops and average crop yields. As a result of processing and analysis of

\footnotetext{
${ }^{12}$ Материалы для оценки земельных угодий, собранные экспедиционным способом по программе бывшего Статистического Отделения при Черниговской Земской Управе. Новозыбковский уезд. Чернигов : Губернская типогр., 1880. 62, 79 с.
} 
a large amount of data, they obtained average yields for different types of farms for counties and provinces. Technical difficulties in determining the average yield of land were in the southern provinces, where often occurred droughts. Thus, the statisticians of Kherson region indicated that for the determination of the average yield of the land we need to have observations and exact records of "not less than 10 years for all the breads"13, grown in different parts of the county. Subsequently, they proved that for the province this period should be increased. With the accumulation of data on the yield the statisticians began to make a comparison of the current harvest of the main bread with the harvest over a long period of time (for example, 23 years in 1909, 25 years in 1911, etc.) for the analysis of the level of the main cereals crop and farming culture.

In the early 1880s, statisticians of Chernihiv region in the study of crop rotation on the basis of taking the grouping by degrees started zoning crops. Thus, in the study of Kozelets district, they received the distribution of the main spring crops, which became the basis for the zoning of crops.

The constant use of grouping in zemstvo statistical studies has become the basis for the introduction of consolidated tables for the analysis of various agricultural tasks. If initially, with their help, they only analyzed the yield of rye and wheat in different types of farms, counties, then, in the early XX century, the statisticians compiled tables with data about the size and quality of the main bread crops per year, depending on the soil groups and districts divided into provinces and counties for all types of farms. From these tables it was possible to see which parts of the province or areas are very different in terms of yield, and to analyze what factors have affected the outcome.

Showing the difference in the levels of yields statisticians of Poltava and Kherson provinces proved that the reasons for this are: carefulness, timeliness of cultivation, better seed and varieties of crops, the influence of precursors of sowing. It was these reasons that they considered as the main ones in terms of equality of soil conditions and precipitation. The most important of the effects on the harvest recognized the precipitation, namely humidity of the soil (the method of cultivating the field affects the preservation of moisture in the field). Showing by means of statistical studies that the accumulation and conservation of moisture by appropriate

${ }^{13}$ Материалы для оценки земель Херсонской губернии. Т. 6. Херсонский уезд (статистико-экономическое описание уезда)/ Сост. Стат. Отд. при Херсон. Губ. Зем. Управе. Херсон : Тип. О. Д. Ходушиной, 1890. XVIII, 458, 134 с. 
soil treatment is essential for plants, statistics of Kherson province in the early XX century investigated the possibilities of its accumulation in the soil layers.

The study of crop rotation during the investigation in Konotopsky district allowed the statisticians to obtain the main crop rotation and, based on their analysis, to come to the conclusion: "the lack of normal steam cultivation and large land depletion" 14 is the reason for the land contamination and much less harvests. Similar conclusions were obtained from statisticians of Poltava province.

The statistics studied the distribution of the sown area of landowners and peasants by major cultures in the counties of the provinces and the selected areas. Performing the analysis of the revealed distributions, they received their compliance with the soil and climatic conditions of various parts of the province.

In the study of the proportions of crops of statisticians of Poltava province showed the certainty of the division of cultivated area used by the system of agriculture. Subsequently, the statisticians of Tavria province showed that the distribution of the sown area by crops strongly characterizes the general direction of the economy, the replacement of one culture with another indicates the transition from one system of arable land to another. The division into four districts of the territory of the province, which was conducted on geographical grounds, also discovered the patterns in the received proportions of crops (for example, due to weather differences).

In the study of farming systems, statisticians examined the introduction of crop rotations for various types of land tenure. They proposed different schemes for crop rotation based on statistical study of land exploitation methods. The statisticians of Kherson province discovered: climatic and soil conditions influenced the turnover of fields; lengthening the processing period contributed to the introduction into the system of crop rotation of potatoes and corn.

The statisticians of Poltava province studied the main places of cultures in relation to their predecessors. They showed that the natural conditions (presence of saline soils, sandy places) affect the field crop management and the change of bread crops. According to the results of statistical research of farming systems, they showed the possibility of

\footnotetext{
14 Материалы для оценки земельных угодий, собранные Черниговским статистическим отделением при губернской земской управе. Том VI. Конотопский уезд. Чернигов : Земская типогр., 1882. $62,93 \mathrm{c}$.
} 
obtaining a pre-calculated crop rotation, and the methodology developed by them had a wide introduction in branch scientific works. The statisticians in the annual agricultural surveys considered the main types of bread crops, provided their general characteristics, advantages, disadvantages. The statisticians of Kherson province introduced an analysis of varieties of main bread crops. For the first time, the analysis was carried out for several varieties of main bread crops grown in 1897-1898. As a result, it was discovered that the variety of spring wheat "ulka"15 was increasingly distributed, which proved to be more productive. In the 1910s, statisticians of Kherson region already covered many varieties of rye, spring and winter wheat, oats.

In studying the methods of cultivating land for main crops, the statisticians conducted the division into groups regarding the methods of cultivating the land for winter and spring crops, depending on the properties of the soil in localities (for example, the presence of viscous soil) and the agricultural tools used.

From the end of the XIX century, the statisticians explored the technical aspects of farming: the use of tools to perform various operations in the process of growing crops, taking into account the soil conditions (preparation of arable land for sowing) the action of plowing plow species, harrows and the like; dates of agricultural work for various grain crops. Thus, the statisticians of Kherson province showed that a great unevenness of the crop was not only due to the lack of sufficient and timely rainfall, but also from the cultivation of soil and crop rotation. Based on studies of arable land, analysis of crops, the rural economic system, statisticians of Poltava region, and subsequently other provinces, concluded that "trial field system is not effective for the population" $"$, it is necessary to move to more intensive farming systems.

The statisticians of Kherson province revealed that without using manure and fixed crop rotation, the owners focused on soil cultivation and selection of the field. This led to their study at the end of the nineteenth century. methods of cultivating and using lands, studies of the dependence of grain yield for various types of fields and methods of cultivation, allowed to prove the importance of a thorough tillage.

\footnotetext{
15 Статистико-экономический обзор Херсонской губернии за 1898 год. Херсон : Паровая Типолитогр. О. Д. Ходушиной, 1900. 300 с.

16 Дувин С. Гадячское районное опытное поле. Полтавские агрономические известия. 10 авг. 1913 г. Полтава: Типо-Литография И. Л. Фришберга, 1913. С. 16.
} 
The statisticians of Poltava Zemstvo on the information about grain yields proved the advantage of plowing the land. They showed that the crop yields for the use of the wooden plow was kept at an average height, not even in the best years of such size as when using a plow. They are studying for plowing, processing of the land, plowing depths by plow. In the description of Lokhvytsky county, they showed the connection between the use of advanced and complex agricultural machines with the achievement of higher yields of crops. In the description of Lokhvytsky county, was showed the connection between the using of advanced and complex agricultural machines with the achievement of higher yields of crops.

The gathering of data for county inspections about the presence of fertilization fields at the beginning of the XX century turned into a study of the influence of fertilizer on the yield of crops, and the statisticians of Chernihiv and Poltava provinces set the task of studying the influence of soil conditions for fertilizin. The statisticians of Katerinoslav province investigated the effect of precipitation on fertilizer results, the dynamics of fertilizer action, types of fertilizer.

The work of statisticians was also important for the implementation of collective experiments of zemstvos. For example, statisticians of Kharkiv province in the collective experiments analyzed data on the study of the effect of mineral fertilizers under different conditions (weather, soil) and in the initial tests of varieties.

During the years of the work of statistical Zemstvo institutions the programs, methods of data collection and processing were continuously improved, which allowed to consider more difficult questions. If in the first decade of their work achievements were the introduction of groupings, consolidated tables, then subsequently offered a methodology for calculating average yields of crops, and in the early XX century statisticians began processing and analyzing the data of collective experiments, experiments of agricultural societies, where they studied the task of rational organization of agriculture, contributed to the development of the methodology of agricultural research. The statisticians showed that the amount of fertilizer, the degree of suitability of the means of labor, the method of farming are significantly different in different farms, but in each locality we can establish a typical farming system, the average amount of fertilizer, the average suitability of the funds. Accordingly, income, defined by the average (normal) value of all 
the impacts, they called the "average income"17. The statistics of the Chernihiv province showed that the average income varies quite slowly, therefore the value determined by the survey may be its norm during a certain period. They developed methods for calculating gross profitability of arable land and proved that without data on local farming systems and crop rotation, without the information on the local systems of agriculture and crop rotation, without the data on the proportion of crops, fertilizers can not determine the gross profitability of arable land, and without information about the technique of cultivation can not count the cost of cultivation.

We can see high scientific level of statistical research of zemstvos in an attempt to organize farms with a predetermined level of economic productivity in Poltava province. This task solved in cooperation with the Poltava Agricultural Society, which developed the organization of the estate for the estate in order to obtain the highest permanent income. As a result of the estimated economic assessments of various branches of agriculture, the statisticians concluded that farms needed a reorganization. It should consist in the fact that "feed will be produced in the fields"18. This will expand plowing for bread crops and at the same time increase the number of productive livestock. As a result, in conditions of rising rents and an increase in the population, it will be profitable to introduce a more intensive system, which requires intensive soil exploitation, but will give high payments on invested capital and labor. In coopperation with the Poltava Agricultural Society, statisticians also showed the obtaining precalculated crop rotations.

Statistics of Kharkiv province collected data on the results of the use in 1908 of the rolling seven-rowed sowing machines of 13 agricultural societies of the province, according to the processed data, proved that there was a saving on the use of ordinary crops, which was reflected in saving the seeds and obtaining higher yields. Their confirmation of a significant increase in yield when using the seeder (for a large amount of statistical data) allowed to scientifically finalize the issue of the advantage of ordinary seeding and was of great importance for its introduction into use.

\footnotetext{
17 Червинский П. П. Земледельческая программа, приспособленная к собиранию сведений для оценки земледельческих угодий. Чернигов : Тип. губернского земства, 1881. Вып. 1-4. 26 с.

18 Дувин С. Гадячское районное опытное поле. Полтавские агрономические известия. 10 авг. 1913 г. Полтава: Типо-Литография И. Л. Фришберга, 1913. С. 16.
} 


\section{CONCLUSIONS}

The main achievements, which had an impressive impact on the future development of agrarian science, are shown as a result of analysis of statistical research made by zemsky staticticians for agricultural branches. In the direction of studying the soils staticticians received the first maps of the soils of counties and provinces. For densely populated areas like Chernihiv province the maps were 1-verst measurement. These maps had a high importance for practical and research agricultural activity in the first decades of XX century, especially for soil science.

In agricultural task's analysis zemsky statisticians studied actual issues: the definition of the magnitude of land productivity; the effect of soil types on the level of crop and its quality; obtaining characteristics of climatic and weather conditions; the study of systems of arable land, crop rotation, varieties of sown bread, methods of cultivating land for main crops, the impact on fertilization on yields of crops, the search for ways to restore the fertility of lands; etc. As a result of these studies, statisticians offered a method for determining the value of crop yields that was widely used in agrarian science and practice. They set up and began to study the important task for science: how to determine the dependence of yields and its quality on the types of soils. They introduced the concept of normal average yields solving this problem.

The achievements of zemsky statisticians were important for the development of agricultural science in representing the characteristics of the climate, the zoning of the crops, as well as recommendations for the transition from a trial field system to more intensive systems of arable farming. Statisticians proved that the system of arable land and bread change is influenced by natural and soil conditions, showed the possibility of obtaining a pre-calculated crop rotation and proposed sound crop rotation schemes.

Zemsky statisticians began to study and to analyze varieties of basic breads and methods of cultivating land for them, a complete sequence of operations and technical aspects of cultivation of bread taking into account the soil conditions and using the statistical data. Studying the ways of fertilizing the fields became a statistical investigation of the impact of fertilizer on the yield of crops.

Statisticians made a zoning of territories, which was important for the future construction of approaches to regional management of agriculture, 
according to natural and economic conditions as a result of statistical and economic study of various types of farms. The statisticians proved that the crops are the general result of action: land, labor, livestock, working capital, etc. It was proved that it is impossible to determine the gross yield of arable land without information about the systems of arable farming and crop rotation, the proportions of crops, fertilizers and it is also impossible to calculate the costs of cultivation without data on the technique of arable farming, methods and techniques of culture. Their methods of calculating the yields for different systems of the economy and the selected areas allowed them to implement a comparative analysis of the yield of crops and the study of the economic feasibility of crop rotation and profitability of cultivated varieties.

\section{SUMMARY}

It is presented an analysis of agricultural research from the second half of the XIX century to the beginning of the XX century by the statisticians of the provincial and counties zemstvos on the territory of modern Ukraine. Different directions of statistical work of zemsky statisticians are considered and their main achievements, which had a significant influence on the further development of various branches of agrarian science, were shown. Moreover, a significant role of the achievements of zemsky statisticians in solving actual scientific problems of the national agricultural science and practice of the designated period are shown, the contribution of the statistical methodology to the development of soil science, agronomy, agriculture and agricultural research are evaluated.

\section{REFERENCES}

1. Вергунов В. А. Історя грунтознавства в Україні: проблеми i методологія шляхів вирішення. Вісник Харківського національного грарного університету ім. В. В. Докучаєва. 2006. № 7. С. 20-37.

2. Дувин С. Гадячское районное опытное поле. Полтавские агрономические известия. 10 авг. 1913. Полтава: Типо-Литография И. Л. Фришберга, 1913. С. 16.

3. Елисеева И. И. История статистики. М. : Финансы и статистика, 1990. 296 с.

4. Журавский Д. П. Об источниках и употреблении статистических сведений. К. : Тип. И. Вильнера, 1846. 212 с. 
5. Ковальченко И. Д. Аграрный строй России второй половины XIX - начала XX в. / И. Д. Ковальченко ; Историко-филологическое отд. РАН. Комиссия по наследию акад. И. Д. Ковальченко. М. : РОССПЭН, 2004. 504 c.

6. Материалы для оценки земель Херсонской губернии. Т. 6. Херсонский уезд (статистико-экономическое описание уезда) / Сост. Стат. Отд. при Херсон. Губ. Зем. Управе. Херсон : Тип. О. Д. Ходушиной, 1890. XVIII, 458, 134 с.

7. Материалы для оценки земельных угодий, собранные Черниговским статистическим отделением при губернской земской управе. Том V. Козелецкий уезд. Чернигов: Губернская типогр., 1882. $75,101 \mathrm{c}$.

8. Материалы для оценки земельных угодий, собранные Черниговским статистическим отделением при губернской земской управе. Том VI. Конотопский уезд. Чернигов : Земская типогр., 1882. $62,93 \mathrm{c}$.

9. Материалы для оценки земельных угодий, собранные экспедиционным способом по программе бывшего Статистического Отделения при Черниговской Земской Управе. Новозыбковский уезд. Чернигов : Губернская типогр., 1880. 62, 79 с.

10. Материалы по исследованию почв и грунтов Подольской губернии. Том 1. Результаты полевых и лабораторных изысканий 1914 и 1915 г.г. / Под ред. Проф. Набоких А. И. Одесса : Типогр. Акционерного Южно-Русского Об-ва Печатного Дела, 1916. 268 с.

11. Сборник по хозяйственной статистике Полтавской губернии. Том X. Переяславский уезд. / под ред. Н. Кулябко-Корецького. Полтава : Типо-литогр. И. А. Дохмана, 1890. 286, 482 с.

12. Сельско-хозяйственный обзор Таврической губернии за десятилетие 1899-1908 г.г. Симферополь : Типогр. Таврического Губернского Земства, 1911. 167 с.

13. Сельско-хозяйственный обзор Черниговской губернии за 1913 г. Год 10-й. Чернигов : Типогр. Губернского Земства, 1915. 74,239 c.

14. Статистико-экономический обзор Херсонской губернии за 1898 год. Херсон : Паровая Типо-литогр. О. Д. Ходушиной, 1900. $300 \mathrm{c}$. 
15. Фортунатов А. Сельскохозяйственная статистика Европейской России. М. : Типо-Литогр. Тов. И. Н. Кушнеров и К., 1893. $250 \mathrm{c}$.

16. Червинский П. П. Земледельческая программа, приспособленная к собиранию сведений для оценки земледельческих угодий. Чернигов : Тип. губернского земства, 1881. Вып. 1-4. 26 с.

\section{Information about the author:} Vergunova I. M., Dr. habil, Professor, Professor at the Department of Mathematical Informatics, Taras Shevchenko National University of Kyiv 4d, Akademika Hlushkova Ave, Kyiv, 03680, Ukraine 


\section{STATE ARCHIVE OF LVIV OBLAST: SOURCE POTENTIAL FOR THE HISTORY OF UKRAINIAN CULTURE}

\section{Yanyshyn B. M.}

\section{INTRODUCTION}

Systemic and comprehensive research of the Ukrainian history of culture and science under the reign of Austria-Hungary started at the beginning of 1990, when the political changes in our country led to the removal of any restrictions on the usage of library and archive funds. Since that time the researchers started to actively investigate little-known materials in the richest collections of the Ukrainian central state historical archive in Lviv, Department of manuscripts in V. Stefanyk Lviv national library and State archive of Lviv oblast. This long-standing research of cultural and scientific Ukrainian materials in the abovementioned institutions resulted into the compilation of thematic indices that documented the state of processing of archive collections and at the same time they helped historians in their search for necessary documents. Nowadays, while we may turn to investigations on Ukrainian Central Historical Archive in Lviv ${ }^{1}$ (UCHAIL) and Manuscript Department of Ukrainian National Scientific Library in Lviv ${ }^{2}$ (MD UNSLIL), the on heuristic potential of State archive in Lviv oblast in the aspect of research on science and culture of Zbruch Ukrainians during national revival period remains virtually unknown.

Such state of affairs results from the range of objective and subjective reasons. First of all, the thematic profile of State Archive in Lviv oblast (SAILO), which was created in December 1939 on the basis of the former

\footnotetext{
${ }^{1}$ Громова Г. Джерела до вивчення львівського історичного середовища у фондах особового походження в Центральному державному історичному архіві України у Львові. Wielokulturowe środowisko historyczne Lwowa w XIX i XX w. Rzeszów: Wydawnictwo Uniwersytetu Rzeszowskiego, 2005. Tom III. St. 61-67; Łuczyńska B. Źródła do dziejów szkolnictwa w Galicji w zasobach Centralnego Państwowego Archiwum Historycznego we Lwowie - w perspektywie krystalizowania się narodu ukraińskiego. Prace Naukowe Akademii im. Jana Dlugosza w Częstochowie. Rocznik Polsko-Ukraiński. 2014. T. XVI. St. 281-297.

2 Дзьобан О. Михайло Грушевський в писемних джерелах Відділу рукописів ЛНБ ім. В.Стефаника НАН України. Збірник пращь $і$ матеріалів на пошану Лариси Іванівни Крушельницької. Львів,1998. Ст. 145-152.
} 
Polish state archive in Lviv, provides for preservation of materials of the modern period mostly. Besides, this archive is one of the few institutions of such fund variety that still does not have the guidebook on its own collections. The existing one dates back to $1965^{3}$ when the materials of the majority of Ukrainian cultural and scientific institutions were specially guarded as ones that were compiled by "nationalists". Obviously, that was a great complication in researching of SAILO materials, as even the most general idea can be envisaged only while directly dealing with them. That is why, only few collections that concern Ukrainian culture and science during Galician autonomy period became the subject of special, but most often superficial research. Let us recall the articles, devoted to arranging of Ivan Kalynovych ${ }^{4}$ private fund materials, the description of new submissions on literature and art figures during few years ${ }^{5}$, review of Hrushevsky studies in SAILO ${ }^{6}$ and its Country studies collections ${ }^{7}$.

Among the most remarkable projects we would like to mention Oksana Yurkova's big-scale project "E-archive of Mykhailo Hrushevsky" among the ambitious tasks of which there is document-by-document description of archive Hrushevsky materials in collections of Lviv oblast archive in particular. Recently, Vitaliy Telvak, responsible for his part in this project, uploaded annotations of more than 500 SAILO documents to the site of "E-archive of Mykhailo Hrushevsky". However, as the Drohobych historian himself mentioned, a complete description of Hrushevsky's materials in SAILO is still a matter of future. In order to draw attention of our colleagues to such a gap in investigation of these materials, in comparison to other archive institutions of such a level, we offer the overview of its collections, ones that contain materials on cultural and scientific life of Austrian Ukrainians during the second half of XIX beginning of XX century.

3 Львівський обласний державний архів: Путівник / Уклад.: В. І. Котельникова, Р. Б. Плоткіна, О. М. Рузанов; Під ред.: Б. К. Дудикевича та ін. Львів: Каменяр, 1965. 375 ст.; Державний архів Львівської області: Допов. до путівника / Упоряд.: В. М. Кислий, Л. М. Мінаєва, Р. Б. Плоткіна та ін.; Відп ред. Л. М. Мінаєва. К., 1988. 142 ст.

4 Калинець І. М., Кущ О. П. Упорядкування документальних матеріалів особистого фонду І. Т. Калиновича. Архіви Украӥни. 1971. № 1. Ст. 52-58.

5 Вайнбаум О. Т. Нові архівні знахідки про діячів літератури і мистецтва у Львівському облдержархіві. Архіви Украӥни. 1978. № 4. Ст. 72-73.

6 Савчук В. Документи Держархіву Львівської області про Михайла Грушевського. Михайло Грушевський: Погляд із сьогодення: Наук. зап. Тернопільського держ. пед. ін.-ту. Сер. «Історія». Тернопіль, 1997. Вип. 5. Ст. 222-223.

${ }^{7}$ Кравчук П. Фонди Держархіву Львівської області як джерело краєзнавчих досліджень. Студіі з архівної справи та документознавства. 2003. Т. 10. С. 152-153. 


\section{Lviv University Archive}

Collections of Lviv University fund contain the biggest amount of materials about Ukrainian culture and science of the autonomist period (f. 26 "Franz I Lviv Royal University"). This is one of the biggest funds of SAILO, it consists of 18 descriptions, regardless the fact that description 17 is followed by description number 22. It is supplemented by a brief information note about the history of this educational institution. This fund covers materials on the history of University until the beginning of the Second World War.

For the period that interests us the most, the most informative descriptions are among materials (administrative and business affairs) of juridical (description 6), philosophical (description 7), theological (description 8) and medical (description 10) faculties. Summary records of faculty meetings are especially important in source aspect. These records give us the possibility to observe the discussion of numerous questions concerning the education of Ukrainian students and teaching of Ukrainian professors and associate professors. Even most superficial overview of these sources allows to notice a visible tendency - more and more active efforts of Polish professor corporation to limit Ukrainian influence in the University. Even though the University was established as a bilingual institution, targeted at fulfilment of educational needs of local, predominantly Ukrainian population of Eastern Galicia, Polish majority at faculty and senate meetings established its domination in it. For example, Ukrainian students were forbidden to matriculate in Ukrainian language and their professors could not use Ukrainian language to resolve professional issues; besides, Ukrainian departments were deliberately reduced; Polish candidatures were appointed in all ways at open positions. As it is well-known, such conditions triggered a longstanding international conflict in Lviv University that exploded anew at the beginning of XX century, in particular, with armed conflict ${ }^{8}$. The most tragic consequence of this confrontation was the murder of Adam Kotzyk, a Ukrainian, by his Polish fellow students during one of the fights on the 1 of July 1910.

\footnotetext{
${ }^{8}$ Качмар В. За український університет у Львові. Ідея національної вищої школи у суспільнополітичному житті галицьких українців (кінець XIX - початок XX ст.). Львів: ЛДУ імені Франка; Інститут українознавства ім. І. Крип'якевича НАН України, 1999. 118 ст.; Ковалюк Р. Український студентський рух на західних землях. XIX-XX ст. Львів: Інститут українознавства ім. I. Крип'якевича НАН України, 2001. 420 ст.
} 
These descriptions contain reports on the work of faculty seminars, as well as protocols of faculty committees' meetings - regular ones (habilitational and librarian) and ones created for resolving numerous ongoing affairs: from versatile student issues to technical issues of University functioning. Let us draw attention to valuable for Ukrainian science researchers reports about the work of Oleksandr Kolessa's ${ }^{9}$ Ukrainian language seminar. Besides, among the meetings' reports of philosophical faculty there are protocols of habilitational colloquium of Ivan Franko ${ }^{10}$, Stepan Rudnytskyi ${ }^{11}$ and Stepan Tomashivskyi ${ }^{12}$.

The abovementioned descriptions of faculty affairs contain semesterby-semester programs of lectures and related correspondence of professors, Ukrainian ones in particular. The interesting fact is that some Ukrainian professors refused to give up on legally established bilingual character of the University. That is why their correspondence concerning different subjects to teach and suggestions on weekly distribution of classes was both in Ukrainian and state (German) language. Mykhailo Hrushevsky, as the most determined opponent of polonization course of Lviv University administration, acted in that way ${ }^{13}$.

The content of many documents of abovementioned faculty descriptions is connected with materials in descriptions 12-14 ("Rectorate"). Thus, the abovementioned tendency of limiting the rights of Ukrainian students is explicitly proved by cases of $13^{\text {th }}$ description. For example, the first case of this description contains reports of rector Ridiger to the Ministry of religion and education about the protests of Ukrainian students, correspondence with Galician Lieutenancy about national requirements of Ukrainian students, request of senate and the response of professor Hrushevsky and his participation in Ukrainian students' meetings and other interesting materials on these questions ${ }^{14}$.

The description 13 contains protocols of Lviv University meetings' protocols during the period under research. These documents provide us with information on numerous initiatives of Polish professors and

\footnotetext{
${ }^{9}$ Державний архів Львівської області. Ф. 26. Оп. 7. Спр. 446.

${ }_{10}$ Державний архів Львівської області. Ф. 26. Оп. 7. Спр. 362. Арк. 55-56.

11 Державний архів Львівської області. Ф. 26. Оп. 15. Спр. 726. Арк. 8-10.

12 Державний архів Львівської області. Ф. 26. Оп. 7. Спр. 623. Арк. 6, 19.

13 Державний архів Львівської області. Ф. 26. Оп. 7. Спр. 365. Арк. 6-7, 34, 90, 91, 98. Див. про це докл.: Тельвак В. Михайло Грушевський та польсько-український конфлікт у Львівському університеті: спроба реконструкції. Східноєвропейський історичний вісник. 2017. Вип. 4. Ст. 28-35.

${ }^{14}$ Державний архів Львівської області. Ф. 26. Оп. 13. Спр. 1. 33 арк.
} 
University administration directed on all-round limitation of Ukrainians' rights in it ${ }^{15}$. An interesting phenomenon is reflected in the range of cases with eloquent titles, let us take, for example, case 343 ("Protocols of secret meetings of the Polish Senate members in 1909 on the application of various methods for possible elimination of the already limited rights of Ukrainians in Lviv University, the appointment suspension of Ukrainian associate professors and professors and the abolition of the establishment of Ukrainian chairs; correspondence with Polish professors and deputies and the memorial to the Senate of the Minister of Galicia on this issue").

The urgency of University issue is evidenced by the case 46 ("The case of discussion of the project of formation [in indefinite future] of the Ukrainian university in Lviv"). The case 47 with memorials, notes and statements of Polish students and professors against the foundation of Ukrainian university in Lviv is also worth mentioning. Other cases of this description support the topicality of the issue ${ }^{16}$.

The cases of $13^{\text {th }}$ description provide information about Ukrainian secession 1901-1902 when Ukrainian students protested against the polonization of Lviv University and terminated their studies in the University in favour of other educational institutions of the empire. For example, let us recall cases 49 ("The case of the return of fees paid by Ukrainian students after their leaving of the University of Lviv in protest against the anti-Ukrainian behaviour of Polish university authorities in Lviv") and 50 ("The list of Ukrainian students from theological faculty that left the university in December 1901 in protest against the anti-Ukrainian educational policy of the Austro-Polish university authorities and the representative of the Austrian Ministry of Religious Studies and Education prof. Tsvyklinsky and secret notes about the organizers of this protest"). In addition, professors that supported the right of students for the use of Ukrainian language in the University faced disciplinary measures, which is registered in the $13^{\text {th }}$ description ${ }^{17}$.

The $13^{\text {th }}$ description also deposits chronicle materials of Lviv University covering 15 years span (1895-1910). Among these materials we find manually written autobiographies and lists of works for the corresponding period by professors and associate professors (among them

\footnotetext{
15 Державний архів Львівської області. Ф. 26. Оп. 13. Спр. 52, 53, 81.

16 Державний архів Львівської області. Ф. 26. Оп. 13. Спр. 344, 345.

17 Державний архів Львівської області. Ф. 26. Оп. 13. Спр. 409, 747, 748, 841, 842.
} 
there were Ukrainians too) for the chronicles ${ }^{18}$. The value of these materials is in the fact that the printed version of the chronicles of Lviv University included fragments of these manually written reports only.

Similar materials can be found in description 12 ("Rectorate"). It includes numerous cases with programmes of lectures and timeline for starting and finishing classes (cases 956, 1022, 1090, 1054). The correspondence with Lieutenancy in Lviv about the foundation of new departments, in particular those for Ukrainian candidates is also interesting. For example, let us recall the case about founding of the department of Old Church Slavonic language ${ }^{19}$. The cases that contain working materials for University chronicles are especially informative (cases 1088, 1089). Among the most important cases these are ones with lists of teaching staff (cases 958, 1091), biographies of professors and lists of their scientific works (case 931) and other similar materials. This description contains the cases that highlight the organization of student life in University - let us mention, for example, a case that has messages of student communities about elections of the board, hosting of numerous cultural events and correspondence with Lieutenancy in Lviv about the implementation of statute ${ }^{20}$.

Description 14 also contains documents related to rectorate. Among the most interesting and informative for our topic cases there are birth certificates of students (cases 2442, 2445, 2446, 2447); certificates about the secondary education of students (case 2443); index cards of students that graduated (case 2449); lists of students (case 2450). Case 2315 has biographies of professors, including Ukrainians.

Students' life of Ukrainian youth is described in $15^{\text {th }}$ case ("Catalogues of academic performance of students"). This description contains a great number of absolutoriums (certificates) of students about graduating from university. These cases give us information about lectures, and seminars that were attended the most frequently and what the academic performance was. The absolutoriums indicate such important information as names of secondary or high school institutions that students finished before entering the Lviv University and where they came from.

The absolutorium information is supplemented by similar by content documents from description 15 - the main student catalogues. These

\footnotetext{
18 Державний архів Львівської області. Ф. 26. Оп. 13. Спр. 6, 54, 116.

19 Державний архів Львівської області. Ф. 26. Оп. 12. Спр. 1054.

20 Державний архів Львівської області. Ф. 26. Оп. 12. Спр. 1099.
} 
materials provide information about the courses passed each semester with weekly hours of studies mentioned. Let us note that these sources are extremely informative, but not thoroughly enough studied. For example, they provide us with a unique opportunity to reconstruct what the class of Ukrainian professors was and to reveal which professors were the most popular among Ukrainian students. It is a tedious work, though, since one document can contain 1000 printing sheets.

The 15th description also provides us with such a valuable source as protocols on passing doctorate exams and conclusions about doctoral theses. These documents tell us about those few Ukrainian students that despite the unfavourable conditions managed to obtain doctoral degrees. For example, there are documents that confirm the obtaining of doctoral degree by $\mathrm{S}$. Tomashivskyi ${ }^{21}$, O. Terletskyi ${ }^{22}$, O. Sushko ${ }^{23}$, I. Krypiakevych $^{24}$, I. Dzhydzhora ${ }^{25}$, F. Sribnyi ${ }^{26}$, V. Herasymchuk ${ }^{27}$, I. Krevetskyi ${ }^{28}$, I. Shpytkovkyi ${ }^{29}$, S. Rudnytskyi ${ }^{30}$ and others. Some of these materials are already published ${ }^{31}$. Other valuable cases of this description are the book of registration of seminar works and doctoral theses that list surnames of students and their advisors, as well as topics of scientific works ${ }^{32}$. Doctoral diplomas register is also extremely important ${ }^{33}$.

Important materials on versatile activity of Ukrainian professors in Lviv University is highlighted in the description 5. It contains personal cases of such prominent representatives of Ukrainian culture and science of that time as S. Dnistryanskyi (case 584), I Sharanevych (case 1648), M. Hrushevsky (case 510), O. Ohinivskyi (case 1395), S. Rudnytskyi (case 1648), S. Tomashivskyi (1889), O. Kolessa (case 899), K. Studynskyi (case 1833) etc. These cases contain autobiographies, lists of scientific works, professional correspondence, characteristics, scientific materials etc. Needles to say about the informational value of these sources.

\footnotetext{
${ }^{21}$ Державний архів Львівської області. Ф. 26. Оп. 15. Спр. 726, арк. 66; 129.

22 Там само. Арк. 58.

${ }^{23}$ Там само. Арк. 106, 115, 130

24 Державний архів Львівської області. Ф. 26. Оп. 15. Спр. 727. Арк. 108-108.

${ }^{25}$ Там само. Арк. 156-156, 187.

${ }^{26}$ Там само. Арк. 188-188, 362.

27 Там само. Арк. 197-197, 364.

${ }^{28}$ Там само. Арк. 267-267.

${ }^{29}$ Там само. Арк. 333

30 Державний архів Львівської області. Ф. 26. Оп. 15. Спр. 726. Арк. 8-10.

31 Тельвак В., Педич В. Львівська історична школа Михайла Грушевського. Львів: Світ, 2016.

${ }^{32}$ Державний архів Львівської області. Ф. 26. Оп. 15. Спр. 1336.

33 Державний архів Львівської області. Ф. 26. Оп. 15. Спр. 1344.
} Ст. 380-391. 
Creative materials are gathered in the description 11 ("Master theses and articles"). The works of Ukrainian students, qualification cases and first drafts are of special importance to us. For example, let us draw attention to little-known manuscript drafts of S. Tomeshivkyi's works ("Citizens of Lviv and Khmelnytskyi rebellion in 1648 "34, a review to the work of M. Chechulin ${ }^{35}$ ), M. Korduba's ("The attitude of Bel III to Byzantine and the Third Crusade") $)^{36}$ and several essays of O. Terletskyi ${ }^{37}$.

\section{Funds of Higher Educational Institutions, Communities and Personalia}

Apart from documentation of Lviv University, collections of SAILO gathered collections of other prominent educational institutions in Lviv. Among them there are archives of Lviv Polytechnic (f. 27), Academy of veterinary medicine (f.46), Higher real school (f. 87) etc. However, regarding the technical-naturalistic and household-economic profile of these institutions as well as total domination among the teaching staff of Polish intellectuals, the Ukrainian voice and national issues did not have such a resonance as in Lviv University.

One of the important consequences of the obtaining of autonomy rights in Galicia was the dynamic creation and development of different structures of Galician society. The development of culture and science led to the foundation of versatile associations. SAILO preserved funds concerning these little-known Ukrainian institutions. In most of the cases, these funds contain limited number of files.

Fund number 280 contains documents on the activity of Ukrainian student Society "Rus academic help" in Lviv. The abovementioned lack of knowledge resulted in the case when the modern Lviv author that wrote on the history of this organization did not mention the whole fund in the list of archive sources used! ${ }^{38}$ Thus, in order to draw the colleagues' attention to the peculiarities of the collection, we would like to mention the statements on borrowings from funds of the Society (case 1), obligations on timely return of interest-free loans (case 2-7), Cash journal of the Society (case 8), lists of debtors (case 9), Statute of Lviv section of the Society "Ukrainian

\footnotetext{
${ }^{34}$ Державний архів Львівської області. Ф. 26. Оп. 11. Спр. 1880.

35 Державний архів Львівської області. Ф. 26. Оп. 11. Спр. 1881.

36 Державний архів Львівської області. Ф. 26. Оп. 11. Спр. 1652.

37 Державний архів Львівської області. Ф. 26. Оп. 11. Спр. 1867.

38 Сварник I. «Академічна поміч». Наук. т-во ім. Шевченка. Енциклопедія / Том I, А-Бібл / Уклад. НТШ. Львів, 2012. Ст. 102-103.
} 
student union" (case 10), financial reports (case 12), book of society's protocols (cases 14,15), materials of students' surveying (case 16), society leader's appeal to Ukrainian community with request for financial support (case 19) etc.

Materials of the Society "Sich" for 1901-1913 are kept in the fund 290. It consists of eight storage units, that contain correspondence of student "Sich" affiliations in Vienna, Nediev, Chernivtsi with Lviv society about different issues of cooperation (case 1), the book of protocols on presidium meetings during 1902-1908 (case 2), check book of membership fees by society members (case 3), materials on spreading the tickets for different charity events (case 4), program and campaign documents (case 5), drafts of announcements, notes, reviews, recommendations for the society (cases 6-7).

Little-known are also materials of the board of Society "Committee of Academic house" in Lviv; they are preserved in the fund $292^{39}$. This fund contains 33 cases, that allow us to comprehensively reconstruct its activity. Among the files there are documents (contracts, bills, cadastral maps, etc) on obtaining the land for building the Academic house (case 1), cash book of Academic house (case 2), statements about taxes on SSS houses and notices for Lviv magistrate about terms of tax payments (case 3), appeal of SSS on collecting voluntary charity contributions among Ukrainians on both banks of Zbruch for construction (case 5), cost estimates of juridical assistance of some cases (case 6), numerous financial materials concerning the construction and functioning of Academic house (cases 7, 8, 13, 14, 18, 20, 21, 23, 25-32), inventory description (case 9), statute (case 11), lists of tenants from different years (case 12), announcements of "Academic house committee" (case 17) etc. We would like to draw attention to unnoticed before case 4, that contains the correspondence of the head of SSS M. Hrushevsky with lawyers that gave advice on the construction of Academic house. Cases 15 and 16 also contain the book of meetings of "Academic house committee".

39 Див.: Брилинський Т. Б. „Академічний дім“ у Львові - сторінка історії НТШ. Т. Шевченко $i$ украӥнська національна культура. Львів, 1990. Ст. 141-142; Вуйцик В. 3 історії будинків Наукового товариства ім. Шевченка у Львові. 3. Будинок на вул. Коцюбинського, 21 (Супінського, 17). 3 icmopiï Наукового товариства імені Шевченка. Львів, 1997. Ст. 258-259; Головацький І. Український Академічний дім НТШ у Львові і національно-визвольний рух. Вісник НТШ. 2000. Ч. 23. Ст. 32-33; Старовойтенко І. Євген Чикаленко і Наукове товариство ім. Шевченка. Вісник НТШ. 2011. Ч. 46. Ст. 31-36; Панькова С. М. Академічний Дім у Львові: спільний проект Михайла Грушевського та Свгена Чикаленкаю Свген Чикаленко - будитель украӥнської начії (До 150-річчя від дня народження). Збірник наукових пращь. К., 2014. Ст. 95-113. 
The biggest number of materials is preserved in the fund 203 "Society of Ukrainian students of Polytechnic "Osnova" in Lviv" that has 103 storage unit. Among them, let us draw the attention of researchers to the cases that contain the statutes and regulations (cases 6-8, 30, 40), minutes of general and regular meetings (cases 2, 14, 15, 19), statistics and reports (cases $10,20,74,79$ ), the lists of members of the Society (cases 1, 41, 42, $56,85,90,93$ ), statements of the members of the Society (cases 4, 31, 32, 43, 44, 80, 99), correspondence with student associations about holding general meetings, celebrations, workshops, etc. (cases 16, 22, 23, 34, 35, 57-59), accounting books for contributions (cases 24, 25, 51), inventory books of the library, lists of books, books of the accounting of library editions (cases 3, 38, 65) , 66), cash books and accounts (cases 11, 26, 27, $36,37,46-50)$, receipts for receiving cash grants, purchase of literature, payment of contributions (cases 5, 17, 71), etc.

Fund 295 is also rather informative as it contains versatile documents of the Society of Ukrainian craftsmen and entrepreneurs "Zorya" in Lviv. It consists of 77 cases that allow us to reconstruct all aspects of functioning of this important institution for the economic culture of Galician Ukrainians $^{40}$. The following documents deserve special attention as they are highly informative for researchers (cases 26, 36, 68, 70, 71), cash books and other financial documents (cases 1, 2, 19, 21, 23, 25, 32, 34, 59, 60 ), various materials (reports, lapels, correspondence, posters, etc.) about the activities of the Company and its numerous affiliates (cases 3, 11, 13, $16,17,18,20,22,24,27-29,33,37,38-58,62-64,66,67,73,74)$, membership books (cases 4, 4 a, 9, 10, 65, 69, 75-76), books of protocols (cases 6, 7, 12, 14, 15, 30, 31, 72) and others.

The fund 296 of the Society "Academic Community" that contains 96 storage units is also significant in terms of volume and diversity of deposited materials. As in the above-mentioned case, the fund "Rus Academic Aid" in Lviv also remains unknown to contemporary researchers of the Ukrainian institutional life of an autonomy period. In the corresponding entry of "Encyclopaedia of SSS" in the review of archival sources on the history of the institution, the existence of this fund in SAILO was also silenced ${ }^{41}$.

\footnotetext{
40 Пасіцька О. Львівська «Зоря» - товариство українських ремісників, промисловців і торговців (1884-1939): історичний нарис. Львів: Інститут українознавства ім. І. Крип’якевича НАН України, 2013. 88 ст.

${ }^{41}$ Сварник I. «Академічна громада» у Львові. Наук. т-во ім. Шевченка. Енциклопедія / Том I, А-Бібл / Уклад. НТШ. Львів, 2012. Ст. 100-102.
} 
By attracting the attention of researchers to its content diversity, among the most interesting storage units, we would like to notice those containing the statutes and liquidation acts (case 24), the books of protocols (cases $3,33,51,86$ ), the various correspondence ( cases 4-6, 26, $27,30-32,34,40,46,58,60,65,76,80,83$ ), financial documentation (cases 9, 11, 12, 14-16, 28, 35, 36, 41 , 44, 45, 47, 48, 54, 56, 62, 63, 66, $70,78,82$ ), the registration books of members (cases $7,8,10$ ), statements of members of the society on various issues (cases 17-23), creative materials of the members of the society (cases 88-91), etc.

The fund 297 contains the documentation of another Ukrainian student association "Academic Brotherhood" in Lviv. The fund has 41 storage unites. Among them, the most informative cases are diverse correspondence (cases 1, 4, 7, 8, 27, 30), library catalogues and reports (cases 2, 6, 11, 32, 38, 40), book of protocols ( cases 3, 16, 19, 21, 26, 37) and the organization's note books (cases 20,22,31,36), the book on registration of voluntary donations of private individuals for a company (case 5), financial documentation (case 9, 12, 15, 17, 23) and others.

The fund 298 preserves the materials of the created in February 1904 by M. Hrushevsky and his associates Ivan Trush, Ivan Franko and Volodymyr Hnatyuk Society of Supporters of Ukrainian Literature, Science and Crafts in Lviv. The fund has nine storage units. The most valuable file is the third case of the fund, which contains a protocol book of the general meetings of the members of the Society and meetings of its board, as well as financial accounts. It is worth mentioning that nowadays the mentioned protocols of the Society are published by the Lviv archaeologist Oleg Kupchinsky ${ }^{42}$. Excerpts from the minutes of the general meeting of the members of the society and the meetings of his board were highlighted in the fourth case. Drafts and originals of the Articles of Association are contained in the first and second cases. The correspondence of the Society members with representatives of his board, as well as numerous requests for financial support of the beginning artists are kept in the fifth case.

The sixth case contains the institutional correspondence ("Letters of Regional department, Kyiv literary-artistic society and editor of publishing house "Ruska pysmennist" (Rus litteracy) Yu. Romanchuk on sending the information about the society's activity, participation in commemoration of

\footnotetext{
${ }^{42}$ Купчинський О. Статут і протоколи засідань Товариства прихильників української літератури, науки і штуки у Львові. Записки НTШ. 1994. Том CCXXVII. Праці Секції мистецтвознавства. Ст. 393-419.
} 
35-year anniversary of the writer Ivan Nechui-Levytskyi and the preparation for publication of Marko Vovchok's works"). The two last cases of the fund ( 8 and 9) contain all the details on two biggest cultural events - Higher vacation summer courses and exhibition of Ukrainian modern $\operatorname{art}^{43}$.

Society "Medical community" was created to protect corporate rights of Ukrainian doctors and its documents were included in the fund № 299. It contains 67 cases. The most informative cases from the autonomous period include reporting documentation (cases 1, 7,8), protocol book of board and general meeting (case 2), lists of Society members (case 3), address alphabet book (case 4), library catalogues (cases 5,6), etc.

The majority of abovementioned Ukrainian societies had Lviv "registration". Thus, Ukrainian cultural and scientific life in Galician province in the documents of the institutions mentioned is represented, mostly, in fragments - only if a society had its own affiliations in Eastern Galician towns. Thus, numerous documents of SAILO that highlight provincial centres are of crucial importance. A lot of files of several Sambir institutions were preserved in that fund after liquidation of Drohobych oblast and transfer of its archives to Lviv.

Let us mention the fund 1245 of Sambir Society "Boikivshchyna" that keeps first and second description with 160 and 47 cases respectively. This fund keeps such interesting cases from Galician autonomy period as Country studies materials (description 1, case 25), appeals of Ukrainian peasantry to support Ukrainian youth in their aspirations for founding Ukrainian high school (description 1, case 27), manuscript of literary, scientific and memoir works of Society members (description 1, description 28, 31, 33-35; description 2, case 21), lists of members of cultural societies in Sambir (description 1, case 32), statutes, reports, appeals and correspondence of Ukrainian societies in Sambir (description 2, case 17; description 2, case 22, description 2, cases 23-27), etc.

Among Ukrainian societies with Sambir "registration" there are materials of the Society "Ukrainian conversation" that made up fund №1182. It contains 18 cases. These cases deposit documents that have lists of society members (case 1), various correspondence (case 2), meetings' protocols (case 3), etc.

\footnotetext{
${ }^{43}$ Yanyshyn B. Organization and activity of the Ukrainian Literature, Science and Crafts Society in Lviv. Східноєвропейський історичний вісник. 2018. Вип. 8. Ст. 18-27.
} 
The oldest and the most respected Galician "Prosvita" institute that was located in Sambir deposited informative archive materials as well (fund 1151). The fund contains 26 cases. The period under study is represented in important cases that provide information on functioning of different reading halls (cases 1-8, 11-13), various correspondence (case 9), business materials (case 10), meetings' protocols (case 14), instructive materials (cases 15,16), membership lists (case 17), reports on the activity of numerous communities (cases 18, 20), financial documentation (case 19) and other.

The period of Galician autonomy is also the period of tremendous thriving of periodicals, mostly Polish and Ukrainian social-political journals. Researchers unanimously recognize the fact that it was Galicia where the biggest number of different editions was published during that time of dependence of our nations. Editorial funds of several Ukrainian newspapers and journals were also deposited in SAILO. Thus, the fund 116 contained a small archive of the famous Lviv magazine "Citizen's voice". It contains the address book of newsletter subscribers.

A slightly more voluminous is fund 315 that deposited versatile documentation of the editorial board of Lviv magazine "Our voice" in Lviv. Creative drafts of the periodical writers dominate quantitatively among the materials of the fund. Let us name manuscripts of O. Skoropys' articles ("Social-democratic movement in Skvir and Vasylkiv areas in 1906"), O. Prylutskyi ("Getting on our own feet! ... (On the occasion of discorded congress)"), L. Yurkevych ("The tenth congress of Czech socialdemocratic party in Prague"), L. Vinter ("Austrian labour statute compilation"), P. Ponyatenko ("Culture, nationality and assimilation in their mutual relations"), V. Vinnychenko ("On the ethics of the rulers and ethics of the oppressed"), etc.

Among the range of personal funds in SAILO, only Ivan Kalynovych is distinguished as a fund compilator (f. 306). His fund is rather rich as it contains 246 storage units. This fund preserved such important materials as the letters of the fund compilator himself to his wife Eugenia Klynovych (case 1); letters to I. Kalynovych (case 2); materials to the biography of I. Kalynovych (case 3); creative materials of Kalynovych: autographs and article printings, researches, bibliographical reviews, notes, etc (cases 9, 12, 13, 16-22, 24-49); Kalynovych's collected materials: manuscripts (cases 23, 50, 51-83) and publications (M. Yatskov (case 14), M. Bohun 
(case 84), A. Hertsen (case 93), O. Hranovskyi (case 94), L. Martovych (case 104), Yo. Slipyi (case 119), etc) and other authors; different periodicals (cases 86-91, 95-97, 105-109, etc). The biggest part of the fund - bibliographical heritage of I. Kalynovych that contains big cases with manuscript pages distributed by thematic (e.g. "Prague commune" (case 176), "Socialist literature" (case 177), "Bibliography, Library studies and book studies" (case 178), etc) and personal (e.g. D. Dontsov (case 15), V. Lenin (case 175), V. Vynnychenko (case 211), T. Shevchenko (case 230)) criteria.

We would like to mention that epistolary Ukrainian materials of scientific character is also preserved in funds of Polish intellectuals that lived during the period under study. Obviously, the search for them is a tedious task, and a rewarding one, though. For example, in personal fund of Ludwig Finkel - professor of Ian Kazimierz University of Lviv there were found virtually unknown letters of M. Hrushevsky to his colleaguehistorian $^{44}$. We are strongly convinced that searches in personal funds of other intellectuals, preserved in SAILO may reveal other interesting documents.

\section{Lviv Police Fund}

A considerable number of sources that can help us study Ukrainian scientific and cultural source material is deposited in the fund of the police command in Lviv (f. 30) that has 30 descriptions of chronologically arranged materials. First of all, let us draw attention of researchers to such important group of documents as accounting tables for all Ukrainian periodicals that were published in Galicia during autonomy period. For example, cases 2468 (Accounting table for Ukrainian journal "Dzvinok" (A call)), 2469 (Accounting table for Ukrainian journal "Uchytel" ("A Teacher")), 2470 (Accounting table for Ukrainian weekly ("Ruske slovo") "Rus word"), 2509 (Accounting table for Ukrainian magazine "Galician citizen"), 2567 (Accounting table for Ukrainian journal "Literaturno-Naukovyi Visnyk" ("Literary-Scientific Herald")), 2568 (Accounting table for Ukrainian weekly "Svoboda" ("Freedom")), 2569 (Accounting table for Ukrainian magazine "Ruslan"), 2647 (Accounting table for Ukrainian biweekly "Komar"), 2648 (Accounting table for Ukrainian journal "Moloda Ukraina" ("Young Ukraine")).

${ }^{44}$ Державний архів Львівської області. Ф. 254. Оп. 1. Спр. 313. 11 арк. 
A lot of cases were opened because of the confiscation of certain issues of Ukrainian magazines and journals, that failed censorship check. For example, the case 2348 reveals the correspondence with Galician Lieutenancy about the confiscation of the periodical "Druh" ("Friend") published by "Academic circle" for publication of the article "A call to all". In its turn, the case 2767 contains materials on confiscation of the "Dilo" issue for publication of the article "The Society "Rural master". The list of such cases is ongoing.

Besides, the materials of police fund contain documents linked with the case of registration of Ukrainian scientific and civic institutions. In the majority of cases, the permits were issued without any obstacles. However, the funds reveal several cases on motivation of refusing in permit's issue for Ukrainian society. For example, a case 2603 that contains correspondence with Galician Lieutenancy about permit refusal for the society "Rus glory". The case 2805 about shutting down Ukrainian society "Early star" in Lviv is also interesting.

The group of cases in the police fund that contains permits on holding different Ukrainian cultural events is similar to the above-mentioned one. Here we can note a range of cases with materials on censoring Ukrainian theatrical and artistic plays and other art events. A case 2226, for example, reveals correspondence with Galician Lieutenancy on refusal for the staging the play "Pan Dovhonis" ("Mister Longnose") in Ukrainian theatre.

The abovementioned police fund is extremely important for understanding of persecutions and oppression that Ukrainian cultural and scientific activists suffered for their civil and political work. For example, the case 2525 contains interesting materials on deportation of Russian journalist Vasyl Vodoviz for alleged correspondence with Lesya Ukrainka, Mykhailo Pavlyk, Teophil Okunevskyi and other Ukrainian activists. Materials of 2549 storage unit contain documents of the Yosyp Shpytko case, an employee of magazine "Dilo", who was already convicted for agitation during the peasants' strike.

Case 2707 reveals materials on confiscation of the issue of Semen Vityk "What to do next? A response to the case of the great peasant's strike". The case 3903 contains versatile documents on criminal charges pushed against Mykhailo Hrushevsky for publicist speeches in Russian press that allegedly urged to annex inhabited by Ukrainians Eastern Galicia to Russian Empire. Similar documents are stored about such activists of 
different political orientations as Olersandr Barvinskyi ${ }^{45}$, Ivan Franko ${ }^{46}$, Mykhailo Pavlyk $^{47}$, Ivan Naumovych ${ }^{48}$, Kyrylo Studynskyi ${ }^{49}$ and others, which also encourages us to pay closer attention to the heuristic potential of the fund 350 .

\section{CONCLUSIONS}

Needless to say, that the abovementioned observation of Ukrainian cultural and scientific peculiarities in the funds of SAILO is far from being thorough because of the limitations of the article's format. However, the depicted versatility and richness of the documents revealed are to urge researchers to comprehend the enormous, yet underestimated, heuristic potential of the State archive in Lviv oblast and to more actively investigate its collections. The conclusions of this work should result in problem-thematic analytical research, collective compilation of the catalogue guide through Ukrainian cultural-intellectual materials deposited in plenty in SAILO funds.

\section{SUMMARY}

The article investigates the informational potential of State Archive in Lviv oblast collections in order to enrich knowledge about the Ukrainian culture and science of Hapsburgs empire during autonomous period. It has been proved that the richest in documents was the fund of Lviv University. We also have revealed that SAILO preserved collections of Ukrainian cultural-educational institutions ("Rus academic help", "Sich", "Committee of Academic house", "Society of Ukrainian students of Polytechnic "Osnova" in Lviv", "Academic society", "Zorya", "Academic brotherhood", "Society of Supporters of Ukrainian Literature, Science and Crafts in Lviv", "Medical community", "Boikivshchyna", periodicals (e.g. "Civil voice" ("Hromadskyi holos") and "Our voice" ("Nash holos")) and activists (I. Kalynovych). It has been noted that the majority of sources for study of the Ukrainian cultural and scientific source materials are deposited in the fund of Lviv police command. The conclusion states about the versatility and richness of documents and materials and it encourages

\footnotetext{
${ }^{45}$ Державний архів Львівської області. Ф. 350. Оп. 1. Спр. 2806. 4 арк.

46 Державний архів Львівської області. Ф. 350. Оп. 1. Спр. 2356. 27 арк.

47 Державний архів Львівської області. Ф. 350. Оп. 1. Спр. 2325. 126 арк.

48 Державний архів Львівської області. Ф. 350. Оп. 1. Спр. 2336. 162 арк.

49 Державний архів Львівської області. Ф. 350. Оп. 1. Спр. 2941. 21 арк.
} 
the researchers to comprehensively investigate the heuristic potential of the Lviv oblast archive and to compose collective compilation of the catalogue guide through Ukrainian cultural-intellectual materials.

\section{REFERENCES}

1. Брилинський Т. Б. «Академічний дім» у Львові - сторінка історії НТШ. Т. Шевченко і українська наџіональна культура. Львів, 1990. Ст. 141-142.

2. Вайнбаум О. Т. Нові архівні знахідки про діячів літератури і мистецтва у Львівському облдержархіві. Архіви Украӥни. 1978. № 4. Ст. 72-73.

3. Вуйцик В. 3 історії будинків Наукового товариства ім. Шевченка у Львові. 3. Будинок на вул. Коцюбинського, 21 (Супінського, 17). 3 історї Наукового товариства імені Шевченка. Львів, 1997. Ст. 258-259.

4. Головацький I. Український Академічний дім НТШ у Львові і національно-визвольний рух. Вісник НТШ. 2000. Ч. 23. Ст. 32-33.

5. Громова Г. Джерела до вивчення львівського історичного середовища у фондах особового походження в Центральному державному історичному архіві України у Львові. Wielokulturowe środowisko historyczne Lwowa w XIX $i$ XX w. Rzeszów: Wydawnictwo Uniwersytetu Rzeszowskiego, 2005. Tom III. St. 61-67.

6. Державний архів Львівської області. Ф. 254. Оп. 1. Спр. 313.

7. Державний архів Львівської області. Ф. 26. Оп. 11. Спр. 1652.

8. Державний архів Львівської області. Ф. 26. Оп. 11. Спр. 1867.

9. Державний архів Львівської області. Ф. 26. Оп. 11. Спр. 1880.

10. Державний архів Львівської області. Ф. 26. Оп. 11. Спр. 1881.

11. Державний архів Львівської області. Ф. 26. Оп. 12. Спр. 1054.

12. Державний архів Львівської області. Ф. 26. Оп. 12. Спр. 1099.

13. Державний архів Львівської області. Ф. 26. Оп. 13. Спр. 1.

14. Державний архів Львівської області. Ф. 26. Оп. 13. Спр. 116.

15. Державний архів Львівської області. Ф. 26. Оп. 13. Спр. 344.

16. Державний архів Львівської області. Ф. 26. Оп. 13. Спр. 345.

17. Державний архів Львівської області. Ф. 26. Оп. 13. Спр. 409.

18. Державний архів Львівської області. Ф. 26. Оп. 13. Спр. 52.

19. Державний архів Львівської області. Ф. 26. Оп. 13. Спр. 53.

20. Державний архів Львівської області. Ф. 26. Оп. 13. Спр. 54. 
21. Державний архів Львівської області. Ф. 26. Оп. 13. Спр. 6. 22. Державний архів Львівської області. Ф. 26. Оп. 13. Спр. 747. 23. Державний архів Львівської області. Ф. 26. Оп. 13. Спр. 748. 24. Державний архів Львівської області. Ф. 26. Оп. 13. Спр. 81. 25. Державний архів Львівської області. Ф. 26. Оп. 13. Спр. 841. 26. Державний архів Львівської області. Ф. 26. Оп. 13. Спр. 842. 27. Державний архів Львівської області. Ф. 26. Оп. 15. Спр. 1336. 28. Державний архів Львівської області. Ф. 26. Оп. 15. Спр. 1344. 29. Державний архів Львівської області. Ф. 26. Оп. 15. Спр. 726. 30. Державний архів Львівської області. Ф. 26. Оп. 15. Спр. 727. 31. Державний архів Львівської області. Ф. 26. Оп. 7. Спр. 362. 32. Державний архів Львівської області. Ф. 26. Оп. 7. Спр. 365. 33. Державний архів Львівської області. Ф. 26. Оп. 7. Спр. 446. 34. Державний архів Львівської області. Ф. 26. Оп. 7. Спр. 623. 35. Державний архів Львівської області. Ф. 350. Оп. 1. Спр. 2325. 36. Державний архів Львівської області. Ф. 350. Оп. 1. Спр. 2336. 37. Державний архів Львівської області. Ф. 350. Оп. 1. Спр. 2356. 38. Державний архів Львівської області. Ф. 350. Оп. 1. Спр. 2806. 39. Державний архів Львівської області. Ф. 350. Оп. 1. Спр. 2941. 40. Державний архів Львівської області: Допов. до путівника / Упоряд.: В. М. Кислий, Л. М. Мінаєва, Р. Б. Плоткіна та ін.; Відп ред. Л. М. Мінаєва. К., 1988. 142 ст.

41. Дзьобан О. Михайло Грушевський в писемних джерелах Відділу рукописів ЛНБ ім. В.Стефаника НАН України. Збірник праць i матеріалів на пошану Лариси Іванівни Крушельницької. Львів, 1998. Ст. 145-152.

42. Калинець I. М., Кущ О. П. Упорядкування документальних матеріалів особистого фонду I. Т. Калиновича. Архіви Украӥни. 1971. № 1. Ст. 52-58.

43. Качмар В. За український університет у Львові. Ідея національної вищої школи у суспільно-політичному житті галицьких українців (кінець XIX - початок XX ст.). Львів: ЛДУ імені Франка; Інститут українознавства ім. І. Крип'якевича НАН України, 1999. $118 \mathrm{c}$.

44. Ковалюк Р. Украӥнський студентський рух на західних землях. $X I X-X X \mathrm{~cm}$. Львів: Інститут українознавства ім. І. Крип'якевича НАН України, 2001. 420 ст. 
45. Кравчук П. Фонди Держархіву Львівської області як джерело краєзнавчих досліджень. Студіі 3 архівної справи та документознавства. 2003. Т. 10. С. 152-153.

46. Купчинський О. Статут i протоколи засідань Товариства прихильників української літератури, науки і штуки у Львові. Записки НTШ. 1994. Том CCXXVII. Праці Секції мистецтвознавства. Ст. 393-419.

47. Львівський обласний державний архів: Путівник / Уклад.: В. І. Котельникова, Р. Б. Плоткіна, О. М. Рузанов; Під ред.: Б. К. Дудикевича та ін. Львів: Каменяр, 1965. 375 ст.

48. Панькова С. М. Академічний Дім у Львові: спільний проект Михайла Грушевського та Євгена Чикаленкаю Євген Чикаленко будитель украӥнської начї (До 150-річчя від дня народження). Збірник наукових праць. К., 2014. Ст. 95-113.

49. Пасіцька О. Львівська «Зоря» - товариство українських ремісників, промисловців і торговців (1884-1939): історичний нарис. Львів: Інститут українознавства ім. І. Крип'якевича НАН України, 2013. 88 ст.

50. Савчук В. Документи Держархіву Львівської області про Михайла Грушевського. Михайло Грушевський: Погляд із сьогодення: Наук. зап. Тернопільського держ. пед. ін.-ту. Сер. «Ітторія». Тернопіль, 1997. Вип. 5. Ст. 222-223.

51. Сварник I. «Академічна громада» у Львові. Наук. т-во ім. Шевченка. Енциклопедія / Том I, А-Бібл / Уклад. НТШ. Львів, 2012. Ст. 100-102.

52. Сварник I. «Академічна поміч». Наук. т-во ім. Шевченка. Енциклопедія / Том I, А-Бібл / Уклад. НТШ. Львів, 2012. Ст. 102-103.

53. Старовойтенко I. Свген Чикаленко і Наукове товариство ім. Шевченка. Вісник НТШ. 2011. Ч. 46. Ст. 31-36.

54. Тельвак В. Михайло Грушевський та польсько-український конфлікт у Львівському університеті: спроба реконструкції. Східноєвропейський історичний вісник. 2017. Вип. 4. Ст. 28-35.

55. Тельвак В., Педич В. Львівська історична школа Михайла Грушевського. Львів: Світ, 2016. 424 ст.

56. Łuczyńska B. Źródła do dziejów szkolnictwa w Galicji w zasobach Centralnego Państwowego Archiwum Historycznego we Lwowie - w perspektywie krystalizowania się narodu ukraińskiego. Prace 
Naukowe Akademii im. Jana Dlugosza w Częstochowie. Rocznik PolskoUkraiński. 2014. T. XVI. St. 281-297.

57. Yanyshyn B. Organization and activity of the Ukrainian Literature, Science and Crafts Society in Lviv. Східноєвропейський історичний вісник. 2018. Вип. 8. Ст. 18-27.

\section{Information about the author: \\ Yanyshyn B. M.,}

Candidate of Historical Sciences,

Senior Research Fellow

at the Department of History of Ukraine XIX - early XX century, Institute of History of Ukraine of the NAS of Ukraine 4, M. Hrushevsky St., Kyiv, 02000, Ukraine 


\section{POLITICIZATION OF HISTORY: TERMS, METHODS, SIGNIFICANCE}

\section{Yaremchuk V.P.}

\section{INTRODUCTION}

The current state of the world historical thought is remarkable for an unusual coexistence of the high professional standards with a still significant influence on the history writing of the political force field in its different facets and manifestations, which prevents historians from achieving their "noble dream" (as Piter Novik would say). Moreover, the presence of politics in modern historiography is seen not only in obvious things, e.g. its involvement in historical politics, discussed in the tiniest details, but also in reputable historical doctrines and directions which represent "pure science" ("critical", "research" etc), and which, according to the critics, hide (and sometimes directly declare) some pragmatic interests behind apparent scientism. Modernization theory, oriented towards the support of Western liberal democracy, academically reputable German Alltagsgeschichte and Italian Microstoria, designed to promote democratic values and carry out a specific liberation mission of historical research, let alone post-colonial studies and history of women and gender which some respectable scientists do not consider a science but rather an ideological product ${ }^{1}$, comprise a list of influential in the world historiography methods of learning the past, which are accused of being politically engaged. Among them, there is still dominant in the world historiography (in the sense of the number of scientists and amount of resources) national history, which, according to Stefan Berger, rose like a phoenix in some Western countries ${ }^{2}$.

\footnotetext{
1 Janowski M. Postmodernizm przed modernizmem. Historia - dziś. Teoretyczne problemy wiedzy o przeszłości. Kraków, 2014. S. 38.

${ }^{2}$ Berger S. Rising Like a Phoenix... The Renaissance of National History Writing in Germany and Britain since the 1980s. Nationalizing the Past: Historians as Nation Builders in Modern Europe. New York, 2010. P. 426-451. According to the German historian, even in the epoch of globalization the national narratives "continue to provide a relevant framework and importance for building identities" (Ibid., p. 451). Following such a respectable modern researcher of the history of historiography, by the term "national history" we understand a specific form of historical representation, which is aimed at forming national countries and accompanies the formation of national countries or strives to influence the existent self-determination of national $\mathrm{c}$ of national (Baár M. Historians and Nationalism. East-Central Europe in Nineteenth Century. New York, 2010. P. 2). For modern trends of national history writing, see: Иггерс Г., Ван Э. Глобальная история современной историографии. Москва, 2012. С. 411-420.
} 
Such problems as methods of political influence on the professional history writing, methods of adaptation to the political pressure and the feedback effect of historiography and historians on the political sphere are at the center of researchers' interests. For the last decades, special attention has been paid to the significant role of professional historiography in the process of shaping the politics of memory and politics of identity, particularly creating images of the national past. It is acknowledged that the intervention of politics in historiography has many dimensions and aspects, from mixed signals from authorities who are in the process of seeking an acceptable image of the past for themselves ("the ways of which are mysterious", according to the sarcastic remark of the Russian historian Pavlo Uvarov ${ }^{3}$ about the Soviet style of the historical science management) to the explicit directives and direct participation of "masters of possible" in the writing of historical texts as in cases with Joseph Stalin, Turgut Ozal or Saddam Hussein ${ }^{4}$. The historians' activity may also vary from voluntary and overwhelming support of ruling regimes, direct participation in writing political programmes and shaping practical politics (it is common knowledge that the historians were, for instance, among the architects in the majority of nations-countries, created in the 19th-the beginning of the 20th centuries in Europe) to the opposition activity, in which the historical publications are used as means of fight and resistance (such examples are of course rare).

Irrespective of the forms and manifestations of the interaction between politics and professional historiography, a direct contact point of these "spheres" is a historical text as a product of creative work of a professional historian and, at the same time, a result of such "cooperation". As a matter of fact, in this article, by the term "politicization of history" we understand politicization of texts, written by professional historians, and by "politicized history" - the politicized texts of the same professional historians of the past. With a small number of empirical studies on the respective subject, there are not enough reflections about the historical representations that should be considered "politicized history" in space and

\footnotetext{
${ }^{3}$ Свобода у историков пока есть. Во всяком случае - есть от чего бежать: беседа Кирилла Кобрина с Павлом Уваровым. URL: http:// magazines.russ.ru/nz/2007/55/sb5.htm (access date May 16, 2019).

${ }^{4}$ J. Stalin is famous as an actual co-author of a "too long" "Short Course History of the CPSU(B)" (1938). Several essays in a book under a distinctive title "On How to Write the History" (1979) belong to S. Hussein, and the head of the Turkish government and shortly after the President of Turkey wrote the "research" "Turkey in Europe" (1988), in which he was persuading readers that his country was a true motherland of European civilization.
} 
time. From our perspective, such a gap contributes to a rather blurry and sometimes unreasonable arbitrary understanding of this term regardless of the terms, which are used to signify it ("[politically] engaged history", [politically] tendentious history" etc.). The issue of the attitude towards the politicized history writing also demands special attention: does the usage of professional historiography to serve the politics only harm the historical knowledge and should we speak about more ambivalent implications? And one more problem that deserves a special contemplation is whether history writing can be free from politics and if yes, then under what circumstances; if not, then why? Doubtless, the above-mentioned thoughts do not claim to be in possession of the "absolute truth" - to think differently in conditions of a significant complexity of the problem would be at least a demonstration of intellectual disabilities or naive self-confidence.

\section{Politicized History: An Attempt to Define the Term}

In our opinion, the term "politicized history" has several meanings. It should be considered in the context of its dependence on both the subjective intentions of the historian and the socio-political situation of his works and perception of their result - the historical text. The most obvious meaning of this category is in the practice of writing the texts that justify the existing political order or, on the contrary, try to change it and substantiate the benefits of another, "better" and more desirable. In other words, the point of issue is the direct support of existing political regimes through historical representations or the nomination of their opponents for governmental positions. Such a direct intrusion of political order into the "scientific" research is a result of either coercive pressure of the government on the historians or voluntary service to the politicians' interests, or a combination of the first and second factors. The phenomenon of historiography, which is often called "court" due to its overt service to the interests of high profile officials, appeared in China at the end of the 2 century B.C., when the historians became public servants. It was successfully tested in the European monarchies of the Middle Ages and new times, justified in the works of the representatives of "Prussian" school of historiography, the historians of the Third Reich and the Soviet Union (let's recollect the notoriously famous "principle of party membership") and survived to this day. 
The other form of politicized history has a more complex nature. The historical representation may not only fuel by the historical arguments and legitimize the existing or alternative power but also drive changes of social, gender, religious and ethno-national order. In turn, such a change indirectly affects the change of political order. For instance, the historians, who work in the field of the so-called subordinate classes or oppressed minority groups (women, ethnic minorities, gays and lesbians, etc.) and for whom the history writing is a kind of oppositional political activity (Eva Domanska calls such historiography "rebellious"), indirectly contribute to the improvement of their social standing, acquisition of real political rights and incorporation of these groups of society into authority. The political role of such type of professional historiography manifests itself in the close connection between national history and nation project. It is common knowledge that the so-called scientific historiography came into existence being greatly dependent on the creation of state-nation, and nowadays the research/teaching of history was and, to a large extent, remains the research/teaching of the history of nations ${ }^{6}$.

The historical work can work for a particular political project or its undermining in the form of the so-called replaced knowledge. In such a case, a historian with an intention to promote the achievement of a political aim persuades the reader by drawing historical parallels or making historical allusions to a real and desired political project, about which the historian does not speak directly. The peculiarity of the replaced knowledge lies in the complexity of its "capture": determining its presence is practically impossible as the author's political aspirations are not stated overtly in the text. Thus, the historian may not do it subjectively, and such an intention will be credited to him post factum by himself or the readers and researchers of his works; and vice versa, such type of politicized historiography may be overlooked, even if its creator strove for a completely opposite effect. The fact of a similar type of utilitarian usage of historical analogies is considered to be paradigmatic by Johann Gustav Droysen: striving for German reunification under the auspices of Prussia, the famous scientist criticized the political particuralism of Greek citystates, with a view to politically fragmented Germany, and approved the centralized course of the Macedonian kings Philip II and Alexander the

\footnotetext{
${ }_{6}^{5}$ Е. Доманська. Історія та сучасна гуманітаристика. Київ, 2012. С. 96-97.

${ }^{6}$ The many faces of Clio: cross-cultural approaches to historiography, essays in honor of Georg G. Iggers. New York, 2007. P. 74.
} 
Great, trying to present them as a model for imitation and a prototype of the unifying politics of contemporary for him Prussian state, in his works on history of Hellenism ${ }^{7}$. Some researchers, for instance, believe that this replaced knowledge was practiced by a number of historians in the Soviet times $^{8}$. Notably, it is argued that in his research on the politics of terror of Ivan the Terrible, a famous scientist Stepan Veselovskyi discredited not only detrimental politics of this apologized by Stalin's propaganda Russian monarch but also Stalinist purges ${ }^{9}$.

A thesis about the bias of any professional historian, determined by psychological peculiarities of his work, has already been trivial for a long time. Since the beginning of his work - choice of subject and line of research, till its end - implementation of a certain method of historical representation (rhetorical devices, style, etc.), the historian is entangled in a thick combination of extrascientific dependencies: on his world-view (including political convictions), psychological attributes and specific psychological state, expectations of readers and society as well as people in power in general. At the same time, the majority of professionals accept the idea that the absolute elimination of the influence of a historian's social and cultural "horizon" on his work is a desirable but impossible ideal. "Any history is tendentious, and if it were not tendentious, then no one would write it", spoke ironically about the historical subjectivity Robin G. Collingwood $^{10}$. Karl Popper emphasized the fact that a true historian must not deceive himself, trying to avoid "a selective point of view" (as it is impossible) but "clearly see the relevance to accept any point of view; in order to express it openly and always realize that it is one of the many"11.

Can the "imposition" of historian's political beliefs on the historical "material", which serves as a basis for his text, be regarded as a demonstration of politicized history writing? We believe that the answer is no because in such a case, it is not about wholehearted support of any political power or actions in the present/future but about cognitive patterns

7 Бугай Д. Иоганн Густав Дройзен: открытие эллинизма в немецкой науке об античности. Дройзен И. Г. История эллинизма. История Александра Великого. Москва, 2011. С. 11.

8 Бухараев В.М., Жигунин В. Д. «Замещенное» познание: историческая мысль против моноидеологии (60-80-е гг. ХХ в.). Россия в ХX веке: судьба исторической науки. Москва, 1996. C. 552-563.

9 Дубровский А. Историк и власть: историческая наука в СССР и концепция истории феодальной России в контексте политики и идеологии (1930-е - 1950-е гг.). Брянск, 2005. С. 770.

${ }^{10}$ Колінгвуд Р. Дж. Ідея історії. Київ, 1996. С. 495.

${ }^{11}$ Поппер К. Злиденність історицизму. Київ, 1994. С. 169. 
of the historical topics, interpretations and evaluations, including worldview. Even the most objective historian is not usually free from filling his research with his own political beliefs as at least two research operations the choice of subject and the selection of facts, which will constitute the outline of events of his narrative, - involve selection that is activated by historical representations about important/unimportant, good/bad, which, in turn, are rooted in his system of values, including political. Thus, the best historical research, which fulfills the requirements for scientificity (as it is known, there is no absolute agreement on the canons of scientificity in historical science) - representative source bases, empirically and logically argued conclusions, thoroughly organized references to the sources of information, etc - can contain the author's political proclivities and antipathies. However, accusing such a text of being politicized is baseless because in such case, we must consider almost all historiography as politicized!

Doubtless, the above-mentioned conclusions on what should be regarded and what should not be regarded as "politicized history" partake, to a certain extent, of the ideal model. Often the researcher himself cannot understand where he writes "scientific" history and where - historical politics. Moreover, it is difficult (both for the author and for his readers) to draw a borderline between a consciously tendentious interpretation of the past for the sake of modern political aims and unconscious approval/disapproval of activism of the actors of the past and emotional connection with them (we will repeat one more time that such unconscious peculiarities of research activity are inherent and cannot be eliminated).

\section{How to Treat Politically Engaged Texts of Professional Historians?}

The answer to this question seems obvious, especially to the historian, who has working experience in the context of Soviet historiography. Nonetheless, even in the academic segment, there has not been a unanimous world historical opinion about the attitude towards the political instrumentalization of historiography. A tradition, the representatives of which see sense and purpose of professional historiography in serving the "good", "progressive" political regimes and projects, is long-established and it is not going to leave the agenda of history writing. Respectively, the support of particular political power or political ideology is expressed openly. An interesting thing is, that such an approach was justified at the 
same time when the academic standards of history writing were established - in the "age of history". The famous historians of the 19th century did not avoid defending certain political interests and creating the history of their countries respectively via their works. Illustrative in this regard was an example of France, where the historians François Guizot, Alexis de Tocqueville, Louis-Adolphe Thiers were the key figures of the political arena, who via historical texts advertised their political beliefs and ideological platforms of those political powers, to which they belonged. As it was already mentioned, the classic example of overtly politically engaged history writing was "Prussian" school of historiography, which ideologically supported Lesser Germany. An exponential expression regarding the political dimension of history belongs to Heinrich von Schtreicke, one of its representatives: "As the world goes, during the turbulent years of his existence, the historian has always been called politically uncommitted only in one case: when he was laying in the grave" $" 12$. Another representative Heinrich von Sybel once stated that he had four seventh of a politician and the rest - of a professor ${ }^{13}$. This is how early Soviet historiography looked like, when novices at the historical profession, who called themselves Marxists, considered the usage of history for the justification of current politics to be a normal practice. For instance, in Ukraine, a direction of "national and communist" history writing led by Matvii Yavorskyi appeared. Some of his advocates sincerely stated that the historical facts must be regarded from the point of view of "contemporary revolutionary task" ". Later Soviet historiography did not demonstrate its political orientation so openly but emphasized its supposedly unshadowed scientificity. Ironically, in the historical science of the USSR in 1930-1980s, whose official methodology was "MarxismLeninism", there were few ideological supporters of K. Marx, F. Engels, and V. Lenin as well as historians, who deeply knew and understood the sense of "eternal teaching". A factual ideological basis of historical texts was a political order on behalf of Kremlin's rulers, who were giving corresponding signals. The "court" historians wrapped them in a "MarxistLeninist" paper and sent the messages to the rest of professional historians

\footnotetext{
12 Зашкільняк Л. Сучасна світова історіографія. Львів, 2007. С. 29.

${ }^{13}$ Baár M. Op. cit. P. 6.

14 Яремчук В. «Націонал-комуністичні» концепції в професійній історичній думці радянської України. Історія - ментальність - ідентичність. Випуск IV: Історична пам'ять українців і поляків у період формування начіональної свідомості в XIX - першій половині XX століття : колективна монографія. Львів, 2011. С. 322-329.
} 
and the general public. For this reason, the main keynote of the Soviet historiography about the histories of non-Russian people of the USSR was a thesis about the exceptional meaning of Russian people and their states in their historical destiny, which is absent in both K. Marx and F. Engels, and V. Lenin, but which provided integrative Russian politics of Kremlin in the constituent republics with historical arguments.

Some contemporary historians of other ideological orientations hold similar views on the positive meaning of "ideologically correct" historiography. In particular, according to Franklin Rudolf Ankersmit, "the most persuasive historical works are replete [...] with the best political ideals and values"15. As the Dutch philosopher claims, it will be enough to provide examples of works of such authors as Jacob Talmon, Isaiah Berlin or Karl Friedrich, imbued with the ideals of liberal democracy and outspoken criticism of totalitarian regime, to understand that the subjectivity should not necessarily mean the major flaw of history writing in every situation ${ }^{16}$. Another well-known thinker sees the positive influence of political stands of historians on historiography in the fact that they "can align generated knowledge according to its importance and, at the same time, criticize specific to their profession arbitrariness of scientific research"17.

However, the consciousness of probably the major part of the guild relies on the maxim of valuable neutrality, which was formulated in the works of Leopold von Ranke and Max Weber ${ }^{18}$. One of the "fathers" of professional historiography not only declared a well-known method of writing history "as it happened", but according to Benedetto Croce, "has never deviated from this method and because of this, achieved resounding triumphs: a committed Lutheran, he writes the history of the papacy in the period of Counter-Reformation, and it is favorably accepted by all the Catholic countries; a German, he writes the history of France and does not

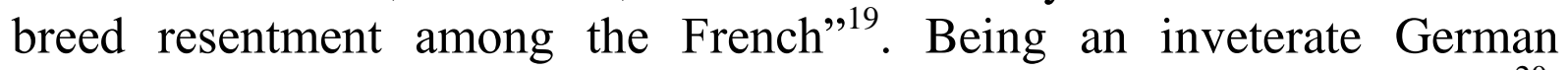
nationalist, who regarded history as a struggle for national survival ${ }^{20}$, M. Weber left behind works, which are an example of scientific logic and

\footnotetext{
15 Анкерсмит Ф. Политическая репрезентация. Москва, 2012. С. 7.

16 Ankersmit F. Pochwala subiektywności. Pamięć, etyka $i$ historia: Anglo-Amerykańska teoria historiografii lat dziewięćdziesiątych (Antologia przekładów). Poznań, 2002. S. 80.

${ }^{17}$ Рюзен Й. Нові шляхи історичного мислення. Львів, 2010. С. 138.

${ }^{18}$ Иггерс Г., Ван Э. Op. cit. С. 143, 193-195.

${ }^{19}$ Кроче Б. Теория и история историографии. Москва, 1998. С. 174.

${ }^{20}$ Иггерс Г., Ван Э. Ор. cit. С. 195.
} 
impartiality. In a concentrated form, the reasons for imperception of the politicized history writing were explained by one of the authors of a recent collective research of famous European scientists on the political usage of history and its misuse: "[...] the relationships between history and politics can turn into a fatal friendship, which offers a reward of public attention and moral dignity; at the same time, a complete independence of historical research and its aspiration for reinterpretation of the past are eliminated" 21 .

Unlike proponents of politicized history, its opponents defend not only the need but also the ability to write texts, which are not connected with the political orders and acquire relatively true historical knowledge. However, a bigger or smaller impact of political agenda on authors, who write historical texts, is not rejected. The historians may successfully resist it due to the made by academic historiography rules and procedures and close control over the history writing on behalf of professionals. For example, Georg Iggers argues, "I understand such a high level, in which history writing comprises ideology, but I believe that it also includes an attempt to refer to the past [...]. The fact that an ideological element is included in every historical perception does not exclude a possibility to reconstruct reality the best possible on the basis of evidence"22.

Speaking about the attitude towards politically partial historiography, an American theorist of history writing Allan Megill, who insists on the relevance and possibility of only free from any interference of today's tasks, including political situation, "critical" historiography, based on a "methodologically justified research" and opposed to a "non-scientific" in a manner of speaking presentist ("affirmative") and directed at the guidance of ("didactic") historiography, adopts a refined Purist stance ${ }^{23}$. He argues that "one of the functions of the historical profession is its constant opposition to political topicality and retrospective research, conducted carefully and thoroughly, disregarding the possible consequences" 24 . Therefore, the above-mentioned historians advocate for the ability of their profession to create independent from political orders knowledge as well as their need to distance from the current political interests of those groups, which they belong to.

\footnotetext{
${ }^{21}$ Sabrow M. The Use of History to Legitimise Political Power: The Case of Germany. Politics of the Past: The Use and Abuse of History. Brussels, 2009. Р. 103.

22 Доманска Э. Философия истории после постмодернизма. Москва, 2010. С. 151, 153.

${ }_{23}^{3}$ Мегилл А. Историческая эпистемология. Москва, 2007. С. 102-103, 109, 111, 131.

${ }^{24}$ Ibid. C. 109.
} 
In the world historiography, there is a specific interpretation of the problem of attitude towards politicized history and the ability of historians to resist the politicization of their research. Philosophers and historians, who fall into the category of the intellectual movement, known as postmodernism, believed (believe) that the historical knowledge a priori contains an ideological component and is an instrument of power. Some of them draw this conclusion from the very nature of the historical text. In the mid-1970s, Michel de Certeau proved that historical narrative has two dimensions: performative and narrative (in other words, it contains the story about the past reality): "[...] historical writing [...], playing on two boards, agreement and signature, performative writing and mirror writing at the same time, [...] acquires the status of "the creator of history" along with "the narrator of stories". In other words, it imposes limitations on behalf of power and [at the same time] provides gaps" ${ }^{, 25}$. The others insist on the social dependence of politicized history writing. Pretty much the most passionate advocate of such views, a "killing machine of history" (as he was called by one British researcher), another British Keith Jenkins argues that historians write history only in order to promote some immediate practical and political interests. In his opinion, the history by professional historians, who are deeply integrated into the social reality, is a stamp of a ruling or one of numerous radical or subversive ideologies of this reality, and all these ideologies are rooted in contemporary politics in the same manner. The texts of historians, who work in official scientific institutions, express their specific financial interests (job positions and good income). "The maxim of judgment", inherent in the ethos of the professional environment, which proves its aspiration for objectivity in scientific research, according to $\mathrm{K}$. Jenkins, in fact, means implicit agreement with the existing regime ${ }^{26}$. For this reason, as this theorist of history writing states, both "big history" (or metanarrative history) and "small history" (in other words, professional, academic) are ideologized and engaged equally, which means that "the history always serves someone". Thus, it is worth "forgetting history", "letting it go" and learning to live new ways of time synchronization ${ }^{27}$.

\footnotetext{
25 Серто М. де. Историографическая процедура. Письмо. URL: http://magazines. russ.ru/nz/2014/3 (access date May 16, 2019).

${ }^{26}$ For the explanation of views of Keith Jenkins, see: Заярнюк А. Постмодернізм про істориків, encore. Український гуманітарний огляд. Київ, 2010. Вип. 15. С. 24-44.

${ }^{27}$ Jenkins K. Życie w czasie, lecz poza historią; życie w moralności, lecz poza etyką. Pamięć, etyka $i$ historia: Anglo-Amerykańska teoria historiografii lat dziewięćdziesiątych (Antologia przekładów). Poznań, 2002. S. 235-236.
} 
Published in 1990-2000s, the works of K. Jenkins provoked sharp polemic, where not only scientific arguments but also defamatory accusations against this scientist of boundless individualism, left-wing posturing and solipsism were mentioned. A reply of another British Richard Evans to the postmodernist skepticism regarding the profession of "traditional" historians was rather persuasive. In response to the philippics of K. Jenkins, R. Evans showed groundlessness of the thesis of his vis-avis that academic historians are a type of ruling elite by providing specific examples in a hit-hitting book "In Defense of History". He also ridiculed another Jenkins's thesis on the compulsory determinism of historians' views ("ideology") by their social standing. Whatever the truth, according to the ironic remark of R. Evans, white historians-males must have been writing only about dead white males; historians who write about vagabonds would be vagabonds themselves, and those who write about criminals would be criminals ${ }^{28}$.

In western historiography, there is another extreme, very optimistic for now, view on the problem of the presence of a political component in the professional history writing, represented, for instance, by a French historian Paul Veyne. He refutes an immanently presentist character of professional historiography, believing that "the ideas [of historians] stem from anything: topicality, fashion, chance, reading of a book in the ivory tower; even more often, they originate from one another and studying of the subject", and the absolute priority of presentism "signifies a simplified view on the intellectual life" 29 . Therefore, as if refuting the famous adage of Paul Valéry about history as "the safest product, which is manufactured by the chemistry of intellect", he states the following, "History is one of the least harmful products that have ever been manufactured by the chemistry of intellect; it neutralizes the values and passions not because it arrives at the truth instead of biased fallacies but because the truth is always disappointing and the history of our Motherland, as well as history of other nations, turn out to be boring very quickly"30.

Let's draw preliminary conclusions. The history of world historiography shows different forms and manifestations of the politicization of historical texts as well as different attitudes to the political instrumentalization of historian's works. Thus, there is a need for more

\footnotetext{
${ }^{28}$ Еванс Р. Дж. На захист історії. Львів, 2008. С. 163-165, 221.

${ }^{29}$ Вен П. Как пишут историю. Опыт эпистемологии. Москва, 2003. С. 104.

${ }^{30}$ Ibid. C. 105.
} 
discrete intelligibility of the term "politicized history". The level of historian's distortions and differences between the representations of the past and the past itself depends on how much politicization is understood, deep, direct or indirect, forced or voluntary. It is impossible to correct the reality in favor of certain political regimes, programs or projects as well as announce the same verdict regarding the political tendentiousness without grounds. The devil, as usual, hides in details.

We tried to show that every form of politicized history described above is characterized by a different level of distortion of the past, thus having a different scientific level and importance in historiography (if regard history writing as a cumulative process of accumulating knowledge about the past). The first form - direct politicization (which was and remains the main flaw of professional history writing in virtually all authoritarian and totalitarian countries) should be rejected in its affiliation with science without any second thoughts. The major drawback of history writing about class, ethnos, nation, race, gender, confession, etc. is a focus only on these phenomena. At the same time, this drawback is a certain advantage as it predetermines deep (but one-way, without considering contexts and their relationships!) study of these phenomena. However, we believe that it is groundless to deny scientificity to such historiography on these grounds as any history writing cannot cover all past reality, thus presenting its bigger or smaller fragment. Finally, the phenomenon of replaced knowledge is interesting because it contains historian's political intentions, does not interfere in the research process and does not contradict the established standards of scientificity as the historical parallels or allusions themselves do not misinterpret the past.

\section{3. (Im)possibility of "Non-Politicized" History Writing}

One of the theses that the author tried to prove above is as follows, non-politicized history writing is not only "theoretically" possible but also the most acceptable/complimentary in the contemporary historical thought and practice of professional historiography. However, we consider the idea of the possibility of the transcendent historical science existence with an apolitical figure of a historian to be an impossible ideal, some kind of scientific illusion. The reason for such skepticism is rather evident: even if they had not been subjectively programmed to achieve certain political aims, historical texts bring political senses irrespective of the author's will. 
In other words, even though non-politicized history writing is a rather ordinary for the historical science thing, historians cannot avoid politicization of their texts by their "audience". A knowledgeable and clever reader will notice a similarity to the ideas of apostles of deconstructionism about the independence of the text from the author and limitless possibilities of its interpretations here. However, unlike Michel Foucault, Jacques Derrida and Yuliia Kristeva, we do not claim a) correctness of such a state of things but just its objective presence and b) absence of a fixed sense, implied by the author, and relevance of all his interpretations in a particular text.

In this connection, first of all, we will mention that if required, the political component can be attributed to virtually any historical text or be ignored in it. In other words, irrespective of the author's subjective intentions, his reader can find a reference to the topical political interests in his work. Here, a need to "activate" "hidden" political senses, in the absence of which the text cannot be considered politically engaged, is fundamental. Attribution of political compulsions becomes especially mundane in times of the rule of instrumentalist ethos in the global culture, which (rule) is diagnosed by the contemporary sociologists ${ }^{31}$. We have a social reality, in which human intellectual and cultural activity is perceived, first of all, in the light of its practical, including political, value, and it is unlikely that something can be done about it! Apart from that, if to talk only about the Ukrainian situation, quite a few intellectuals point out at the seriousness of political stakes in the Ukrainian history, which, from our perspective, trigger its utilitarian interpretation.

Evidently, it is more difficult to see political interest in those works, which research microprocesses. This is much easier to do, first of all, in the summaries of national histories and histories of regions or parts of the world, which contain certain explanatory schemes and judgments that can be interpreted as directed at the support of this or that world order (for example, Eurocentrism, world communist revolution, globalism etc.). Besides, the higher level of conceptualization of historical material is, the easier it is to accuse such broad historical structures of political bias. For this reason, if "new imperial history" is an adequate instrument for explaining heterogeneity and ambivalence of imperial formations of the past for some historians, it is an instrument for fueling ambitions of the

\footnotetext{
${ }^{31}$ Furedi F. Gdzie się podziali wszyscy intelektualiści? Lublin, 2008. S. 8-9.
} 
world superpower, supporting neocolonialism and neo-imperialism for the others. "Transnational history" not only challenges the drawbacks of national history, especially its exclusive and homogenized interpretation but also creates a "scientific" basis for such a "western" in its core phenomenon as globalization as well as provides supranational political formations (European Union in particular) with a common image of history. Likewise, the proponents of post-colonial theory see in it a thoroughly analyzed critique and deconstruction of western stereotypes about "the East", while critical researchers see only an ideological product, used as a basis for politics of multiculturalism, which contains a new, now "Eastern", stereotype of "the West" and, in this way, does not differ from a western "model". Furthermore, continental history writing itself (with a rational methodology and anthropocentrism) can be interpreted as a political instrument, invented by "the West" to colonize nations that do not regard history as their way of treating the past. However, in case of appropriate attention even to the "microhistorical" or "anthropologically oriented" texts, whose methodology is based on the refutation of metanarratives as the means of legitimization, it is possible (although quite difficult and usually groundless) to find a useful for "connecting hearts" idea. For example, in the character of a country intellectual and a selftaught heretic, Menocchio from "The Cheese and the Worms" of Carlo Ginzburg - a classic microhistorical and "anthropological" work - a nationally worried Italian can see a worthy son of the Italian land, a proof of chief virtues of his fellow countrymen even in the common people far back in the mists of ancient time.

\section{CONCLUSIONS}

Therefore, we regard the politicized history as such historical representation, which has a purpose of supporting (voluntarily or forcefully, directly or indirectly) actual or desired political order. Insertion of historians' political proclivities in their texts without a clear sense of purpose "to correct" today's world or the future order cannot be considered politicization of history for several reasons. Firstly, the insertion of the Author's values (including political) in the text depends on the nature of the research process itself. Secondly, in this case, the meaning of the term "politicized history" is lost. 
Among the majority of professionals, there is an unwritten agreement on the prohibition of submission of history to the political tasks. However, there are some solid refusals of the positive role of the political component of the historian's consciousness and the historical knowledge for the inspiration of socially responsible (or useful to the society) texts and formation of just social order. Extreme views on the connection between professional historiography and politics also rely on certain arguments: the postmodernist vision of it as an ideological in its essence discourse, directed at the support of ruling or oppressed political powers, and denial of significant dependence of historiography on the present day and today's tasks. When it comes to the key in this regard thesis of this article, it states that there are different forms of politicized history and they have different relations to the historiography, which is commonly believed to be scientific. The politicization of the historical text itself does not necessarily confirm the loss of connection between such a text and science.

Among the proponents of history as a free from political tasks knowledge, the certainty of the ability to exclude the political ideals of the historians themselves as well as completely eliminate the current politics from historical texts prevails. However, as unfortunate as it is, the historian's abilities to keep control over texts of the past, which he produces and which are free from civil interests of the present day, are limited, as the results of his work come into the view of not only scientific but also political broadcast as well as political actions and projects without his permission, thus becoming politically engaged. It makes historians particularly attentive to the subjective moments of their own works and, at the same time, open to criticism, including both tactless and inadequate criticism. They, as usual, should strive for the Truth. However, for this, they should not only control their own political ideals and proclivities towards existing political powers but also be aware that their works will not be necessarily interpreted the way they want it. If the historian wants his text to be read absolutely correctly, he should not hide his political beliefs or claim his political neutrality but make them open to the public. It will not only give an opportunity to determine the level of the author's engagement but also "save" his creation from political interpretations, which were not subjectively included by the author. 


\section{SUMMARY}

The article is dedicated to the problem of politicization of professional history writing. Through the lens of the world historiographic tradition, such components of the problem as the definition of the category "politicized history", methods and meanings of politicization of history writing, the possibilities and obstructions of history writing from the nonpolitical perspective, were analyzed. In the author's opinion, the politicized history should be regarded as such historical representation, which has a purpose of supporting (voluntarily or forcefully, directly or indirectly) actual or desired political order. Insertion of historians' political proclivities in the historical representations without a clear sense of purpose "to correct" the today's world or the future order cannot be considered politicization of history as the historians' values are incorporated in the research process itself, and in this case, any professional historiography should be considered politicized. The article showed that there are various forms of politicized history and that they have different relations to historiography, which is commonly believed to be scientific. The politicization of the historical text itself does not necessarily confirm the loss of its connection with science. The author proves that historians are capable of excluding their political ideals and eliminating the current politics from historical research. On the other hand, the historians' abilities to keep control over texts of the past, free from civil interests of the present day, are limited as the results of their professional work (scientific texts) come into the view of not only scientific but also political broadcast as well as political actions and projects without their permission, thus becoming politically engaged. With this respect, nonpoliticized history writing is impossible.

\section{REFERENCES}

1. Ankersmit F. Pochwala subiektywności. Pamięć, etyka i historia: Anglo-Amerykańska teoria historiografii lat dziewięćdziesiatych (Antologia przekładów). Poznań, 2002. S. 55-84.

2. Baár M. Historians and Nationalism. East-Central Europe in Nineteenth Century. New York, 2010. 353 p.

3. Berger S. Rising Like a Phoenix...The Renaissance of National History Writing in Germany and Britain since the 1980s. Nationalizing the Past: Historians as Nation Builders in Modern Europe. New York, 2010. P. 426-451. 
4. Furedi F. Gdzie się podziali wszyscy intelektualiści? Lublin, 2008. $167 \mathrm{~s}$.

5. Janowski M. Postmodernizm przed modernizmem. Historia - dziś. Teoretyczne problemy wiedzy o przeszłości. Kraków, 2014. S. 37-57.

6. Jenkins K. Życie w czasie, lecz poza historią; życie w moralności, lecz poza etyką. Pamięć, etyka i historia: Anglo-Amerykańska teoria historiografii lat dziewięćdziesiatych (Antologia przekładów). Poznań, 2002. S. 235-284.

7. Sabrow M. The Use of History to Legitimise Political Power: The Case of Germany. Politics of the Past: The Use and Abuse of History. Brussels, 2009. P. 97-103.

8. The many faces of Clio : cross-cultural approaches to historiography, essays in honor of Georg G. Iggers. New York, 2007. $484 \mathrm{p}$.

9. Анкерсмит Ф. Политическая репрезентация. Москва, 2012. $288 \mathrm{c}$.

10. Бугай Д. Иоганн Густав Дройзен: открытие эллинизма в немецкой науке об античности. Дройзен И. Г. История эллинизма. История Александра Великого. Москва, 2011. С. 5-16.

11. Бухараев В.М., Жигунин В. Д. «Замещенное» познание: историческая мысль против моноидеологии (60-80-е гг. XXв.). Россия в ХХ веке: судьба исторической науки. Москва, 1996. C. 552-563.

12. Вен П. Как пишут историю. Опыт эпистемологии. Москва, 2003. 394 c.

13. Доманска Э. Философия истории после постмодернизма. Москва, 2010. 400 с.

14. Доманська Е. Історія та сучасна гуманітаристика. Київ, 2012. 264 c.

15. Дубровский А. Историк и власть: историческая наука в СССР и концепция истории феодальной России в контексте политики и идеологии (1930-е - 1950-е гг.). Брянск, 2005. 800 с.

16. Еванс Р. Дж. На захист історії. Львів, 2008. 296 с.

17. Зашкільняк Л. Сучасна світова історіографія. Львів, 2007. 312 c.

18. Заярнюк А. Постмодернізм про істориків, encore. Украӥнський гуманітарний огляд. Київ, 2010. Вип. 15. С. 24-44. 
19. Иггерс Г., Ван Э. Глобальная история современной историографии. Москва, 2012. 432 с.

20. Колінгвуд Р. Дж. Ідея історії. Київ, 1996. 615 с.

21. Кроче Б. Теория и история историографии. Москва, 1998. 192 c.

22. Мегилл А. Историческая эпистемология. Москва, 2007. 480 с.

23. Поппер К. Злиденність історицизму. Київ, 1994. 192 с.

24. Рюзен Й. Нові шляхи історичного мислення. Львів, 2010. 358 c.

25. Свобода у историков пока есть. Во всяком случае - есть от чего бежать: беседа Кирилла Кобрина с Павлом Уваровым. URL: http:// magazines.russ.ru/nz/2007/55/sb5.htm (access date May 16, 2019).

26. Серто М. де. Историографическая процедура. Письмо. URL: http://magazines. russ.ru/nz/2014/3 (access date May 16, 2019).

27. Яремчук В. «Націонал-комуністичні» концепції в професійній історичній думці радянської України. Історія - ментальність ідентичність. Випуск IV: Історична пам'ять украӥнців і поляків у період формування національної свідомості в XIX - першій половині ХХ століття : колективна монографія. Львів, 2011. С. 322-329.

\section{Information about the author: Yaremchuk V.P.,} Ph.D hab. (History), Professor, Professor at the Department of History, The National University of Ostroh Academy 2, Seminarska St., Ostroh, Rivne Oblast, 35800, Ukraine 


\section{NOTES}


NOTES 
Publishing house "Liha-Pres"

9 Kastelivka str., Lviv, 79012, Ukraine 44 Lubicka str., Toruń, 87-100, Poland

Printed by the publishing house "Liha-Pres"

Passed for printing: August 30, 2019.

A run of 150 copies. 